\title{
SHAKESPEARE PROBLEMS
}

Edited by A. W. POLLARD छ J. DOVER WILSON

\section{THE 'BAD' QUARTO OF HAMLET}




\begin{abstract}
CAMBRIDGE
UNIVERSITY PRESS

LONDON: BENTLEY HOUSE

NEW YORK, TORONTO, BOMBAY

CALCUTTA, MADRAS: MACMILLAN

TOKYO: MARUZEN COMPANY LTD
\end{abstract}

All rights reserved

PRINTED IN GREAT BRITAIN 


\title{
The 'BAD' QUARTO of HAMLET
}

A CRITICAL STUDY

\author{
by \\ GEORGE IAN DUTHIE \\ M.A., Ph.D. \\ Carnegie Research Scholar \\ (1937-40)
}

\section{CAMBRIDGE}

AT THE UNIVERSITY PRESS

I 94 I

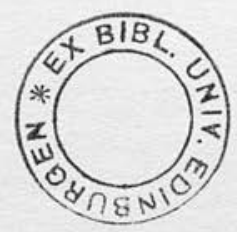




\section{TO}

J. D. W. 


\section{CONTENTS}

Prefatory Note

PAGE vii

Foreword by w. w. GREG ix

Introduction I

I. Good and Bad Quartos I

II. Good Quartos

III. Bad Quartos

IO

Piracy by Stenography

I 2

Memorial Reconstruction

First Sketches or Debased Versions of the Good Texts?

Chapters

I. The External Evidence for a pre-Shakespearian Hamlet

II. The External Evidence for a Shakespearian First Draft

III. The First Quarto of Hamlet: the Main Controversy

IV. Blank Verse Peculiar to QI

V. The "Marcellus Theory"

VI. The Composite Nature of the Copy for QI I44 
Chapters

VII. What Stage of the Hamlet Text-History

Underlies QI ?

PAGE I 8 I

I. The Kyd Quotations in QI I $\mathrm{I}$

II. Hamlet's Voyage 186

III. The Character of the Queen $\quad$ I93

IV. The Position of the "Nunnery" Scene

V. The Name "Corambis"

220

VI. Hamlet's Age

227

VII. Hamlet's Directions to the Players: the Clown

VIII. Der Bestrafte Brudermord

IX. The First Quarto: Conclusions 


\section{PREFATORY NOTE}

I should like to record my gratitude to the Carnegie Trust for the Universities of Scotland, under whose Research Scheme this work has been written; to Professor J. Dover Wilson, to whom I am deeply indebted for encouragement and assistance given freely and generously at all times; and to Dr W. W. Greg, who has kindly read the book in manuscript, made a number of most useful suggestions, and written a Foreword.

G. I. D.

University of Edinburgh 
explain them may open the door to all manner of critical extravagance. I can only say that in this as in other matters Dr Duthie seems to me to keep his head remarkably well.

The most important section of the work is probably Chapter IV, on "Blank Verse Peculiar to Qr", in which it is argued that the passages of smooth but pedestrian verse parallel in thought but not in expression to the genuine text, far from being remains of an early Hamlet, are the original composition of the reporter. While not all the parallels and echoes found by Dr Duthie are necessarily pertinent, he conclusively establishes his thesis that the passages in question are built up out of verbal reminiscences, mainly of various and scattered portions of the full text, partly of other Shakespearian and non-Shakespearian plays. There is, I think, no doubt that it is in this manner that we should account for those fragments of $\mathrm{K} y$ dian verse that we find embedded in the text, rather than by assuming survival from an earlier Hamlet of which $\mathrm{K}$ yd may or may not have been the author. To have demonstrated this in detail is no inconsiderable service to the study of the play.

There is one chapter which I think some readers may find less convincing than the rest. Discussing "The Composite Nature of the Copy for QI" Dr Duthie argues that the reporter's reconstruction underwent revision by another hand. The argument contains some of his most acute observation and analysis, but does not appear to lead inevitably to its conclusion. That there has been revision in the way of afterthoughts may be conceded; but so far as I can see there is no evidence for supposing that this was the work of a second hand, and some for supposing that it was not. It looks as though in this section of his work, which stands quite apart from the rest and in no way affects his general argument, Dr Duthie had succumbed to that excess of ingenuity we sometimes associate with his distinguished teacher, but from which his own work is elsewhere remarkably free. It is almost as 
though he had said to himself: "I have thoroughly demolished the elaborate structure erected with such superabundant subtlety by Professor Dover Wilson, but just to show that I am not blind to the beauties of his method, I will try what I can do in the same line myself"!

I think that perhaps the most difficult part of the whole problem is the position of the Bestrafte Brudermord. I have no clear ideas of my own on the subject and should hesitate to endorse those of any other critic. But I have no hesitation in recommending to careful consideration the suggestions put forward by Dr Duthie. The question bristles with difficulties. That there is a fundamental connection between the 1603 text and the Brudermord can hardly be doubted, yet the latter is certainly not derived from the former. I must content myself with a warning against the assumption that the version taken abroad by the English actors was inferior to that which we find in the First Quarto. For all I can see it may have been an even superior version, and the degradation of the extant text may be entirely due to theatrical conditions in Germany.

It is not to be supposed that Dr Duthie's monograph will be accepted as offering a final solution of the problem. It is hardly to be desired that it should. But I do think that it will prove an important step towards such a solution, and hope that it may, even in these days, arouse further interest in the subject. 


\section{INTRODUCTION}

\section{GOOD AND BAD QUARTOS}

The attitude of twentieth-century scholarship to Shakespearian textual problems has been conditioned by the vitally important work of Professor Alfred W. Pollard, ${ }^{\mathrm{I}}$ who has once and for all classified the Quarto editions in two distinct groups, termed respectively "good" and "bad" Quartos.

In the address "To the great Variety of Readers", prefixed to the Folio of 1623 over the names Iohn Heminge and Henrie Condell, it is stated that Shakespeare's "Friends" have so published his works

as where (before) you were abus'd with diuerse stolne, and surreptitious copies, maimed, and deformed by the frauds and stealthes of iniurious impostors, that expos'd them: euen those, are now offer'd to your view cur'd, and perfect of their limbes; and all the rest, absolute in their numbers, as he conceiued them.

Professor Pollard finally exposed as a misinterpretation of this passage the view that Heminge and Condell were condemning as "stolne and surreptitious copies" all the Shakespearian Quartos which had previously appeared.

We meet with this misinterpretation first in Pope, who states that Heminge and Condell "declare, that all the other editions were stolen and surreptitious, and affirm

I Shakespeare Folios and 2uartos (1909): King Richard II, a New 2uarto (1916): Shakespeare's Fight with the Pirates (Ist ed. 1917: Cambridge Shakespeare Problems Series, 1920, reprinted 1937): The Foundations of Shakespeare's Text (British Academy Shakespeare lecture, 23 April 1923; reprinted in Aspects of Shakespeare, 1933, pp. 1-22): Shakespeare's Text (pp. 263-86 of A Companion to Shakespeare Studies, ed. Granville-Barker and G. B. Harrison, 1934).

D в 0 
theirs to be purged from the errors of the former'. I A similarly derogatory view of all the early Shakespearian Quartos was taken by Theobald, who in the preface to his edition ${ }^{2}$ points out that in Shakespeare's time an author sold his plays to actors who thereupon became the sole proprietors of these plays, which they kept unpublished in their own interests. "Hence", continues Theobald, "many pieces were taken down in short-hand and imperfectly copied by ear from a representation; others were printed from piecemeal parts surreptitiously obtained from the theatres, uncorrect, and without the poet's knowledge. To some of these causes we owe the train of blemishes that deform those pieces which stole singly into the world in our author's life-time."3 Again, in his Proposals for Printing the Dramatick Works of William Shakespeare (I756), ${ }^{4}$ Johnson passes the same judgement on all the Shakespearian Quartos, which he regarded as having been "printed... without the concurrence of the author, without the consent of the proprietor, from compilations made by chance or by stealth out of the separate parts written for the theatre: and thus thrust into the world surreptitiously and hastily, they suffered another depravation from the ignorance and negligence of the printers." 5

Capell was more enlightened. In the introduction to his edition $(1768)^{6}$ he actually divided the Quartos published during Shakespeare's lifetime into two distinct groups. One of these groups contained the following Quartos: Henry $V$ (1600), The Troublesome Raigne of Iohn King of England (1591), The Merry Wives of Windsor (1602), and The

I Preface to Shakespeare (Ist ed. 1725, 2nd ed. 1728). I quote from Boswell's edition of Malone's Shakespeare (1821), vol. I, p. I2.

2 ist ed. 1733 , 2nd ed. 1740.

3 Boswell's edition of Malone's Shakespeare, vol. I, pp. 32-3.

${ }^{4}$ Easily accessible in Walter Raleigh's Fohnson on Shakespeare (Oxford Miscellany, igo8).

5 Fohnson on Shakespeare, p. 2.

${ }^{6}$ See Boswell's edition of Malone's Shakespeare, vol. I, pp. I2 I ff. 
Taming of A Shrew (1594). These four texts he refers to as being "no other than either first draughts, or mutilated and perhaps surreptitious impressions of those plays, but whether of the two is not easy to determine". He is quite sure that The Troublesome Raigne is a first draft; and he also classifies The First Part of the Contention (1594) and The True Tragedie of Richard Duke of Yorke (1595) as first drafts. To these six plays he adds the first Quarto of Romeo and Fuliet (1597). Thus we have a group of eight ${ }^{\mathrm{I}}$ Quartos, regarded by Capell as either first sketches or spurious impressions. The other Shakespearian Quartos are placed in a distinct group; ${ }^{2}$ these Capell believed to depend on "the poet's own copies, however they were come by". 3 Capell, too, seems to have considered it possible that Heminge and Condell meant to assail as "stolne and surreptitious" all the Quartos issued up to I623; so he admits of the fourteen texts which he groups together that "it may be true that they were 'stolne'; but stoln from the author's copies, by transcribers who found means to get at them". 4

Malone's hypothesis is similar to that of Capell. In his preface of 1790 he declared that Heminge and Condell represented all the Shakespearian Quartos before 1623 as mutilated and imperfect; "but this was merely thrown out to give an additional value to their own edition, and is not strictly true of any but two of the whole number; The Merry Wives of Windsor, and King Henry V.5 With respect to the other thirteen copies, though undoubtedly they were

I Seven plays, but eight Quartos, since The Troublesome Raigne was published in $159 \mathrm{r}$ in two parts each occupying a quarto volume.

2 Thirteen Quartos published during Shakespeare's lifetime, and Othello (1622).

3 Boswell, vol. I, p. 127.

4 Ibid.

5 Later (ibid. p. 207 , note) Malone refers to the first Quarto of Romeo and Fuliet as an "imperfect sketch" which however "furnishes many valuable corrections of the more perfect copy of that tragedy in its present state, printed in 1599 ". 
all surreptitious, that is, stolen from the playhouse, and printed without the consent of the author or the proprietors, they in general are preferable to the exhibition of the same plays in the folio; for this plain reason, because... the editors of the folio... printed the greater part of them from the very copies which they represented as maimed and imperfect, and frequently from a late, instead of the earliest edition."I

The work of Professor Pollard has finally done away with the idea that Heminge and Condell were attacking all the Quartos as piracies. They were condemning a certain number of Quartos, which are undoubtedly spurious ${ }^{2}$ - the first Quarto of Romeo and Fuliet, the Quartos of Henry $V$ and The Merry Wives of Windsor, and the first Quarto of Hamlet. These Professor Pollard segregated as "bad" Quartos. He then proceeded to show that in the case of any of the other Quartos, labelled "good" Quartos, there is a high probability that it was printed from the authentic prompt-book, and further that there is a high probability that what was used as the prompt-book was in fact the author's autograph.

I Boswell, vol. I, p. 203.

2 Tycho Mommsen seems to have understood the true implications of Heminge and Condell's preface. In the Prolegomena to his parallel-text edition of the first two Quartos of Romeo and Fuliet ( 1859 ) he mentions the evidence provided by Heywood for the existence of the practice of pirating plays by stenography. He then proceeds (p. ${ }_{5} 8$ ): "Auf eben dieselben (i.e. shorthand reports), aber nicht auf die rechtmässigen und vollständigen Quartausgaben der Shakespeare'schen Stücke bezieht sich das was Heminge und Condell in ihrer Vorrede von 'zusammengestohlenen und erschlichenen Ausgaben, verstümmelt und verunstaltet durch die Prellerei betrügerischer Nachdrucker' sagen." He does not specify here which are the bad and which the good Quartos. It appears from p. I59 that he regards at any rate the first Quartos of Romeo and Fuliet and Hamlet, and the Quartos of The First Part of the Contention and The True Tragedy of Richard Duke of York, as spurious texts. 


\section{GOOD QUARTOS}

Professor Pollard gave Shakespearian scholarship a new confidence, infusing into it a new spirit of optimism. Previously the "depravities" of the Quartos had seemed a matter for lamentation; Professor Pollard showed that the numberless errors and misprints in the "good" Quartos may themselves be valuable bibliographical clues which may lead us straight to Shakespeare's own manuscript.

Hand in hand with Pollard's work in this connection goes Sir Edward Maunde Thompson's investigation of the three pages of the manuscript of Sir Thomas More written by the hand now designated $\mathrm{D}$, and his claim that this is the hand of Shakespeare himself. ${ }^{I}$ It is at least virtually certain that Shakespeare wrote a similar hand. This has been conclusively corroborated by Professor J. Dover Wilson's analysis of the misprints and peculiar spellings in the Shakespearian "good" Quartos. ${ }^{2} \mathrm{He}$ has discovered numerous misprints which are clearly explicable as arising from the misreading of handwriting resembling that of Hand D in the manuscript of More $:{ }^{3}$ and he has also found certain abnormal spellingscommon to Shakespearian "good" Quartos and the three relevant pages of Sir Thomas More. The significant point is, then, that we may regard it as extremely probable that behind any given "good" Quarto

I See Shakespeare's Handwriting (1916), and Shakespeare's Hand in "Sir Thomas More" (1923), pp. 57-1 12.

2 Shakespeare's Hand in "Sir Thomas More", pp. I1 $3-4 \mathrm{r}$.

3 Professor Pollard does not contend that all the "good" Quartos were necessarily printed from Shakespearian autographs, but only that in any given case there is a reasonable a priori assumption that this was so. But even if a "good" Quarto was printed from a transcript of the original, the autograph still underlies the Quarto, two stages removed instead of one. And as Professor Dover Wilson points out (op. cit. p. II 3). "it is exceedingly unlikely that a copyist would obliterate all traces of Shakespeare's penmanship in making his transcript". The position is not essentially different. 
there lies a Shakespearian manuscript; and the only significant amendment which has been made to Professor Pollard's thesis leaves this conclusion intact. Dr R. B. McKerrow argues against the view that the compositors employed on the "good" Quartos had prompt-copy before them. ${ }^{\mathbf{I}} \mathrm{He}$ compares the standard of the printing of these texts with that of contemporary non-dramatic texts, and shows that the latter present conditions incomparably better than the former. The frequency of error in the "good" Quartos is therefore to be attributed to difficult copy rather than to incompetence in the printing-house. Dr McKerrow reminds us that prompt-copy must necessarily have been clearly legible, since repertory companies need a good deal of prompting. And he makes another point of great importance. Professor Pollard had taken short imperative stage-directions, and the appearance of actors' names instead of those of the relevant characters, to indicate the use of prompt-copy by the compositor. ${ }^{2}$ But it must be remembered that Shakespeare was writing with a particular company of actors in mind; he was a practical man of the theatre, and he wrote with performances in view. He himself might therefore have been responsible for the type of stage-direction in question.

One of the most important points raised by $\mathrm{Dr}$ McKerrow is that where actors' names appear in stagedirections in a text printed from a prompt-book, we should expect these to occur in addition to those of the characters they played, as a gloss. 3 Thus, in Believe as You List we find the directions "Ent: Lentulus: Mr Rob: with a letter" and "Ent: Demetrius-Wm. Pattrick". In the Wild Goose Chase we have "Enter Leuerduce, alias Lugier, Mr Illiard" (III i). In The Two Noble Kinsmen

I The Library, 4th series, vol. XII (193I-2), pp. 253-75: "The Elizabethan Printer and Dramatic Manuscripts."

${ }^{2}$ See Shakespeare's Fight with the Pirates, pp. 64-6.

3 Op. cit. pp. $271-2$. 
ACTORS' NAMES IN GOOD QUARTOS 7

(IV ii) there occurs the direction "Enter Messenger. Curtis"; and in the first part of Antonio and Mellida (rv i) "Enter Andrugio, Lucio, Cole and Norwood". This type of stage-direction is indicative of derivation from a prompt-book. But the substitution of an actor's name for that of the character he plays is another matter. We hardly expect a prompter to strike out the name of the character when inserting the name of the actor for his own guidance; and since Shakespeare wrote with his own company in mind he may easily have used an actor's name occasionally in his own manuscripts.

Consider one famous example. In Much Ado About Nothing Dogberry and Verges appear in four scenes, viz. III iii, III v, IV ii, and v i. In the third of these the names of Kemp and Cowley are substituted for those of Dogberry and Verges. The Quarto and the Folios give Dogberry's first speech in this scene to "Keeper"; his speech at line 4 is assigned to "Andrew", and that at lines I4-I 5 to Keeper again (this time abbreviated). Otherwise Dogberry's speeches are assigned to Kemp, and those of Verges to Cowley. A favourite explanation is that "Keeper" is an erroneous expansion of a contraction of Kemp's name, and that "Andrew" was a nickname of Kemp, who had often played the part of "Merry Andrew". However this may be, it seems most probable that it was Shakespeare himself who was responsible for these speech-headings. The parts of Dogberry and Verges are so lifelike, says Dr McKerrow, ${ }^{\mathrm{I}}$ because Shakespeare was thinking of Kemp and Cowley in these parts. Professor H. D. Gray builds up a very attractive hypothesis: ${ }^{2}$ Shakespeare first conceived the two characters as parts for Kemp and Cowley; the crucial trial-scene (Iv ii) was the first of their scenes which he composed. He did not at first know what he was going to call the characters; after a momentary hesitation with the

I Op. cit. p. 275 .

2 Modern Language Revierw, vol. xxv (1930), pp. 263-4. 
general "Keeper", and the name "Andrew" which he at once discarded, he contented himself with temporarily using the actors' own names. At some time after he had completed this scene, but before he composed the other three, he hit upon names which pleased him. If this is sound it is clear that Shakespeare's autograph underlies the text of this play, and also that Shakespeare did not compose a play straight on from beginning to end. He composed the third Dogberry-Verges scene before the first two. In any case, however, it is quite incredible that a book-holder should, in the third scene involving Dogberry and Verges (and in it only), carefully cancel all the speech-assignations to these characters and substitute the names of Kemp and Cowley. These names must have stood in the author's manuscript.

Professor Pollard admits that a dramatist might "if he were familiar with the theatre... use the same technical language as a prompter", and that "the playwright would be almost as likely as the prompter to substitute the name of the actor for whom a part had been written for that of the part itself". But he proceeds: "If the author's manuscript became the prompt-copy, whether any given direction was made by author or prompter is all one." ${ }$ The conclusion of Dr McKerrow's contribution to this subject is, however, that it is unlikely that normally the author's manuscript became the prompt-copy; but after the prompt-copy had been prepared (on the basis of a transcription of the author's manuscript), the autograph itself remained, and was subsequently used as "copy" for authorized editions. ${ }^{2}$ Thus the most important part of Professor Pollard's contention remains - that the copy for any given "good" Quarto may in a given case have been the author's own manuscript.

In an article published in the Review of English Studies

I Shakespeare's Fight with the Pirates, pp. 63-4.

2 In his Manuscript of Shakespeare's "Hamlet" (1934) Professor Dover Wilson shows that this was so in the case of that play.

in

ce

Ir

in

Cc

$\mathrm{ab}$

va

is

$L$,

M

we

a 1

wi

mi

$\mathrm{C}_{i}$

as

of

att

tes

to

Co.

pri

ex]

no

$\mathrm{T}]$

po:

in

thi

I

2

Niz

Tit

3

She

mer

scel

apr 
in $1935^{1}$ Dr McKerrow suggested another indication that certain texts were printed from the author's manuscript. In some Shakespearian texts the names of all the characters in stage-directions and speech-headings remain essentially constant in form, the only differences being in the matter of abbreviation: but in other texts the designations sometimes vary-for example, in $Q_{2}$ Romeo and Fuliet Lady Capulet is variously referred to as Wife, Old La., Capu. or Ca.Wi., La., Mother (or abbreviations), Lady of the house. ${ }^{2} \mathrm{Dr}$ $\mathrm{McK}$ errow suggests that texts exemplifying this peculiarity were probably printed from the author's manuscript. It is a mark of the dramatist himself "who is perfectly familiar with his characters as characters, and who from moment to moment sees them in different aspects". When Lady Capulet is speaking to Capulet she is naturally thought of as "Wife"; when she is speaking to Juliet she is thought of as "Mother", and so on. Such distinctions, easy to attribute to an author in the heat of composition, would tend to confuse a busy prompter and would not be likely to be characteristic of a prompt-book. Texts which do not contain this characteristic may or may not have been printed from a fair transcript: a transcriber might be expected to normalize the designations, but the author need not be supposed to have varied them in every play he wrote. ${ }^{3}$ The great value of this article is that it gives grounds for supposing that some of the authentic Shakespearian texts were in fact set up from Shakespearian manuscripts: and again this is in essential agreement with Professor Pollard's position.

I Vol. xI, pp. 459-65.

2 Plays with such variations are Comedy of Errors, Midsummer Night's Dream, Love's Labour's Lost, All's Well, Merchant of Venice, Titus Andronicus.

3 In some cases there is independent evidence that a genuine Shakespearian text was printed from a transcript, e.g. F I Two Gentlemen and Merry Wives, where all the characters who appear in a given scene are named at the beginning of that scene whether they are to appear at once or not. 


\section{BAD QUARTOS}

It is theoretically possible to suppose that someone connected with a company of actors might surreptitiously copy the prompt-book of a play and sell his transcript to a publisher. ${ }^{I}$ This would be piracy; yet the published text would, if the scribe were efficient, present a sound version of the play as acted. There is thus no necessary relation between the legality or illegality of a publication and the quality of the text which it contains. It is, however, difficult to imagine such a theft as practically possible. The work of transcription would take time, and detection would be virtually certain.

In their address "To the great Variety of Readers", it is of a number of surreptitious editions which contain mutilated and deformed texts that Heminge and Condell complain. In other words, they complain of what we should call "reported" texts, and it is with these that we are here concerned.

We must at the outset be quite sure of what we mean by a "reported" text. The best definition of "reporting" has been given by Dr W. W. Greg, ${ }^{2}$ who uses the term to denote "any process of transmission which involves the memory no matter at what stage or in what manner". Thus the term covers several different methods of transmission, for the memorial element may be involved at one or more of several stages. For example, in the case of an edition based on a stenographic report of one or more performances of a play, no matter how faithful to the performances the shorthand notes may be, the text is still separated from the -authentic version as contained in the official prompt-copy by the memories of the actors. Again, when an actor

I Cf. the theories of Capell and Malone supra.

"See Two Elizabethan Stage Abridgements: "The Battle of Alcazar" and "Orlando Furioso" (Malone Society Publications, extra volume, 1922), pp. $25^{6-9}$. 
dictates a play or a portion of a play to a scribe, without assistance from any written "part", the resultant text is a reported text. And so on.

Since Professor Pollard's segregation of the first Quartos of Romeo and Fuliet and Hamlet and the Quartos of Henry $V$ and The Merry Wives of Windsor as "bad" Quartos, this class of text has received much critical attention. Two very important developments have taken place. First, it has been realized that this category is not limited to four Shakespearian Quartos; various critics have enlarged it by the inclusion of other dramatic texts, Shakespearian and non-Shakespearian. ${ }^{\mathrm{I}}$ Secondly, it has been realized that some "bad" Quartos give texts which are memorial reconstructions, made, for provincial performance, by actors who had previously taken part in the plays concerned but who no longer had access to the promptbooks. The notion, for long widespread, that pirated editions of plays were in general to be accounted for as based on the notes of stenographers sent to performances by unscrupulous publishers has given way to the view that

' For a summary see Leo Kirschbaum's Census of Bad 2uartos (Rervierw of English Studies, vol. xIv (1938), pp. 20-43). The following editions are listed as "bad": Romeo and fuliet Q I 597; The Merry Wives $Q$ r602; Henry V Q I600; Hamlet $Q$ I603; Pericles $Q$ I609 (not in Ff. $\mathrm{r}, 2$ : included in $\mathrm{F}_{3}$, 2nd issue); The First Part of the Contention Q 1594 (a "bad" Q of 2 Henry VI); The True Tragedy of Richard Duke of York Q 1595 (a "bad" $Q$ of 3 Henry VI); King Lear Q 1608 ; Richard III Q 1597 ; the "Parliament Sceane" in $Q_{4}$ Richard II, 1608 (i.e. IV i I 54-3I 8); Orlando Furioso (Greene) Q i 594; The Massacre at Paris (Marlowe), octavo, undated; If You Know Not Me You Know Nobody, Part I (Heywood) Q $1605 ;$ A Knack to Know an Honest Man $Q$ 1596; The Famous Victories of Henry the Fifth $Q$ 1598; Sir Thomas Wyatt (Dekker, Chettle, Wentworth Smith, and Webster) Q r607; The True Tragedy of Richard III Q $1_{594}$; Edward I (Peele) Q 1593 ; Fair Em Q circa 1593; George a Greene Q 1 599; Philaster (Beaumont and Fletcher) $Q_{1}{ }_{1620}\left(Q_{2}, 1622\right.$, is a "good" $\left.Q\right)$. Possibly also to be included is the first Quarto of $A$ Maid's Tragedy. Kirschbaum refuses to admit The Taming of $A$ Shreww as a "bad" Quarto: in this I disagree with him. 
at least a large proportion of the extant Elizabethan and Jacobean "bad" texts are in fact memorial reconstructions. There is external evidence that stenographic piracy was a known practice, at any rate in the first part of the seventeenth century; modern scholarship differentiates, therefore, between stenographic reports and memorial reconstructions.

\section{PiRACy BY STENOGRAPHY}

The clearest evidence of the pirating of plays by stenography comes from Thomas Heywood, who refers, in two separate passages, to the publication of mangled versions of his work. The first of these is less clear than the second. In the preface to The Rape of Lucrece (I608) he declares that "some of my plays have (unknown to me, and without any of my direction) accidentally come into the printer's hands, and, therefore, so corrupt and mangled (copied only by the ear) that I have been as unable to know them as ashamed to challenge them". The statement that these plays were "copied by the ear" does not necessarily imply that stenography was used, although it is reasonable to suppose that that is what Heywood meant. But in another well-known passage he is unequivocal.

In 1637 he published a collection of Pleasant Dialogues and Drammas, in which there was included a prologue to a "Play of Queene Elizabeth". I It is generally agreed that the play referred to is Heywood's If You Know Not $\mathrm{Me}$ You Know Nobody, or the Troubles of 2ueen Elizabeth, Part I, first published in 1605 by Nathaniel Butter. Of this play the author asserts in the prologue published in I6 37 that

some by Stenography drew

The plot: put it in print: (scarce one word trew)...

I See W. W. Greg, in The Library, 4th series, vol. xvIr (1936-7), p. 173 .

$\mathrm{D}$

of

th

ev

$\mathrm{kr}$

ha

w:

of

bu

th

$\mathrm{Si}$

in

an

ot

pe

pa

D

$\mathrm{ch}$

th

is

fir

er

ac

w

$\mathrm{m}$

ac

is

$\mathrm{O}$

as

$L i$

ibi 
Dr Greg fixes I6 62 as the probable date of the composition of this prologue. It was reprinted in the 1639 Quarto of the play.

At first sight it would seem that here we have the clearest evidence that the reporting of plays by stenography was a known practice in 1605 . ButSignor G. N. Giordano-Orsini has shown, to my mind quite conclusively, that Heywood was mistaken in his view of the nature of the transmission of this text. I It is undoubtedly "stolne and surreptitious"; but the theory of note-taking by a stenographer in the theatre fails to account for certain peculiarities which Signor Giordano-Orsini discusses-peculiarities which indicate quite another hypothesis.

He points to the inequality of the text. Often it is curt and abrupt, with numerous metrical deficiencies; on the other hand, at many points it is full and smooth, with perfect metrical structure. The cardinal point is that four parts are consistently good, those of Gage, King Philip, Dodds, and the Clown. Furthermore, when any of these characters are on the stage the quality of the speeches of the other characters is higher than when none of the four is present. Signor Giordano-Orsini suggests that the three first-named parts could be played by a single actor, and erects the hypothesis of memorial reconstruction by two actors. His conclusion is, then, that either Heywood was wrong or a stenographer's notes were supplemented by the memories, and perhaps the manuscript "parts", of the two actors. The theory of memorial reconstruction, however, is in itself adequate to explain the condition of the text.

Professor Pollard has pointed out ${ }^{2}$ that Signor GiordanoOrsini's discovery in no way invalidates Heywood's evidence as to the existence of the practice of pirating plays by

I See Times Literary Supplement, 1930, December 4; and The Library, 4 th series, vol. XIV (1933-4), pp. 31 3-38.

2 In The Library, 4th series, vol. XIV, p. 352. See also W. W. Greg, ibid. vol. XvIr, p. I74. 
stenographic reporting; rather the reverse. Heywood made his accusation about 1632 ; he knew that his play had been pirated in 1605 . If stenographers were known to go to theatres to take notes of plays for subsequent illegitimate publication, nothing would be more natural than for Heywood to jump to the conclusion that his play had been reported in this fashion. That he thought this is a fairly clear indication that the practice existed in the 1630 's, and probably a good deal earlier, since if it was in fact only a recent practice he would have been less likely to assume it for a play issued in 1605 .

It was largely upon Heywood's testimony that the view was formed that the spurious Shakespearian Quartos are stenographic piracies. It was for long the traditional hypothesis that Timothy Bright's system of Characterie, first published in I588, was employed. The study of this system of shorthand in connection with these texts was originally largely the work of German scholarship. ${ }^{\mathrm{I}}$

As far as the "bad" Quartos of Romeo and Fuliet, Henry $V$, The Merry Wives, and Hamlet are concerned, there are certain initial difficulties in the way of accepting the theory that stenographers, attending performances, were responsible for the copy for these editions. The first applies only to the last three texts, in which the parts of certain characters are consistently better reported than those of the others. This in itself might be explained on the

I Seè especially Curt Dewischeit, Shakespeare Fahrbuch, vol. xxxrv, 1898, pp. 170-220; P. Friedrich, Studien zur englischen Stenographie im Zeitalter Shakespeare (1914), and Archiv für Schriftkunde, 1915, pp. 88-140, 1916, pp. 147-88; A. Schottner, Archiv für Schriftkunde, I918, pp. 229-340; M. Förster, Shakespeare Fahrbuch, vol. LXvIII (1932), pp. 87-102. For discussions in English see Hereward T. Price, The Text of "Henry V" (1920), chapter III, pp. I I-19, and Essays in English and Comparative Literature (Michigan, 1933), pp. I62 ff.; G. B. Harrison, Bodley Head reprint of the first Quarto of Hamlet (1923), introduction, pp. xii-xix; Joseph Quincy Adams, Modern Philology, vol. xxxi (1933-4), pp. ${ }_{35} \mathrm{ff}$. 
stenographic theory by assuming that the enunciation of some actors was consistently slower and clearer than that of others. But there is more to be said: the comparative excellence of the reporting extends beyond the actual speeches of these characters, including also the speeches of other characters while these are on the stage. This is a distinct obstacle to the theory of stenographic reporting applied to these texts. Dr Price, for example, is forced to allow that in the case of the Quarto of Henry $V$ the activities of the stenographer were supplemented by reporting actors. ${ }^{\mathrm{I}}$

The second initial objection which I mentioned applies to all four of the texts named. They are full of transferences of words, phrases, and lines from one place to another, often at considerable intervals. The great frequency of these transferences is one of the most striking characteristics of these Quartos. One of the most recent critics to insist on the theory of stenographic reporting for the first Quarto of Hamlet is Dr B. A. P. Van Dam, ${ }^{2}$ who is forced to attribute all these transferences to the actors themselves; for a stenographer could hardly be expected to produce them. Thus Dr Van Dam has to assume an extraordinarily low standard of accuracy in the actors of Shakespeare's company-one of the principal London companies. Admittedly the Elizabethan companies were what we should call repertory companies, and a certain amount of inaccuracy was doubtless inevitable. But that in a leading company this should have been of the extent envisaged by Dr Van Dam is quite incredible. Both of these objections to the theory of stenographic piracy point directly to the hypothesis of imperfect memorial reconstruction by actors: for if one or two actors attempted to reconstruct a play, the standard of accuracy might well be low except at points where they were themselves involved.

I The Text of "Henry V", p. I 9.

"The Text of Shakespeare's "Hamlet" (1924), chapter I. 
Again, it is worthy of note that where errors occur in reported texts apparently through mishearing these are not necessarily to be taken as implying stenographic transmission. An actor may mishear a fellow-actor just as readily as a stenographer may. Furthermore, we cannot dismiss the distinct possibility that in a given case an actor, reporting a text from memory, may dictate to a scribe, who may at certain points mishear him. ${ }^{I}$

The theory of stenographic reporting by Bright's system in the case of the Shakespearian "bad" Quartos up to and including that of Hamlet has been demolished, in my view effectively, by $\mathrm{Mr}$ W. Matthews. ${ }^{2}$ I refer here to only one of the most important points he makes, claiming that these texts do not exhibit to any noticeable extent a type of error which would be most characteristic of this particular shorthand technique.

Dewischeit ${ }^{3}$ gives a full description of the system. Bright started with a straight vertical line, representing $a$. By adding different strokes, hooks, etc., to the top of this line he evolved seventeen other symbols. $K$ and $q$ were represented by $c$; $j$ and $y$ by $i$; $v$ and $w$ by $u ; x$ and $z$ were dropped out. Thus the twenty-four letters of the alphabet were represented by eighteen symbols. Furthermore, various distinguishing marks could be added to the foot of each of these symbols; altogether each could appear in twelve different forms. Now each sign could be written vertically, horizontally, slanted to the right, or slanted to the left. Thus the symbol for each letter could appear in forty-eight variant forms in all. Altogether the system made available 864 symbols. Now each of the forty-eight signs associated with one letter was taken to represent a word beginning with that letter; these words were called

I Cf. Greg, Two Elizabethan Stage Abridgements, p. 354 .

2 Modern Language Revierw, vol. xxvIr (1932), pp. 243 ff., and The Library, $4^{\text {th }}$ series, vol. Xv (1934-5), pp. $48 \mathrm{r} \mathrm{ff}$.

3 Op. cit. pp. $192 \mathrm{ff}$. 
"characterical words". Actually Bright did not use fortyeight characterical words beginning with each letter: under $a$ he gives only twenty-four, under $b$ forty, under $c$ all forty-eight (since $k$ and $q$ were also included), under $d$ thirty-two, under $e$ seventeen, and so on. The total number of characterical words is $55^{8}$.

A system of shorthand which could represent only $55^{8}$ words would, of course, be useless. So Bright evolved what he called "consenting method" and "dissenting method". By consenting method a synonym of a given characterical word was indicated by the symbol for that word, with the symbol for the initial letter of the synonym prefixed. By dissenting method an antonym of a given characterical word was indicated by the symbol for that word, with the symbol for the initial letter of the antonym suffixed. Bright gives a long list of words in alphabetical order, indicating in each case what characterical word was appropriate.

The symbol for a given characterical word could by consenting method indicate not only direct synonyms but also words clearly associated in some way with the characterical word: these were termed "appellative words". ${ }^{I}$ Thus, for example, the symbol for the characterical word "fruit" was used to denote different single fruits. Now in many cases there are several fruits the names of which begin with the same letter. If one wished to write the word "apple" by Bright's system one would write the symbol for the word "fruit" and, in front of it, the symbol for the letter $a$. But, when the shorthand was being transcribed, all that would be apparent would be that a fruit beginning with $a$ was intended. Reference to Bright's table of appellative words shows that among the fruits rendered by the characterical word "fruit" are apple, almond, acorn, and apricot. As far as the transcriber of the shorthand notes could know, any one of these might have been meant. The

${ }^{2}$ Bright also gives a table of appellative words. Groups of appellative words are placed under the appropriate characterical word.

D B $Q$ 
correct solution might be obvious from the context: or, if the stenographer and transcriber were the same person, memory might help. ${ }^{\mathrm{I}}$ But countless analogous cases could occur; and in the case of a stenographer reporting a play which he had attended on at most a few occasions memory could not be expected to come to the rescue very often.

It follows that if this system was used in the reporting of the Shakespearian "bad" Quartos up to 1603 , a not uncommon type of error in these Quartos would be the occurrence of a variant beginning with the same letter as the genuine reading. This type of error does occur. For example, in Henry $V$ Dr Price ${ }^{2}$ cites the following: iii I 55, $Q$ hurt, F harm'd; I ii 284, $Q$ wife, $F$ widows (both rendered by the characterical word "marry" with the sign for $w$ prefixed); i ii $308, Q$ check, $\mathrm{F}$ chide (both rendered by "rebuke" with ch prefixed); IV iii I 23, $Q$ nought, F none (both rendered by "some" with $n$ suffixed). But the number of such variants in the Shakespearian "bad" Quartos is utterly insignificant when compared with the tremendous number of variant readings, often synonymous with the genuine readings, which begin with a different letter. It seems quite clear that if Characterie was indeed employed the practitioners concerned did not understand consenting method. For we could only assume that in the vast majority of cases where it was necessary to indicate synonyms of characterical words they omitted to insert in front of the symbols for these the signs which would convey the initial letters of the synonyms. But it is much more reasonable to suppose that the system was not used when we find that the characteristic error which it would encourage is not exemplified to any great extent in these Quartos.

I In Modern Philology, vol. xxxIII (1935-6), p. 155, Miss Doran suggests (with acknowledgement to Dr Greg) that Bright's system, "being based primarily on sense and not on sound,.. is intended as an aid to memory".

${ }^{2}$ Op. cit. p. ${ }^{4}$. 
Apart from this altogether, there is, as I have said, internal evidence in the "bad" texts of Henry $V$, The Merry Wives of Windsor and Hamlet that the method of transmission in these cases was memorial reconstruction effected by the actors who took certain parts. These parts are consistently better reported than the others. And the quality of the reporting of the other characters is higher when these actors are on the stage. In the first Quarto of Romeo and Fuliet there is no part consistently better reported than the others. But here if anywhere we can say confidently that Bright's Characterie will not account for the transmission of the text. In addition to the argument already adduced, we find that this is in many ways the best reported of the Shakespearian "bad" texts. There is very little mislineation - one of the faults we should most expect in a shorthand report: and there is comparatively little metrical deficiency. Bright's system was exceedingly cumbersome, and could hardly have given such good results as we have here. As $\mathrm{Mr}$ Matthews points out, there is a very large number of words in the "bad" Quartos not assigned by Bright to any characterical word. Shakespeare's vocabulary is extraordinarily rich. If Characterie were used in reporting him, the stenographer would find that on countless occasions he would have to pause and think what characterical word he could use. This would result in his being unable to note down what was said immediately after the word over which he paused. But the standard of the reporting of at least great parts of QI Romeo and Fuliet is far too high to make it possible to suppose that this clumsy system was employed in its transmission.

It has been claimed that the system was an efficient one, but examination of the evidence reveals it as by no means good. Characterie appears to have been used in reporting sermons. Dr Price has made a close comparison of the two extant versions of Henry Smith's sermon entitled "A Fruitefull Sermon Vpon part of the 5. Chapter of the first 
Epistle of Saint Paul to the Thessalonians". The first edition (I 59I) contains a text which is stated on the titlepage to have been "taken by Characterie". In the following year an authorized edition was published. ${ }^{\mathrm{I}}$

In his Text of "Henry $V$ " (p. I 2) Dr Price sets out a passage of this sermon as it appears in the reported and in the authentic versions. Certainly the former is very close to the latter; and from this Dr Price argues for the efficiency of Characterie as a shorthand method. But again $\mathrm{Mr}$ Matthews has a cogent counter-argument. ${ }^{2}$ He suggests that this may be an analogous case to that of another sermon of Smith's entitled "A Sermon of the Benefite of Contentation". The text of the first edition (also I 59I) is stated on the title-page to have been "taken by characterie". In the same year an amended reprint was issued; on the title-page of this we are told that the sermon was "taken by characterie, and examined after". Almost immediately Smith brought out an authorized edition; on the title-page the text is said to be "newly examined, and corrected by the author". Of this authorized edition Mr Matthews writes as follows: 3 "In the preface... Smith said that he had taken pains to 'perfit the matter and to correct the print'. This apparently means that he adopted the text of the pirated copy and merely corrected it, and this may well have been his method for A Fruitfull Sermon." We cannot be sure that in comparing the pirated text of the latter with the authorized one we are comparing the report with the original sermon which the stenographer heard. Consequently all deductions made from such a comparison relative to the efficacy of Characterie are at least suspect.

$-\mathrm{Mr}$ David Salmon 4 reminds us that Bright himself

I Price has published a reprint of both versions, with an introduction -A Fruitful Sermon, 1922.

${ }^{2}$ Modern Language Revierw, vol. xxvII (1932), pp. 248-9, 255-9.

3 Ibid. p. 257.

4 Times Literary Supplement, 1919, pp. 69-70. 
admitted that a discourse could not be taken down by his system unless "uttered as becommeth the grauitie of such actions". And Mr Matthews ${ }^{\mathrm{I}}$ shows that in a version of one of Egerton's sermons, produced in I 589 by one A.S., "taken as it was uttered by Characterie", the reporter claims for his reproduction not phraseological accuracy but the fact that he has "not missed one word whereby either the truth of doctrine might be peruerted or the meaning of the preacher altered". In other words he claims to reproduce the content correctly, but he does not claim to do so in the same words as the preacher used.

A Shakespeare play was certainly not delivered on the stage with the "grauitie" that "becommeth" a sermon. It seems to me utterly inconceivable that Bright's Characterie could yield results so good as even the poorest Shakespearian pirated texts give. The difficulties presented by the method (both generally and with regard to Shakespeare plays) are admirably epitomized by Mr Matthews: ${ }^{2}$

... In computing the utility of Bright's system we must consider: (I) the tremendous grasp of English vocabulary required by the stenographer; (2) the degree of mental alertness necessary to assign words to their true Charactericall words; (3) the difficulty of learning and of distinguishing between over $55^{\circ}$ words (if particles are included) which have very similar signs; (4) the slowness of the system caused by the method of writing in columns and the necessity of moving the hand backwards to write the initial letters.

The system was doubtless efficacious under some circumstances-when, for example, the spoken matter to be reported was not lengthy and when it was desired to note down only the gist of the contents and not to give a verbatim reproduction. But that it could furnish reports of Shake-

I The Library, 4th series, vol. xv (1934-5), p. 496.

2 Modern Language Revierw, vol. XxvII (1932), p. 254. 
speare plays, reports of the standard of those with which we have to deal, is unthinkable. ${ }^{\mathrm{I}}$

We have already seen that the fact that Heywood was wrong in declaring that If $Y$ ou Know Not Me, Part I was pirated by stenography in no way invalidates his testimony of the existence of the practice of reporting plays in this manner. Heywood's accusation was made in the I630's, and Bright's system was not the only one which might have been used even in 1605 . In 1602 John Willis published a much more efficient system, using a different principle. Now I have said that the "bad" Quartos of Henry $V$, The Merry $W$ ives of $W$ indsor and Hamlet give evidence, by the inequality of the reporting of different parts, of being memorial reconstructions. There is no such inequality in that of Romeo and Fuliet, but the standard is so high that Bright's system is out of the question and it is too early for that of Willis. If the Shakespearian "bad" Quartos up to I603 are not stenographic piracies, are there any which are?

The question of the nature of the transmission of the Q I text of King Lear (1608) is one which has recently occupied a good deal of critical attention. Sir Edmund Chambers regards it as a piracy, and suggests that "possibly it was produced by shorthand and not memorization". ${ }^{2}$ Dr W. W. Greg also regards it as a stenographic report; he stresses the frequency of mislineation in the text. 3 Professor Quincy Adams believes that Bright's Characterie was employed. 4 The other side in the controversy is represented by $\mathrm{Mr}$ Edward Hubler 5 and Miss Madeleine

I The same is true of Peter Bales's Brachygraphy, published in I 590 , which was the same as Bright's system in principle, being indeed largely plagiarized from him. See Matthews, Modern Language Review, vol. XxvIrI (1933), pp. 8 r -3 .

2 William Shakespeare (1930), vol. I, p. 465.

3 Neophilologus, vol. xvirI (1933), pp. 241-62: The Library, 4th series, vol. XVII (1936-7), pp. 172-83.

4 Modern Philology, vol. xxxi (1933-4), pp. I35ff.

5 Essays in Dramatic Literature. The Parrott Presentation Volume. Ed. Hardin Craig (1935). Princeton. 
Doran, ${ }^{\mathrm{I}}$ neither of whom regard Q I Lear as a reported text. $\mathrm{Mr}$ Hubler attributes the mislineation to the compositor's efforts to save space. But Dr Greg has pertinent arguments against this position. ${ }^{2}$ Hubler states that approximately 500 verse-lines are set up as prose, and that this saves much space. But Greg asks why, if the compositor desired economy in this respect, he did not set up all the verse as prose, a procedure adopted in the 1678 Quarto of The Elder Brother, a verse play. He points out that approximately two-thirds of the verse in Q I Lear is correctly divided, with no effort at compression, and further, that some sixty lines of prose are set up as verse, which actually results in waste of space. The $\mathrm{Q}$ I punctuation is defective; this, with the mislineation, seems to Dr Greg to point to the hypothesis of stenographic reporting. "A stenographer does not produce mislining directly", he writes. "His shorthand report will contain no indication of line division at all. And it was a longhand transcription of such a report, undivided metrically and practically unpointed, that I postulated as copy. The actual misdivision would, of course, be the work of the compositor, as $\mathrm{Mr}$ Hubler contends." 3 Considering the fact that much of the text is correctly divided, Dr Greg suggests that this "is just what we should expect of two or more compositors of different ability making what they could of copy that presented no metrical division at all".4 Miss Doran's view is, on the contrary, that "the first quarto was set up from a manuscript containing the first draft of the play much revised, and that the folio was set up from a shortened transcript of this revised manuscript". 5

It is not my purpose to discuss the respective merits of the two hypotheses. What concerns us here is the conclusion

The Text of "King Lear", Stanford University Publications, Language and Literature, vol. IV, no. 2, r93 r.

2 See The Library, vol. xvII, p. 176.

3 Ibid. p. 175 .

4 Ibid. p. 176.

5 Op. cit. p. 100. 
that if QI Lear is a reported text, it is not a memorial reconstruction but a stenographic report. The text is in very much better condition than the first Quartos of Henry $V$, The Merry $W$ ives, and Hamlet. It contains none of the marks of memorial reconstruction found in these texts in plenty. But if Q I Lear is a stenographic piracy, I cannot see that it can have been transmitted through the shorthand system of Bright, or through that of Bales, plagiarized from Bright. Neither of these could have yielded results so good. ${ }^{\mathrm{I}}$

Professor Quincy Adams finds in Q I variations from the corresponding Folio readings which suggest Characterie. For example, he cites instances of the substitution in Q I of synonyms beginning with the same letter as the corresponding genuine readings of the Folio. ${ }^{2}$ But in a refutation of his hypothesis Miss Doran deals effectively with this. ${ }^{3}$ She has herself found about a hundred and thirty of these synonymous or nearly synonymous variations between Q I and F. "Of these", she says, "only fourteen are related to a common word in Bright or have the reading in $\mathrm{Q}$ which would best represent, in Charactery, the Folio reading." 4 Apparently, then, if the Q I text was taken down by a practitioner of Characterie, he did not know Bright's tables of equivalents. Miss Doran admits that a stenographer "would not necessarily in all cases conform to Bright's lists"; 5 but she points out that we must test the hypothesis of Characterie by its own rules, since these variations may have arisen at some other stage in the transmission of the $\mathrm{Q}$ I text (regarded as pirated) - for example, in the actors' mouths. And here we come to a most important point. Of the numberless differences between Q I and F only some point to Characterie: others

I See Greg, Neophilologus, vol. xvirr (1933), p. 256.

2 Op. cit. pp. 146-8.

3 Modern Philology, vol. xxxirr (1935-6), pp. I 39 ff.

4 Ibid. p. 146.55 Ibid. p. 145.

are

Mis

as $\mathrm{t}$

sync

$\mathrm{OCCl}$

is $n$,

set ,

Ans

cert

of ,

mnt

thes

prol

a re

pira

Bris

graf

hav

"W

dep

this

$\mathrm{Neq}$

exp

cert

addi

fron

$\mathrm{P}$
desc

is $t$

legi

all

cont 
are attributed by Professor Adams to the actors. On this Miss Doran says: "From the point of view of Charactery as the agency of production it is possible to exclude certain synonymous or quasi-synonymous variants as unlikely to occur because Bright does not associate them together. It is not equally possible to exclude from the actor's range the set of variants that may be assigned to the stenographer."I And again: "...the conclusion that Charactery has certainly given rise to a selected number out of the total class of variants which might have come about through any mnemonic agency is clearly inadmissible."2

The problem of the first Quarto of King Lear remains, then; and all that we need say in this general survey of problems connected with "bad" Quartos is that it may be a reported text, in which case it is probably a stenographic piracy and the product of a system other than that of Bright.

Another fragment of text has been claimed as a stenographic report. Copies of Richard II published in 1608 have two different title-pages. The later contains the words "With new additions of the Parliament Sceane, and the deposing of King Richard". Professor Pollard deals with this passage (IV i I 54-3I8) in his King Richard II: $A$ New 2uarto (pp. 62-3). He concurs with the opinion expressed by W. A. Harrison, 3 who states that "it seems certain from the context that this passage... was not an addition to the play; but for some reason had been omitted" from the earlier text.

Professor Pollard considers that the text of the passage described by the publisher, Matthew Law, as an addition is too corrupt for us to be able to suppose that it was legitimately obtained from the King's Men. It was in all probability illegally procured "by suborning someone

I Op. cit. p. r4o.

${ }^{2}$ Ibid. p. 148.

3 In the introduction to the Griggs facsimile of the 1608 Quarto containing the passage in question. 
employed in the theatre to make a surreptitious copy, or by persuading someone employed in the theatre, or sent to it for the purpose, to take down the lines in shorthand, or to learn them by heart and dictate them to the printers". I But Pollard doubts whether even a surreptitious transcript could result in so corrupt a text, and considers it most probable that the copy was "procured by means of shorthand writers specially sent... for the purpose". It is interesting to notice that both the first Quarto of King Lear and the deposition scene in Richard II appeared after the publication of John Willis's system of shorthand in I602. So stenography remains a factor to be reckoned with in the general study of "bad" Quartos.

\section{Memorial Reconstruction}

In 1857 Tycho Mommsen wrote of the first Quarto of Hamlet: "I apprehend that I discern two hands employed, one after the other, upon this Hamlet, the one being probably that of an actor, who put down, from memory, a sketch of the original play, as it was acted, and who wrote very illegibly; the other that of a bad poet, most probably 'a bookseller's hack', who, without any personal intercourse with the writer of the notes, availed himself of them to make up this early copy of Hamlet." 2 Thus Mommsen regarded this spurious text as basically an actor's memorial reconstruction, though he made no suggestion as to the part or parts which the actor concerned had played. To the best of my knowledge, Mommsen was the first critic to advance the theory of memorial reconstruction to explain an illegitimately published Shakespearian text.

In his Harness Prize Essay on the first Quarto of Hamlet (1880), W. H. Widgery compared the part of Voltemar in that text with the versions of the later editions,

I Op. cit. p. 64 .

The Athenaeum, vol. xxrx, p. I82. 
and noticed that in the first Quarto it is reproduced with a fidelity conspicuously above the average. Taking this into account, he suggested that the first Quarto represents a version of an early Shakespearian Hamlet (written between I 596 and I 598), stolen by an actor who had played the part of Voltemar. He further suggested that the condition of the first Quarto text of the Player-Duke's speeches warranted the additional supposition that the pirate-actor also took this part. Now whereas the text of Voltemar's long speech (corresponding to II ii 60-80 of the received text) and of the single line he speaks along with his fellowambassador (corresponding to $\mathrm{r}$ ii 40 ) is obviously an extraordinarily faithful reproduction of these passages as found in the authentic editions, the first Quarto version of the Player-Duke's initial speech is entirely different from that in the second Quarto and the Folio. ${ }^{I}$ Widgery's theory implies, therefore, that, revising the hypothetical play of I 596-8, Shakespeare left Voltemar's part as it was, but substantially altered that of the Player-Duke (Player-King in the later texts).

In I9I0 Dr W. W. Greg published an edition of the Quarto of The Merry Wives of Windsor. ${ }^{2}$ This contains an important introduction, in the course of which the author expresses the opinion that "the supposition of neither shorthand nor longhand notes is necessary to account for the text as we have it. The very best passages of the Quarto are easily within the reach of an even inexpert pirate relying on memory alone" ${ }^{3}$ H. C. Hart had pointed out that the part of the Host of the Garter Inn is reproduced remarkably fully in the Quarto. ${ }^{4}$ Dr Greg notes, in addition to this, "the comparative excellence of

${ }^{1}$ Compare QI scene ix lines roo-7 with III ii ${ }_{153}-8$ in the received text.

2 Oxford: Tudor and Stuart Library.

3 Op. cit. pp. xxxvi-xxxvii.

4 The Merry Wives of Windsor, Arden edition (1904), p. xx. 
the reporting of those scenes in which the host is on the stage even where he takes no prominent part in the conversation".' This, along with the fact that in the Host's speeches there are numerous small divagations from the Folio text too trifling to be attributed to revision, effectively puts out of court any suggestion that the Host's manuscript "part" was available to the compiler of the Quarto version. Dr Greg advanced the hypothesis, now widely accepted, that an actor who had taken this part wrote down the entire Quarto text from memory. There is no reason to suppose that he merely assisted a shorthand reporter, since, as Dr Greg points out, there is "no justification for conjecturing two agents where one will suffice". ${ }^{2}$ His proof that the text of this Quarto is a memorial reconstruction made by Mine Host of the Garter is one of the two main foundation-stones of the present-day study of "bad" Quartos which have been securely laid by Dr Greg.

In an article published in $1915^{3}$ Professor H. D. Gray reverted to Mommsen's suggestion that a hack-poet assisted in the preparation of the text of the first Quarto of Hamlet. This hack-poet supplemented an imperfect memorial reconstruction of the Shakespearian play as it stood in I600-I; and the memorial reconstruction was the work of an actor who had played the part of Marcellus in that play. Professor Gray observes that the scenes in which Marcellus appears are conspicuously well reported; but he lists numerous small errors in Marcellus's own speeches. The existence of these, and the fact that in the scenes in which Marcellus appears the high standard of the reporting also involves speeches by other characters, militates against the supposition that Marcellus's manuscript "part" was used in the preparation of the illegitimate text. These conditions indicate the hypothesis of memorial reconstruc-

I Op. cit. p. xxxviii. $\quad 2$ Ibid. p. xli.

3 Modern Language Revierw, vol. x, pp. 17 I-8o. 
tion by the actor concerned. Professor Gray also notes the excellent quality of the first Quarto version of the playwithin-the-play, and suggests that that version is a very good report of material which underwent some revision before the second Quarto appeared. Thus "Marcellus" may also have taken the part of one of the Players. In a later article $(1927)^{\mathrm{I}}$ Professor Gray suggests that the part he took here was that of Lucianus. The speech in the first Quarto which corresponds to IIr ii 255-60 in the received text is most noticeably accurate.

Here then we have hypotheses postulating memorial reconstruction of texts by one actor. The evidence is inequality of the standard of reporting, the speeches of certain characters being consistently on a higher level than those of the others, and the general level of the text being higher where these characters are present on the stage.

As we have already seen in the case of If You Know Not $M e$, Part I (1605), more than one actor may be involved in a memorial reconstruction. Consider the spurious text of Henry $V$ (I600). Dr H. T. Price argues that the text it gives is in the main a stenographic piracy, but that this method of transmission was supplemented by other means. ${ }^{2}$ He points out that the parts of Gower and the Governor of Harfleur are reported with great accuracy, and suggests that the speeches of these characters in the Quarto were taken from the manuscript "parts" of the actor or actors who played the two rôles. $\mathrm{He}$ also finds the Quarto version of Exeter's part distinctly above the average. "On the whole", he says, "I am inclined to believe that Exeter's speeches were supplied by an actor, though they are marred by many faults. Exeter is not nearly so well reported as Gower." 3 Presumably, therefore, Dr Price considers that

${ }^{1}$ Publications of the Modern Language Association of America, vol. XLII, pp. $72 \mathrm{I}-35$.

2 See p. I 5 supra.

3 The Text of "Henry $V$ ", p. I9. 
an actor who had taken the part of Exeter reconstructed his speeches from memory. ${ }^{\mathrm{x}}$

I am convinced that memorial reconstruction played a much larger part than Dr Price admits in the transmission of this "bad" text. The superlative quality of the reporting of Gower's speeches is a most striking fact. But, in suggesting that this is due to the compilers of the Quarto text having had access to the manuscript "part" of the actor concerned, Dr Price leaves out of account two very important points. First, the excellence of the reporting is not confined to Gower's own speeches, but extends also to the speeches of the other characters present while he is on the stage: this is very noticeable, for example, in the Quarto version of Act III, scene vi, a long and difficult scene. Secondly, as Dr Price himself points out, "Gower is the best reported character in the Quarto, yet even his speeches are not linked bibliographically with the Folio".2 Now the Governor's single speech (III iii I 2-I 8 in the Quarto) is linked bibliographically with the Folio (III iii 44-50). 3 The two texts of the speech must depend

I Price notes the excellence in the Quarto of "the difficult piece of Latin and French at the end of v ii", and suggests that at this point alone in Exeter's part "there must have been some good manuscript before the compositor" (op. cit. p. I9).

${ }^{2}$ Op. cit. p. 11 .

3 The bibliographical link is the punctuation. The Folio version of the speech contains three colons-after "end" (line 44), after "Siege" (line 47), and after "Mercy" (line 48). All three colons appear in exactly the same positions in the Quarto, which introduces no others. Of the seven commas in the Folio, five are reproduced at the same points in the Quarto-F line $45 \mathrm{Q}$ line 13 "entreated,": F line $46 \mathrm{Q}$ line 14 "ready," : F line $47 \mathrm{Q}$ line 15 " "King,": $F$ line 49 " Gates," $Q$ line 17 " "gates,": F line $49 Q$ line 17 "ours,". One other is reproduced at the corresponding point though the text varies-F line 46 " Returnes vs, that his" $Q$ line 14 "Returnes vs word, his". The only difference in punctuation between the two texts is the Quarto's omission of the comma after "Dolphin" (F line 45, cf. Q line $\mathrm{r}_{3}$ ), which is quite insignificant. This virtually complete agreement in punctuation cannot be coincidence; both versions must be derived ultimately from

the

bel

the 
ultimately upon the same manuscript. The actors' "parts" were presumably transcribed from the prompt-book; and we may safely assume that the prompt-book, or a transcript of it, or the author's manuscript from which it was copied with or without adaptation, underlies the authentic (Folio) text of Henry $V$. Unless we suppose that when he came to this speech the Folio compositor suddenly felt constrained to consult the Quarto and reproduce its punctuation (which seems extremely unlikely) we must suppose that a transcript of the Governor's "part" underlies the Quarto. If Gower's "part", or a transcript of it, underlay this text, we should expect in his speeches similar bibliographical links with the Folio, and these, on Dr Price's admission, we do not find. The only possible hypothesis is that an actor who had played Gower assisted in the

the same manuscript. Admittedly there are textual variations; and I believe that what underlies the Quarto immediately is a transcript of the Governor's "part". The variations are as follows: F line 45 "Succours" $Q$ line ${ }_{13}$ "succour": $F$ line 46 " Returnes vs, that his" $Q$ line I4 "Returnes vs word, his": F line 46 "yet not" $Q$ line $\mathrm{I}_{4}$ "not yet": F line 47 "great" $Q$ line 15 "dread": $F$ line 50 "defensible" $Q$ line 18 "defensiue now". Of these the first and third are insignificant; behind either text may lie simple errors of transcription or type-setting. As for the variant "defensible/defensiue now" it seems likely that either the person who made the illegitimate transcript of the "part" for the Quarto, or the compositor, looked carefully only at the beginning of the word, jumped to a wrong conclusion, and wrote (or set up) "defensiue"; then he, or some "editor", seeing the resultant metrical deficiency, made this good by inserting "now". There remain two serious variations; and we may suppose that the person who transcribed the "part" for the Quarto was someone who knew the play well, who was consequently a little careless in the reading of his copy, and who was influenced at these two points by reminiscences of other passages. Thus he may have written "Returnes vs word, his powers are not yet ready" through anticipation of III v 69 (F) where the French King says "quickly bring us word of England's fall"; and very possibly he substituted "dread King" for "great King" as the result of a recollection of I ii 99 (F) where we have "dread Soueraigne" and, six lines further on, "my dread Lord". At any rate, the evidence of the punctuation is quite conclusive. 
compilation of the Quarto text by memorial reconstruction. So also in all probability did an actor who had played Exeter. These two parts can hardly have been doubled, ${ }^{\mathrm{I}}$ so we may regard the "bad" text of Henry $V$ as basically a memorial reconstruction made by two actors, who happened to have access to two paltry scraps of manuscript. ${ }^{2}$

Hitherto we have been discussing memorial reconstruction by one or two actors. We must now consider the second of the critical foundation-stones laid by Dr Greg. In 1922 the Malone Society issued, as an extra volume, his Two Elizabethan Stage Abridgements: "The Battle of Alcazar" and "Orlando Furioso". In the second part of this work the author makes a meticulously detailed analysis of the Quarto text of Greene's Orlando Furioso (published in I594), along with the extant manuscript "part" of Orlando. He finds that the Quarto reproduces a text "severely abridged by the excision of scenes, speeches and passages of dialogue, as well as by compression and the omission of characters, for performance by a reduced cast in a strictly limited time". 3 He shows that the text "has been adapted, by the insertion of episodes of rough clownage and horseplay, to the tastes of a lower class of audience", 4 and suggests that the bulk of the alterations "represent a

I In Q Exeter and Gower appear together in IV viii. Exeter appears in IV vi: after his last speech there are only five lines, two of which are a direct reply to him: but Gower comes on at the beginning of the next scene and speaks at the fourth line. A similar obstacle stands in the way of Giordano-Orsini's suggestion that the parts of Gage and Philip in If You Know Not Me, Part I were played by the same actor; Philip speaks the last line of scene xiii, and Gage enters at the beginning of scene xiv and speaks the fifth line. There is obviously no time for a change of costume, without which, however, audiences would have difficulty in distinguishing between the different characters played by the same actor. It seems likely, then, that more than two actors were involved in the memorial reconstruction of the Heywood play.

2 The second being the piece of Latin and French at the end of $\mathrm{v}$ ii.

3 Op. cit. pp. $133-4$.

4 Ibid. p. I 34 . 
gradual adaptation of the play to altered circumstances in the course of repeated acting. Thus the Quarto contains what would appear to be essentially a stage version: the text is dependent on, not antecedent to, actual performance. Moreover, the text is not even the result of bringing the original playhouse copy into accordance with the current stage version, but is based almost throughout on reconstruction from memory, while there seems likewise to be an oral link in the transmission". I Dr Greg also finds that "the copy used for the printed Quarto was in the first instance prepared for playhouse use". 2

Dr Greg reconstructs the text-history of the play as follows. ${ }^{3}$ The Queen's Men seem to have acquired it in I 591. About the end of I 592 or the earlier part of I 593, being in a precarious financial condition, they appear to have sold several of their plays. Orlando was acquired from them by Edward Alleyn, who was at that time acting with Lord Strange's Men. The Queen's Men, however, continued to perform the play in the provinces, although they no longer possessed the manuscript. Their fortunes continued to deteriorate, and they seem to have been forced gradually to get rid of their hirelings. Thus constant readjustment was necessary in the text, for performance by a diminished cast. Further alteration was made necessary by the greater popularity of comic material and the unpopularity of heroics. Thus the comic portions of the play were developed, and the more serious parts cut down. Constant acting led to corruption which could not be regulated, inasmuch as the company had no prompt-book. And owing to "the frequent rearrangement of parts to the capacities of a diminishing company" many of the actors were "forced to learn their speeches by ear in the course of rehearsal". 4 Finally, the company realized the advisability of furnishing itself somehow with a prompt-book. "All the members who

I Op. cit. p. I34.

3 Ibid. pp. $35^{2-7}$.
2 Ibid.

4 Ibid. p. 354 . 
had a working knowledge of the play met together and, having secured the services of a ready writer, proceeded in turn to dictate their parts as well as their memories would allow." Here, then, we have a memorial reconstruction made by an impoverished company of players working in the provinces without acting copy.

While Dr Greg was working towards this conclusion in the case of Orlando Furioso, Mr R. Crompton Rhodes was independently working towards a similar explanation of the "bad" Quartos of Romeo and Fuliet, Henry V, The Merry $W$ ives of Windsor, and Hamlet. In his Shakespeare's First Folio (1923) he advances the theory that "certain Players turned strollers, profiting by the accidental retention of their parts, and constructing the rest from memory, made prompt-books for the companies they joined". He accounts for the manuscripts which formed the copy for the four Quartos by the following hypothesis:

(i) each was a prompt-book used by the strolling players, (ii) each was prepared by some actor who had played a part in Shakespeare's play in the Lord Chamberlain's Company in London, (iii) the basis of each version was this accurate part, the rest being constructed from memory, most fully in scenes where he had played, (iv) the traces of shorthand in certain plays are due to the pirate's dictation to a confederate, (v) the abridgement was less deliberate than determined by his failure of memory, (vi) the versions (except possibly The Merry Wives) were subsequent to the Folio version, (vii) the stationers were not at all concerned in the piracy, but only in the printing. ${ }^{2}$

One may disagree with certain details here, apart from the question of whether there are any traces of stenography. It is incredible that the first Quarto text of Romeo and Fuliet was constructed by a single actor. No part is consistently good, none consistently bad, and none consistently better than any other. What accurate part formed the 
basis of this reconstruction? Again, there are in the Quarto of Henry $V$ definite traces of deliberate abridgement. But these are details, and taken generally the hypothesis commands serious attention.

$\mathrm{Mr}$ Crompton Rhodes had been led in the direction of this hypothesis by his researches on Sheridan, in the course of which he discovered evidence of memorial reconstruction for provincial performance at that later time. ${ }^{\mathrm{I}}$ Of particular interest are two cases of piracy of Sheridan plays where the pirates themselves have left on record accounts of their methods of reconstruction. Both reconstructions were made for unauthorized performances in the provinces.

In his $W$ andering Patentee (I 795), Tate Wilkinson, manager of the Theatre Royal, York, tells how, having tried in vain to acquire a copy of $T$ he Duenna from Harris, the patentee, of Covent Garden Theatre, he constructed a version of his own, which was first produced on Easter Monday, I 776. This pirated version subsequently received many performances. $\mathrm{Mr}$ Crompton Rhodes quotes Wilkinson's own account of the procedure he adopted. ${ }^{2}$

The fashion of not publishing is quite modern, and the favourite pieces not being printed, but kept under lock and key, is of infinite prejudice to us poor devils in the country theatres, as we really cannot afford to pay for the purchase of MSS. The only time I ever exercised my pen on such an occasion was on a trial of necessity. Mr Harris bought that excellent comic opera of The Duenna from Mr Sheridan. I saw it several times, and finding it impossible to move Mr Harris's tenderness, I locked myself up in a room, set down first the jokes I remembered, then I laid a book of the songs before me, and with magazines kept the regulation of the scenes, and by the help of a numerous collection of obsolete Spanish plays I produced an excellent opera; I may say excellent -and an unprecedented compliment; for whenever Mr Younger,

I See Times Literary Supplement, 1925,.pp. 599 and 617; Rhodes' edition of Sheridan's plays and poems (r928), vol. I, pp. 255-68 and vol. II, pp. I62-4; and The Library, 4th series, vol. IX (1928-9), pp. $233 \mathrm{ff}$.

2 The Library, 4 th series, vol. Ix, pp. 240-1. 
or any other country manager wanted a copy of The Duenna, $\mathrm{Mr}$ Harris told them they might play Mr Wilkinson's: hundreds have seen it in every town in Great Britain and Ireland.

Secondly, Mr Crompton Rhodes quotes the account given by an actor, John Bernard, of his method of reconstructing The School for Scandal for an unauthorized performance at Exeter in I 779. ${ }^{\mathrm{I}}$ The account appears in Bernard's Retrospections of the Stage (1832). Bernard tells how Hughes, the manager of the theatre at Exeter,

wanted a powerful novelty, and proposed The $S$ chool for $S$ candal, then new and greatly discussed. Its success at Bath had dispersed its fame about the West of England, and it was highly probable that, if the play were produced at Exeter, it would run a number of nights to full houses. But the Comedy was not yet published and the managers who had copies of it, had obtained them on condition that they did not permit the same to become the parents of others.....Under these circumstances I offered to attempt a compilation of the comedy, if $\mathrm{Mr}$ Hughes would give me his word that the manuscript should be destroyed at the end of the season. This was agreed to, and I set about my task in the following manner. I had played Sir Benjamin at Bath and Charles at Richmond, and went on for Sir Peter one or two evenings when Edwin was indisposed; thus I had three parts in my possession. Dimond and Blissit (Joseph and Sir Oliver) transmitted theirs by post, on conveying the assurance to them which $\mathrm{Mr}$ Hughes had to me. Old Rowley was in the company, and my wife had played both Lady Teazle and Mrs Candour. With these materials for a groundwork, my general knowledge of the play collected in rehearsing and performing in it above forty times, enabled me in a week to construct a comedy in five acts, called, in imitation of the original, The School for Scandal.

Result, the public not being let into the secret the play drew crowded houses twice a week to the end of the season.

We find, then, that just as Shakespeare's company withheld their plays from publication as long as possible

${ }^{1}$ Times Literary Supplement, 1925, p. 617. 
in their own interests, so also some of Sheridan's plays were kept unpublished. In both cases piratical attacks were successfully carried out despite the precaution. And the methods employed by Wilkinson and Bernard are similar to those which we can assume in memorial reconstructions of the Elizabethan period.

On the twin foundations of Dr Greg's investigation of Orlando Furioso and Mr Crompton Rhodes's work on Sheridan rests Professor Peter Alexander's important contribution to the study of "bad" Quartos. In I 594 and I595 respectively there were published two Quartos entitled The First Part of the Contention betwixt the two famous Houses of Yorke and Lancaster and The True Tragedie of Richard Duke of Yorke, and the death of good King Henrie the Sixt. Professor Alexander shows quite conclusively that the texts given in these Quartos represent, not 2 and 3 Henry $V I$ at a stage in their development anterior to that of the Folio texts, but memorial reconstructions of these texts themselves, or of texts extremely close to them. ${ }^{\mathrm{I}}$ The demonstration of this hypothesis had been begun by the late Dr John Semple Smart, ${ }^{2}$ whose work Professor Alexander has continued and developed. The "bad Quarto theory" is not itself new; but what is of prime significance is Professor Alexander's claim that the two Contention plays are members of the same class of text as the Quarto of Orlando Furioso, vamped up by a remnant of an acting company, deprived of promptcopy and anxious to continue performing in the provinces.

In his Dissertation on the Three Parts of King Henry VI Malone wrote as follows:

It has long been a received opinion that the two quarto plays... were spurious and imperfect copies of Shakespeare's Second and Third Part of King Henry VI.; and many passages have been

I See Shakespeare's "Henry VI" and "Richard III" (1929).

2 See Shakespeare, Truth and Tradition (1928), pp. 19r ff. 
quoted in the notes to the late editions of Shakespeare as containing merely the various readings of the quartos and the folio: the passages have been supposed to be in substance the same, only variously exhibited in different copies. The variations have been accounted for, by supposing that the imperfect and surreptitious copies (as they were called) were taken down either by an unskilful short-hand writer, or by some auditor, who picked up "during the representation what the time would permit, then filled up some of his omissions at a second or third hearing, and when he had by this method formed something like a play, sent it to the printer". To this opinion, I with others for a long time subscribed. ${ }^{I}$

But Malone finally dismissed this hypothesis, and formed the opinion that the Quartos represent "not spurious and imperfect copies of Shakespeare's pieces, but elder dramas on which he formed his Second and Third Part of King Henry VI". 2 These "elder dramas" he regarded as nonShakespearian.

The grounds upon which Malone founded this theory scarcely stand examination. He points out, for example, that

in some places a speech in one of these quartos consists of ten or twelve lines. In Shakespeare's folio the same speech consists of perhaps only half the number. A copyist by the ear, or an unskilful short-hand writer, might mutilate and exhibit a poet's thoughts or expressions imperfectly; but would he dilate and amplify them or introduce totally new matter? Assuredly he would not. ${ }^{3}$

But Mommsen ${ }^{4}$ and Creizenach 5 would have had an answer to this; in the case of the first Quartos of Romeo and Fuliet and Hamlet, Mommsen suggested that an inferior

I Boswell's ed. of Malone's Shakespeare, I82 I, vol. xvIII, pp. 577-8.

${ }^{2}$ Ibid. p. 578.

3 Ibid.

4 The Athenaeum, vol. $\mathrm{xxrx}, \mathrm{I} 857$, p. 182 .

5 Shakespeare Fahrbuch, vol. xLII, 1906, pp. $76 \mathrm{ff}$. 
poet supplemented, largely by his own invention, imperfect reports of the Shakespearian versions. Creizenach advanced the same view of the first Quarto of Hamlet.

What Malone regarded as "the chief hinge" of his argument was a certain interpretation of a passage in Greene which Dr Smart and Professor Alexander have shown to be a mistaken one. In his Groatsworth of Wit (1592) Greene includes an epistle entitled "To those Gentlemen his Quondam acquaintance, that spend their wits in making plaies, R. G. wisheth a better exercise, and wisdome to preuent his extremities". In this epistle Greene warns those whom he is addressing against trusting the actors for whom he had written plays and who have now deserted him in his poverty and illness. He calls the actors "those Puppets...that spake from our mouths, those Anticks garnisht in our colours". And he proceeds:

Is it not strange, that $\mathrm{I}$, to whom they all haue been beholding: is it not like that you, to whome they all haue been beholding, shall (were yee in that case as I am now) bee both at once of them forsaken? Yes trust them not: for there is an upstart Crow, beautified with our feathers, that with his "Tygers hart wrapt in a Players hyde", supposes he is as well able to bombast out a blanke verse as the best of you: and beeing an absolute Iohannes fac totum, is in his owne conceit the onely Shake-scene in a countrey....

The word "Shake-scene" obviously contains a reference to Shakespeare; and Malone interpreted the passage as a charge of plagiarism. He contended that

Greene and Peele were the joint authors of the two quarto plays... or that Greene was the author of one and Peele of the other.... [Shakespeare] having... probably not long before the year $1592 \ldots$ new-modelled and amplified these two pieces, and produced on the stage what, in the folio edition of his works, are called The Second and Third Parts of King Henry VI and having acquired considerable reputation by them, Greene could 
not conceal the mortification that he felt at his own fame and that of his associate, both of them old and admired playwrights, being eclipsed by a new upstart writer (for so he calls our great poet), who had then first, perhaps, attracted the notice of the publick by exhibiting two plays, formed upon old dramas written by them, considerably enlarged and improved.

The "Tygers hart wrapt in a Players hyde" is a modification of a line found in both The True Tragedie (I iv I 22) and 3 Henry VI (I iv I 37):

O tiger's heart wrapp'd in a woman's hide.

Malone's view was that Greene charges Shakespeare

with having acted like the crow in the fable, beautified himself with their feathers; in other words, with having acquired fame furtivis coloribus, by new-modelling a work originally produced by them [i.e. Greene and Peele], and wishing to depreciate our author, he very naturally quotes a line from one of the pieces which Shakespeare had thus re-written; a proceeding which the authors of the original plays considered as an invasion both of their literary property and character. This line, with many others, Shakespeare adopted without any alteration.

Apart from this and the "bad Quarto theory" there is yet another view of the relationship between the Contention Quartos and the Folio plays. Courthope ${ }^{\mathrm{I}}$ quotes Grant White, who reckoned that "more than 3400 lines in the Second and Third Parts of Henry VI are taken bodily from, or based upon passages in, The Contention and True Tragedy". This naturally led White to point out that "if Shakespeare stole all these, his undisguised appropriations brand him with a plagiarism without a parallel in literary history". This he considered "inconsistent alike with [Shakespeare's] established character for probity and the spontaneous fertility of his pen". So White evolved the

I See A History of English Poetry, vol. IV (1903), Appendix, pp. $455 \mathrm{ff}$. 
following hypothesis: Shakespeare, Greene, Marlowe, and possibly Peele, collaborated in writing the Ist Contention and True Tragedy for Pembroke's Company; later, when Shakespeare became exclusively connected with Strange's Company, he rewrote these plays, "rejecting the parts contributed by his former co-labourers, and retaining his own contributions, with such additions and amendments as might be expected from any writer upon the revision of a work produced in his earlier years of authorship". But Courthope thought that even on this hypothesis Shakespeare would be guilty of a plagiarism he found unthinkable -a "gross plagiarism of ideas". Furthermore, he thought Greene's language in his attack on Shakespeare far too mild to be taken as referring to plagiarism of this extent. To him Greene's words "naturally interpreted... seem to express the apprehension of a jealous rival who warns his associates that Shakespeare has copied the new blank verse style which they have introduced on the stage, and is likely to develop it in such a manner as to deprive them of their popularity". Anxious to absolve Shakespeare from any direct charge of plagiarism, Courthope is forced into the position of regarding the 1594 and 1595 Quartos as his own first drafts, which he subsequently revised into the texts found in the 1623 Folio.

But Dr Smart and Professor Alexander interpret Greene's words more convincingly than either Malone or Courthope. An attentive reading of the epistle cannot but result in the conclusion that the "upstart Crow beautified with our feathers" and the "Puppets that spake from our mouths, those Anticks garnisht in our colours" are in fact the same people, or rather that the upstart crow is one of the puppets or antics. There is a clear parallelism between the phrases "beautified with our feathers" and "garnisht in our colours"; and the word "feathers" itself suggests an actor. "Greene had a long-standing grievance against actors", says Professor Alexander, "and already in I590, 
in his Never Too Late, complained that the performer, who merely repeats the lines of an abler brain, makes far more than the author; and he addressed one individual in terms which are very similar to those employed in the letter:

Why Roscius, art thou proud with Esops Crow, being pranct with the glorie of others feathers? of thy selfe thou canst say nothing...."

The name "Roscius" shows clearly that it is an actor who is being addressed here. The imagery in both passages is the same, and so is the thought. The "upstart Crow beautified with our feathers" is obviously one of the same class as he who is "proud with Esops Crow, being pranct with the glorie of others feathers". In the attack on Shakespeare, Greene assails him as the actor who imagines himself able to turn author. The result is, of course, that the company to which such a one is attached will have less need to depend upon the "professional author" like Greene himself. Shakespeare is reviled as an actor who lives by speaking the lines of others and who wins all the applause, and more particularly as an actor who has the insolence to encroach upon the field of authorship itself; and Greene derisively adapts to his purpose one of Shakespeare's own lines, as much as to say "this is the sort of stuff the fellow turns out". Greene scorns the "upstart Crow.... with his "Tygers hart wrapt in a Players hyde""; the "his" refers both to the line itself and to the "hart", and the tone is contemptuous of the line. There is no charge of plagiarism at all, nor does Greene's outburst provide any obstacle against the "bad" Quarto theory, a theory which, as demonstrated by Professor Alexander, has won wide acceptance.

Tycho Mommsen ${ }^{\mathrm{I}}$ regarded these two Quartos in the same light as the first Quartos of Romeo and Fuliet and

I See Romeo und Fulia, eine kritische Ausgabe des überlieferten Doppeltextes, Prolegomena, pp. $15^{8-9}$. 
Hamlet; they are mutilated, deformed, and interpolated versions of the corresponding Shakespearian plays as given in the subsequently published authorized editions. Mommsen also realized that we must dismiss any theory of the development of Shakespeare's dramatic art which is based on a comparison of these spurious editions with the authentic ones on the assumption that the texts of the former antedate those of the latter. Professor Alexander's work shows that as far as the Henry VI Quartos are concerned Mommsen was right. Professor Pollard reiterates the same negation in his introduction to Alexander's book (p. 6). Further, as Pollard points out, against Malone, "as regards parallels and reminiscences and quotations from other plays which had recently been acted there is no reason to ask how these got into memorial reconstructions. From the very nature of the case a vamped text would be likely to contain phrases and even lines from other plays in which its authors had lately been acting." If the Ist Contention and True Tragedy are memorial reconstructions, we cannot argue from stylistic resemblances to the works of authors other than Shakespeare that these authors had a hand in their composition. It is impossible to lay too much stress on the importance of taking into account the manner of the transmission of the text in deciding the significance of passages found in a "bad" text and not in the corresponding authentic text. Perhaps the most flagrant error which has been made in this connection is that of F. S. Boas and J. M. Robertson, who profess to find in the first Quarto of Hamlet certain traces of the alleged Kydian Ur-Hamlet. Their main evidence for this view is the existence in the pirated text of a certain number of very close parallels to passages in undoubted works of $\mathrm{Kyd}$; $^{\mathrm{I}}$ indeed, most of these parallels are direct quotations or appropriations. It is curious that Boas should claim for $\mathrm{K} y \mathrm{~d}$ "inventive dramatic craftsmanship", ${ }^{2}$ while apparently maintaining that he was prone to

I See chapter vII, \$ I.

${ }^{2}$ See Boas, Works of Kyd, p. liv. 
write exactly the same speeches in similar situations in different plays. ${ }^{\mathrm{I}}$ Neither Boas nor Robertson pays sufficient attention to the problem of the nature of the transmission of the QI text. Once it has been established as a memorial reconstruction made by an actor or actors with or without other assistance, the true significance of these parallels appears obvious. Passages from other plays are transferred to this one, either deliberately, to fill in gaps caused by defective memory on the part of the reporter or reporters, or involuntarily, through memorial confusion between similar situations in different plays which are basically of the same type.

In the case of the ist Contention and True Tragedy, then, Professor Alexander has finally rejected the theories of Malone and Courthope. Furthermore, he regards these two texts as members of essentially the same class as that of Orlando Furioso, vamped up by a remnant of an acting company, lacking prompt-copy, and anxious to continue acting in the provinces. ${ }^{2}$ The main work was done by an actor who had played the part of Warwick in the full Shakespearian plays-his part is reported with a high degree of efficiency - and by an actor who had doubled the parts of Suffolk and Clifford, these parts being reported with a considerable degree of efficiency. Occasionally we find short passages which must have been transcribed from

I Similarly, The Taming of A Shrew (Q I 594) contains a considerable number of direct quotations from Marlowe, the existence of which enables us to dismiss from the outset the theory of Marlowe's authorship of that text, a theory advanced by Hickson (Notes and 2ueries, Ist series, vol. I, I 849-50, pp. I $94 \mathrm{ff}$. and $226 \mathrm{ff}$.), Fleay (Shakespeare Manual, i876, p. 186, postscript), and Robertson (Shakespeare Canon, vol. II, I 923 , pp. I 34 ff.). Sir Arthur Quiller-Couch suggests that Marlowe might have been guying his own bombast (The Nerw Shakespeare: The Taming of the Shrew, pp. xxii-xxiii): surely if he had wished to do so he would have managed it much more effectively.

2 For a discussion of the circumstances in which the memorial reconstruction was effected-a matter upon which there is still some debate-see, in addition to Alexander, The Nerw Shakespeare: The Taming of the Shrew, pp. 104 ff. 
some authentic theatrical manuscript. The vital point is that the texts were put together by actors, in all probability for use in provincial performance. Alexander makes out an excellent case, and another important fact is added to our knowledge of "bad" Quartos in general-Orlando is not a unique case: it is one example of a certain type of text, of which we also possess other examples. We may sum up by saying that the establishment of the Orlando class of "bad" Quartos is the most important development which has so far taken place in the study of pirated dramatic texts: individual members of the class may differ in detail, but the existence of the class is a fact.

Smart and Alexander would include The Taming of $A$ Shrew (Q I 594) in the same category. ${ }^{\mathrm{I}}$ This has not been received with quite such widespread approval as their treatment of the Contention plays. As regards the relationship between The Taming of A Shrew and the Shakespearian Taming of the Shrew (F), there are still three separate hypotheses in the field: (I) that $A$ Shrew is one of the "sources" of The Shrew; this was for long the general view, and it still has many adherents, notably Sir Edmund Chambers; ${ }^{2}$ (2) that $A$ Shrew post-dates The Shrew and is founded on it; associated with this view are the names of Hickson, Creizenach, Smart, Alexander, Dover Wilson, Van Dam, and Ridley; ${ }^{3}$ (3) that A Shrew and The Shrew

I See Smart, Shakespeare, Truth and Tradition (1928), pp. 20I-5; Alexander, Times Literary Supplement, r6 Sept. 1926; Shakespeare's "Henry VI" and "Richard III" (1 929); and Shakespeare's Life and Art (r939), pp. 69-7r.

2 See William Shakespeare, vol. I, pp. 322-8: see also R. Warwick Bond, The Taming of the Shrew, Arden ed., introduction (rst ed. 1904, 2nd ed. 1929).

3 See Hickson, Notes and 2ueries ist series, vol. I (1849-50), pp. 194, 226-7, 345-7; Creizenach, Geschichte des neueren Dramas, vol. IV (1909), pp. 686-98; Smart, Alexander, works cited; Dover Wilson, Nerw Shakespeare, Taming of the Shrew (1928), pp. $104 \mathrm{ff} . ;$ Van Dam, English Studies (Amsterdam), vol. x (1928), pp. 97 ff.; Ridley, Nerw Temple Shakespeare: The Taming of the Shrew (1934), introduction. 
are independently derived from a common source-play which is lost; this is the view of ten Brink and Hardin Craig. ${ }^{I}$ Upon no point is there anything like unanimity. One impressive piece of evidence in favour of hypothesis (2) was advanced as long ago as 1850 , when Samuel Hickson $^{2}$ noted in the two Shrew plays certain parallel passages in which the writer of $A$ Shrew has missed the point apparent only in the Shakespearian text. The natural inference is that in $A$ Shrew we have an attempt at reproducing The Shrew from memory. Hickson's evidence is confined to the main "taming" plot: none of his parallels occur in the subplot. But his argument for the priority of The Shrew is followed by that of Creizenach ${ }^{3}$ and Alexander, 4 who show that in certain respects the subplot of The Shrew stands nearer to the prose source-Ariosto's I Suppositithan does that of $A$ Shrew. They find it easier to believe that the writer of $A$ Shrew altered certain plot-elements in The Shrew than that Shakespeare based his play on $A$ Shrew and at the same time consulted I Suppositi, or rather Gascoigne's English version (Supposes, I 566). Chambers sees no obstacle to the latter theory: ${ }^{5}$ and the facts noted by Creizenach and Alexander might also be explained very neatly by hypothesis (3) - we might assume that Shakespeare had reproduced from the lost play plot-elements which the author of $A$ Shrew altered. The strongest evidence for the "bad" Quarto theory is certainly that of Hickson: not all of his parallels necessarily point to his conclusion, but some of them do, and these may legitimately determine the view we take of the others. The

I See B. ten Brink, Shakespeare Fahrbuch, vol. xIII (1878), p. 94; Hardin Craig, Shakespeare (1935), pp. 296-7.

2 Notes and 2ueries, ist series, vol. I, 1849-50, pp. 345-7.

3 Geschichte des neueren Dramas, vol. IV, pp. 686, 693-8.

4 Times Literary Supplement, 1926, p. 614.

5 William Shakespeare, vol. I, p. 328 . Chambers believes that in writing The Shrew Shakespeare had a collaborator and that it was this latter who was responsible for the subplot (op. cit. p. 324). 
problem is extremely complex, and a discussion cannot be undertaken here. I believe that $A$ Shrew is indeed a memorial reconstruction of some sort, and that certain portions of its prototype were close to the Folio text: I am not so sure that it is a direct reconstruction of that text, and the theory of ten Brink and Hardin Craig offers some distinct advantages. Suffice it here to state that the controversy exists, and to admit that $A$ Shrew has been very plausibly claimed as another member of the Orlando class of dramatic texts. The subject is still open.

\section{First Sketches or Debased Versions OF THE GOOD TeXTs?}

When we possess both a memorial reconstruction of a play and one or more authorized editions, we must be exceedingly careful of the inferences we draw from passages or characteristics peculiar to the former. The question in such cases (of which Hamlet is one) is, do the memorial reconstructions represent the plays as found in the authorized editions, or do they represent them at a distinct stage in their text-history? In other words, when we have to deal with a memorial reconstruction we must face the problem, of what is it a memorial reconstruction?

Before we accept any divergence between a memorial reconstruction and an authorized version of the same play as indicating that behind the former lies a stage of the play's history anterior to that given in the latter, we must be sure that the divergence in question did not arise in the process of the transmission itself. When it is remembered that a reconstructor's memory may fail and that in such a case he may attempt to supply the deficiency by his own invention or from some other source, the dangers of rushing at the above conclusion become apparent. Dr Greg's experience of the "bad" Quarto of The Merry Wives of Windsor has brought him to the conclusion that no limit 
can be set to the amount of corruption that a pirate may introduce into a reported text. ${ }^{I}$ Illustrations of what I have said can be offered from various types of divergence between "bad" texts and the corresponding "good" ones.

\section{(I) Inferiority of Reading}

All the Shakespearian "bad" Quartos contain scores of readings which are clearly inferior to the corresponding readings of the authentic editions. Are we to suppose that between the versions underlying the two sets of texts there stands a series of Shakespearian revisions in the course of which better readings were substituted for the original ones? Such an assumption cannot be made a priori, in view of the fact that defective memory may lead a reporter to substitute a commonplace word for a more vital one. The inadvisability of using inferiority of reading in "bad" texts as proof that these represent earlier versions than the authentic texts of the same plays is nowhere more strikingly exemplified than in Brinsley Nicholson's analysis of the Quarto of Henry $V$ from this point of view. ${ }^{2}$ $\mathrm{He}$ lists an imposing number of Quarto readings which are certainly poor when compared with those of the Folio, and springs to the conclusion that the Quarto represents a Shakespearian first sketch, without however noticing that many of these inferior readings are in fact reminiscences and anticipations of earlier and later passages in the play, introduced by memorial association during the course of the compilation of the Quarto text. I have space for only one or two examples of this error. Comparing I ii 170 in the two texts $(Q$ "To his vnfurnisht nest", $F$ "To her vnguarded Nest") Nicholson says " "unfurnisht' is a wrong epithet and 'unguarded' a right one, for the very

${ }^{1}$ See Modern Language Rervierw, vol. v (1910), p. 196.

2 Transactions of the Nerw Shakspere Society, 1880-2, Part I, pp. 77 ff. 
reason that draws the weasel is that the nest is furnisht with eggs". But he fails to notice that the Quarto reading results from a recollection of $\mathrm{I}$ ii $\mathrm{I} 48$, where the King refers to his grandfather's "unfurnisht Kingdome". That is to say, he fails to see that the Quarto variant has come about in the process of transmission. Similarly at r ii 94 Nicholson speaks of "the change of 'causes' to "Titles" : but the $Q$ reading "causes" is either a recollection of r i 8 I ff. ("causes. . . touching France") or an anticipation of II ii 59 ("now to our French causes"). I So, again, referring to I ii 242 , he asks "can there be a comparison between 'To whom our spirit is as subject' and 'Unto whose grace our passion is as subject'?" He considers the version of $Q$ that of a first sketch, ignoring both the metrical irregularity and the fact that spirit is an anticipation of I ii 254 (" $\mathrm{He}$ therefore sends you meeter for your spirit..."), which two points, taken together, themselves strongly suggest irregular transmission. At other points Nicholson sets down as Shakespeare's first draft passages in which the absolute breakdown of metre and structure make inept derivation from the Folio text very much more probable. Compare, for example, I ii $234-6$ in the two texts:

Q Now are we well prepared to know the Dolphins pleasure, For we heare your comming is from him.

F Now are we well prepar'd to know the pleasure

Of our faire Cosin Dolphin: for we heare,

Your greeting is from him, not from the King.

"In which are Henry's qualities of quick resolve, openness, and courtesy best shown?" asks Nicholson, suggesting that $Q$ represents a first sketch, $\mathrm{F}$ a revision. He fails even to mention the structural faults which point far more

${ }^{I} \mathrm{I} i$ is not represented at all in $\mathrm{Q}$. But this is probably a deliberate omission-a theatrical cut. 
strongly to imperfect representation of $\mathrm{F}$ than to the work of Shakespeare in his early period. Critics who argue in this manner seem to impute to Shakespeare a most extraordinary development from quite miserable ineptitude in his early days to complete perfection within comparatively few years.

At certain points Nicholson takes no notice even of the possibility of printing-house corruption. Compare the following two versions:

F King. Sure we thanke you.

My learned Lord, we pray you to proceed, And iustly and religiously vnfold,

Why the Law Salike....

(I ii IO-I3)

Q King. Shure we thank you. And good my Lord proceed Why the Lawe Salicke....

Nicholson's comment is: "Nor need I do more than call attention to the great verbal improvement of 'unfold', F., over 'proceed', Q., as the latter might merely imply that he [i.e. Canterbury] is to rehearse before the assembly arguments and conclusions as to which he and Henry were already in accord." Judging by the wording of this, one might imagine that Nicholson had failed to notice the word "proceed" in line I I of the Folio version: he has certainly failed to take into account the possibility that there is an accidental omission in $Q$ of the line "And justly and religiously unfold".

There is no need to give further examples of this defective argument. It is an extreme case perhaps; but it will serve admirably as a warning against similar argument in the case of this and other "bad" texts.

\section{(2) Non-Shakespearian Verse}

Some of the Shakespearian "bad" Quartos contain a certain amount of quite metrical verse which bears no 
direct relation to the corresponding passages in the authentic editions. This verse is often composed in a conventional and even archaic style nowhere used by Shakespeare even in his earliest plays. Is it then to be explained as belonging to a pre-Shakespearian stage of the text-history of the play concerned? Not necessarily; for as regards the first Quartos of Romeo and Fuliet and Hamlet Tycho Mommsen argued for the complicity of a hack-poet who supplemented the imperfect notes of a reporter by his own original composition. ${ }^{\mathrm{I}} \mathrm{Mr}$ H. R. Hoppe has shown that certain passages of verse peculiar to Q I Romeo are the work of an actorreporter, relying on his invention supplemented by his recollection of tags from other parts of the play and even from other plays. ${ }^{2}$ These passages are not part of a preShakespearian play. And in chapter IV of the monograph which follows I shall show that passages of verse peculiar to the first Quarto of Hamlet are to be similarly explained.

\section{(3) Characterization}

In the same way, it must be pointed out that where there is a difference in characterization between a memorial reconstruction and the corresponding authentic text this does not necessarily mean that a revision intervenes between the two texts. C. H. Herford points out that in the second Quarto and Folio versions of Hamlet the King is a much more complex character than in the first Quarto, where his guilt is portrayed crudely and directly, unmixed with the subtleties of characterization found in the authentic texts. Herford suggests that $Q$ I represents the first sketch, $Q_{2}$ and $\mathrm{F}$ the mature revised version: com-

The Athenaeum, vol. $\mathrm{xxIx}, \mathrm{1} 857$, p. 182 .

2 Review of English Studies, vol. xrv (1938), pp. 271-84. The passages dealt with are II vi and IV v $43 \mathrm{ff}$. Even more striking evidence of this type of composition is furnished by Q I V iii I $_{57-97}$ ("I am the greatest... rigor of the Law").

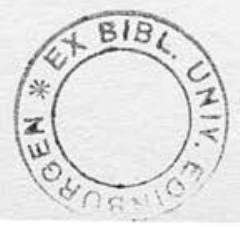


paring the two he speaks of Q2's "touches of the high art which allows no contrast to be too absolute; which relieves the unvaried shadows of the young painter with subtle half-lights, and tones down his glaring whites with delicate shade". I But the truth may lie in the opposite direction. To take this single example, we must balance the view that the Claudius of $\mathrm{Q}_{\mathrm{I}}$ is a less complex first attempt against the equally possible view that the change is from the character of $Q_{2}$ to that of $Q_{1}$ by deterioration. It is quite possible that a memorial reconstructor should be unable to appreciate or reproduce the subtle complexities of the Shakespearian characterization, and should simplify the character, thus producing the crude villany of the King in the first Quarto. Similarly with Hamlet himself. Herford and Furnivall make much of the fact that in $\mathrm{Q}$ he is much less individually philosophical, much more theologically orthodox, much simpler and less complex generally. But it is precisely the difficult philosophical reflections of the character found in $Q_{2}$ and $F$ that we might most expect a memorial reconstructor to be intellectually incapable of reproducing. And if the reconstructor were connected with the theatre (whether or not the reconstruction was made for acting) we should expect him to be interested in action rather than in reflection. Unless we find more definite corroboration of the theory that cruder characterization in a memorial reconstruction suggests dependence on a version anterior to that of the corresponding authorized edition or editions, we must be prepared to acknowledge the distinct possibility that the manner of the transmission of the former is itself sufficient to account for the difference.

\section{(4) Omission}

This is among the most difficult problems connected with pirated dramatic texts. Omission may result simply from

I Harness Prize Essay (1880), p. 40. 
defective memorial transmission. Alternatively, it may be due to deliberate excision in abridged acting versions. It is established that actors played a large part in the production of the extant memorial reconstructions. Naturally they would reconstruct the play as acted, which would not necessarily in all cases be identical with what appears in the authorized editions. Mr Alfred Hart distinguishes between these two types of omission in the Shakespearian "bad" Quartos. ${ }^{\text {I }}$ But thirdly, it may in certain cases be argued that passages not found in a memorial reconstruction are not strictly omissions at all, Shakespeare having added material during a revision of the text-basis of the memorial reconstruction. Speaking generally we may say that the absence from a memorial reconstruction of a passage found in the corresponding authentic text does not necessarily mean that that passage had not been written by the time when the reconstruction was made. And when we are persuaded that in a given case we have to deal with genuine omission in the reported text, it is generally extremely difficult to distinguish between omission due to defective memory in the reporter(s) and omission due to deliberate abridgement. ${ }^{2}$

Having attempted in this Introduction to sketch the position in which the study of "bad" Quartos finds itself at the present time, I propose to consider one example of this class of text in some detail, namely, the first Quarto text of Hamlet, published in 1603 . Since certain critics have

I Review of English Studies, vol. X (1934), pp. I-28, vol. XII (1936), pp. $18-30$.

${ }^{2}$ I have found positive indications of deliberate abridgement in the play underlying the Quarto of Henry V. In no other Shakespearian "bad" Quarto have I found omissions which can definitely and without any doubt be referred to abridgement and not to imperfect transmission. But this is because evidence is wanting; it does not mean that there was not abridgement. 
maintained that this text preserves in part a pre-Shakespearian play (the so-called Ur-Hamlet), and others that it preserves a Shakespearian first draft, it is necessary in the first place to consider and assess the value of the external evidence for the existence of these stages in the play's history. To this I proceed in the two following chapters. 


\section{CHAPTER ONE}

\section{THE EXTERNAL EVIDENCE FOR A PRE-SHAKESPEARIAN HAMLET}

No passage has been more often quoted in connection with Hamlet studies than that from Nashe's address "To the Gentlemen Students of Both Universities", prefixed to Greene's Menaphon, published in 1589, which runs:

But lest I might seeme, with these night-crowes Nimis curiosus in aliena republica, I will turne backe to my first text of Studies of delight, and talke a little in friendship with a few of our triuiall translators. It is a common practise now a dayes amongst a sort of shifting companions, that runne through euery Art and thriue by none, to leaue the trade of Nouerint, whereto they were borne, and busie themselues with the indeuours of Art, that could scarcely Latinize their neck verse if they should haue neede; yet English Seneca read by Candle-light yeelds many good sentences, as Blood is a begger, and so forth; and if you intreate him faire in a frostie morning, hee will affoord you whole Hamlets, I should say handfuls of Tragicall speeches. But O griefe! Tempus edax rerum, whats that will last alwayes? The Sea exhaled by droppes will in continuance bee drie, and Seneca, let blood line by line and page by page, at length must needes die to our Stage; which makes his famished followers to imitate the Kid in Aesop, who, enamoured with the Foxes newfangles, forsooke all hopes of life to leape into a newe occupation; and these men, renouncing all possibilities of credite or estimation, to intermeddle with Italian Translations: Wherein how poorely they haue plodded, (as those that are neither prouenzall men, nor are able to distinguish of Articles,) let all indifferent Gentlemen that haue trauelled in that tongue discerne by their two-pennie Pamphlets. And no maruell though their home borne mediocritie bee such in this matter; for what can bee hoped of those that thrust Elisium into hell, and haue not learned, so long as they haue liued in the Spheres, the 
iust measure of the Horizon without an hexameter? Sufficeth them to bodge vp a blanke verse with ifs and ands, and otherwhile for recreation after their Candle-stuffe, hauing starched their beards most curiously, to make a Peripateticall path into the inner parts of the Citie, and spend two or three howers in turning ouer French Dowdie, where they attract more infection in one minute, then they can do eloquence all daies of their life, by conuersing with any Authors of like argument. ${ }^{\text {I }}$

There are serious difficulties of interpretation here, and much diversity of critical opinion. We are mainly concerned with the following questions, which it is not always easy to keep apart from one another: (I) Is Nashe attacking a single person, or a group? (2) Is the Hamlet to which he alludes a drama? (3) Does the mention of "the Kid in Aesop" imply a reference to Thomas Kyd? (4) If the answers to questions (2) and (3) are both affirmative, is there any connection suggested between the Hamlet drama and Thomas Kyd?

\section{I}

Read literally, the passage must be regarded as an attack not upon an individual but upon a group of writers with common characteristics. Sarrazin and Boas thought otherwise, regarding it as a depreciation of Thomas $\mathrm{Kyd}$ and of him alone. "The use of the plural throughout by Nashe is evidently a mere rhetorical device", says Boas, ${ }^{2}$ "as so elaborate an indictment could only be aimed at a single personage." And here is Sarrazin:

Wenn auch Manches in diesen Anspielungen dunkel ist und vielleicht immer dunkel bleiben wird, so geht doch soviel zunächst mit ziemlicher Sicherheit daraus hervor, dass sie sich nicht auf mehrere, sondern auf eine einzige Person beziehen; denn es ist eine ganz einheitliche und individuell bestimmte Characterzeichnung, die darin entworfen wird. ${ }^{3}$

${ }^{1}$ McKerrow, Works of Nashe (1908), vol. III, pp. 31 5-16.

2 Works of Kyd (r $9 \circ \mathrm{r})$, p. xx.

3 Thomas Kyd und sein Kreis (1892), p. 1oo. 
Sarrazin proceeds to assert that the case is here the same as earlier in the same address, where Nashe refers to "vain glorious tragedians" and "idiot art masters": by this, says Sarrazin, Nashe "meint. . . nur Christopher Marlowe; der plural dient nur zur Verhüllung der persönlichen Angriffs". The most recent contributor to the discussion, Hr. V. $\phi$ sterberg, also inclines to the view that only one individual is attacked. ${ }^{\mathrm{I}}$

There is a good deal to be said on the other side, however. A. E. Jack ${ }^{2}$ asks why, if Nashe is condemning only Kyd, he should take the trouble to conceal the identity of the object of his satire under this cloak of plurality. "Certainly it was not his own native reserve", says Jack,3 "nor oversensitiveness at the pain he might cause another. Nor could it be, so far as we know, on social grounds, or financial, as these men belonged to rival theatrical companies. Moreover, savage attacks upon literary fellow-workers were then in vogue." Jack also points out that the earlier allusions to the "vain glorious tragedians" and "idiot art masters" need not be taken as referring only to Marlowe; they are equally applicable to Peele. There, too, the obvious interpretation is that Nashe is assailing a group.

The strongest point in favour of the plural interpretation is made by O. L. Hatcher ${ }^{4}$, who stresses the prima facie argument which generally exists for adopting the more obvious interpretation of a passage, and who rightly emphasizes words used by Nashe which cannot but signify the literal plural. He speaks of " $a$ few of our triuiall translators"; he attacks "a common practise now a dayes" among "a sort of shifting companions". All this seems very explicit. At the outset we must assume that in the passage quoted Nashe is satirizing a group of writers who shared to a certain extent the same characteristics.

I Studier over Hamlet-teksterne, vol. I (1920), p. I4.

2 Publications of the Modern Language Association of America, vol. $\mathrm{xx}$ (1905), pp. 729-48. 3 Op. cit. p. 733 .

4 Modern Language Notes, vol. Xxi (1906), pp. $177 \mathrm{ff}$. 


\section{II}

Who were these writers? Jack ${ }^{\mathrm{I}}$ holds that Nashe is attacking English translators of Seneca, inveighing against the inadequacy of their knowledge of Latin and consequently the poor quality of their translations. The critic paraphrases the passage in accordance with this interpretation. These hack-translators were intended by nature for mere clerical work, they are jacks-of-all-trades and masters of none; and, although they know little Latin, they betake themselves to scholarly tasks ("the indeuours of Art"). There follows an ironical commendation of their translations ("English Seneca") - they contain many good sentences like "Blood is a beggar", etc. This sentence itself need not be taken from the translations Nashe is attacking; it is merely an invented example. But the translations are really wretched-even the translators feel their work to be so poor that they realize that Senecan plays (whose authors draw on their translations) will soon pass out of vogue and there will be no market for the translations themselves. So the translators turn to Italian. Of course they are no better qualified for translation from that tongue: what can be hoped in this field from men who have transformed good Latin into wretched English (Jack understands in this figurative sense the words "thrust Elisium into hell"), and stupidly persist in translating Latin hexameters into English hexameters (they "haue not learned the iust measure of the Horizon without an hexameter")? They have no fine literary sense, and they are-content to patch up their verse with "ifs" and "ands"; nor are their morals better. ${ }^{2}$

Jack relates the passage under discussion to that which immediately follows it. Having gibed at his victims'

I Op. cit. pp. 742-8.

2 This interpretation is shared by Mrs C. C. Stopes: see Times Literary Supplement, 23 Jan. 1919 (p. 46). 
intimacy with "French Dowdie" Nashe proceeds: "But lest in this declamatorie veine, I should condemne all and commend none, I will propound to your learned imitation those men of import that haue laboured with credite in this laudable kind of Translation", and goes on to praise as translators Erasmus, Melanchthon, Sadolet, Plantine, and, in England, Eliot, More, and scholars educated at St John's College, Cambridge, "that most famous and fortunate Nurse of all learning". These are explicitly contrasted with bad translators who "beganne to vant their smattering of Latine in English impressions". Clearly, says Jack, Nashe turns from the "triuiall translators" whom he condemns to those distinguished translators from the classics whom he commends.

Consider the opening words of our passage: "But lest I might seeme, with these night-crowes [i.e. the MarPrelate pamphleteers] Nimis curiosus in aliena republica, I will turne backe to my first text of Studies of delight, and talke a little in friendship with a few of our triuiall translators." Let us look at the terms in which he treats of this first text earlier in the epistle:

I am not ignorant how eloquent our gowned age is grown of late; so that euery mechanicall mate abhorreth the English he was borne too, and plucks, with a solemn periphrasis, his $v t$ vales from the inke-horne: which I impute, not so much to the perfection of Arts, as to the seruile imitation of vaine glorious tragedians, who contend not so seriously to excell in action, as to embowell the cloudes in a speech of comparison, thinking themselues more then initiated in Poets immortality, if they but once get Boreas by the beard and the heauenly Bull by the deawlap. But heerein I cannot so fully bequeath them to folly, as their ideot Art-masters, that intrude themselues to our eares as the Alcumists of eloquence, who (mounted on the stage of arrogance) thinke to out-braue better pennes with the swelling bumbast of bragging blanke verse. Indeede it may bee the ingrafted ouerflow of some kil-cow conceit that ouercloyeth their imagina- 
tion with a more then drunken resolution, being not extemporall in the inuention of any other meanes to vent their manhoode, commits the disgestion of their cholericke incumbrances to the spacious volubilitie of a drumming decasillabon. Mongst this kind of men that repose eternitie in the mouth of a Player, I can but ingrosse some deep read Schoolmen or Grammarians, who, hauing no more learning in their skull then will serue to take vp a commoditie, nor Art in their braine then was nourished in a seruing mans idlenesse, will take vppon them to be the ironicall Censors of all, when God and Poetrie doth know they are the simplest of all. To leaue all these to the mercy of their Mother tongue, that feed on nought but the crums that fall from the Translators trencher, I come (sweet friend) to thy Arcadian Menaphon....

It is doubtful whether by "vain glorious tragedians" Nashe means actors or authors. ${ }^{2}$ By "Art-masters", however, he clearly means dramatists, for they "repose eternitie in the mouth of a Player". It is principally these dramatists that Nashe satirizes in the passage, and the occasion for the attack is the contrast between their bombastic pedantry and the "extemporall vaine" of his friend Greene. Further, these dramatists are among those who "feed on nought but the crums that fall from the Translators trencher"; presumably Nashe means that they are so ignorant of Latin that they make use of translations of the classics rather than of the classics themselves.

Let us now return to the passage first quoted, with which we are mainly concerned. Obviously its first sentence points back to the earlier passage just set out. Having satirized the Mar-Prelate pamphleteers, Nashe turns back to his "first text of Studies of delight" - that is, he proceeds once more to deal with literature meant for entertainment as opposed to these religious pamphlets. And his first text was more particularly an attack upon certain

I McKerrow, Works of Nashe, vol. IIr, pp. 311-12.

${ }^{2}$ Ibid. vol. rv, pp. 444-5. 
dramatists. Is Jack right in supposing that the "triuiall translators" of the later passage are the same men as the "Translators" mentioned at the end of the earlier one, and in supposing that Nashe, having in the earlier passage attacked dramatists who "feed on nought but the crums that fall from the Translators trencher", now turns his invective against these translators themselves? Or are the "triuiall translators" the dramatists whom he has already depreciated? If the latter hypothesis be upheld, we shall have to explain the transition from the "triuiall translators" to "those men of import that haue laboured with credite in this laudable kind of Translation", for these are certainly translators and not dramatists.

If we consider carefully certain parts of the passage relating to Hamlet we can hardly avoid the conclusion that Nashe has a group of dramatists in mind. "English Seneca" contains "whole Hamlets... of Tragicall speeches". If the attack is directed against translators of Seneca's plays, who were not practising dramatists, what can conceivably be the point of the gibe at Hamlet? Seneca wrote no Hamlet, and no Hamlet can have figured in any English version of his works. Mrs Stopes suggested that the reference is to a lost earlier edition of the prose Historie of Hamblet, translated from Book $\mathrm{v}$ of Belleforest's Histoires Tragiques: the first known English edition is of 1608 . But this is absurd: if Nashe is indicting incompetent English translators of Seneca who are not active dramatists, why should he deliberately drag in an allusion to a translation of a French prose tale? Let it be carefully noted that the reference to Hamlet is closely associated with that to "English Seneca". Jack's treatment of this point is not very full. Nashe means, he says, that in the English translations of Seneca "will be found either (I) characters much like Hamlet, or (2) plays as full of tragical speeches as either $(a)$ the well-known play of Hamlet, or $(b)$ the prose tale of Hamlet. The language is not sufficiently 
explicit to warrant a dogmatic statement." The fact that the reference is to "whole Hamlets of Tragicall speeches" renders hypothesis (2) much the more probable. Of the two alternatives mentioned in that hypothesis, $(b)$ faces us with the difficulty already noted-why in an attack on English translations of Seneca should Nashe pull in an allusion to a prose tale which has nothing to do with Seneca? The words "whole Hamlets" fit the context only if we suppose that the allusion is to a play of Hamlet, extant in 1589 and written on the Senecan model, although admittedly not directly based on any play of Seneca.

It seems virtually certain, then, that under the term "triuiall translators" Nashe includes, if indeed he does not designate, dramatists who write in imitation of Seneca. Nor is the passage lacking in corroboration of this view. Having declared that the "triuiall translators" have little knowledge of Latin, Nashe proceeds ironically: "yet English Seneca read by Candle-light yeelds many good sentences, as Blood is a begger, and so forth; and if you intreate him faire in a frostie morning, hee will affoord you whole Hamlets... of Tragicall speeches". Later, talking of these same "triuiall translators" he says that "otherwhile for recreation after their Candle-stuffe..." they go into the city to consort with "French Dowdie". The second of these sentences clearly implies that the "triuiall translators" do their work by candle-light, or in other words their work smells of the lamp. It is therefore safe to assume that the first implies that it is the "triuiall translators" who read "English Seneca" and filch material therefrom: it carries the same gibe about candle-light, and here Nashe is literally talking to the "triuiall translators" in accordance with his undertaking. Jack would have to suppose that the second personal pronoun referred to Nashe's own readers, and that he meant (ironically) that the work of the translators (in the literal sense) whom he is attacking was not bad in places. What then is the point of the reference to "candlelight"? Jack might say it carried as little significance as 
the phrase "in a frostie morning" - a meaningless phrase. ${ }^{\mathrm{I}}$ But is it not curious that the same reference is made, undoubtedly with significance, later in the passage, where it can only refer to the "triuiall translators" themselves? Obviously Nashe charges these "triuiall translators" with a lack of Latinity which constrains them (at least sometimes) to make use of English versions of Seneca rather than the originals. Who then can they be if not dramatists who write plays in the Senecan manner for the English stage? Addressing these men, Nashe says that English versions of Seneca will afford them "whole Hamlets" of tragic speeches: ${ }^{2}$ apparently a Hamlet drama had come from the pen of one of the group attacked, and according to the satirist's indictment its author was indebted for material to Seneca, whom however he could not read fluently in Latin. A point strongly in favour of this exegesis is that it is to exactly the same effect as Nashe's previous denunciation of dramatists who, with others, "feed on nought but the crums that fall from the Translators trencher" - a denunciation found in the earlier passage with which Nashe himself connects the one which we are discussing. One could call these dramatists "translators" in the usual sense if they pillaged Seneca in the original-and there is actually nothing in the passage to suggest that this was invariably beyond their power. But Nashe also uses the word in an extended sense - these dramatists plagiarize or "translate" Seneca at second hand, at least for the most part.

As a final suggestion of corroboration consider Nashe's declaration that "Seneca, let blood line by line and page by page, at length must needes die to our Stage". We have already noted Jack's interpretation of this: certain English translators of Seneca have done their work so badly that they themselves realize that dramatists who make use of their translations will cease to do so. I cannot regard this

I Cf. McKerrow's note.

2 This use of the phrase "Tragicall speeches" itself strongly suggests that the Hamlet referred to was a play. 
as a reasonable explanation. One of the most important elements in the gibe is the phrase "line by line and page by page". One would naturally expect a literal translator to work from one line to the next, from one page to the next. Surely Nashe is satirizing his victims for over-slavish dependence on Seneca. ${ }^{\mathrm{I}}$ In this case they must be dramatists. Not only their incompetence but their assiduity in rendering or imitating Seneca is going to result in this type of play passing out of popular favour-audiences will grow tired of it. This is the most direct interpretation of the sentence quoted; it is also what is clearly implied in the metaphor which Nashe brackets with it- "the Sea exhaled by droppes will in continuance bee drie." 2

One last point. From the "triuiall translators" Nashe turns to good translators (in the literal sense). These latter are contrasted with ignoramuses who "beganne to vant their smattering of Latine in English impressions". But these ignoramuses- "euerie priuate scholar, William Turner, and who not" 3 - are not the same people as the "triuiall translators" whom we have been discussing. The distinction is now simply that between direct translation of good and bad quality, though as he proceeds we find Nashe changing the issue by developing the contrast into that between good scholars and Puritan "Diuinitie Dunces". It seems that in praising "those men of import that haue laboured with credite in this laudable kind of 'Translation" Nashe thinks of them in general as classical scholars, and does not confine himself to translation pure and simple: in much the same way, I believe, in condemning the "triuiall translators" he is thinking not simply of literal translation

I I.e. presumably over-slavish dependence on "English Seneca".

2 The interpretation which I have given of the whole passage has been advanced by J. W. Cunliffe, in a refutation of Jack's theory: see Publications of the Modern Language Association of America, vol. XXI (1906), pp. 193-9.

3 Turner was a theological writer who excited Nashe's animosity, perhaps because of his Puritan views. See McKerrow's note. 
but of dramatists who imitate Seneca and borrow from him unashamedly, often not directly but from translations. It must be admitted that his use of the word "translators" is somewhat loose.

\section{III}

"The 'Kidde in Aesop'-", wrote Schick, " "this is indeed, I think, calling things by their names; surely Nash points here with his very finger to the person of $\mathrm{Kyd}$." $\mathrm{He}$ admits that there is no proof that Nashe is referring to $\mathrm{Kyd}$ and to no one else, but he claims that even apart from the alleged pun $\mathrm{K} y d$ fits the terms of the indictment better than anyone else.

To prove an allusion to $\mathrm{Kyd}$ in the passage, Sarrazin, Boas, and others have used two separate arguments: (I) that the remarks made by Nashe about the "triuiall translators" are particularly applicable to $\mathrm{Kyd}$; and (2) that the reference to "the Kid in Aesop" is an obvious pun. But when we remember that the passage is a diatribe against not one but a group of writers - a fact not recognized by Sarrazin and Boas - the first of these arguments appears as of but little value. For most of the accusations which are true of $\mathrm{K} y \mathrm{~d}$ might well be true also of many another who might belong to the group attacked.

Kyd's father was a scrivener; so, whether he himself followed "the trade of Nouerint" at any time or not, Kyd was certainly born to it. Sarrazin and Boas think that he might himself have been a scrivener for a time, suggesting that this would account for the presence in his works of a number of technical terms. In Sarrazin's own words: ${ }^{2}$

Ob er selbst [i.e. Kyd] diesen Beruf erwählt und nachher aufgegeben hatte, wissen wir nicht, können es aber wegen der Vorliebe für Prozess-Scenen und einiger juristischer Kunstausdrücke, wie "Ejectio firma", "sub-forma pauperis", vermuten.

${ }^{1}$ Edition of The Spanish Tragedy (1898), p. xvi.

${ }^{2}$ Thomas Kyd und sein Kreis, p. 100. 
And Boas ${ }^{\mathrm{I}}$ says that

Kyd, the scrivener's son, was certainly "borne" to the trade, and Nash seems to imply that he followed it for a time, before leaving it to "busie" himself "with the indeuours of art". This would account for the frequent use of legal terms and technicalities in his works. In the Spanish Tragedy, III xiii 59-66, "an action of Debt", "an action of the Case" and "an Eiectione firmae" are mentioned, and the documents required by the respective plaintiffs-a declaration, a "band", and a lease-clearly distinguished.

And he gives other examples. But Jack aptly replies that "the various attempts to show what trades and professions Shakespeare was probably an apprentice in, by citing his use of semi-technical words, must give us pause before the similar attempts of Sarrazin, Boas, and others to show that Kyd was probably himself a scrivener". ${ }^{2}$ After all, there is such a thing as general knowledge. And even if there is a reference to $\mathrm{Kyd}$, the meaning may simply be that being a scrivener's son he should in the normal course of things have become a scrivener himself, but rejected that profession for the more pretentious one of literature. In any case, however, we must take account of Nashe's plural, and consider the high probability that the statement is not intended to be taken literally at all: these fellows were equipped by nature only with the abilities appropriate to beggarly scriveners, and they have the presumption to meddle with higher things. Dr $\mathrm{McKerrow}^{3}$ tells us that elsewhere in his works Nashe refers "contemptuously to noverint-makers as if representative of the lowest class of work connected with the pen", and cites two examples: "Not a base Inck-dropper, or scuruy plodder at Nouerint, but..."4, and "some vnskilfull pen-man or Nouerint-

I Works of Kyd, p. xxi.

2 Op. cit. p. 735 .

3 Works of Nashe, vol. rv, p. $45^{\circ}$.

4 Ibid. vol. I, p. 240, lines $2-3$. 
maker".' "I see no reason", says Dr McKerrow, "for supposing any more special allusion in the present case than in these others." Besides, scriveners were as common as trees.

Again, it is true that $\mathrm{Kyd}$ wrote Senecan dramas, but so did other people. This was a common enough literary form at the time when Nashe was writing. The most we can say is that those whom he is attacking wrote Senecan dramas, and so did Kyd. Such a point can only serve as corroboration if a reference to $\mathrm{K} y d$ is proved by other means.

Thirdly, Kyd translated Tasso's treatise on household management under the title of The Householders Philosophie. This translation was published in $1588 .{ }^{2}$ " In 1588 ", says Boas, ${ }^{3}$ " $\mathrm{Kyd}$ appears to have given up, at least temporarily, his work for the stage, and to have leapt into the 'new occupation' of a translator from the Italian." Of the translation itself Boas says that it is "crowded with blunders, and fully deserves Nash's sneer.... at the 'home-borne mediocritie' of the translator". 4 The critic claims that this fact, revealed for the first time in the detailed comparison between the translation and the original in the notes to his edition of $\mathrm{K} y d$, "is a powerful new argument in favour of applying Nash's famous piece of invective to Kyd".5 McKerrow regards this as "certainly the strongest of the arguments in favour of Kyd" as an object of Nashe's attack, ${ }^{6}$ but warns us that it must be remembered that even if he was the translator of The Householders Philosophie, he was by no means the only translator from Italian. I should

${ }^{1}$ McKerrow, op. cit. vol. I, p. 341, lines 30-r.

${ }^{2}$ See Boas, op. cit. p. lxii, McKerrow, op. cit. vol. rv, p. 450. Jack erroneously dates it 1586 (op. cit. p. 737).

3 Op. cit. p. lxii.

5 Only the initials T. K. appear on the title-page, but the attribution is not in doubt: see Boas, pp. lxii-lxiii and McKerrow, vol. rv, p. 450 .

6 See also M. W. MacCallum, An English Miscellany (presented to Furnivall, I901), pp. 282-95. 
say that on the whole this would furnish fairly strong corroborative evidence of an allusion to $\mathrm{Kyd}$ if such could be established on direct evidence: but it certainly furnishes no more than that.

Boas, Schick, and Sarrazin find other particular references to $K_{y d}$ in the passage. Nashe says of the sort of writers he is scourging that they "thrust Elisium into hell". Boas, and before him Schick, saw an allusion to The Spanish Tragedy, ri 73, where Kyd "represents the 'faire Elizian greene' as one of the regions of the nether world beyond Acheron, and the abode of Pluto and Proserpine". I But, as both $\mathrm{Jack}^{2}$ and McKerrow ${ }^{3}$ point out, and as Boas ${ }^{4}$ admits, $\mathrm{K} y d$ is here following Vergil (Aeneid, vi, 440-702). The essential point is put by McKerrow: 5 why should Nashe object to Kyd's modelling his lower world upon Vergil's account, when upon Vergil was founded for many centuries the whole Christian conception of the after-world? We may perhaps add that, as Nashe is attacking, inter alia, ignorance of the classics, it is hardly suitable to denounce an author for using his Vergil. Boas is content to put this inconsistency down to the scurrilous exaggeration of the satirist: but in fact his argument is the nearest to absurdity which has been put in a mistaken attempt to relate everything in the passage to $\mathrm{Kyd}$. Is it not quite possible that here Nashe is talking quite figuratively - these fellows' minds present such a welter of unutterable confusion that they are quite capable of identifying irreconcilable opposites? We can appreciate this sense better if we understand an "as it were"they thrust heaven into hell, as it were.

Boas also regards the charge that they "haue not

I See Boas, Works of Kyd, p. xxix.

2 Op. cit. p. 739.

3 Op. cit. vol. rv, p. 450.

4 Op. cit. pp. 394-5.

5 Op. cit. vol. rv, p. 45 I. 
learned, so long as they haue liued in the Spheres, the iust measure of the Horizon without an hexameter" as a contemptuous reference to Kyd's use of the sixth book of the Aeneid in his description of the lower world in The Spanish Tragedy (I i $18-85$ ). ${ }^{\text {I I }}$ cannot but find this view incomprehensible. The same argument holds against it as against the last point: and in any case Boas does not explain the significance of the word "horizon". McKerrow ${ }^{2}$ suspects that the word "hexameter" may possibly refer to Latin verse, since Nashe uses it elsewhere in a general sense. ${ }^{3}$ But he rejects the suggestion that in our passage Nashe is referring to attempts at writing in classical metres in English. There was no especial interest in this subject in 1589; Nashe is not known to have been inimically disposed to anyone addicted to the practice-a practice indulged in by Greene in commendation of whom this epistle was written; again, "the movement was distinctively a 'learned' one, and in no way connected with the class of writers whom" Nashe "is attacking". 4 MacCallum suggests a pretty interpretation-Nashe's enemies "could not give the right quantity of the word without the scansion of a regular metre to guide them". 5 It may be another purely general sneer: these men are very ignorant-even their pronunciation is weak; in order to remember the correct pronunciation of the word "horizon" they have to run over in their heads a line of verse which contains it. This is mere conjecture, though eminently reasonable. But whatever be the solution to this puzzle and to the last, those put forward by Boas can hardly be correct.

The writers whom Nashe is depreciating "bodge vp a blanke verse with ifs and ands". Determined to find a

I See Boas, op. cit. pp. xxix, xlvi, 394-5.

2 Op. cit. vol. rv, p. $45^{\text {r. }}$.

3 McKerrow, op. cit. vol. I, p. 285 , line 35 .

4 Ibid. vol. IV, p. 45I.

5 An English Miscellany, p. 293. 
reference to Kyd in every charge made by Nashe, Sarrazin ${ }^{\mathrm{I}}$ took this as a thrust at the following passages:

And with that sword he fiercely waged war, And in that war he gave me dangerous wounds, And by those wounds he forced me to yield, And by yielding I became his slave.

(Spanish Tragedy, II i i 22-5)

If love's effects so strive in lesser things,

If love enforce such moods in meaner wits, If love express such power in poor estates....

(Ibid. III xiii 98-100)

But in neither passage is there any question of "bodging vp a blanke verse with ifs and ands": each exemplifies an intentional rhetorical device, of which the repetitions of "And" and "If" are but a part. ${ }^{2}$ Schick ${ }^{3}$ and Boas ${ }^{4}$ see a reference to the line

\section{What, Villaine, ifs and ands?}

(Spanish Tragedy, II i 77)

This reference is supported by Koeppel.5 McKerrow's criticism of it is unanswerable: "The expression ['ifs and ands'], which is common enough, occurs here with perfect propriety, and there is no question of 'bodging'. Nashe evidently refers to some padding with small unnecessary words, in order to eke out the metre, which was characteristic of the persons attacked." 6 It is not especially characteristic of $\mathrm{K} y \mathrm{~d}$.

Finally, Boas7 suggests that "when Nashe speaks of the

i Thomas Kyd und sein Kreis, p. ror.

${ }^{2}$ In any case Jack (op. cit. p. $73^{8}$ note) refers to no less than ten passages in dramas not by Kyd where successive lines begin with "and" or "if": he makes acknowledgement to F. G. Hubbard.

3 Ed. of Spanish Tragedy, p. xii.

4 Works of Kyd, p. xxix.

5 Englische Studien, vol. xvIII (1893), p. r 31 .

${ }^{6}$ Op. cit. vol. IV, p. 45 I.

7 Op. cit. p. xxix. 
authors who 'attract infection' by spending 'two or three howers in turning ouer French Doudie' he may be referring to Kyd's imitation in the Lord General's narrative (Spanish Tragedy, I ii $22 \mathrm{ff}$.) of the Messenger's account in Cornélie, Act v, of the battle of Thapsus". I This is quite ridiculous. Nashe leaves no doubt that here he is attacking not the writings of his enemies but their immoral lives. ${ }^{2}$

We find, then, that not one of the phrases which we have examined points directly at Thomas Kyd. One or two of them might possibly serve as corroboration of an attack on Kyd inter alios, if that could be shown from positive evidence to be intended. Identification of $\mathrm{K} y d$ as one of Nashe's victims must stand or fall by the allusion to "the Kid in Aesop".

Sarrazin, ${ }^{3}$ assuming that the allusion was to an Aesopic fable, and finding none to correspond with it exactly, concluded that Nashe had substituted a kid for an ape in order to achieve a pun on Kyd's name:

Keine der Aesopischen Fabeln, in welcher ein Zicklein oder Bock vorkommt, hat einen ähnlichen Inhalt; wohl aber ist in einer derselben von einem Affen die Rede, welcher den Fuchs wegen seines schmucken Felles und seines schönen Schwanzes beneidet. ${ }^{4}$ Nash hat also offenbar statt des Affen das Zicklein in die Fabel hinein escamotirt, um ein Wortspiel auf Kyd zu gewinnen.

Reviewing Sarrazin's book, Koeppel 5 showed that the story alluded to by Nashe comes, not from an Aesopic source, but from the May eclogue (especially lines 274-7)

I The reference is to Garnier's Cornélie. Garnier's collected works were issued in $15^{8} 5$.

${ }^{2}$ See MacCallum, op. cit. p. 293 and Jack, op. cit. p. 747.

3 Op. cit. p. roo note.

4 Sarrazin refers to Fabulae Aesopiae, ed. Camerarius, p. 221, and Phaedri Fabularum Aesopiarum Libri Quinque, ed. Müller, p. 68.

5 Englische Studien, vol. xvII, p. 130. 
in Spenser's Shepherd's Calendar. With Nashe's "Kid... enamoured with the Foxes newfangles" compare Spenser's lines:

Tho out of his packe a glasse he tooke,

Wherein while Kidde unawares did looke,

He was so enamored with the newell,

That nought he deemed deare for the jewell.

The verbal parallels in "enamoured" and "newfangles/ newell" make this derivation virtually certain. Thus Nashe's kid is not a substitution for another animal, and Sarrazin's argument collapsed. It should be noted, however, that critics who find no reference to Kyd in the epistle (Jack and McKerrow ${ }^{\mathrm{I}}$ ) admit that before this derivation turned up Sarrazin's argument for an allusion to $\mathrm{Kyd}$ was plausible. This admission will later assume importance.

McKerrow finds in works by Nashe two other passages which suggest that there is no particular reference in "the Kid in Aesop". First: earlier in the same epistle Nashe mentions another fable. Speaking of "our vnexperienced and illiterated Punies" he says that

a tale of Ioane of Brainfords will, and the vnlucky frumenty, will be as soone entertained into their Libraries as the best Poeme that euer Tasso eternisht: which, being the effect of an vndiscerning iudgment, makes drosse as valuable as gold, and losse as wel-come as gaine, the Glow-worme mentioned in Aesops Fables, namely the Apes folly, to be mistaken for fire; when as, God wot, poore soules, they haue nought but their toyle for their heate, their paines for their sweate, and (to bring it to our English Prouerbe) their labour for their trauell. ${ }^{2}$

"There happens to have been no writer of the name of "Glow-worm",", says McKerrow,3 "and therefore no

I See Jack, op. cit. p. 736; McKerrow, op. cit. vol. IV, p. $45^{\circ}$.

2 McKerrow, op. cit. vol. III, p. 3 I 4 .

3 Ibid. vol. IV, pp. 449-50. 
attempt has been made to give a personal application to the passage. Here, in a precisely similar way, he speaks of 'the Kid in Aesop'; is the fact that there happens to have been a person of the name of ' $\mathrm{K} y \mathrm{~d}$ ' any justification whatever for seeing in this case a personal allusion, when it is acknowledged that there is none in the other?" Secondly: Nashe himself complains that

in one place of my Booke, Pierce Penilesse saith but to the Knight of the Post, I pray how might I call you, \& they say I meant one Howe, a Knaue of that trade, that I neuer heard of before. ${ }^{I}$

These two passages indicate that there is not necessarily a personal allusion in "the $\mathrm{Kid}$ in Aesop". But we must set against them another passage, from Nashe's Anatomy of Absurdity, where he attacks men "who make the Presse the dunghill whether they carry all the muck of their mellancholike imaginations, pretending to anatomize abuses and stubbe vp sin by the rootes".2 The close association of the words "to anatomize abuses" and "stubbe" makes it quite certain that this is a sneer at Philip Stubbes, author of the Anatomy of Abuses. From McKerrow's evidence, then, we may say that there is not necessarily a personal allusion in the mention of "the $\mathrm{Kid}$ in Aesop": on the other hand, the latter may equally well be analogous to the passage just quoted. The problem remains where it was.

So far we have not found a single positive indication that Nashe is attacking $\mathrm{Kyd}$. But in the most recent contribution to the dispute $\mathrm{Hr}$. V. Østerberg submits an argument of great cogency. ${ }^{3}$ He shows that the Spenserian story of the fox and the kid is a most inappropriate one to apply to

I McKerrow, op. cit. vol. I, p. I54.

2 Ibid. vol. I, p. 20.

3 See Studier over Hamlet-teksterne, vol. I (1920), pp. 10-12. For synopses see a review in the Modern Language Review, vol. Xv (1920), pp. $43^{8-40}$, and The Nerw Shakespeare: Hamlet, pp. xviii-xix. 
the "triuiall translators" who have excited Nashe's animosity. Spenser's fable is of a kid who despite the previous warnings of his mother falls an innocent prey to a fox who comes to the door disguised as an indigent pedlar; the kid admits him, partly through compassion and partly because he is fascinated by a mirror which the fox displays to him; stooping to take a toy from the fox's basket, the kid is swept into it and carried off to be devoured. Thus the kid is destroyed through his naïvety and curiosity. Nashe applies this tale to writers who, having exhausted the possibilities of one literary pursuit, resort to another in order to maintain their livelihood. There is not the slightest similarity between the two cases: indeed, they present violent contrasts.

Østerberg's argument is impressive and bears development. It should be noticed first of all that there is a deliberate formal parallelism in the passage under discussion:

the Kid in Aesop

these men

who...f forsooke all hopes of renouncing all possibilities of life credite or estimation

to leape into a new occupation to intermeddle with Italian Translations

Consider the second of these parallel phrases. That in the right-hand column is literally applicable to the subject ("these men"): but that in the left-hand column is extremely clumsy. Admittedly the Kid forsook all hopes of life when he approached the fox's basket-but he did not know it: the Senecan dramatists, on the other hand, consciously decided that there was no further possibility of success in that field, and had recourse to another: furthermore, by changing their occupation they were entertaining distinct hopes of life in the form of a continuance of their income (precarious as it was-hence "his famished followers"). The analogy is very imperfect. 
But Nashe gives himself away completely in the third set of parallel phrases quoted. Again, that in the right-hand column is strictly applicable to "these men": but that in the left-hand one is totally inappropriate to the Kid, who cannot be said in any sense to have leapt into a new occupation. It was only "these men" who did that: the case of the Kid presents no parallel at all, and in forcing a parallel Nashe misrepresents the Spenserian fable nonsensically. In other words, starting with "these men" whom he is attacking, Nashe deliberately and very awkwardly wrenches the story of the Kid in order to make it appear analogous, though in reality it is not in the least so. The Kid (unconsciously) forsook all hopes of life and was destroyed through indulging his curiosity; the Senecan dramatists (consciously) tried to improve their position by changing their occupation. There is no connection whatever. On the whole Hr. $\varnothing_{\text {sterberg seems }}$ to me entitled to argue that Nashe has intentionally dragged in by the heels this extremely clumsy reference to "the Kid in Aesop"- - because he particularly desired a pun on the name of Thomas Kyd. Professor Dover Wilson supports this view, thinking that $\mathrm{Hr}$. $\varnothing$ sterberg has come very near to proving an allusion to $\mathrm{K}$ yd. ${ }^{\mathrm{I}}$

Mention was made earlier of the fact that Jack and McKerrow, who find no allusion to Kyd at all, admit that Sarrazin's argument for such an allusion had weight until disproved by Koeppel. ${ }^{2}$ Now $\varnothing$ sterberg's point is to essentially the same effect as that of Sarrazin-Nashe has done violence to the source of the fable on which he draws, and has done this simply in order to achieve the reference to $\mathrm{K} y d$. And Østerberg's argument actually springs from Koeppel's identification of the source of Nashe's fable.

I Nerw Shakespeare: Hamlet, p. xviii.

2 See p. 72 . 


\section{IV}

I would advance the following answers to the first three questions put at the beginning of this chapter: (I) Nashe is satirizing a group of writers, not a single individual; (2) these writers were dramatists, and the Hamlet mentioned was a play; (3) there is in all probability a personal allusion in the passage to Thomas Kyd. We come to the fourth question, which can be answered briefly, if also discouragingly. Inasmuch as Nashe is attacking more than one dramatist, we cannot assume that $\mathrm{Kyd}$ was the author of the Hamlet play. There is nothing in the passage which suggests this direct connection between the "whole Hamlets of "Tragicall speeches" and "the Kid in Aesop". The most we can say is that a Hamlet was written by a member of the group of authors under Nashe's fire, and that Kyd was probably a member of this group. He may indeed have been responsible for the play, but Nashe cannot be cited as proving it.

\section{Other Allusions}

In a list of performances given at Newington Butts in June 1594 by "my Lord Admeralle men and my Lorde Chamberlen men", Philip Henslowe's diary contains the record of a performance of a Hamlet play (June 9, properly June II). It is Henslowe's practice to mark as "ne" a play of which he is recording the first performance. This Hamlet is not so marked. It is thus too early for us to suppose it Shakespearian or even partly so. We must infer that this was a revival of the old Hamlet to which Nashe refers in 1589. And even critics who doubt that Nashe alludes to a play on the subject of Hamlet must admit the force of Henslowe's evidence that such a play existed in the early nineties at all events. Again, in his Wit's Miserie (I596) Lodge has a Hamlet reference in the words "as pale as the Visard of ye ghost which cried so miserably at ye 
Theator, like an oister wife, Hamlet, revenge". In none of the extant dramatic texts does the Ghost use these words. One might suggest that Lodge is simply epitomizing. But this is ruled out by the fact that there are two later references to Hamlet in which the same cry is used. ${ }^{I}$ Apparently the Ghost actually used the words "Hamlet, revenge" in the old play, and the phrase seems to have caught the contemporary and nearly contemporary imagination. Further, the allusions to it are derisive. In the Satiromastix Tucca says to Asinius "my name's Hamlet revenge". This play was probably performed in the latter part of I60I; and we are safe in assuming that the reference cannot be to a Hamlet Shakespearian in whole or in part, since presumably Shakespeare's work would not be ridiculed by his own company in his own theatre. ${ }^{2}$

We are certainly justified in concluding from all the allusions we have noted 3 that there was a pre-Shakespearian Hamlet play, and we can proceed to an examination of the first Quarto text with that knowledge, which will prove to be relevant.

${ }^{1}$ Dekker, Satiromastix, IV i 150 (1601), and Rowlands, NightRaven, sig. $\mathrm{D}_{2}$ (1620).

2 See H. D. Gray, Philological 2uarterly, vol. vII (1928), pp. 255-6.

3 In Robert Armin's Nest of Ninnies ( 1608 ) we find the sentence "Ther ar, as Hamlet saies, things cald whips in store". But this does not provide evidence for a pre-Shakespearian Hamlet. In all probability Armin attributed the remark to Hamlet in error, having in mind Hieronimo's words in the additions to the Spanish Tragedy:

And there is Nemesis, and Furies,

And things called whippes,

And they sometimes doe meete with murderers:

They doe not alwayes scape, that is some comfort.

(Boas, Works of Kyd, p. 6o.)

This was first pointed out, as far as I know, by A. C. Lee (Notes and 2ueries, 7 th series, vol. vI (1888), p. 84 ). Armin may have confused the passage with Hamlet's reference to "the whips and scorns of time" (III i 70). 


\section{THE EXTERNAL EVIDENCE FOR A SHAKESPEARIAN FIRST DRAFT}

The earliest known reference to a Shakespearian Hamlet occurs in a long manuscript note written by Gabriel Harvey in his copy of Speght's edition of the works of Chaucer, published in 1598. The note consists of a review of contemporary literature and literary taste, and contains the following observation: ${ }^{\mathrm{I}}$

The younger sort take much delight in Shakespeares Venus and Adonis, but his Lucrece and his tragedy of Hamlet Prince of Denmarke have it in them to please the wiser sort.

We know that Harvey acquired his copy of Speght in the year of its publication, for he inscribed his name and the date on the title-page and after the word "Finis". ${ }^{2}$ But, as has been more than once pointed out, it does not follow from this alone that the note with which we are concerned was written in that year. It may be later.

Professor Moore Smith discusses the note in the preface to his edition of Harvey's marginalia. ${ }^{3}$ There we find an account of Malone's views on its bearing upon the dating of Shakespeare's Hamlet. In a letter to Bishop Percy ( 1803$)$ Malone points out that in the note Spenser is grouped among "our flourishing metricians". Spenser died in January $1598 / 9$, so the note must have been written in

I The note appears on folio 394 verso of the volume, and is printed on pp. 232-3 of G. C. Moore Smith's Gabriel Harvey's Marginalia ( 1913$)$ :

2 Title-page: "gabriel haruey. I 598 ". After "Finis": "gabrielis harueij, et amicorum. I598”. See Moore Smith, op. cit. pp. 226 and 233 .

3 Pp. viii-xii. 
I 598, and Shakespeare's Hamlet must date to before that year.

But in a second letter to Percy (also 1803) Malone expresses a different view. He takes the phrase "our flourishing metricians" to mean, not, as before, those now alive, but those now held in esteem. For Thomas Watson, the author of Hecatompathia, also named among the "flourishing metricians", died in I 592. Thus the note may have been written after Spenser's death. ${ }^{\mathrm{I}}$

F. S. Boas ${ }^{2}$ notes that Harvey had been on terms of personal intimacy with Thomas Watson. It is hardly likely that he would think him still alive at some time in I 598 or later. Sir Herbert Grierson ${ }^{3}$ thinks it an accidental error: but it is very odd. Unless we are prepared to believe that Harvey could perpetrate this blunder, we must interpret the phrase "our flourishing metricians" as referring not to living poets but to those, living and dead, who are in vogue. In any case the fact that the phrase could bear this interpretation makes it dangerous to use it in establishing January I 598/9 as the terminus ad quem for the date of the note.

In his Life of Shakespeare (I9I5 ed.) Sir Sidney Lee dates the note as late as I606. For Harvey refers to John Owen's Latin Epigrammata: "I haue a phansie", he says, "to Owens new Epigrams".4 These were first published in 1606 . But, as both Boas ${ }^{5}$ and Grierson point out, poems were frequently circulated in manuscript long before they were printed. One of these very epigrams, addressed to Lord Burleigh, is dated $1596 .^{6}$ Boas mentions manu-

I In his edition of Hamlet Malone suggests that it may have been written towards the end of 1600 : Works of Shakespeare, 1821, vol. II, p. 369 .

${ }_{2}$ Shakespeare and the Universities (1923), p. $25^{8}$.

3 In a review of Moore Smith's edition of the marginalia: Modern Language Revierw, vol. XII (I9r7), pp. 220-r.
4 Moore Smith, p. 233.
${ }^{6}$ Moore Smith, p. 309.
5 Op. cit. p. 257 
script poems actually alluded to by Harvey in the same note - Raleigh's Cynthia and Sir Edward Dyer's "written deuises" which excel "most of the sonets, and cantos in print". Grierson mentions examples of manuscript circulation in the case of other poets-Davies and Donne. In view of this I cannot quite understand Sir Edmund Chambers's reluctance to accept this explanation here. ${ }^{\mathbf{I}}$

Lee's dating of the note, then, is unnecessarily late, and it involves some more than questionable manipulating. For the note refers to the Earl of Essex in the present tense. "The Earle of Essex", says Harvey, "much commendes Albions England." 2 Essex was executed in February I60I; so Lee is forced to argue that "commendes" is a historic present. ${ }^{3}$ Grierson 4 remarks that there is no parallel to this usage in connection with a man who had died so recently and under such dramatic circumstances; and Boas concurs. 5 There can be little doubt that I 598 is the terminus a quo and the beginning of I6OI the terminus ad quem for the dating of the note.

In this same note Harvey refers to "translated Tasso". If by this he meant, as Malone thought, the complete translation by Fairfax ( 1600 ) of the Gerusalemme Liberata, then we are obliged to date the note $1600-$ between the appearance of Fairfax's work and the death of Essex in February I60I - as Malone did in his edition of Hamlet. But Richard Carew's translation of the first five cantos of Tasso's poem appeared in 1594, and Abraham Fraunce's translation of the pastoral play Aminta in I591. So "translated Tasso" need not be Fairfax's version.

It is safe to place the note between I 598 and the beginning of I601. A reference which it contains to Lord

I William Shakespeare, vol. Ir, p. 197.

2 Moore Smith, p. 232.

3 Life of Shakespeare (1915), p. 360 note.

4 Op. cit. p. $22 \mathrm{I}$.

5 Op. cit. p. 259 note. 
Mountjoy serves only to date it before 1603 . Having noted Essex's commendation of Warner's poem (Albion's England) Harvey goes on to say that "the Lord Mountjoy makes the like account of Daniel's peece of the Chronicle, touching the Vsurpation of Henrie of Bullingbrooke", that is Daniel's First Fowre Bookes of the Civile Wars between the two Houses of Lancaster and Yorke (1595). Mountjoy went to Ireland as Lord Deputy early in 1600 , replacing Essex in that position. He stayed there for three years, and on his return to England in 1603 was created Earl of Devonshire. Had the note been written after 1603 he would almost certainly have been referred to by his new title, for the Elizabethans were very punctilious about titles. ${ }^{\mathrm{I}}$ Boas is doubtless right in supposing that "Harvey is recording a commendation of Daniel's Civil Wars by Mountjoy before he left England early in I600", but it does not follow that the note itself was written while Mountjoy was still in England. We cannot therefore use this allusion to pull back the terminus ad quem to the beginning of 1600 .

Can we fix the date of the note to a point within our termini? Sir Herbert Grierson ${ }^{2}$ argues in favour of dating it 1598 . It contains a long reference to one "Axiophilus" and his dreams of literary reputation: 3

\& amongst so manie gentle, noble, \& royall spirits meethinkes I see sum heroical thing in the cloudes: mie soueraine hope. Axiophilus shall forgett himself, or will remember to leaue sum memorials behinde him: \& to make an vse of so manie rhapsodies, cantos, hymnes, odes, epigrams, sonets, \& discourses, as at idle howers, or at flowing fitts he hath compiled. God knowes what is good for the world, \& fitting for this age.

Moore Smith 4 identifies Axiophilus with Harvey himself, and Grierson and Boas agree. Now Grierson notes the

I Grierson, op. cit. p. 22 I.

3 Moore Smith, p. 233.

$\mathrm{DB} Q$
2 Ibid.

${ }^{4}$ Op. cit. p. 306. 
apparent close connection between the above extract and a letter from Harvey to Sir Robert Cecil, dated May 8,

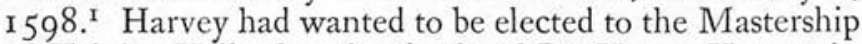
of Trinity Hall after the death of Dr Henry Harvey in February I $584 / 5$ : but Thomas Preston was elected. ${ }^{2}$ Immediately after Preston's death, or indeed while he was dying, ${ }^{3}$ Harvey wrote this letter to Cecil, referring to the manner of his rejection thirteen years before and begging his assistance towards obtaining the position now. He includes an extended testimonial to his own scholarship, and mentions the honour he has previously paid in his writings to those whose favour he now solicits: 4

Some men would haue used more plausible means of insinuation to my good Lord Treasurer, that have not written half so much in honour of his weighty \& rare virtues, as I can impart at your leisure for the perusal of such exercises. But I sought but his honour \& fame: as I did in sundry royall cantos (nigh as much in quantity as Ariosto) in celebration of her Majesty's most glorious gouernment, some of them deuised many years past at the instance of the excellent knight and my inestimable dear friend Sir Philip Sidney, some since the renowned victory in '88, which, neuertheless, I intended not to publish in the lifetime of the Queen, had not some late prouoking occasions enforced an alteration of my purpose:... Now if my good Lord Treasurer or yourself shall not disallow of them, it imports me to bestow a little time in the transcripting and reforming of them, \& to publish them, with other tracts and discourses, some in Latin, some in English, some in verse, but much more in prose....

Thus in 1598 Harvey was contemplating the publication of his works, including "sundry royall cantos" and "other tracts and discourses": and in the note under discussion he also refers to his unpublished work, including cantos

I Moore Smith, pp. 72-4.

2 Ibid. pp. 46-9.

3 "Dr Preston, the master of that Hall, is either now dead or past hope of recouery" (from the 1598 letter: Moore Smith, p. 73).

${ }_{4}$ Moore Smith, pp. 73-4. 
and discourses, implying that he will publish them, thus leaving "sum memorials behinde him". From this similarity Grierson argues that the note was written about the same time as the letter, that is, in 1598 . The point is by no means unimpressive, but the evident connection between the two passages does not necessarily point to this conclusion. Harvey did not carry out the promise contained in the letter, but it is possible that some years later he still intended to do so and again referred to this intention in similar terms.

Grierson and Boas mention another argument in favour of dating the note 1598 . They regard it as contemporaneous with another note ${ }^{I}$ in which Harvey refers to "M. secretarie Cecill, the new patron of Chawcer", an allusion to the fact that Speght had dedicated his edition to Cecil. Boas argues ${ }^{2}$ that this reference would only have point very shortly after the appearance of the volume. I cannot think of this as a very strong argument: in any case it is doubtful whether the grounds for regarding the two notes as contemporaneous are adequate. Admittedly they are distinctly similar in tone: both link references to "Axiophilus" with references to the work of other poets and allude to the former's slowness to publish. But here also it is unnecessary to believe that the presence of this idea in Harvey's mind was confined to one particular time.

Summing up the evidence, the most we can say is that the note with which we are concerned was written before February I60I; there is just a possibility that its date is I 598.3 Now in the final Shakespearian play there are passages which cannot have been composed before the

I On folio 393 verso of the copy of Speght: see Moore Smith, p. 231.

2 Op. cit. p. 259.

3 The non-appearance of a Hamlet in Meres's carefully balanced list of six comedies and six tragedies of Shakespeare (Palladis Tamia, r598) does not necessarily mean that he had not handled the play. It is quite clear from Meres's words that he is only giving instances of Shakespeare's work. 
latter part of I60I-the reference to the "little eyases" and the Wars of the Theatres in II ii 340-65, and the allusion in IV iv I 8 to the English defence of Ostend (July I60I to the spring of I602). ${ }^{1}$ If there was a Shakespearian or partly Shakespearian Hamlet extant at the beginning of $160 \mathrm{I}$ (or conceivably in 1598 ) it cannot have been the play exactly in its final state-though apart from the two passages mentioned there is nothing to indicate how great the difference may have been: an extensive revision may have intervened, or simply the addition of one or two passages - and the latter suggestion is as probable as the other. All that we can say is that Harvey's note makes it possible for us to believe that there may have been a stage in the text-history of Hamlet which could be described as a Shakespearian first draft; and this possibility is of interest to us in view of the fact that certain critics maintain that, although the QI edition was published after the play had assumed its final form in Shakespeare's hands, it nevertheless presents the text of that first draft.

${ }^{1}$ II ii $340-65$ is wanting in $Q_{2}$. But that it cannot have been written after the publication of that edition is clear: it was obviously written when the Wars of the Theatres were at their height, and is an omission from $\mathrm{Q}_{2}$. See Dover Wilson, Manuscript of Shakespeare's "Hamlet", vol. I, p. 97. Again, IV iv 9-66 is omitted in F 1 -obviously a theatrical cut: see Dover Wilson, op. cit. pp. 30-1. Both passages stood in the final Shakespearian version preceding the publication of $\mathrm{Q}_{2}$. 


\section{THE FIRST QUARTO OF HAMLET: THE MAIN CONTROVERSY}

Since the discovery of the 1603 edition of Hamlet by Sir Henry Bunbury in $1823,{ }^{1}$ Shakespearian criticism has been agitated by the problem of what stage of the play's evolution underlies the text of that edition. The question is still debated without very much general agreement. Broadly speaking there are two main hypotheses: (I) that behind $Q_{1}$ lies a version of the play anterior to that given in $Q_{2}$, and (2) that the QI text is based solely on the version found in $Q_{2}$, variations from the latter post-dating it. But there are differences of opinion even within each of these two general theories.

\section{I}

The hypothesis that QI represents a version of the play distinct from and anterior to that given in $\mathrm{Q}_{2}$ may itself be subdivided into two separate theories.

(I) The copy discovered by Bunbury was reprinted for and published by Payne and Foss in I 825 . In a prefatory note the text is described as that "originally written by Shakespeare, which he afterwards altered and enlarged". This, the first extant critical opinion of the text, was the view of most of the earlier critics-Singer, Caldecott, Knight, Hunter, Elze, Timmins, Gervinus, Staunton, Delius, and Dyce. ${ }^{2}$ Others who maintain the same position

${ }^{1}$ Another copy was discovered in 1856 , lacking the title-page. That discovered in 1823 lacks the last leaf, containing the last stagedirection and the last twenty-two lines of the text.

${ }^{2}$ For references and synopses see H. H. Furness's New Variorum edition of Hamlet (1877), vol. II, pp. 14-24. 
include Furnivall, George MacDonald, Swinburne, and Dowden. ${ }^{\mathrm{I}}$

(2) Attention having been fixed upon the fact of the existence of a pre-Shakespearian Hamlet play, a more complex hypothesis was developed, the QI text being regarded as representing a transition play, intermediate between the old Hamlet and Shakespeare's final version (Q2). According to this hypothesis, the version underlying QI was the early play partially revised by Shakespeare: the full revision underlies the $\mathrm{Q}_{2}$ text. This view is maintained by W. G. Clark and W. Aldis Wright, W. H. Widgery, C. H. Herford, John Corbin, F. S. Boas, J. C. Allen, J. M. Robertson, J. Dover Wilson, G. B. Harrison, E. E. Stoll, and T. M. Parrott and Hardin Craig. ${ }^{2}$ W. J. Lawrence believes that the QI text is based directly

I Furnivall, introductions to W. Griggs's facsimiles of $Q_{1}$ and $Q_{2}$, I 880; MacDonald, The Tragedie of Hamlet, Prince of Denmarke, 1885 , republished 1924; Swinburne, Study of Shakespeare, p. 16r; Dowden, Arden edition of Hamlet, first published 1899, pp. xvii-xix. See also Edinburgh Review, vol. LxxxI, pp. 378 ff. (anon.); T. RochfortSmith, Transactions of the Nerw Shakspere Society, r880-5, Part II, pp. 50-1; E. Deckner, Normannia, vol. IV (1909, Berlin).

${ }^{2}$ Clark and Wright, Hamlet (Clarendon Press, 1872), pp. viii ff.; Widgery and Herford, Harness Prize Essays, 1880; Corbin, Harvard Studies and Notes in Philology and Literature, vol. v (1896), pp. 24560; Boas, Works of Kyd, rgor, introduction pp. xlv-liv; Allen, Westminster Revierw, vol. cLxx (1 908), pp. 551-64, 684-92; Robertson, The Problem of "Hamlet", 1919; Dover Wilson, The Library, 3 rd series, vol. IX (1918), pp. 153-85, 217-47, and, with A. W. Pollard, Times Literary Supplement, 1919, pp. 18, 30; Harrison, Bodley Head reprint of QI, 1923, pp. xxviiiff.; Stoll, Modern Philology, vol. xxxv (1937-8), pp. 3 Iff. and vol. xxxvII (1 939), pp. I 73 ff.; Parrott and Hardin Craig, Hamlet: Second 2uarto (1938), pp. $26 \mathrm{ff}$. Cf. also H. de Groot, "Hamlet", its Textual History (1923); de Groot does not however regard the text of $Q_{I}$ as a piracy. In this he agrees with F. G. Hubbard (Wisconsin University Studies in Language and Literature, 1920; Modern Language Notes, vol. xxxir, 1918, pp. 73-9; Publications of the Modern Language Association of America, vol. XxxviII, 1923, pp. 792 ff.). 
on that of the old Hamlet, but contains certain infiltrations introduced by the reporter from the full Shakespearian play. ${ }^{I}$

\section{II}

The second main hypothesis postulates that the QI text is founded on that given in $\mathrm{Q}_{2}$. Features peculiar to $\mathrm{QI}_{\mathrm{I}}$ post-date the $\mathrm{Q}_{2}$ text, and may be the result of either of two factors-imperfect reporting or deliberate alteration.

The first critic to advance the theory that QI represents a version of the play essentially the same as that of $\mathrm{Q}_{2}$ was Collier. ${ }^{2}$ He argued that the greater part of the Q $\widetilde{Q}_{\text {text }}$ was transmitted by a stenographer, and suggested that where his notes were defective he either filled the gaps badly from memory or obtained assistance from an "inferior writer". The theory that a third-rate poet patched the holes in an imperfect report of a version of the play not essentially different from that of $\mathrm{Q}_{2}$ is also associated with the names of Tycho Mommsen, Wilhelm Creizenach, and H. D. Gray. ${ }^{3}$ Creizenach agrees with Collier that the reporting was stenographic. Mommsen suggested that the reporter was probably "an actor, who put down from memory a sketch of the original play as it was acted, and who wrote very illegibly". Gray identifies the pirate-actor as having played the parts of Marcellus and Lucianus: he believes that while $Q$ I represents a text essentially the same as that of $Q_{2}$, there was a stage of revision, not extensive, between.

Three critics who hold hypothesis II assert emphatically that the $\mathrm{Q}_{1}$ text not only post-dates that of $\mathrm{Q}_{2}$, but

I Shakespeare's Workshop, 1928, pp. 110-23.

2 Edition of Shakespeare, 1843 , vol. vir, introduction to Hamlet, p. I9r.

3 Mommsen, The Athenaeum, vol. xxrx, 1857, p. 182; Creizenach, Shakespeare Fahrbuch, vol. XLII (1906), pp. 76-85; Gray, Modern Language Revierw, vol. x (1915), pp. $17 \mathrm{r}$ ff., and Publications of the Modern Language Association of America, vol. XLII (1927), pp. $721 \mathrm{ff}$. 
represents a deliberate stage-adaptation of that text. Alterations of the $\mathrm{Q}_{2}$ text in this stage-adaptation are stressed by William Poel and R. Crompton Rhodes. ${ }^{\mathrm{I}}$ Abridgement is also postulated, a subject with which Alfred Hart is especially concerned, maintaining that the reporter was an actor who had taken part in an official abridgement of the $\mathrm{Q}_{2}$ text. $^{2} \mathrm{~F}$. P. von Westenholz does not regard $Q_{I}$ as giving a pirated text; but he considers that its text post-dates that of $Q_{2}$ and represents an abridged adaptation of it made for a provincial tour. ${ }^{3}$

Amongst other critics who hold that the QI text depends upon that of $Q_{2}$ are Gustav Tanger and B. A. P. Van Dam. ${ }^{4}$ Both regard $Q_{I}$ as giving a shorthand report. Tanger emphasizes the responsibility of the stenographer for the majority of the differences between $Q_{1}$ and $Q_{2}$; Van Dam attributes a great proportion of these to the actors.

The view that the $\mathrm{Q}_{1}$ text post-dates that of $\mathrm{Q}_{2}$ is also that of R. Grant White, E. K. Chambers, Giovanni Ramello, and V. Østerberg.5

Before they evolved the hypothesis voiced in their Clarendon Press edition of Hamlet, ${ }^{6}$ Clark and Aldis

I Poel, Notes and 2ueries, 12 th series, vol. XI (1922), pp. 30I-3; Rhodes, Shakespeare's First Folio, 1923, pp. 72-83.

${ }^{2}$ Revierw of English Studies, vol. X (1934), pp. 1-28, vol. XII (1936), pp. 18-30; also the chapter on play-abridgement in Shakespeare and the Homilies.

3 Englische Studien, vol. xxxrv (1904), pp. 337-50.

4 Tanger, Transactions of the New Shakspere Society, 1880-2, Part I, pp. 109-97; Van Dam, The Text of Shakespeare's Hamlet, 1924, chap. $\mathrm{r}$.

5 White, Introduction to Hamlet, edition of $186 \mathrm{r}$, pp. roff.; Chambers, William Shakespeare, vol. I (1930), pp. 4r2 ff.; Ramello, Studi sugli Apocrifi Shakespeariani: Hamlet, I603 (1930); $\emptyset_{\text {sterberg, }}$ Studier over Hamlet-teksterne, I (Copenhagen, 1920), and Prince Hamlet's Age (Copenhagen, 1924; see especially pp. 34-6). Cf. also W. W. Greg, Aspects of Shakespeare (British Academy, 1933), p. I48. ${ }^{6}$ See p. 86 above. 
Wright had suggested that between the versions of the play represented respectively by $Q_{1}$ and $Q_{2}$ " no substantial change was made, and that the chief differences. . . are only such as might be expected between a bona fide, and a mala fide, transcription".' I would also place M. R. Ridley's theory in this category. Although he regards certain differences between the two Quartos as pointing to a measure of revision between them, he strongly emphasizes the closeness of the version of the play underlying QI and that found in full in $Q_{2} .^{2}$

These, then, are the various hypotheses in the field, and we must now set ourselves to discover which if any is the correct one.

I The Cambridge Shakespeare, vol. vIII (1866), p. x.

2 The Nerw Temple Shakespeare: Hamlet (1934), pp. viii-xi. 


\section{CHAPTER FOUR}

\section{BLANK VERSE PECULIAR TO QI}

There is in the first Quarto a certain amount of metrically regular blank verse which bears little or no phraseological relation to the passages which occur at the corresponding points in the authentic editions. This blank verse generally embodies much the same content as the other versions, but the wording and the style are quite distinct. This verse, peculiar to QI I, has been accounted for in different ways by upholders of different hypotheses of the Quarto as a whole. The critics who believe that the QI text represents a partial Shakespearian revision of the $\widetilde{U} r$-Hamlet regard the verse unique in that text as unrevised portions of the early play. Critics who consider QI entirely Shakespearian, but a Shakespearian first draft, suggest that the verse we are discussing is early work of Shakespeare's, for which he substituted new material in his later revision. Those who contend that the text of QI depends entirely on that given in $\mathrm{Q}_{2}$ or $\mathrm{F}_{\mathrm{I}}$, and that a hack-poet filled in gaps in the reporting by his own inventive powers, attribute these passages of verse to him.

The dangers of applying subjective literary criticism to textual problems is strikingly illustrated by the fact that different critics refer the same material to Kyd, to Shakespeare, and to an anonymous third-rate hack-writer. The judgement of Boas is that "the bulk of the blank verse in the three later Acts is, in my opinion, unmistakably pre-Shakespearian. The vocabulary and the rhythm are not those of the master-dramatist at any stage of his career, while in Kyd's works they may be frequently paralleled".

${ }^{x}$ Works of Kyd, p. xlix. 
On the other hand, Dowden declares: "For my own part repeated perusals have satisfied me that Shakespeare's hand can be discerned throughout the whole of the truncated and travestied play of 1603 . The Shakespearian irony of many passages is unlike anything we find in plays of I 588-9. With the exception of five lines beginning 'Look you now, here is your husband', I find nothing that looks pre-Shakespearian, and I see much that is entirely unlike the work of Kyd." I Furnivall too concludes that "no other hand than Shakespeare's is reported, or misreported, in the first Quarto of 1603 , and that his handiwork so treated is his first cast of his play". "2 The attribution to Kyd of the verse peculiar to $\mathrm{Q}_{\mathrm{I}}$ is impressively answered by Professor H. D. Gray and Miss Linda Van Norden, who compare in great detail the styles of $\mathrm{Kyd}$ and of the blank verse of QI and find them utterly different. ${ }^{3}$ It seems to me even more absurd that anyone could attribute it to Shakespeare.

Fortunately, however, it is unnecessary to rely on the stylistic criteria of judgement which have produced such diverse results. An analysis of some of the verse peculiar to the "bad" Quarto will show exactly how it was composed. Many passages consist simply of numerous stray fragments of text gathered together from various points scattered throughout the full Shakespearian versions, and even occasionally from other plays. These fragments are welded into presentably metrical, though generally dull and flat, blank verse. The person responsible has used his own powers of ingenuity and inventiveness in fitting the fragments together and in connecting them with short pieces of original matter.

I propose in the following pages to examine several passages of this kind of verse. The result of the examination

I Hamlet: Arden edition, pp. xviii-xix.

2 Griggs's facsimile of $Q_{1}$ Hamlet, introduction, p. viii.

3 Publications of the Modern Language Association of America, vol. XLII (r927), pp. 726-8. 
will be a refutation of the view that metrical blank verse found only in QI is unrevised material from the $U_{r}$-Hamlet or early Shakespearian work, and a vindication of the theory of Mommsen, Creizenach, H. D. Gray, and others, that a hack-poet of some sort was involved in the compilation of the QI text. ${ }^{\mathrm{I}}$

\section{I}

(Scene vi lines $\mathrm{I}-\mathrm{I} 8$ and scene viii)

The first eighteen lines of scene vi in QI correspond to II ii $1-39$ of the authentic text: the King and Queen welcome Rosencrantz and Guildenstern to the court and request them to attempt to discover the cause of Hamlet's strange conduct. Scene viii lines $\mathrm{I}-23$ correspond to III i I-28, where Rosencrantz and Guildenstern report their failure to get this information from Hamlet, and announce the performance of "The Murder of Gonzago" which he has arranged. The last seventeen lines of scene viii correspond to III i I 84-9I, where Polonius arranges for the Queen to summon Hamlet to her closet after the play. Both passages which we are about to consider are metrically. regular apart from a small block of text in scene viii (lines 24-3I) and two other lines in that scene (lines I and IO) which are short by a foot and a syllable respectively. Scene viii line 37 passes as metrical.

Let us take scene vi first. Lines $4-7$ provide an admirable starting point:

Therefore we doe desire, euen as you tender Our care to him, and our great loue to you, That you will labour but to wring from him The cause and ground of his distemperancie.

I Throughout this work the references to passages in $Q_{1}$ are by the scene and line numbers of the reprint in the old Cambridge Shakespeare, and the references to the received text are by the act, scene and line numbers of the edition in The Nerw Shakespeare (ed. Dover Wilson). 
Part of this is echoed later in QI, in scene xi lines I 55-7:

Well sonne Hamlet, we in care of you: but specially in tender preseruation of your health,

The which we price euen as our proper selfe,...

At the point corresponding to this latter passage the "good" texts read as follows:

Hamlet, this deed, for thine especial safety,

Which we do tender, as we dearly grieve

For that which thou hast done, must send thee hence....

(Iv iii 39-4I)

The verb "tender" here has formed in the reporter's mind an association-link with Henry $V$ II ii 56-9:

We'll yet enlarge that man,

Though Cambridge, Scroop, and Gray, in their dear care And tender preservation of our person

Would have him punished.

Thus "tender", a verb in Hamlet Iv iii 40, becomes an adjective in QI xi I 56, as in Henry $V$ II ii 58, and the alteration entails a borrowing (with modifications) from that play, namely, the words "in care of you" and "in tender preservation". The borrowing is indissolubly bound up with a fragment of the authentic Hamlet text; for the words "but specially", embedded in the borrowed material, are clearly derived from a vague recollection of "thine especial safety" (Iv iii 39). "Tender" having become an adjective, the verb "price" is substituted for it (QI xi I 57). Now in QI vi $4-5$ the verb "tender" is an anticipation of IV iii 40: and not only is that passage anticipated but also the confusion of it with the lines quoted from Henry $V$; this accounts for the words "our care to him" in QI vi 5. It is extraordinary that, anticipating IV iii 40 , the reporter should retain "tender" as a verb and yet also partially foreshadow the confusion of the later passage with Henry $V$, 
94 BLANK VERSE PECULIAR TO $Q$ I

which confusion caused him to use "tender" as an adjective in scene xi line 156 .

Line 6 of QI scene vi contains another interesting confusion. The King desires that Rosencrantz and Guildenstern "will labour but to wring from" Hamlet the cause of his distemperance. Almost certainly the reporter had at the back of his mind a passage in Act I scene ii of the full Shakespearian text. Laertes has begged the King's permission to return to France; the King asks if he has his father's consent:

King. Have you your father's leave? what says Polonius?

Pol. He hath, my lord, wrung from me my slow leave

By laboursome petition, and at last

Upon his will I sealed my hard consent.

I do beseech you give him leave to go.

This is derived from $Q_{2}$ : in $F_{1}$ we have only

King. Haue you your Fathers leaue? What sayes Pollonius?

Pol. He hath my Lord:

I do beseech you giue him leaue to go.

But the omission is probably accidental and not a playhouse cut $^{\mathrm{I}}$ for at the corresponding point the QI text attempts the fuller version:

King. Haue you your fathers leaue, Leartes?

Cor. He hath, my lord, wrung from me a forced graunt, And I beseech you grant your Highnesse leaue.

(ii $2 \mathrm{I}-3$ )

I believe that at vi 6 in QI the reporter was influenced by a vague recollection of the full form of this passage as found in $\mathrm{Q}_{2}$ : the juxtaposition of "wrung" and "laboursome" on the one hand and "labour" and "wring" on the other can hardly be coincidence.

I See Dover Wilson, The Manuscript of Shakespeare's "Hamlet", vol. I, pp. 22-23. 
QI vi 7 ("The cause and ground of his distemperancie" ") ${ }^{\mathrm{I}}$ seems to be the result of the association of three separate passages in the full play. The reporter is obviously indebted to III ii 338, where Rosencrantz asks Hamlet "Good my lord, what is your cause of distemper?" But probably he also had at the back of his mind II ii 54-5, where synonyms are used (though different from those in QI): the King tells the Queen Polonius's news:

He tells me, my dear Gertrude, he hath found

The head and source of all your son's distemper.

Lastly, the reporter uses the word "ground", anticipating the Gravediggers' scene and forgetting or ignoring the pun: again Hamlet's madness is being discussed:

Ham. How came he mad?

I Clo. Very strangely, they say.

Ham. How strangely?

I Clo. Faith, e'en with losing his wits.

Ham. Upon what ground?

I Clo. Why, here in Denmark:... (v i $15 \mathrm{I}-6)$

Here, then, we have four lines towards the beginning of QI scene vi, consisting of various fragments gathered together from widely separated source-passages and woven into a complex metrical whole.

One or two phrases from In ii I-39 have stuck in the reporter's memory. Consider QI vi 9-I 5:

Ros. My Lord, whatsoeuer lies within our power Your maiestie may more commaund in wordes

Then vse perswasions to your liege men, bound

By loue, by duetie, and obedience.

Guil. What we may doe for both your Maiesties

To know the griefe troubles the Prince your sonne,

We will indeuour all the best we may,... ture".

I Cf. also Qr ix 189 "the ground and cause of your distempera- 
Clearly the reporter remembered, though not very distinctly, II ii 26-9: Rosencrantz says

Both your majesties

Might by the sovereign power you have of us,

Put your dread pleasures more into command

Than to entreaty.

The word "power" was present in the reporter's mind, but detached from its immediate setting; also present in his mind was a passage a few lines earlier (II ii 1 7-I 8) where the King asks Hamlet's two friends to gather

Whether aught to us unknown afflicts. him thus,

That opened lies within our remedy.

Thus, from broken phrases recollected without their setting, the reporter produced "whatsoeuer lies within our power". He produced the words "may more commaund" from the authentic texts' "might...put... more into command"; and he remembered the phrase "both your majesties" which, however, he misplaced. But even here in vi $9-15$ his text is influenced by reminiscences of passages in other scenes. "We will indeuour all the best we may" suggests a reminiscence of Hamlet's words to his mother in I ii I 20- "I shall in all my best obey you"; and the phrase "by duetie and obedience" recalls Polonius's words in II ii 107-8 about his daughter

Who in her duty and obedience, mark,

Hath given me this.

In QI vi I4 Guildenstern talks of the "griefe" which "troubles" Hamlet: "griefe" might be a reminiscence from any of several lines in the full play, for example III i 180 , where Polonius speaks of "the origin and commencement of his grief" and, a few lines later, says

Let his queen-mother all alone entreat him

To show his grief. 
"Troubles" corresponds to "afflicts" in the "good" texts (Ir ii 17), and may have its source in a dim recollection of Hamlet's reaction to the narrative of Horatio, Marcellus and Barnardo in I ii 224: "Indeed, indeed, sirs, but this troubles me." The reporter repeats this verb later, in scene vii line 2, where after witnessing the meeting between Hamlet and Ofelia the King says

Loue? No, no, that's not the cause,

Some deeper thing it is that troubles him.

In the first three lines of scene vi the reporter has apparently modelled his construction upon that of a fragment of the genuine text, while maintaining independence for the most part as regards phrasing. The scene begins thus:

Right noble friends, that our deere cosin Hamlet

Hath lost the very heart of all his sence,

It is most right, and we most sory for him:

Much later in QI the reporter virtually repeats himself: the King says to the incensed Laertes:

that your father is murdred,
(xiii $57-8$ ) Now we have already noticed one case where the reporter neglects a quibble; and it is not impossible that when he wrote the first three lines of scene vi he was influenced by the sense and construction of II ii $97-8$ of the authentic text, though not by the actual words: there Polonius says

That he is mad 'tis true, 'tis true 'tis pity,

And pity 'tis 'tis true.

It is interesting to observe further that in the passage directly corresponding to QI scene viii Polonius uses the words "'Tis most true" in another connection (III i 2I): we shall find that the reporter confuses scenes vi and viii at certain points in the latter, and this may be a similar case in the former. Notice further that in the first line of 
scene vi the King addresses Rosencrantz and Guildenstern as "Right noble friends"; in the "good" texts at II ii 58 he greets Cornelius and Valtemand with the words "Welcome, my good friends". And "our deere cosin Hamlet" in QI vi I may be explained as a reminiscence of I ii 64 ("But now my cousin Hamlet, and my son") or IIr ii 90 ("How fares our cousin Hamlet?"): compare also $I$ ii I I 7 and $v$ ii 257.

Finally, lines $\mathrm{I}_{7-1} 8$ of QI scene vi reproduce II ii $33-4$ with an inversion and with the corruption of the proper names which appears throughout the text:

King. Thankes Guilderstone, and gentle Rossencraft, 2ue. Thankes Rossencraft, and gentle Guilderstone.

$$
\text { (QI vi } \text { I }^{-1} \text { 8) }
$$

King. Thanks Rosencrantz, and gentle Guildenstern. Queen. Thanks Guildenstern, and gentle Rosencrantz.

(Received text, II ii 33-4)

QI scene vi lines I-I 8 and scene viii are closely connected. In the first place certain phrases used in scene vi, for which sources have been suggested, are repeated, or at least clearly echoed, in scene viii. Thus with vi I 5 ("We will indeuour all the best we may") compare viii 5 ("we haue done all the best we could"): in both cases the speaker is Guildenstern. In vi $6-7$ we have

\section{to wring from him}

The cause and ground of his distemperancie. and in viii 6

To wring from him the cause of all his griefe. "Griefe" occurs in vi 14 , and in viii $26-7$ we find the very ground Of his distemperance.

In vi 8 the King says "the king of Denmarke shal be thankefull", and in viii r6 "we vnto your selues will still be thankefull". Further, "the king of Denmarke" is 
balanced in viii I 8 by "the Queene of Denmarke". The person who wrote this blank verse peculiar to $Q$ I had a habit of repeating himself.

In the second place, there are two points in scene viii where the reporter had in mind passages in that part of the authentic text which corresponds to scene vi lines $\mathrm{I}-\mathrm{I} 8$. In viii $3-4$ the King says to Rosencrantz and Guildenstern:

You being so neere in loue, euen from his youth, Me thinkes should gaine more than a stranger should.

This corresponds to $\mathrm{II}$ ii $\mathrm{r} 0 \mathrm{ff}$.:

I entreat you both, That being of so young days brought up with him, And sith so neighboured to his youth and haviour, That you vouchsafe your rest here in our court

\section{...to gather}

So much as from occasion you may glean....

And in QI viii I 8-I9 the Queen says to them:

Thankes gentlemen, and what the Queene of Denmarke

May pleasure you, be sure you shall not want.

In the passage in the authentic texts corresponding to QI viii $\mathrm{I}-23$ there is no mention of reward for the two young men's spying activity; but in In ii 25-6 the Queen tells them that

Your visitation shall receive such thanks

As fits a king's remembrance.

In scene viii as in scene vi we find gathered together reminiscences of various passages of the genuine text. Take the first two lines of scene viii:

Lordes, ${ }^{\mathrm{I}}$ can you by no meanes finde

The cause of our sonne Hamlets lunacie?

be

I Compare the similar opening of Qr scene ii: "Lordes, we here is haue writ to Fortenbrasse...." 
The reporter has remembered the phrase "by no means" from the corresponding scene in the authentic text (III i 5-6), where Rosencrantz says:

He does confess he feels himself distracted

But from what cause a' will by no means speak.

But the phrase is recollected in isolation and fitted into a new context. Again, in $\mathrm{III}_{\mathrm{i}} 4$ the King speaks of Hamlet's "turbulent and dangerous lunacy"; but the reporter remembered another passage containing this word "lunacy", namely, In ii 48-9 where Polonius says to the King:

I have found

The very cause of Hamlet's lunacy.

Recollecting words from this passage, and the construction of III i I-2:

And can you by no drift of conference

Get from him why....

the reporter has produced the question

can you by no meanes finde

The cause of our sonne Hamlets lunacie?

We have a further indication that II ii 48-9 was in the reporter's mind in the fact that at viii $26-7$ Q I has the phrase "the very ground/Of his distemperance": here there is a thorough confusion between "the very cause of Hamlet's lunacy" and QI vi 7 ("The cause and ground of his distemperancie") - a line which has already been annotated. The complexity of the composition of this blank verse in QI is becoming more and more apparent; not only are elements brought together from scattered passages in the full text, but passages in that text are split up and their elements redistributed. 
BLANK VERSE PECULIAR TO QI IOI

Now let us analyse $Q$ I viii i 7-I9:

Both. In all wee can, be sure you shall commaund.

2ueene. Thankes gentlemen, and what the Queene of Denmarke May pleasure you, be sure you shall not want.

"In all wee can" echoes QI vi i 5 (" all the best we may") and viii 5 ("all the best we could"), and the word "in" renders even more probable the suggested derivation of these phrases from Hamlet's "I shall in all my best obey you, madam" ( ii I 20). "Be sure you shall commaund" reminds us again of scene vi where Rosencrantz says:

whatsoeuer lies within our power

Your maiestie may more commaund in wordes

Then vse perswasions....

(QI vi 9-I I : derived from $Q_{2}$ II ii 26-9)

The Queen's reply in viii i 8-I9 instantly recalls Hamlet's assurance to Horatio and Marcellus after they have sworn not to reveal the Ghost's appearance (I v I 84-6; Q I iv 228-9). This reads in Qr :

And what so poore a man as Hamlet may,

To pleasure you, God willing shall not want,...

and in the "good" texts:

And what so poor a man as Hamlet is

May do t'express his love and friending to you

God willing shall not lack.

The use of the verbs "pleasure" and "want" prove that it was. the QI version of this passage that the reporter had in mind when he wrote viii $18-19$; but there is no reason to suppose that that version is not derived from the other.

Verbal contacts exist between QI viii I I-I2 and III i $20 \mathrm{ff}$. in the authentic text: compare QI

(Ross.) He hath giuen order for a play to night, At which he craues your highnesse company. 
and the full text

(Ros.) they have already order This night to play before him.

Pol. 'Tis most true, And he beseeched me to entreat your majesties To hear and see the matter.

A comparison of the King's answer in each version is illuminating. In the "good" texts (III i 24-5) he says

With all my heart, and it doth much content me To hear him so inclined.

QI reproduces the first four words, altering "my" to the royal "our", and then confuses this reply with that made by the King to Valtemand in II ii 80- "It likes us well"; thus QI viii I 3 reads "With all our heart, it likes vs very well"I. But the remainder of III i $24-5$ has also contributed to QI scene viii: the content of these lines is reproduced there in lines 22-3, where the Queen says

it ioyes me at the soule

$\mathrm{He}$ is inclin'd to any kinde of mirth. ${ }^{2}$

"Inclined" is derived from mI i 25; "any kinde of mirth" is indebted to a recollection of "a kind of joy" (III i I 8). "Mirth" itself is probably a reminiscence of II ii 299, where Hamlet says to Rosencrantz and Guildenstern "I have of late... lost all my mirth". But "a kind of joy" also underlies "it ioyes me at the soule" (QI viii 22).

Another passage full of reminiscences of various parts of the full play occurs towards the end of scene viii (lines $3 I-6)$. Corambis is the speaker:

I "It likes vs well" is repeated in viii 37 , "With all my heart" (spoken this time by the Queen) in viii 38 .

2 "Inclin'd to mirth" also occurs in viii 9. 
soone when the sports are done,

Madam, send you in haste to speake with him,

And I my selfe will stand behind the Arras,

There question you the cause of all his griefe,

And then in loue and nature vnto you, hee'le tell you all:

My Lord, how thinke you on't?

The corresponding passage in the "good" texts (III i I 84-8) runs as follows:

But if you hold it fit, after the play,

Let his queen-mother all alone entreat him

To show his grief, let her be round with him,

And I'll be placed (so please you) in the ear

Of all their conference.

The phrase "to show his grief" probably underlies the last line of QI scene viii, where Corambis expresses the hope that Hamlet's "griefe will be reueal'd to her".

Corambis's words "send you in haste to speake with him" anticipate Act III scene ii, where Rosencrantz and Guildenstern actually deliver the Queen's message to Hamlet. In III ii 31 2-3 Guildenstern says "The queen your mother, in most great affliction of spirit, hath sent me to you"; a little further on (line 332) Rosencrantz says: "She desires to speak with you in her closet ere you go to bed": later Polonius enters and delivers the same message: "My lord, the queen would speak with you, and presently" (III ii 376):

Corambis says that he will "stand behind the Arras" (QI viii 33).. The reporter doubtless remembered something of III iii 27-9, where Polonius says to the King:

My lord, he's going to his mother's closet-

Behind the arras I'll convey myself

To hear the process....

Compare also In ii $\mathrm{r}_{3} 3$ and IV i 9. 


\section{IO4 BLANK VERSE PECULIAR TO QI}

QI viii 34- "There question you the cause of all his griefe" - reminds us of the interview itself, where Hamlet says to his mother "you question with a wicked tongue" (III iv I2). "The cause of all his griefe", already used in the sixth line of this scene in $\mathrm{QI}$, is a conflation of "the origin and commencement of his grief" (III i I 80) and "what is your cause of distemper?" (III ii 338) or perhaps "the very cause of Hamlet's lunacy" (I ii 49).

Corambis says that Hamlet will be frank with his mother "in loue and nature" (QI viii 35). The word "nature", in this same sense, is used in the "good" texts, also in connection with Hamlet's interview with the Queen, in III ii 395-6, where Hamlet says

O heart, lose not thy nature.

soft, now to my mother-

The word is also used of Hamlet's filial obligations to his dead father in I $\mathrm{v} 8 \mathrm{I}$.

I suggest that the words "hee'le tell you all" provide us with a good instance of the reporter remembering a phrase quite apart from its original context. In III ii I 40 Hamlet exclaims "The players cannot keep counsel, they'll tell all": a line or two later we have "be not you ashamed to show, he'll not shame to tell you what it means". The "he" is the prologue-speaker-"this fellow". Now in QI, at the point corresponding to this, there is a good deal of confusion: but what concerns us here is scene ix line 89 , where Hamlet says "this fellow will tell you all". This is clearly a mixture of elements from the authentic text; and in all probability "hee'le tell you all" in QI viii 35 was written with this in mind but divorced from its context. Coincidence seems hardly credible.

Corambis's concluding words in the speech we have been considering-"My Lord, how thinke you on't?"doubtless contain the reporter's recollection of III i I 78 , where the King, asking Polonius's opinion of the plan to 

send Hamlet to England, says "What think you on't?" Again the reporter remembers the words but not their context; for there is no mention in QI scene viii of the King's own plan.

At one point in QI scene viii the metre breaks down seriously, and the text becomes incoherent (lines 27-9). The lines conclude a speech of Corambis which begins with the words "Madame, I pray be ruled by me", where the reporter was probably influenced by either of two passages in the authentic text. In I iv 8I Horatio, trying to dissuade Hamlet from following the Ghost, cries "Be ruled, you shall not go"; and in IV vii $5^{8}$ the King asks Laertes "Will you be ruled by me?" A few lines later (Iv vii 67), at the beginning of a passage present in $Q_{2}$ but omitted from F I, Laertes says "My lord, I will be ruled".

The lines in which the QI text deteriorates so strikingly run

therefore

I holde it meete, if so it please you,

Else they shall not meete, and thus it is.

It is clear from the lines which follow this that Corambis is intent on his plan for the interview between Hamlet and the Queen, to be observed by him himself. It is therefore all the more likely that the reporter had a hazy memory of IIr iii 3 I:

'Tis meet that some more audience than a mother,

Since nature makes them partial, should o'erhear

The speech of vantage; ...

And probably the sound of "meet" brought to his mind another passage also: he was writing about one of the tests to which Hamlet is subjected-the interview with the Queen: the words "else they shall not meete" mean, as is seen from the sequel, that Hamlet and the Queen should not hold converse except under observation. Quite possibly the reporter has remembered just one word which is used 


\section{IO6 BLANK VERSE PECULIAR TO $Q_{I}$}

in the authentic texts in connection with another test which Hamlet undergoes in similar circumstances-the interview with Ophelia. In II ii 213 Polonius says, aside, "I will leave him, and suddenly contrive the means of meeting between him and my daughter". Having remembered "meet" in one sense from in iii $3 I$, the reporter immediately remembers the same word in another sense from Ir ii 213 .

It is by now quite obvious that in the passages with which we have been concerned the QI text is a patchwork of words and phrases (often quite commonplace) remembered from widely separated sources in the full play. The bulk of scene viii is among those passages which Furnivall lists as probable portions of Shakespeare's first draft; ${ }^{\mathrm{I}}$ but there is clearly no question of that here. Nor is there any question of the survival at these points in Q 1 of verse from the old Hamlet, unrevised by Shakespeare. As far as vi $I-18$ and viii are concerned, nothing stands behind $Q_{I}$ except the full play as found in $Q_{2}$ and $F_{I}$; and these passages owe their existence to the memory and the mediocre poetic skill of a reporter-versifier, whose hand can be detected in other passages throughout QI. One of his most marked characteristics is a tendency to repeat phrases. We have already noted the repetition in scene viii of material from scene vi. There are also several repetitions within scene viii itself, which I give before passing to other passages of his making: "by no meanes" (lines I and 7), "the cause of all his griefe" ${ }_{2}$ (lines 6 and 34), "inclin'd to mirth" 3 (lines 9 and 23), "with all our (my) heart" (lines I 3 and 38), "it likes vs (very) well" (lines I 3 and 37), "be sure" (lines I 7 and I9), "my selfe" (lines 33 and 39), "send" (lines 32 and 38).

\footnotetext{
I Griggs's facsimile of $Q_{1}$, p. vii.

2 "griefe" also occurs in line 40.

3 " mirth" also occurs in line 14.
} 
THE KING'S SOLILOQUY IN THE

PRAYER-SCENE

\section{(QI scene $x$ lines $\mathrm{I}-\mathrm{I} 3$ )}

One of the most notable features of the QI version of this speech is that the King reproaches himself not only for the murder of his brother, but also for "the adulterous fault I haue committed"; in the "good" texts it is only "a brother's murder" which concerns him. Now in the Closet-scene Hamlet accuses his mother of participation in the very crimes of which Claudius here accuses himself in Q1. A transition is quickly made from the killing of a king to the marrying with his brother, and Hamlet proceeds to make the adultery and incest the main subject of his denunciation. If a reporter, relying on memory alone, confused the two scenes, he might be led to make in the Prayer-scene the same transition as is later made in the Closet-scene.

Indications that such a confusion did in fact take place are furnished by certain verbal links between the two scenes in QI. In his self-reproaches in the "good" texts Claudius refers to his "offence", his "guilt", his "fault": at one point in the QI version, however, he says

When I looke vp to heauen, I see my trespasse.

This word "trespasse" does not occur in the soliloquy of $\mathrm{Q}_{2}$ and $\mathrm{F}_{\mathrm{I}}$; but in the Closet-scene as found in these texts Hamlet says to the Queen:

Mother, for love of grace, Lay not that flattering unction to your soul, That not your trespass but my madness speaks.

and, a line or two later,

(III iv I44-6)

Confess yourself to heaven. 
Her "trespass" was shared by Claudius, and I have no doubt that this is the source of the word in the QI soliloquy. It is made even surer by the King's final "Aske grace of heauen..." (QI x I 3), which is a conflation of "for love of grace" and "Confess yourself to heaven".

Consider now the words

I but still to perseuer in a sinne,

It is an act....

(QI x IO-II)

This closely resembles a line in the Qr Closet-scene not found in either $\mathrm{Q}_{2}$ or $\mathrm{F}_{\mathrm{I}}$ :

Nay but still to persist and dwell in sinne.

(QI xi 5 I)

The source of these two lines in $\mathrm{QI}_{\mathrm{I}}$ is to be found away back in the first Act of the full play. In the Council-scene the King says to Hamlet:

\section{But to persever}

In obstinate condolement...

It shows a will most incorrect to heaven, . . .

(I ii $92 \mathrm{ff}$.)

From this passage are derived the King's words "I but still to perseuer in" (QI $\times 10)$; the idea is present in the authentic version of the soliloquy, in other phrasing, apart from "still" which the reporter has remembered:

I am still possessed

Of those effects for which I did the murder;

May one be pardoned and retain th'offence?

A few lines further on in the Council-scene the King says:

$$
\text { fie, 'tis a fault to heaven, }
$$

A fault against the dead, a fault to nature. 


\section{BLANK VERSE PECULIAR TO QI}

At the corresponding point in QI we have

It is a fault gainst heauen, fault gainst the dead,

A fault gainst nature,...

In the QI Prayer-scene the reporter's mind casts back to the words "It is a fault gainst heauen", words which are based on the authentic text (with a slight inaccuracy). But for "fault" he substitutes "act": QI X I I runs

It is an act gainst the vniuersall power.

Now the word "act", referring to the sinful association between Claudius and Gertrude, is used several times with striking effect in the full version of the Closet-scene: "What have I done?" the Queen asks; "Such an act..." is the reply, and then "this solidity and compound mass/Is thought-sick at the act"; and again she cries "Ay me, what act?" (III iv 39, 40, 5 I). Q I X I I , then, contains a combination of fragments from I ii IOI-2 and these lines in IIr iv. For the word "heaven" ( $\mathrm{r}$ ii I $\mathrm{I}$ I) the reporter-versifier substitutes "the vniuersall power". This phrase reminds one of "the Everlasting" in the authentic version of Hamlet's first soliloquy (I ii I 3 I): and when we turn to the QI version of that speech we find this word "vniuersall":

$\mathrm{O}$ that this too much grieu'd and sallied flesh

Would melt to nothing, or that the vniuersall

Globe of heauen would turne al to a Chaos!

(ii 55-7)

Compare the last line and a half of this with the corresponding passage in the genuine text:

Or that the Everlasting had not fixed

His canon 'gainst self-slaughter.

(r ii $\mathrm{I} 3 \mathrm{I}-2$ )

It would appear that, having managed an approximation to the first two lines of this soliloquy, the reporter's memory temporarily broke down and he had to use invention. The word "vniuersall" probably represents a desperate stab at 


\section{IO BLANK VERSE PECULIAR TO $Q$ I}

"Everlasting": and later the reporter turns back to "the Everlasting", this time in Shakespeare's sense, but uses his own word and substitutes "the vniuersall power". I

It may well be that the opening of Hamlet's first soliloquy (I ii I $29 \mathrm{ff}$.) was the reporter's model for the opening of his version of the King's soliloquy in the Prayer-scene: the basic structural elements "O that this... would" are present in both. Here are the King's first two lines:

O that this wet that falles vpon my face

Would wash the crime cleere from my conscience!

These lines correspond to, and were no doubt initially suggested by a vague recollection of, the following passage in the "good" texts:

What if this cursed hand

Were thicker than itself with brother's blood, Is there not rain enough in the sweet heavens

To wash it white as snow?

(III iii 43-6)

Thus QI x I-2 combines the construction of I ii 129 with an important word ("wash") from III iii 46. Furthermore, the mention of rain in III iii 45 seems to have suggested to the reporter that the King was praying out-ofdoors and that it was raining: in Q $\mathrm{I}_{\mathrm{X}} \mathrm{I}$ the $\mathrm{King}$ speaks of "this wet that falles vpon my face", and then proceeds to the idea of "this wet", that is the rain, ${ }^{2}$ washing away his guilt, just as in the authentic text. And there is more to be said: in QI x 2 the King desires that the rain "wash the crime cleere from my conscience". In the full play, at IFr i 49-50, he says, aside,

O'tis too true,

How smart a lash that speech doth give my conscience.

x Cf also "O heavenly powers, restore him!" (III i r44).

2 This seems a much more probable interpretation of "this wet" than the supposition which might be made that the King is referring to crocodile tears of repentance. 
It is quite easy to imagine a reporter confusing two separate passages where the same character speaks in similar conscience-stricken terms and juxtaposing words taken from each-in this case "wash" from the later passage, "my conscience" from the earlier. It seems, then, that QI x I-2 combines the following elements from the full play: the construction of $\mathrm{I}$ ii $\mathrm{I} 29$, the idea of falling rain from III iii 45, the word "wash " from III iii 46, and the words "my conscience" from III i 50."

We have already discovered that just as widely separated words and phrases in the "good" texts are fused together in the blank verse peculiar to the "bad" Quarto, so words in the same line in the former are sometimes separated and redistributed in the latter. The verb "wash" is taken from III iii 46 and introduced into QI x 2; the phrase "white as snow", also in III iii 46 , appears in QI x 9, where it is used in close conjunction with its opposite:

Why say thy sinnes were blacker then is ieat, Yet may contrition make them as white as snowe:

(QI x 8-9)

Now towards the end of his soliloquy in the genuine version the King exclaims "O bosom black as death!", (III iii 67). Thus the contrast between "white as snow" and "black as death" exists in the genuine version of the speech, though the references are not to the same things. The reporter has remembered this contrast, and associated its two elements in close connection with each other. But he has altered "black as death" to "blacker then ....ieat", thus employing a conventional antithesis to "white as snow". The basis of the antithesis, however, lies in an imperfect recollection of two parts of the full Shakespearian soliloquy. As for the line "yet may contrition make

I With "the crime" (QI x 2), cf. I v r2, III iii 8I. 
them as white as snowe", it telescopes two passages of the full version; the first, already quoted, runs:

Is there not rain enough in the sweet heavens

To wash it white as snow?

(III iii 45-6)

and the second:

Try what repentance can-what can it not?

(Ibid. 65)

One or two other passages in this first Quarto soliloquy are grounded on reminiscences of passages of the Shakespearian text. "Most wretched man" (QI x 12) is obviously derived from an imperfect recollection of "O wretched state" (III iii 67). The phrase "When I looke vp to heauen" ( $\mathrm{Q}$ × x 3 ) echoes the corresponding words "then I'll look up" in III iii 50. And "stoope, bend thee to thy prayer" (QI x I 2) was doubtless suggested by a vague memory of "Bow stubborn knees" in min iii 70. "The murder of a brother and a king" is possibly a conflation of "A brother's murder" in III iii 38 and the phrase "as kill a king" in III iv 29-30.

One line in the QI soliloquy seems to be an appropriation from another play. There is nothing in the authentic version of the speech which directly corresponds to QI x 7:

O these are sinnes that are vnpardonable.

But there is a very close parallel in 3 Henry $V I$, $\mathrm{I}$ iv 106 :

O 'tis a fault too too unpardonable!

In QI x 6 the King mentions his "adulterous fault", and this is probably the verbal link with the line in 3 Henry VI, which the reporter immediately proceeds to quote inaccurately.

The composition of this soliloquy in the "bad" Quarto appears to be similar to that of the passages we examined in 
the preceding section: a reporter who was capable of writing metrical verse has bound together various fragments of text from the full Shakespearian Hamlet, and supplemented these with his own inventive powers. J. M. Robertson argued that the speech was a portion of the old play: he says of it that it "is not a first draft by Shakespeare, any more than it is a misreport of the soliloquy of the second Quarto: it is pre-Shakespearean." I He regards this speech, among other passages in Q $\mathrm{r}$, as "quite in the manner of The Spanish Tragedy and Arden of Feversham". From our examination of the soliloquy we can say with certainty that it is non-Shakespearian: and we posit ex hypothesi that it was concocted after the full text of $\mathrm{Q}_{2}$ was in existence. It cannot be denied; however, that there are places, here and elsewhere in $Q_{1}$, where the reporter-versifier, relying according to our theory upon his invention, employs a diction which has a pre-Shakespearian ring. I suggest, however, that this means no more than that he was familiar with pre-Shakespearian plays and that he himself founded his stereotyped out-of-date style upon them.

\section{III}

\section{(QI Scene iii lines 65-70)}

At the end of the scene which corresponds to I iii Corambis delivers a speech which appears thus in $\mathrm{Q} I$ :

Ofelia, receiue none of his letters, "For louers lines are snares to intrap the heart;

"Refuse his tokens, both of them are keyes

To vnlocke Chastitie vnto Desire:

Come in Ofelia, such men often proue,

"Great in their wordes, but little in their loue.

I The Problem of "Hamlet", p. 37 .

$\mathrm{DB} Q$ 
Furnivall considered that this passage "may well be Shakespeare's" I - part of his first draft which was replaced in the final revision by other material. Both this view, and the theory that the passage is unrevised matter from the old Hamlet, must in my belief yield to the hypothesis that it is the work of the reporter-versifier whose activities we have been studying.

Corambis begins with a vocative "Ofelia" which corresponds to that in the authentic texts at I iii 126 ; both cases precede a parental negative command. He proceeds with the words "receiue none of his letters", along with which consider also the words "Refuse his tokens". Both phrases contain elements extracted from two different lines in the full play-II ii I44, where Polonius tells the King and Queen that he had instructed Ophelia to "receive no tokens" from Hamlet, and II i I 06, where Ophelia says to her father "I did repel his letters". These two lines have been thoroughly confused by the reporter, who has in one case taken the words "receiue none of" from II ii I 44 ("receive no") and "his letters" from II i 106, and in the other case the word "tokens" from II ii I 44 and "his" from In i 106, where in addition the word "repel" probably underlies the QI "refuse". It is much more probable that a reporter should separate common words juxtaposed by Shakespeare, than that Shakespeare should carefully collect and juxtapose common words sometimes widely separated in his "source" or "first sketch".

Corambis observes sententiously that "louers lines are .snares to intrap the heart". Here the reporter is indebted to the final Shakespearian play for an image-the image behind Polonius's reference to Hamlet's vows as "springes to catch woodcocks" (I iii I I 5); he has embodied this image in words of his own.

I Griggs's facsimile of Qr, p. vii. 
BLANK VERSE PECULIAR TO QI II

Hamlet's letters and tokens are, according to Corambis,

To vnlocke Chastitie vnto Desire.

Here the reporter was vaguely conscious of I iii $3 \mathrm{I}-2$, where Laertes talks of the dishonour Ophelia may sustain if she lose her heart

or your chaste treasure open

To his unmastered importunity.

And the reporter's phrasing was affected by a recollection, out of context, of the words "locked" and "key" in I iii 85-6. These two words aptly coincide with the image behind $\mathrm{I}$ iii $3 \mathrm{I}-2$, and our versemongering reporter has made quite good use of his materials.

Finally, in the last two lines of the passage we are discussing, there is a manifest borrowing from Twelfth Night, where, at II iv I I9-2 I, Viola says

We men may say more, swear more: but indeed

Our shows are more than will; for still we prove

Much in our vows, but little in our love.

Now in the authentic text of Hamlet the hero's "vows" of love to Ophelia are mentioned in I iii I I 4 and I27. As $\mathrm{Mr}$ Crompton Rhodes has pointed out, the mention of "vows" here has awakened the reporter's memory of Viola's words. ${ }^{\text {I }}$

We find, then, that this passage also consists of a tissue of reminiscences of various lines in the full play, eked out by an appropriation from Twelfth Night and by a certain amount of invention on the part of the reporter. It is not a fragment of Shakespeare's first draft, nor of the old Hamlet. Nor can it have stood in any authentic manuscript of the play at any stage in its text-history. It is pirate-work pure and simple. Professor Dover Wilson has

I Shakespeare's First Folio, p. 80. 


\section{II6 BLANK VERSE PECULIAR TO $Q$ I}

argued that the inverted commas here and earlier in the same scene in the "bad" Quarto, paralleled in other passages in the same scene in the second Quarto, suggest "the presence of an original manuscript at the back of $Q_{I}$ ". ${ }^{I}$ "Is it conceivable", he asks, "that any actor, reporter or publisher's hireling would put part of his material into inverted commas?... Shakespeare, like other dramatists of the age, occasionally marked out his 'sententious' passages by placing inverted commas at the beginning of the line; and the appearance of this device in $Q_{1}$ is conclusive indication of a dramatist's hand, whether Shakespeare's or another's." I must, on the contrary, suppose that the reporter-versifier was acquainted with this use of inverted commas and was himself responsible for it here. ${ }^{2}$

\section{IV}

\section{(QI Scene xi lines II I-I 3I)}

This passage corresponds to IV $\mathrm{i}-32$ in the authentic versions, the text of which it does not, however, follow. The nature of the construction of the QI text is similar to that of the other passages we have examined.

The King's first two words-"Now Gertred"correspond to his exclamation "What, Gertrude?" in IV i 6. In QI he proceeds with "what sayes our sonne", which corresponds to "Where is your son?" in IV i 3 . His next question in the QI text- "how doe you finde him?" - combines elements from IV i 6-"how does Hamlet?" -and III i $188-9$ :

\section{If she find him not, \\ To England send him.}

I The Library, 3rd series, vol. Ix, r9 8 , p. I63.

2 It is curious that in $Q_{1}$ iii 65-70 inverted commas appear before lines $66-7,70$ and not before lines $68-9$ where they would be equally appropriate. Dr Greg comments: "One cannot help suspecting that the passage originally read 'Refuse his tokens: such men often 
To the first words of the Queen's reply - "Alas my lord" - correspond the words "Ah, mine own lord" in Iv i 5 ; and her description of Hamlet as being "as raging as the sea" is derived from the picture drawn in IV i $7-8$.

Then the Queen declares that when Hamlet came to her closet she "first bespake him faire". The reporter probably based this phrase on his recollection of IV i 36 , where the King orders Rosencrantz and Guildenstern to seek Hamlet out and "speak fair" to him. ${ }^{\mathrm{T}}$

In Q I xi I I 5-6 Gertrude proceeds with her narrative:

But then he throwes and tosses me about, As one forgetting that I was his mother.

The best explanation of the first of these lines is that in it the reporter "puts into words what he has merely seen as dumb action on the stage". ${ }^{2}$ This gains in plausibility by the extreme likelihood that for the immediately following line the reporter is indebted to III iv $14 \mathrm{ff}$., where the Queen, disturbed by Hamlet's words and presumably also by his violent behaviour on entering her closet, says "Have you forgot me?"; and he answers

No by the rood not so,

You are the queen, your husband's brother's wife, And would it were not so, you are my mother.

\section{The Queen continues (Q I xi I I 7-20):}

At last I call'd for help: and as I cried, Corambis

Call'd, which Hamlet no sooner heard, but whips me

Out his rapier, and cries, a Rat, a Rat, and in his rage

The good olde man he killes.

proue,...' and that 'both... Ofelia' is an insertion." The subject of insertions is treated in Chapter vI. If this passage does contain an addition, it may quite well have been made by the reporter-versifier himself, revising and enlarging his own work: for the method of composition is the same throughout. See the Postscript to Chapter vI.

$x$ "Bespeak" itself occurs in the authentic text at II ii 140 .

${ }^{2}$ E. K. Chambers, William Shakespeare, vol. I, p. ${ }_{4} \mathrm{I} 6$. 
Line I 7 (continuing to the first words of line I I 8) was probably manufactured by the reporter from his memory of what had happened at the interview which is being described: at III iv 22-3 in the full text the Queen cries "Help, help, ho!" and Polonius, behind the arras, echoes her: "What, ho! help, help, help!" The construction of the phrase "which Hamlet no sooner heard, but..." is probably modelled on that of IV i 29-30, where the King says

The sun no sooner shall the mountains touch, But we will ship him hence,...

The word "heard" in line I 8 corresponds to "hearing" in the "good" texts at IV i 9. Lines I I 8-20 ("whips... killes") follows IV i I O-I 2 very closely: but for the phrase "in this brainish apprehension" (IV i I I) the reporter substitutes "in his rage", which he remembers, quite out of context, from mi iii 89 , where the same words are applied in a different sense to a different character.

The Queen having finished her story, the King speaks (QI xi I 2I-2):

Why this his madnesse will vndoe our state.

Lordes goe to him, inquire the body out.

When he wrote the first of these lines the reporter doubtless had in mind the purport of the first speech in III iii of the full play: and in addition to the underlying thought he makes two verbal borrowings:

King. I like him not, nor stands it safe with us To let his madness range...

The terms of our estate may not endure

Hazard so near us.... (III iii $\mathrm{I}-2,5-6$ )

For xi I 22 the reporter takes elements from IV i 36 and rearranges them: 
Go, seek him out, speak fair, and bring the body Into the chapel.

(Iv i $36-7)^{1}$

He had already used the words "speak fair", with modification, in xi I 14. Again it must be emphasized that it is far more probable that a reporter should separate and redistribute original Shakespearian words and phrases than that Shakespeare should gather together various commonplace words scattered about an earlier version.

In QI xi 124 the King continues with the remark "Gertred, your sonne shall presently to England". Here the reporter has remembered III i 72 in the "good" texts, where the King says "he shall with speed to England"." "Presently" corresponds to "with speed", but we may note in passing that "presently" itself occurs in the full play, in the same sense as here, in five passagesII ii I 70, 595; III ii 46,377; v ii $39 \mathrm{I}$ : and the adjective "present", meaning "immediate", occurs in IV iii 64 . The King's use of the pointed words "your sonne" agrees with that in four separate passages in the full play where Claudius, embarrassed by Hamlet's behaviour, subtly dissociates himself from responsibility for the hero: the relevant lines are II ii 55, IV i 3, IV v 79, v i 290 . This contrasts with I ii 64 , I I 7 , and v ii 285 where the King, anxious to appear to be friendly to Hamlet, stresses his assumed parenthood. That "your sonne" in QI xi I 24 has point may well be fortuitous; but in all probability the reporter remembered the words from the full text, whether he appreciated the point or not.

In QI xi I25 the King goes on: "His shipping is already furnished." There may be a debt here to IV i 30 , where the same speaker says "we will ship him hence".

I Cf. also IV iii I: "I have sent to seek him, and to find the body", where the last four words are closer to Qr's "inquire the body out".

${ }^{2}$ Cf. also III iii 4 and III iv 200. 
We have already noted that the construction of the line immediately preceding this in the "good" texts has been borrowed in Q1 xi I 8 ("no sooner... but...").

We now come to a most interesting line. The King states that he has sent by Rosencrantz and Guildenstern "Our letters to our deare brother of England" (QI xi I 27). The "letters" are mentioned in the full play in Iv iii 63 , and, in $\mathrm{Q}_{2}$ only, $\mathrm{II}$ iv 202. The really interesting phrase is "our deare brother of England", which is a combination of two separate phrases, one in the authentic Hamlet, the other in Henry $V$. In Hamlet I ii I and I9, Claudius refers to the dead King as "our dear brother"; in Henry $V$, II iv 75 and I I 5, the French King speaks of the English King, according to the Folio, as "our brother of England": and further in Henry $V$, $v$ ii IO, the French King addresses the English King as "brother England", and two lines later the French Queen echoes his words. ${ }^{2}$ In the line which we are annotating, QI Hamlet combines "our dear brother" and "our brother of England". In the first case the speaker is the same; in the second a foreign King is speaking of the English King just as here in $\mathrm{Q}_{\mathrm{I}}$.

Finally, in QI xi I 29-3I the reporter is indebted to the authentic text for the initial words "Happly the" and the word "Country" (see III i I 74). Failing to remember more, he embeds these words in lines substantially his own, lines intended to approximate to the purport of the corresponding passage in Shakespeare.

I In both cases the "bad" Quarto reads "our brother England", a reading adopted by Pope.

"In V ii $\mathrm{I}_{2} \mathrm{~F}_{1}$ has "brother Ireland", an error corrected in $\mathrm{F}_{2}$. 


\section{(QI Scene xvii)}

This short scene occurs immediately after Hamlet's violent quarrel in the graveyard. It corresponds in position to $\mathrm{v}$ i 288-93 in the authentic text, but the dialogue it contains is peculiar to $Q_{1}$, where the text runs as follows:

2ueene. Alas, it is his madnes makes him thus, I And not his heart, Leartes.

King. My lord, t'is so: but wee'le no longer trifle, This very day shall Hamlet drinke his last, For presently we meane to send to him,

Therefore Leartes be in readynes.

Lear. My lord, till then my soule will not bee quiet.

King. Come Gertred, wee'l haue Leartes, and our sonne, Made friends and Louers, as befittes them both, Euen as they tender vs, and loue their countrie. Io

2ueene. God grant they may. exeunt omnes.

In the first line the reporter has remembered the words "madness" and "thus" which occur very close together in v i 278-9:

This is mere madness, And thus awhile the fit will work on him.

But he has recollected them in isolation, and has worked them into a line the purport of which (with the next fragmentary line) is conditioned by his memory of $\mathrm{v}$ ii 232-5:

If Hamlet from himself be ta'en away, And when he's not himself does wrong Laertes,

Then Hamlet does it not, Hamlet denies it.

Who does it then? his madness.

The composition of line 3 is similar: the reporter remembers one or two words in isolation and works them into a line 
of his own. Probably the King's remark " $t$ 'is so" depends on a vague recollection of the same character's more prolix speech in IV vii $56-7$, where he is also addressing Laertes:

If it be so, Laertes, -

As how should it be so? how otherwise?

And he also remembered, quite out of context, the words "no longer" in vi 261 , and the first word of vi 289 , which reads

We'll put the matter to the present push,

and which exactly corresponds in implication to the $Q_{I}$ line. The word "present" probably underlies "presently" in QI xvii 5.

In xvii 5 the King says "we meane to send to him". This might be an anticipation of $\mathrm{v}$ ii 197, where a Lord bearing a message to Hamlet from the King says: "He sends to know if your pleasure hold to play with Laertes." This occurs in a passage omitted by the Folio; but it must be remembered that in scene xii line 3 QI has an unmistakable trace of the influence of a line in a passage absent from the Folio. ${ }^{2}$ Alternatively, however, the reporter may

I For the occurrences of "presently" itself in the "good" texts see p. Irg.

${ }^{2}$ QI xii 3 contains the words "Fortenbrasse nephew to old Norway", which correspond in position to the simple "Fortinbras" in the "good" texts (IV iv 2), but which anticipate IV iv r4: "The nephew to old Norway, Fortinbras"- a line omitted by Fr, in which text the whole of IV iv 9-66 is wanting. Interestingly enough, there is a possible trace of this same passage in Der Bestrafte Brudermord, where, at II ix $30 \mathrm{ff}$., Hamlet, summoning up his resolution, declares that "von dieser Stunde an will ich darnach treten, wo ich den König allein finde, ihm das Leben zu nehmen". This parallels IV iv 65-6 in $Q_{2}$ : "O, from this time forth,/My thoughts be bloody, or be nothing worth", which ends the long passage omitted by FI. Not only is there the definite verbal parallel: the import of the lines in $Q_{2}$ and the German text is similar. 
have had in mind either III i 29 or IV iii $\mathrm{I}$, in both of which the King states that he has "sent" for Hamlet.

In QI xvii 7 Laertes says "till then my soule will not bee quiet". Just as in line I the reporter remembers the commonplace words "madness" and "thus" from v i $278-9$, and just as in line 3 he remembers the equally commonplace "no longer" and "we'll" from v i 26 I and 289 , so here he remembers the words "quiet" and "till then" from $v$ i 292-3:

An hour of quiet shortly shall we see,

Till then, in patience our proceeding be.

The words which he recollects from this passage carry his mind back to I ii $256-7$ in the full play, from which he derives the words "my soul":

I doubt some foul play, would the night were come, Till then sit still my soul,...

Thus the composition of $\mathrm{Q}$ I xvii 7 provides a beautiful example of the workings of the reporter-versifier's mind: he gathers up three common words from $v$ i 292-3, forgetting their context; two of these words occur also in a passage away back in the first Act of the full play, so that his mind swings back and collects two words from there (I ii 257); then, out of these materials, he constructs a metrical line of his own.

In QI xvii 8 the King begins "Come Gertred, wee'l haue Leartes, and our sonne, ....". Just as in line 3 the reporter remembered the first word of $\mathrm{v}$ i $28 \mathrm{~g}$ and fitted it into a line of his own, and just as in xi 129 he remembered the first word of $\mathrm{II}$ i I 74 and then diverged from the authentic text a good deal, so here he has remembered the beginning (and that only) of Iv i $3^{8}$ in the authentic text, where the $\mathrm{King}$ says

Come, Gertrude, we'll call up our wisest friends, 
and fitted it into an entirely new context. Then he proceeds with a reminiscence of The Spanish Tragedy. ${ }^{\mathrm{I}}$ Compare the King's words in QI :

wee'l haue Leartes, and our sonne,

Made friends and Louers, as befittes them both,

with those of the Duke of Castile, addressed to Lorenzo and Hieronimo in Spanish Tragedy, III xiv 1 54-5:

But here, before Prince Balthazar and me,

Embrace each other, and be perfect friends.

"In both cases", says Boas, "the scene of feigned reconciliation is the prelude to the final catastrophe." The confusion with this scene in The Spanish Tragedy is further illustrated by the QI Hamlet reporter's appropriation in xvi I 64 of the phrase "I neuer gave you cause", from Spanish Tragedy, III xiv I 48.

Two further points remain in the analysis of QI scene xvii. The King's use of the verb "tender" in line 10 is probably based on that in IV iii 40 of the authentic text. And the concluding words of the scene, the Queen's fervent exclamation "God grant they may", probably owes its existence to the reporter-versifier's dim recollection of III i 42: the Queen expresses the hope that Ophelia will succeed in restoring Hamlet's sanity, when the meeting arranged between them takes place; she hopes that Ophelia's virtues

Will bring him to his wonted way again,

To both your honours.

And Ophelia replies "Madam, I wish it may". In both cases a wish is expressed for the success of a plan ostensibly calculated by the King to benefit Hamlet but really conceived in hostility towards him.

${ }^{1}$ See F. S. Boas, Works of Kyd, p. li. 


\section{BLANK VERSE PECULIAR TO QI I25}

We find, then, that the hand of our reporter-versifier is discernible throughout QI scene xvii, by virtue of his habit of patching together scattered fragments of the genuine text and even of another play. And in this scene as elsewhere we find in him a tendency to remember small unimportant words in the full play and incorporate them in different contexts:

\section{VI \\ (QI Scene xi lines 86-103)}

After the Queen has denied being able to see or hear the Ghost in the Closet-scene Hamlet says, according to QI, why see the king my father, my father, in the habite As he liued, looke you how pale he lookes, See how he steales away out of the Portall, Looke, there he goes.

This is composed for the most part of material from III iv I $34-6$ in the authentic text:

Why, look you there! look how it steals away!

My father in his habit as he lived,

Look where he goes, even now, out at the portal.

But the reporter has associated the second line here with a passage in Act I. In the latter part of $\mathrm{I}$ ii Horatio, Marcellus and Barnardo come to tell Hamlet of the first appearance of the Ghost: at lines I89-9I we have the following dialogue:

Hor. My lord, I think I saw him yesternight.

Ham. Saw, who?

Hor. My lord, the king your father.

Ham.

The king my father!

The reporter, remembering this last exclamation, has prefixed it to III iv I35, and produced a composite passage 


\section{I26 BLANK VERSE PECULIAR TO QI}

- "the king my father, my father, in the habite/As he liued".

We proceed to one of the most interesting passages in the first Quarto:

2ueene. Alas, it is the weakenesse of thy braine, xi 90

Which makes thy tongue to blazon thy hearts griefe:

But as I haue a soule, I sweare by heauen,

I neuer knew of this most horride murder:

But Hamlet, this is onely fantasie,

And for my loue forget these idle fits.

Ham. Idle, no mother, my pulse doth beate like yours,

It is not madnesse that possesseth Hamlet.

O mother, if euer you did my deare father loue,

Forbeare the adulterous bed to night,... .

We have already noticed one confusion with a passage concerning the Ghost in Act I. In the passage just quoted there are others. With QI xi 9 I and 98 compare I v 2 I-3 in the full play:

But this eternal blazon must not be

To ears of flesh and blood. List, list, $\mathrm{O}$ list!

If thou didst ever thy dear father love-

This is reproduced in QI as

But this same blazon must not be, to eares of flesh and blood Hamlet, if ever thou didst thy deere father loue....

(iv $83-4$ )

It is to the QI form of this that the reporter is indebted in xi 9 I and 98: this is indicated by the relative positions of the words "thou didst" and "ever", and by the prefixed vocative ("Hamlet"/"O mother"). This simply means that in the Closet-scene the reporter-versifier remembered material from Act I as it had previously been perverted in the "bad" text, whether by himself or another. His recollection of "blazon" quite apart from its immediate 
setting, and his alteration of that word from noun to verb, are analogous to other cases we have encountered.

QI xi 94 is also lifted, in slightly altered form, from the first Act. In I i 23, referring to the Ghost, Marcellus tells Barnardo that "Horatio says 'tis but our fantasy"; and in line 54 of the same scene, after the Ghost has appeared and then vanished, Barnardo asks Horatio, "Is not this something more than fantasy?" The situation here is the same as in the Closet-scene; Horatio is sceptical of the Ghost's objectivity just as the Queen is later. Note also the similarity of construction between "tis but...fantasy" and "this is onely fantasie".

In QI xi 95 the Queen talks of Hamlet's "idle fits". Both words are recollections from different passages in the authentic text. In III ii 88 Hamlet, referring to his assumed madness, says to Horatio "I must be idle" (that is, crazy). And in IV i 8 the Queen herself, referring to Hamlet's murder of Polonius, speaks of his "lawless fit"; and further on, in the graveyard, condoning Hamlet's ranting to Laertes, she says:

This is mere madness, And thus a while the fit will work on him.

(v i $278-9$ )

Thus QI xi 94-5 appear to have been manufactured out of reminiscences of three distinct passages in the full playline 94 from I i 23, "idle" from In ii 88, and "fits" from Iv i 8 or v i 279 . These materials have been supplemented by invention.

Consider in the next place Q1 xi 90 and 97. Taken together, they recall very strikingly two adjacent lines in QI scene vi, lines not found in the "good" texts. Corambis, describing the development of Hamlet's alleged madness, finishes with the lines

And so by continuance, and weakenesse of the braine Into this frensie, which now possesseth him.

(vi 93-4) 
The corresponding passage in the "good" texts runs

And he repelled...fell... into a weakness.... and into the madness wherein now he raves.

(II ii I $46 \mathrm{ff}$.)

The phrase "weakenesse of thy (the) braine" owes its existence in QI to a combination of elements extracted from II ii 148 ("weakness") and III iv I 37, where the Queen says to Hamlet, "This is the very coinage of your brain". The reporter confuses these two passages, and at both corresponding points in QI (vi 93 and xi 90) uses a combination of words selected from both.

In xi 97 the first five words ("It is not madnesse that") constitute what the reporter remembered of III iv I $4 \mathrm{I}-2$ :

\section{That I have uttered.}

it is not madness

When he wrote the words "that possesseth Hamlet" in xi 97 and "which now possesseth him" in vi 94, he may simply have been using his invention. ${ }^{\mathrm{I}}$ Just possibly, however, he may have vaguely remembered a passage in another play: consider, for example, Titus Andronicus, Iv i I 5-I 7:

Marcus. Canst thou not guess wherefore she plies thee thus?

Boy. My lord, I know not, I, nor can I guess,

Unless some fit or frenzy do possess her.

(Cf. "frensie" in QI Hamlet, vi 94.) Or consider King Fohn, v iii I 7:

Weakness possesseth me, and I am faint.

(Cf. "weakenesse" in QI Hamlet vi 93 and xi 9o.)

To continue with our analysis: in Q I xi 99 Hamlet bids his mother "Forbeare the adulterous bed to night". The

I Cf. I ii ${ }^{36-7}$ in the full play, where, speaking of the world, Hamlet says "things rank and gross in nature/Possess it merely". 
same instruction is contained in the authentic texts in quite different terms:

Good night, but go not to my uncle's bed,

and

(III iv I 59)

2ueen.

What shall I do?

Ham.

Not this by no means that I bid you do-

Let the bloat king tempt you again to bed....

(Ibid. 180-2)

"The adulterous bed" looks like a variation on "the incestuous pleasure of his bed", a phrase which occurs in the Prayer-scene (III iii 90, QI x 24). That this was in the reporter's mind when he composed his version of the Closetscene is proved by its repetition in QI xi 46. Now the word "incestuous" may have carried his memory back to I v 42, where the Ghost speaks of Claudius as "that incestuous, that adulterate beast". We have already noted other confusions with the first Act, and this may well be the explanation of "adulterous" in QI xi 99.

One or two small points remain. The words "thy tongue" in QI xi $9 \mathrm{I}$ are in all probability a reminiscence of the same words in III iv 39 in the full play. ${ }^{2}$ The words "thy hearts griefe" in the same line may also be rooted in other passages of the authentic versions: Hamlet's "grief" is mentioned, for example, in III i 180 and I86; in I ii 3 the King states that it befits the court "to bear our hearts in grief" for the elder Hamlet's death; and in III i I 76 the King refers to the unknown cause of Hamlet's madness as "this something-settled matter in his heart". It should also be noticed that QI xi 96 reproduces fairly closely the corresponding line in the "good" texts (III iv I40): it is the only case in the passage which we are examining where this can be said.

lids

he

rld, $\mathrm{x} 6$.

"Adulterous" also occurs in the QI version of the Prayer-scene,

2 Cf. also III iv $\mathrm{Ir}$.

D B $Q$ 
I have left two important lines without annotation. QI xi 92-3 are peculiar to that text and cannot be explained by the method which we have been using. The lines, spoken by the Queen, run as follows:

But as I haue a soule, I sweare by heauen,

I neuer knew of this most horride murder.

These will concern us when we come to consider the relationship of the Queen to the other characters in the "bad" Quarto."

In conclusion, the passage which we set ourselves to examine in this section ends with four lines which likewise refuse to yield to such an analysis as we have been conducting:

And win your selfe by little as you may,

In time it may be you wil lothe him quite:

And mother, but assist mee in reuenge,

And in his death your infamy shall die.

This passage also must be considered later. But here I would say that the fact that so much of the metrical blank verse peculiar to QI can be shown to have been composed by a reporter-versifier, and not to represent portions of either a pre-Shakespearian or an early Shakespearian Hamlet, means that we must guard against assigning any passage unique in QI to such a Hamlet unless there are positive reasons for doing so-reasons other than the fact that the passage is confined to the "bad" text. For as the ability of our reporter to construct regular blank verse came into play in fusing together fragments of text recollected from various points in the full play, so it could also be exercised from time to time in quite original composition.

One further point, now self-evident, must be emphasized. Passages of verse peculiar to $Q_{I}$ have no basis in any

I See Chapter vII, $\S$ III. 
authentic manuscript of the play at any stage in its texthistory. The above analyses themselves furnish a complete counter-argument to critics who, like von Westenholz, Hubbard, and de Groot, refuse to admit that the QI text is a piracy at all. They also disprove the hypothesis advanced by Professor Dover Wilson. ${ }^{1}$ He argued that the basis of the QI text was an authorized abridged transcript of the old Hamlet partially revised by Shakespeare. Passages of metrically regular verse found only in QI he regarded as unrevised portions of the old play which remained in the authentic transition-manuscript from which the abridged transcript was taken. Passages of QI in which the metre or verse-lining are flagrantly corrupt, and these only, he assigned to an actor who, from memory, made additions to the abridged transcript. ${ }^{2}$ But we are now in a position to say that metrically regular verse peculiar to $Q_{I}$ is pirate-work pure and simple, and that strong evidence of memorial reconstruction exists in passages which according to the Dover Wilson hypothesis stood in an authentic manuscript of the play at a certain stage in its text-history. These passages cannot in fact have stood in any such manuscript: and if only for this reason, I cannot see that we can at all accept the theory that such a manuscript underlies the $\mathrm{Q} I$ text.
I Library, 1918, pp. ${ }_{53}$ ff., 217 ff.
2 See also pp. r44 ff. 


\section{THE "MARCELLUS THEORY"}

Different explanations have been advanced for the fact that the earlier pages of the first Quarto give a text much fuller and closer to the authentic versions than do its later pages. Those who hold that QI presents the play in a transition state suggest that Shakespeare had begun revising the old play but had not proceeded very far. This is the view of the editors of the Clarendon Press Hamlet, of F. S. Boas, and of Professor Dover Wilson. But quite apart from the fact that the non-Shakespearian verse in QI (least frequent by far in the first Act) does not represent that of any preShakespearian Hamlet, or indeed any authentic Hamlet at all, but came into existence only during the compilation of that text, a decisive counterblast to the above hypothesis is provided by J. D. Fitzgerald, who suggests a practical experiment of great value. $\mathrm{He}$ advises his readers to concentrate upon the 300 lines or so at the end of QI which correspond to Act $\mathrm{v}$ of the full play, and to underline every word which appears in both. Of this part of QI two thirds, he claims, are rendered in the words of the genuine Shakespearian texts. ${ }^{I}$ It is quite true that throughout $\mathrm{Q}_{\mathrm{I}}$, from beginning to end, the greater part of the text (though not all of it) corresponds with varying degrees of proximity to those of the later editions. In carrying out this experiment proposed by Fitzgerald one must reckon with the frequent transference of words, phrases, and lines from one part of the full play to another part of the reconstructed version. If one takes a copy of QI, underlines every word which occurs in the corresponding scene in $\mathrm{Q}_{2}$ or $\mathrm{F}_{\mathrm{I}}$, and draws a dotted line under every word transferred from another

"The First 2uarto of "Hamlet": a Literary Fraud (rgro), pp. 5-6. 
scene in $Q_{2}$ or $F_{1}$, one finds that even in the last sheet of the spurious edition a remarkably small proportion of material remains without underlining of any sort. Behind $Q_{1}$ as a whole there lies either the $Q_{2}$ text itself or a version extremely close to it. There can be no sort of doubt about this. If the QI text indeed represents a partial Shakespearian revision of an earlier play, that revision already embraces the end as well as the beginning. To suggest, as the Clarendon Press editors do, that the Shakespearian revision had not proceeded far beyond the end of the second Act, is to betray an inadequate analysis of the "bad" text in relation to the others.

Upholders of the theory of a transition play behind QI might, however, suggest that Shakespeare's earlier revision, while extending through the whole play, was fullest and most careful towards the beginning. But the theory itself is more than endangered by the foregoing dissection of the non-Shakespearian verse in QI. That verse being pure pirate-work, and occurring less frequently towards the beginning of the play than towards the end, the fact which we have to face is a gradual deterioration in the accuracy with which QI represents the full text, a deterioration to be referred to the process of transmission rather than to conditions in the play underlying the bad Quarto itself.

This being so, serious consideration should be given to a point made by $\mathrm{Mr}$ Granville-Barker. He mentions as characteristic of the pirate the "fact that it is in the last third of the play that the text is most contracted and corrupt and the botching at its worst"; and he proceeds: "The last third of any play will be apt to suffer so at the hands of a man who fancies himself as - no poet of course, or 'serious' dramatist, but a practical man of the theatre. For there is nothing he so fears as the impatience of his audience once the excitement of a play's mid-crisis is past. After that push on quickly to the end, will be his rule. Now Shakespeare, writing generously throughout, is even 
more generous in the last third of the play, of incidental matter, and of what a 'practical' pirate might well consider 'mere talk'. Hamlet is absent from the action too; that the audience (and possibly the actor) may not like. And when he does return he has left emotional rhetoric-stuff, says the practical man, much to the taste of the audiencebehind him. Ample reasons here, then, for the extra contraction we find." I

There is doubtless much truth in this, and memory too may become gradually more and more exhausted. And supplementing all this, not excluding it, certain inequalities in the reporting have been accounted for by the hypothesis that one or more actors, who had taken minor parts in the stage version of the full play, were concerned in the effort of memorial reconstruction. Such actors would be more efficient with their own lines than with those of other characters, and more efficient as a whole with scenes in which they appeared than with others. It has been plausibly claimed that this principle is illustrated in the first Quarto of Hamlet.

As was noted in the Introduction, ${ }^{2}$ W. H. Widgery referred to the remarkable accuracy with which the small part of Valtemand (QI Voltemar) is presented in QI ${ }^{3}$ One of Professor Dover Wilson's most valuable contributions to the study of this text is his incontrovertible demonstration of the fact that this is due to the dependence of QI upon the manuscript part of the actor who took this rôle. ${ }^{4}$ He compares the text of Valtemand's long speech in QI (vi 3 I-5I) and FI (II ii 60-80), the latter text being set up from a transcript of the playhouse copy. 5 He notes

I Prefaces to Shakespeare, Third Series, p. 194.

${ }^{2}$ P. 26.

3 Harness Prize Essay, 1880 , p. ${ }_{3} 8$.

4 The Library, 1918, pp. 156-60.

5 For a full demonstration of the hypothesis that Fr Hamlet was printed from a transcript of the prompt-book see The Manuscript of Shakespeare's "Hamlet", vol. I, chap. 2. 
that there are only five small variations of reading, ${ }^{\mathrm{I}}$ and points to a textual agreement with $\mathrm{F}_{\mathrm{I}}$ against $\mathrm{Q}_{2}{ }^{2}$ Further connecting the $Q_{I}$ and $F_{I}$ versions of the speech is the punctuation. Shakespeare (directly underlying Q2), characteristically using light "dramatic" punctuation, has only two long pauses - a semicolon at the end of the first line (giving opportunity for " a bow of the ambassadors to the throne"), and a colon at the end of the twelfth ("which gives the Court an opportunity for the applause that naturally occurs at this point of the speech"). The "presiding genius at the Globe" (ultimately underlying F I), addicted to a heavy "rhetorical" punctuation, altered these to full stops, and introduced three new colons-at the end of the fourth and sixteenth lines, and in the middle of the tenth. In the QI version it is true that the two long pauses indicated by Shakespeare have degenerated into commas; ${ }^{3}$ but two of the three colons peculiar to $F_{I}$ are reproduced in Q1. From the bibliographical point of view, therefore, this remarkably accurate speech in $\mathrm{QI}_{\mathrm{I}}$ is related to the playhouse copy; and it is impossible not to conclude that it depends in fact upon the manuscript part copied from the playhouse copy.

Valtemand's manuscript part, or a transcript of it, was available to the compiler(s) of the QI text: but does it follow that an actor who had played the rôle was involved in the concoction of that text? Sir Edmund Chambers considers it improbable, contending that had the reporter

${ }^{I}$ Viz. I $Q_{1}$ returnes, $F_{1} Q_{2}$ returne; $2 Q_{1}$ forth, $F_{I} Q_{2}$ out; I8 $Q_{1}$ would, $F_{1} Q_{2}$ might; $19 Q_{1}$ that, $F_{r}$ his, $Q_{2}$ this; $20 Q_{1}$ allowance, $\mathrm{F}_{1} Q_{2}$ allowances. (The line-numbers are those of the speech.)

${ }^{2} Q_{1} F_{1}$ speak of "three thousand crowns", $Q_{2}$ of "threescore thousand crowns".

3 Upon this Dover Wilson comments: "Yet this change is not without its lesson, since, in copying, periods are more likely to become commas than the more conspicuous colon and semi-colon. This little piece of carelessness, therefore, connects with $\mathrm{F}_{\mathrm{I}}$ rather than with $\mathrm{Q}_{2}$." (Library, 1918, p. 159.) 


\section{I36 THE "MARCELLUS THEORY"}

indeed played it "he would not have corrupted the name into Voltemar". I One may wonder whether this is a valid objection, inasmuch as "Voltemar" may be not so much a corruption as a correction. As Dr Greg points out "there is no such name as Voltimand or Valtemand ${ }^{2}$ in Danish: it is presumably a corruption of Valdemar, and QI may indicate that the actors attempted to correct Shakespeare on the stage". 3 There is, however, another argument which militates strongly against the likelihood of an actor of the part of Voltimand having been implicated in the compilation of the QI text. At the end of the play QI presents us with the following remarkable stage-direction:

Enter Voltemar and the Ambassadors from England. enter Fortenbrasse with his traine.

(xviii ro8)

It is obvious that the character Voltemar is utterly out of place in this galley. In all probability the actor who had played Voltemar entered here as one of the English ambassadors. A reporter has remembered that this man came in at the end, but has unfortunately attached to him the name of a character he had enacted earlier in the play (hence separating him off from his English colleagues in this stage-direction). Had the actor himself been concerned in the memorial reconstruction he could not possibly have perpetrated this blunder or allowed a confederate to do so.

The excellence of the reporting of the Ghost-scenes in QI is a striking fact, and the theory that the reporter was an actor concerned in these scenes has been generally conceded. Indeed, if we disallow Professor Dover Wilson's

I William Shakespeare, vol. I, p. 416.

2 The spellings are: $Q_{I}$ Voltemar (twice); $Q_{2}$ Valtemand (twice); $F_{I}$ Voltemand (twice) and Voltumand (twice). The generally adopted form "Voltimand" does not appear until F2. See Greg, Aspects, p. 198 .

3 Aspects of Shakespeare, p. 198. 
I 9 I 8 hypothesis that an authentic manuscript underlies $Q \mathrm{I}$, we are surely forced to the conclusion that the reporter, or one of the reporters, was an actor involved in these scenes, this accounting for their specially good quality. The widely accepted "Marcellus-theory" was originated by Professor H. D. Gray, who announced it in an important article in The Modern Language Review for I9I 5. ${ }^{\mathrm{I}}$ There is no denying the extremely high standard of the reporting of his speeches, nor the fact that the general level of reporting is at its highest when he is on the stage. The very first page of QI illustrates the validity of the theory strikingly. Corresponding to I i I-I 3 of the full play QI gives us a miserable half-dozen lines, not one of which is accurate:

\section{Enter two Centinels.}

I. Stand: who is that?

2. Tis $I$.

I. O you come most carefully vpon your watch,

2. And if you meete Marcellus and Horatio,

The partners of my watch, bid them make haste.

I. I will: See who goes there.

Enter Horatio and Marcellus.

It is highly significant that the only two consecutive lines of the first thirteen in the "good" texts which are represented here are the lines which constitute the cue for the entry of Marcellus and Horatio ( 1 i I 2-I 3 : cf. QI i 4-5). Furthermore, QI i 3 (substantially reproducing I i 6) has been contaminated by an anticipation of a word in this very cue-passage - the word "watch" in I i I 3: for r i 6 runs

You come most carefully upon your hour.

And there is more to be said: for although it might be argued that the first line in $Q_{I}$ is compounded of elements

I The First 2uarto "Hamlet", pp. I71-80. 
from I i $I-2,{ }^{I}$ its construction has been influenced by I i I 4, where Francisco says "Stand ho, who is there?" And this is in the first line spoken after the entry of Marcellus and Horatio. It seems, therefore, that the wretched makeshift dialogue which in QI represents the thirteen lines spoken in the "good" texts before this entry has been manufactured principally from the two lines preceding it and the one following it in the authentic texts. But immediately these two characters enter in $Q_{I}$, just after line 6 , the quality of the text soars. Francisco and Barnardo, involved from the beginning, would make poor candidates for the rôle of reporter; Horatio is involved throughout the play, as Hamlet is, and yet from the end of the first Act the quality of the text deteriorates in QI. Marcellus is the obvious choice for the position of actorreporter; and everything seems to conspire to corroborate this impression. I am content to rely on Professor Gray's easily accessible argument.

"Marcellus" appears also in Professor Dover Wilson's hypothesis, but for a different reason. This was one of the rôles he allocated to the pirate-actor who, from memory, made interpolations in the authentic abridged transcript of the old Hamlet partially revised by Shakespeare, which, according to the hypothesis, underlies the QI text. ${ }^{2}$ The reason for this allocation was not the excellence of the character's speeches in the spurious edition, nor the higher level of accuracy in the scenes in which he appears. For these speeches, and indeed the bulk of the QI text of these scenes, figured in the transcript itself. Moreover, in the course of the partial revision to which Shakespeare had subjected the old play before the said transcript was made, the scenes in which Marcellus appears (scenes in the early part of the play) had already been brought near their final

I Bar. Who's there?

Fran. Nay, answer me. Stand and unfold yourself.

2 See pp. 13 I and $144 \mathrm{ff}$. 
state. What made Professor Dover Wilson decide that the pirate-actor played Marcellus was the presence in $\mathrm{Q}_{\mathrm{I}}$ of metrical and structural deficiencies in the scenes in which he appears. These irregular passages could not have stood in the transcript and must, he thought, be interpolations made from memory. The pirate-actor would be most likely to make interpolations at points where he himself was on the stage. And by a process of elimination of the other characters involved in the "Marcellus-scenes", Marcellus himself was identified as the reporting actor. Had he been Hamlet or Horatio he would have interfered at points in QI where these characters appear but where in fact Professor Dover Wilson found no mark of his hand such as faulty metre and mislineation; nor could he have been Barnardo or the Ghost, since these parts "would have given him too little scope for the work he does", and since marks of his hand were discovered at points where these characters are not present. ${ }^{\mathrm{I}}$

But since we are compelled to repudiate the hypothesis of the partial dependence of $Q$ I upon an authentic manuscript, ${ }^{2}$ and since we must therefore account in some other way for the peculiar excellence of the "Marcellus-scenes" as a whole and of his speeches in particular, it seems that we must implicate an actor who had taken the part-but for the reasons adduced by Professor Gray, not those of Professor Dover Wilson. Furthermore, it is quite certain that Marcellus's manuscript part was not used; for Gray lists a considerable number of small errors in his speeches in Q1.3 These variations are too insignificant to be attributed to an intervening revision, but too frequent to allow of a theory of transcription. The case is here the same as with the part of the Host in the "bad" Quarto of The Merry $W$ ives of $W$ indsor. 4

${ }^{1}$ Library, 1918, p. 172 .

${ }^{2}$ See p. $\mathrm{I}_{3} \mathrm{I}$ and also pp. $145-9$.

3 Modern Language Revierw, vol. x, 1915, p. 176, note.

4 Cf. Greg, Merry Wives, I602, introduction, p. xxxvii. 
Marcellus does not appear in the play after Act I, and we cannot suppose that the actor would not also have taken another part or other parts. I am inclined to agree with Gray that he also took the part of the murderer Lucianus in the Gonzago play, since the speech corresponding to III ii $255-60$ is conspicuously accurate in QI.

Implicated in the concoction of the spurious text, then, we have actor-reporter and reporter-versifier, and the hypothesis of Tycho Mommsen and Gray is vindicated. But I can see no insuperable objection to the view that here we have to deal with one agent only, an actor-reporter-versifier. Considering a similar question with regard to the pirated version of The Merry Wives Dr Greg admits that "it may even be that the version was concocted in collaboration by the actor and a reporter", but sees "no justification for conjecturing two agents where one will suffice". I

If two hands are postulated in the preparation of the QI text, as they are by Professor Gray, the one will be held responsible for the passages of verse, structurally regular for the most part, which are not directly related to the corresponding passages in the authentic texts, which do not simply represent attempts at reproducing the latter, and which have been created once and for all during the concoction of the text: this is the hand of the reporterversifier, Professor Gray's hack-poet. The other hand will be held responsible for the countless passages, often structurally irregular but not invariably so, which are directly related to the corresponding passages in the "good" texts and which do represent attempts at reconstructing the latter: this is the hand of the actor-reporter. But Signor - Ramello ${ }^{2}$ has pointed out a certain stylistic homogeneity between the two types of writing in QI. In particular he mentions recurring words and phrases which appear indifferently in both. Let us take a few examples.

I Greg, Merry Wives, 1602 , introduction, p. xli.

2 Hamlet, 1603, pp. I41-53. 
I have shown that $Q I$ vi $I-I 8$ comes into the first of the two categories mentioned above. The first three lines run as follows:

\section{...that our deere cosin Hamlet \\ Hath lost the very heart of all his sence, \\ It is most right, and we most sory for him.}

The construction and phraseology of this passage is closely copied in xiii $57-8$ :

...that your father is murdred,

'T'is true, and we most sory for it.

These two lines are embedded in a passage (xiii 46-68) which is closely related to, and obviously a direct attempt at reproducing, the corresponding part of the authentic text, viz. IV v I I $2-53$.

Similarly, in vi 7 we have "the cause and ground of his distemperancie", and in viii 26-7 (a passage of irregular structure, but embedded in a scene clearly in the first category announced above) we have "the very ground/ Of his distemperance". Compare two passages in QI which come into the second of our two categories: (i) At vii 54 we find "the cause and ground of your discontent"; this occurs in a passage (vii 39-88) which directly corresponds to, and is an obvious attempt at reproducing, II ii $223-383$ of the authorized text: (ii) At ix I 89 we find "the ground and cause of your distemperature"; this occurs in a passage (ix I84-2II) which is similarly a direct attempt at reproduction of III ii $29 \mathrm{I}-374$.

Thirdly, there are three passages in $\mathrm{Q}_{\mathrm{I}}$ of the first category where the word "change" is used in reference to characters gone mad (v 33, vi 20I, xiii 4I). Similarly, at vi 186 we have "Alas, what change is this?", a line which occurs in a passage (vi I I 7-200) which directly corresponds to, and is an attempt at direct reproduction of, III i 56-I 52 in the authentic text. 
Again, in viii $18-19$ (part of a scene unquestionably in our first category) we have the following:

... and what the Queene of Denmarke

May pleasure you, be sure you shall not want.

This is directly indebted to an earlier passage in QI (iv 228-9):

And what so poore a man as Hamlet may,

To pleasure you, God willing shall not want.

This latter is a clumsy attempt at reconstruction of I v $184-6$ :

And what so poor a man as Hamlet is

May do t'express his love and friending to you

God willing shall not lack.

It is to the QI form of this passage that the reporter is indebted in viii $18-19$. Once more we have a clear phraseological link between a passage by "reporterversifier" and a passage by "actor-reporter". For the whole of QI scene iv is direct reconstruction of the corresponding material in the authentic versions.

These are examples of the method used by Signor Ramello in arguing that his "corruttore" and "compilatore" (our "actor-reporter" and "reporter-versifier" respectively) were the same person. His strongest point is perhaps the purely general one, that the two categories of writing which have been noted in QI are often so very closely interwoven that it is most reasonable to postulate single authorship for the bulk of the text. A full appreciation of this naturally depends upon a complete examination of Q1. Sufficient to say here that Ramello's evidence does much to impel one to an economy of hypothesis which is in itself desirable.

But in a review of Ramello's book ${ }^{\mathrm{I}}$ Gray, upholding his ${ }^{1}$ Modern Language Notes, vol. XLvi (1931), pp. 410-2. 
own theory of two separate reporting agents (actor and hack-poet), advances an explanation of this intimate interweaving of the two styles, an explanation consistent with his hypothesis. He believes that the hack-poet not only interpolated passages of his own composition to fill gaps in the actor-reporter's version, but also revised that version to some extent: thus, where we find traces of his hand in passages which substantially reproduce the corresponding material in the authentic texts, we may suppose that he was merely revising, amplifying, or rephrasing the work of the actor-reporter. This would account for the verbal parallels just mentioned. Professor Gray asks why there should be such a pronounced alternation of structural method in QI if a single hand is responsible for the whole text. If the reporter could, and sometimes did, write regular blank verse of his own, why did he not do so consistently when he could not exactly reproduce the Shakespearian structure? It is a pertinent question, which we might however counter by asking Professor Gray why his revising hack did not regularize the metre of the entire text handed to him by the reporting actor. The most reasonable general hypothesis seems to be that the bulk of the QI text is the work of a single reporter, who, when he had a fairly clear recollection of both the content and the wording of material in the full play, strove to reproduce it without very much regard for metre (or even sense at times), but who, when he could remember only (or chiefly) the general drift of a passage in the full play, rendered it in regular blank verse of his own composition, often stringing together words and phrases gleaned from his memory of various passages strewn throughout the authentic text.

But even granting that the actor-reporter and reporterversifier may well have been the same person, there is some evidence suggesting the implication of another hand in the transmission of the QI text. This will concern us in the next chapter. 


\section{THE COMPOSITE NATURE OF THE COPY FOR QI}

Mention has already been made of Professor Dover Wilson's hypothesis of QI Hamlet and its relationship to the texts of $\mathrm{Q}_{2}$ and $\mathrm{F}_{\mathrm{I}}$, a hypothesis which we must now consider in greater detail. He called attention to certain marked bibliographical links between $\mathrm{Q}_{1}$ and $\mathrm{Q}_{2}$, these being confined to the first two Acts. Since $Q_{2}$ was printed from Shakespeare's autograph, ${ }^{\mathrm{I}}$ Professor Dover Wilson argued that QI was printed from an abridged transcript of the same autograph in an earlier state. But throughout the QI text there are passages in which the metrical structure breaks down entirely. These could hardly have stood in a Shakespearian manuscript at any stage in its evolution, and Professor Dover Wilson attributed them to a pirate-actor who, relying on his memory alone, made interpolations in the transcript. To state the hypothesis more fully: QI was printed from an abridged transcript of the old Hamlet, made in I 593 when that had been only partially worked over by Shakespeare, whose revision had not extended much further than the ghost-scenes. This abridged transcript was used as a prompt-copy during an extended provincial tour undertaken by Shakespeare's company in that year. In I603 it was used as the basis of the QI edition: but meanwhile Shakespeare had completed his revision in the original manuscript, which in its final state became the copy for $\mathrm{Q}_{2}$ in $\mathrm{I}_{604}$. The $\mathrm{Q}_{\mathrm{I}}$ publishers employed a minor actor to bring the 1593 transcript more up to date by

I This was later fully proved in Dover Wilson's The Manuscript of Shakespeare's "Hamlet" (r934); see especially vol. I, chap. 3 . 
interpolating from memory such passages as he could remember from the full play in which he had taken a number of small parts. This actor inserted or substituted passages in scenes in which he himself had been involved on the stage.

Now let us consider the postulated transcript of 1593 . Those passages of $Q_{I}$ with regular metre which are not directly related to the corresponding passages of $Q_{2}$ were explained by Professor Dover Wilson as "fragments of the 'ur-Hamlet' over which Shakespeare had not yet worked". I He asserted categorically that "there was no hack poet". I We saw in chapter Iv that this view is quite wrong. The non-Shakespearian portions of $\mathrm{Q}_{\mathrm{I}}$ which have regular metre are the work of a reporter capable of versification, and never stood in the Ur-Hamlet or any other.

But what of the bibliographical links between QI and Q2 in the early scenes of the play? One was the use of inverted commas in QI iii 27-36,39, 66-7, 70; QI scene iii corresponds to I iii in $\mathrm{Q}_{2}$, in which text inverted commas are also found, though not at the same points. Professor Dover Wilson argued that both sets came ultimately from the same dramatic manuscript, and that between the time when the I 593 transcript was made and the time when $\mathrm{Q}_{2}$ was printed the text of the scene had been revised and the position of the inverted commas changed. But in chapter IV, $\S \mathrm{III}$, we saw that QI iii $66-7,70$ are the work of a reporter; thus the inverted commas throughout the scene may safely be attributed to him. We may assume that he was familiar with this device used by dramatists to mark "sententiae". If he had some connection with the theatre he would have seen examples time and again in playhouse manuscripts.

Again, Professor Dover Wilson stressed as significant the fact that in two passages in the first act in QI brackets are used in the same way as in $Q_{2}$, though again not at the

$$
\text { I Library, 1918, p. 163. }
$$


same points. He distinguishes the use of brackets in $\mathrm{Q}_{2}$, printed from Shakespeare's own manuscript, and in F $\mathrm{I}$, printed from a transcript of the prompt-book. "The $\mathrm{Q}_{2}$ brackets", he says, ${ }^{\mathrm{I}}$ "are almost invariably dramatic in intention, i.e. they imply a change in intonation and generally some kind of mental or spiritual disturbance, which may be comic in the case of Polonius for example, or tragic in the case of Hamlet. The brackets in $\mathrm{F}_{\mathbf{I}}$ are equally invariably grammatical or rhetorical in meaning; they denote parenthetical utterance and nothing more, and are most frequently found with little qualifying or explanatory clauses, such as, 'they say', 'as I think', 'for the most part'. 'Drop the voice' is, I think, a fair interpretation of their significance. Contrast with these the following beautiful example from $Q_{2}$, where the brackets simply vibrate with the tones of mystery and amazement:

My fathers spirit (in armes) all is not well.

It is a perfect piece of dramatic pointing, the brackets forming, as it were, the curb-stone of a well, over which we bend to peer down into the depths of Hamlet's soul."

The two examples of the use in QI (Act I) of brackets similar in intention to those of $\mathrm{Q}_{2}$ are, first in ii 77 :

I am very glad to see you, (Horatio) or I much forget my selfe. and secondly, iv I46, where the words "My tables" are bracketed. Of the first case Professor Dover Wilson says: "The opening soliloquy has just finished, leaving Hamlet so overwrought and his eyes so full of tears, that when Horatio, the friend of his bosom, appears, he does not - recognise him. 'I am very glad to see you,' he begins politely as to a stranger; and then he springs at him with a cry of joy, 'Horatio!- or I much forget myself." ${ }_{2}$ Of the second case he says: "'My tables,' accompanied by a wild hysterical chuckle, is an example of spiritual disturbance if

$$
\text { I Op. cit. p. 16r. }
$$$$
2 \text { Ibid. p. } 162 .
$$ 
ever there was one in dramatic literature, and the brackets of QI, occurring at the beginning of the line and initiating a new idea, express the dramatist's intentions with the precision of musical notation. And yet we are asked to believe that these exquisite touches were captured and registered by a reporter taking notes in the theatre!" I But let us look at the second passage more closely:

Yes, yes, by heauen, a damnd pernitious villaine,

Murderons, bawdy, smiling damned villaine,

(My tables) meet it is I set it downe,

That one may smile, and smile, and be a villayne;...

(iv I 44-7)

The first two lines are metrically regular, and using Professor Dover Wilson's criteria there is no reason to suspect that on his hypothesis they did not stand in the 1593 transcript. Yet they provide clear evidence of a memorial element in their transmission. The corresponding lines in the authentic text run:

O most pernicious woman!

-yes by heaven!

$O$ villain, villain, smiling, damned villain!

( I v ro4-6)

In the first line in QI the writer anticipates "damned" in the next line, another result of the anticipation being the substitution of "villaine" for "woman". One glance at the passage in QI is enough to show that the anticipation was not of the eye but of the memory. The second line is even more direct in its evidence. The words "smiling, damned villaine" come directly from the corresponding line in the authentic text; but the string of different epithets applied to "villaine" owes its existence here to anticipation of a passage in the "rogue and peasant slave" soliloquy:

Bloody, bawdy villain!

Remorseless, treacherous, lecherous, kindless villain!

${ }^{1}$ Op. cit. pp. 162-3.

(II ii 583-4) 
The word "bawdy" itself testifies to the anticipation. The line containing one of the sets of brackets which Professor Dover Wilson took as rooted ultimately in the same manuscript as that behind $\mathrm{Q}_{2}$ is immediately preceded by two equally metrical lines which give evidence of having been composed from memory. We must suspect his derivation of the brackets, assuming that the reporter (presumably a man of the theatre) was acquainted with the device and its dramatic purpose. That the one set of brackets is dismissed as evidence of derivation from a Shakespearian manuscript means, of course, that the other set is valueless, since it too may be attributed to the reporter. But not a reporter taking notes in the theatre: QI Hamlet is a memorial reconstruction.

Consider now the other classes of bibliographical link between $Q_{1}$ and $Q_{2}$. There is a large number of identical spellings in the early scenes: Professor Dover Wilson takes as an example Q2 I i 58-79, and sets this beside the corresponding passage in QI (i 54-75). Despite variations, there is a striking amount of agreement in spelling, suggesting to Professor Dover Wilson derivation from a common manuscript at different stages in its development. And there are other examples. Even more interesting than coincidence in unusual spellings between $Q_{1}$ and $Q_{2}$ is coincidence in misprints, whether identical or merely similar. I This suggested to Professor Dover Wilson misreading of the same manuscript at different stages in its development-misreading by the I 593 transcriber and by the $\mathrm{Q}_{2}$ compositor. The great majority of these agreements in uncommon spellings and in misprints occur in the first act: ${ }^{2}$ the reason given for this was that by 1593 Shakespeare's reworking of the old play had not proceeded much further than that.

I See Library, I918, p. I66; see also note 2 below.

2 For a list of spellings and misprints common to the two Quartos in Act I see The Manuscript of Shakespeare's "Hamlet", vol. I, p. ${ }_{59}$. 
By 1934 Professor Dover Wilson had become sceptical of his I9 8 theory of the origin of the QI text; and in his Manuscript of Shakespeare's "Hamlet" I he advanced another explanation of the bibliographical connection between $Q_{1}$ and $Q_{2}$. According to this new hypothesis, the $Q_{2}$ compositor, finding Shakespeare's hand difficult at times, consulted the QI text, making use of it for the most part only in the first act where it was closer to the authentic text than elsewhere. Since we have been compelled on independent grounds to reject the I 9 8 hypothesis, this explanation of the common misprints and unusual spellings in the two Quartos is in all probability the correct one. If so, $Q_{2}$ Hamlet in this respect resembles $Q_{2}$ Romeo and 7 uliet. ${ }^{2}$

As has already been said, the I9I 8 theory postulated a composite manuscript behind $Q_{I}$, the first stratum consisting of the abridged transcript of the partially reworked Ur-Hamlet, the second of memorial interpolations by a pirate-actor. The hand of the latter was recognized by criteria which included metrical irregularity and structural ineptitude. The transcript theory will not stand; except for one passage (vi $3 \mathrm{I}-5 \mathrm{I}$ ), memorial transmission can be detected throughout the QI text. But I believe that certain portions of the work of our actorreporter-versifier were subjected to a revision, and that the reviser made some additions to the original reconstruction. Both the original reporter and the interpolating reviser were working from memory: it is consequently rather daring to point to a given passage and declare that it is an

${ }^{1}$ Pp. $15^{8-62 .}$

2 See R. Gericke, Shakespeare Fahrbuch, vol. xIv (1879), pp. 26972 ; G. Hjort, Modern Language Review, vol. xxI (1926), pp. 140ff.; W. W. Greg, Aspects of Shakespeare (1933), pp. 144-7, 175-81 (reprint of British Academy Shakespeare Lecture, 1928). Miss Hjort thinks that $\mathrm{Q}_{2}$ Romeo and $\mathcal{F}_{\text {uliet }}$ was printed throughout from a corrected copy of $\mathrm{Q} r$; Dr Greg limits this to the first two sheets. But the bibliographical dependence of $Q_{2}$ upon $Q_{1}$ in certain passages is an established fact. 
interpolation subsequent to the main report. Metrical irregularity, for example, is not for us an automatic criterion of interpolation, as it was for Professor Dover Wilson in I9I8: for if the text is indeed composite both strata represent memorial work. There is one scene, however, namely, scene xiv, where a structural breakdown occurs which seems to me significant. Let us examine this in some detail.

\section{I \\ (QI Scene xiv)}

Whether or not any conversation such as this between Horatio and the Queen took place in any authentic Hamlet play, we need have no hesitation in attributing the actual lines of QI scene xiv to the reporter-versifier whose work we have been studying. He gives himself away in a most obvious fashion in one of the lines with which we are here especially concerned.

From the structural point of view three blocks of text can be distinguished in the scene. The first seventeen lines are metrically regular and correctly divided. The same is true of the last ten. Between lies a passage of nine lines in which both metre and line-division are disturbed. In my belief this structural disturbance has significance.

The irregular passage is printed thus in $\mathrm{Q}_{\mathrm{I}}$ :

\section{(Hor.)}

To morrow morning.

Queene. O faile not, good Horatio, and withall, comA mothers care to him, bid him a while [mend me Be wary of his presence, lest that he Faile in that he goes about.

Hor. Madam, neuer make doubt of that:

I thinke by this the news be come to court:

$\mathrm{He}$ is arriv'de, obserue the king, and you shall

Quickely finde, Hamlet being here,

Things fell not to his minde.

(xiv $17-26$ ) 
Within this passage there are two separate patches of metrical and structural irregularity, kept apart by Horatio's words "Madam, neuer make doubt of that", which may be regarded as a legitimate extra metrum ejaculation, and by the line immediately following, which is perfectly metrical and correctly set up as a single line.

At one point immediate restoration of the correct linedivision is possible:

Bid him a while be wary of his presence,

Lest that he faile in that he goes about.

It is quite clear that here we have two correctly metrical pentameters conceived and written as such. And in the first we have evidence in plenty that our reporter-versifier is responsible; for it is composed of fragments gathered from no less than three separate passages earlier in the play. In II $i 70$ of the authentic Shakespearian text Polonius says to Reynaldo, "And let him (i.e. Laertes) ply his music". This is rendered in QI v 3 as "And bid him ply his learning", and again, at the end of the same scene (line 30), "And bid him ply his musicke". Here a parent is sending instructions to a son through a third party, just as in Q 1 scene xiv. Secondly, consider $\mathrm{Q}_{2}$ I iii 43 , where Laertes warns Ophelia to "Be wary, then-best safety lies in fear...". And thirdly, consider I iii I2I, where Polonius gives Ophelia this instruction:

Be something scanter of your maiden presence.

Placing the line which we are examining in QI scene xiv beside these three earlier lines, I cannot see how the conclusion can be avoided that the former was not derived from the old Hamlet or from an early Shakespearian Hamlet, but was composed by someone who was drawing on his memory of earlier passages in the full version and of an earlier passage of his own wording (also founded, however, upon $\mathrm{Q}_{2}$ ): 
Bid him a while be wary of his presence

bid him ply his learning...

Be wary then,....

Be something scanter of your maiden presence

(QI xiv I9-20)

(QI v 3)

(Q2 I iii 43)

(Q2 I iii I 2 I)

And there is other evidence that the reporter-versifier was responsible for the bulk of the scene. ${ }^{\mathrm{I}}$ Some of this evidence is brought forward by J. D. Fitzgerald, ${ }^{2}$ who shows that "his memory is unconsciously haunted by scraps of the original text, so much of which he was compelled to omit". Let us have a full analysis.

Horatio addresses the Queen as "Madame" in line I: in the accredited texts she is so addressed by Ophelia in III i 42 and by Polonius in II ii 86 and 96. Speaking to her, Horatio refers to Hamlet as "your sonne": in the full play the King uses the same mode of reference in In ii 55 , IV i 3 , IV v 79, and vi $290^{3}$ (but the reporter makes no use of the special point of the words there; the King uses them in a hostile sense, dissociating himself from responsibility for and to Hamlet). Still in the first line of the scene, Horatio says that Hamlet is safely "arriv'de in Denmarke": this seems to be a combination of words from v ii $374-5$, where Horatio says to the English ambassadors "you from England/Are here arrived", and v ii 8r, where Osric says to Hamlet "Your lordship is right welcome back to Denmark". In QI xiv 2 Horatio says that he has received a letter from Hamlet: doubtless the reporter is remembering the letter Horatio receives in IV vi in the authorized texts. QI xiv 2 runs, in full, "This letter I euen now receiv'd of him": here the reporter may have remembered and applied to his own purposes words found in IV vii 40-I, where, the King having asked who had

${ }^{I}$ I.e. for the dialogue. The staging is another problem.

"The First 2uarto of "Hamlet": a Literary Fraud (19ro), pp. 39-40.

3 Cf. also II ii 92 . 
brought the letters from Hamlet to him and the Queen, the Messenger says "They were given me by Claudio, he received them/Of him that brought them"; and possibly the reporter remembered the isolated phrase "even now" from III iv I 36. In the letter described in Q1 xiv Hamlet describes "how he escap't the danger" plotted by the King: in the authentic texts, in his later design against Hamlet, the King plans to poison him "If he by chance escape your (i.e. Laertes') venomed stuck" (IV vii I60); and the reporter has also caught up the phrase "by chance", employing it in xiv 3 I ("by great chance"). The "Packet" mentioned in xiv 6 and 29 is that referred to in v ii I 5 in the full play.

At the end of Horatio's first speech in scene xiv we find a promise of later explanation, a promise not fulfilled in the text:

As at his next conuersion with your grace,

$\mathrm{He}$ will relate the circumstance at full.

(xiv 8-9)

It is interesting to find that in the authorized texts Hamlet promises full explanations both in his letter to Horatio (Iv vi $23 \mathrm{ff}$.) and in that to the King (rv vii $43 \mathrm{ff}$.). The reporter may have had this in the recesses of his mind. Note also that in the two lines quoted there are two specific verbal debts to the authentic texts: the Queen is addressed as "your grace" in III iv 3; and in $\mathrm{V}$ ii 2 Hamlet, speaking of that part of his story which he has already told Horatio, says "You do remember all the circumstance?"

The Queen's first speech begins with two lines in which practically everything can be traced to other passages:

Then I perceiue there's treason in his lookes

That seem'd to sugar o're his villanie: (xiv IO-I I)

There is a confusion here with the play-scene. Fixing on his plan for producing the Gonzago play before the King, 
Hamlet says "I'll observe his looks" (II ii 600): but the reporter also seems to have remembered the construction of an earlier passage where Hamlet, attempting to force from Rosencrantz and Guildenstern an admission that they had been sent for, says "there is a kind of confession in your looks" (Ir ii 282). Confusion with the play-scene is further attested by the word "perceiue": compare III ii 287 , where, after the court has broken up in disorder, Hamlet triumphantly asks Horatio "Didst perceive?" referring to the King's conduct and looks "upon the talk of the poisoning'). The second line of the Queen's first speech in Q1 xiv yields equally well to analysis. The word "villany" is used in reference to the King's plots against Hamlet in v ii 29 and 309; and the word "villain" is applied to him in I v 106 and 108 , I ii $583-4$, III iii $76-7$, and III iv 96. The phrase "sugar o're" occurs in the authorized texts in III i 48 , where Polonius, having set the stage for the "nunnery" scene, has a momentary twinge of conscience:

'Tis too much proved, that with devotion's visage And pious action we do sugar o'er

The devil himself.

In xiv $15-17$ Horatio informs the Queen that Hamlet

hath appoynted me

To meete him on the east side of the Cittie

To morrow morning.

In the full play Hamlet writes three letters. One is to his mother and of its contents we hear nothing. ${ }^{\mathrm{I}}$ Another is to the King, and contains the words "Tomorrow shall I beg leave to see your kingly eyes" (Iv vii 44). The third is to Horatio, containing the direction "repair thou to me with as much speed as thou wouldest fly death" (IV vi 23). The time-sequence here is completely in accordance with 
dramatic propriety. No sooner has he landed than Hamlet wants to speak with his only confidant. He is prepared, after the "interim" which is his, to go to the King, ready at last to accomplish his task. In QI, on the other hand, there is a gap of over a night with no dramatic significance. Hamlet waits all this time before seeing his nearest friendand there is absolutely nothing for him to do in the meanwhile. It is clear that the reporter has confused the contents of the letters written by Hamlet to the King and to Horatio in the received text: he has transferred the time of Hamlet's appointment with the King to that of his appointment with Horatio, thereby damaging dramatic coherence.

In QI xiv 28 Horatio describes the fate of Rosencrantz and Guildenstern: "He (i.e. Hamlet) being set ashore, they went for England". Here the reporter has put together portions of two separate lines in the full play: at Iv vii 43 Hamlet, in his letter to Claudius, says "I am set naked on your kingdom"; and at IV vi 27 , at the end of his letter to Horatio, he says "Rosencrantz and Guildenstern hold their course for England".

The words "writ downe" in xiv 29 recall the same words in I ii 222 of the authorized texts: ${ }^{\mathrm{I}}$ and for "his fathers Seale" the reporter has drawn on his memory of $v$ ii 49-50, where Hamlet says:

I had my father's signet in my purse,

Which was the model of that Danish seal.

his

There can be no doubt, then, that substantially the dialogue of scene xiv is to be attributed to the reporterversifier for whose complicity in the production of the QI text we have already argued. It is not a remnant of the Ur-Hamlet, nor a portion of a Shakespearian first draft. Let us now return to the irregularly constructed passage in this scene, i.e. lines $18-26$.

I In QI (ii I 34 ) this is corrupted into "right done". 
In those parts of QI which correspond to the first Act of the full play there are passages where, although the words fairly accurately reproduce those of $Q_{2}$, the lines are misdivided. In such cases the mislineation has arisen during an attempt to reconstruct an original from memory. But when he composed the two lines in scene xiv which we have restored above to their true lineation the reporter was manifestly not striving to reproduce an original: he was building up a version of his own. Why then should he flagrantly misdivide two of his own pentameters? Both here and later in our examination of this irregular passage it is mislineation which I would principally stress as being significant. One might also ask, however, why his metre itself should suddenly collapse in a passage of his own invention, owing nothing to any corresponding passage in Shakespeare, but concocted from various fragments assembled for the purpose. In such circumstances he usually produces scrupulously regular verse.

The explanation which I wish to offer is that the structure of the reporter-versifier's work has been destroyed by an interpolation made in the course of a revision of his verse. The phrase "O faile not, good Horatio" satisfactorily completes the line begun by Horatio's concluding words "Tomorrow morning"; and the disarrangement is neatly accounted for if we suppose that the phrase "and withall, commend me a mothers care to him" is an interpolation. What the reporter-versifier wrote, then, was this:

Hor. Yes Madame, and he hath appoynted me To meete him on the east side of the Cittie To morrow morning.

2ueene.

O faile not, good Horatio,

Bid him a while be wary of his presence, Lest that he faile in that he goes about.

I suggest that an interpolator wrote "and withall, commend me" in the right-hand margin immediately after 
"good Horatio", and that he wrote "a mothers care to him" in the left-hand margin immediately before "Bid". The compositor began by following his copy, setting up as one line the words "O faile' not, good Horatio, and withall commend me". But after this he was faced with a huge line - " a mothers care to him bid him a while be wary of his presence". He had already turned down the last two syllables of the preceding line, and he could not fit this very long line into the available space. It looks as if he had started at the beginning of this monstrous line ("a mothers care... '), carefully counted five iambic feet (which brought him to the word "while"), and treated that as a line; then, beginning with "be wary" he counted another five feet, which brought him to "lest that he", giving him another line; and finally, left with a few words at the end of the speech, he was forced to set them up as a metrically defective line.

If our reconstruction of the original state of the reporterversifier's text is correct, there was good reason for the subsequent insertion. At the end of the scene the Queen says:

Horatio once againe I take my leaue,

With thowsand mothers blessings to my sonne.

(xiv 34-5)

But not even in the text as it stands in the Quarto has she previously taken her leave in this scene. And the only passage which could be regarded as implying a preliminary farewell is precisely the words "and withall, commend me a mothers care to him", which on our hypothesis constitute an interpolation. In the original stratum of this text, therefore, Gertrude specifically took a second leave without having taken a first. I suggest that a reviser remedied this by inserting an implied leave-taking at a suitable point earlier in the scene. That the wording of the interpolation echoes that of the passage at the end which made it necessary 
is not surprising. Indeed, it corroborates our impression of the reason for the addition: the reviser read the Queen's last speech, realized the error which the reporter-versifier had made, and, working without any document by which to make corrections, inserted similar but less extravagant words at an earlier point. "A mothers care" I corresponds to "thowsand mothers blessings", and "to him" parallels "to my sonne".

The other patch of faulty metre and line-division in the irregular nine-line passage consists of the following lines:

I thinke by this the news be come to court:

$\mathrm{He}$ is arriv'de, obserue the king, and you shall

Quickely finde, Hamlet being here,

Things fell not to his minde.

(xiv 23-6)

The presence of the words "finde" and "minde", embedded in this passage, shows that originally a rhymed couplet stood at the end of this short speech. Obviously the second line of this couplet is

Hamlet being here, things fell not to his minde.

Inasmuch as line 23 is perfectly regular as it stands, the first line of the rhymed couplet is over-long. We may begin by rearranging the passage thus:

I thinke by this the news be come to court:

$\mathrm{He}$ is arriv'de, obserue the king, and you shall quickely finde, Hamlet being here, things fell not to his minde.

From the examples of his work which we have already examined, we may surely impute to the reporter-versifier sufficient technical skill to enable him to construct a metrical and correctly divided rhymed couplet, when he is,

I For the word "care" the interpolator may have been indebted to QI vi 5 and/or xi ${ }_{155}$, at both of which points the reporter-versifier had used the word in connection with parental solicitude for Hamlet. See p. 93 . 
as here, relying upon his invention and not striving to reproduce some half-forgotten passage of Shakespeare. Apart from the general improbability of his giving one line of a rhymed couplet four extra syllables, the passage cannot have stood as rearranged above in the copy for $\mathrm{Q}_{\mathrm{I}}$ : for had that line-division been indicated the compositor would presumably have set it up so, tucking the end of the long line into the space at the end of the following one with a bracket. The mislineation in the Quarto must be due to mislineation in the compositor's copy, and again I suggest interference there by an interpolator.

If we wished to make the original stratum read as intelligibly as possible with the material given in the Quarto, we might conjecture that it ran thus:

I thinke by this the news be come to court:

Obserue the king, and you shall quickely finde,

Hamlet being here, things fell not to his minde.

This is quite coherent, and correctly constructed. The interpolator would on this assumption have inserted the words "He is arriv'de".

But why should such an insertion have been made at all? In the previous case which we considered there was a good reason in a bad inconsistency in the original text. Here the original would have been perfectly satisfactory as it stood. There is no reason for the reviser troubling to insert "He is arriv'de"; nor could we explain the addition as an attempt to supply material from the full play omitted by the reporter-versifier, for no such phrase occurs in $\mathrm{Q}_{2}$ or $\mathrm{Fr}_{\mathrm{I}}$. I am going to suggest that the instruction "obserue the king" is the reviser's interpolation, and that he had a good motive for making it, a motive not dissimilar to that in the previous case.

As it stands in the printed text the phrase " $\mathrm{He}$ is arriv'de" is a bald statement of fact: it is a "principal" clause. And as such it is tautological, for in the very first 
line of the scene Horatio has said "Madame, your sonne is safe arriv'de in Denmarke". I think it fairly obvious that "He is arriv'de" was intended as a "noun" clause, and that the sense of the passage was "I think that by this time the news that he has arrived has reached the court". The only obstacle to this interpretation is provided by the colon at the end of line 23 , but it is significant that the immediately preceding line also ends with a colon:

Madam, neuer make doubt of that:

I thinke by this the news be come to court:

$\mathrm{He}$ is arriv'de, etc.

One of the commonest types of printing-house corruption is the setting-up of, for example, the initial word of a line both in its proper place and also at the beginning of the next line. The compositor's eye catches the same thing twice. It is quite possible that here the compositor carelessly set up both in its proper place and at the end of the following line the colon which rightly occurs after "that".

In the next place we find that according to the printed text Horatio exhorts the Queen to observe her husband and says that if she does so she will discover that his plans for getting rid of Hamlet have miscarried, that "things fell not to his minde". His mind can only be the King's, and the phrase can only refer to the projected outcome of Hamlet's journey to England. Things had fallen out very much to Hamlet's mind.

Now why should Horatio tell Gertrude that by such observation she will discover that Claudius's plan had gone awry when he has just told her that fact? ${ }^{\text {I }}$ He has explicitly informed her that Hamlet has been "betray'd to death" in the King's "packet", that he has "escap't the danger/And subtle treason that the king had plotted", and that he is "safe arriv'de in Denmarke". The Queen has

I Cf. Gustav Tanger, Transactions of the Nerw Shakspere Society, r880-2, Part I, p. 188 . 
already commented on these facts; she knows that the King's plan has failed. Why then tell her that if she observes his conduct she will discover what she already knows? Surely the whole point of the passage was originally meant to be that, the news of Hamlet's return having reached the court, the King is very soon going to suffer the shock of realizing that his desperate plan for self-preservation has gone wrong and that he is once more in a position of danger. It is the fact that "the news be come to court/ $\mathrm{He}$ is arriv'de" that is going to make Claudius "quickely finde,/Hamlet being here, things fell not to his minde". The two parts of the passage are related as cause and effect. This suggestion receives support from two sources: (I) In examining QI vi $\mathrm{I}-\mathrm{I} 8$ and viii we found in the reporterversifier a tendency to repeat words and phrases in these different scenes the subjects of which are the same. Similarly the passage which we are examining echoes words from the first speech in scene xiii. What I am suggesting as the original purport of Horatio's remark in xiv 24-6 is an ironic sequel to xiii $\mathrm{I}-4$, doubtless intended as such by our reporter turned versifier: in that earlier passage the King says:

Hamlet is ship't for England, fare him well,

I hope to heare good newes from thence ere long,

If euery thing fall out to our content,

As I doe make no doubt but so it shall.

Here the King hopes to hear "good newes"; the "news" that have "come to court" by scene xiv are bad from his point of view. The King thinks that "euery thing" will "fall out to our content"; but according to Horatio he will find that "things fell not to his minde". (2) In Der Bestrafte Brudermord, v ii, Hamlet describes his voyage to Horatio. He concludes with the grim remark "Meine Ankunft aber wird dem Könige nicht angenehm seyn". Whatever view we take of the exact relationship between 
the German text and that of QI, it is obvious that they are in some way connected-whether the former is derived in whole or in part from the latter (as Tanger thought), or whether the two are in whole or in part founded upon a common original. ${ }^{\mathbf{I}}$ And this sentence from the Brudermord is to much the same effect as our suggested restoration of the original sense of Horatio's remark in QI scene xiv. ${ }^{2}$

If all this be accepted, it might be suggested that what the $Q_{I}$ reporter-versifier originally wrote in the passage with which we are concerned was as follows:

I thinke by this the news be come to court

$\mathrm{He}$ is arriv'de(;) the king shall quickely finde,

Hamlet being here, things fell not to his minde.

It would follow that the interpolator inserted "obserue" before "the king" and "and you" after. But once again, why should he go to the trouble of doing this? There is no motive discoverable. As it stood on this hypothesis the original was perfectly intelligible. Its very coherence militates against the probability of its being a correct restoration.

I want to suggest that the words "obserue the king" were interpolated after the composition of the original stratum of the text of scene xiv: and if my reconstruction of the original sense of the passage is right, it follows that in that original stratum the reporter-versifier had written "he", not "you", as the subject of the verb "shall finde". I submit that the original text was as follows:

I thinke by this the news be come to court $\mathrm{He}$ is arriv'de, and he shall quickely finde, Hamlet being here, things fell not to his minde.

1 The problem of Der Bestrafte Brudermord and its relationship to the other texts will concern us in chapter viII.

2 This remark, in the altered form in which we are taking it, is aptly followed in the next scene by the King's first thunderstruck words "Hamlet from England! is it possible?" ( $\mathrm{Q}$ xV I). 
And corroboration is to be found in the text of scene xiv itself.

The sequence of pronouns is extremely faulty. The first "he" refers to Hamlet; the second "he", and also "his", refer to the King. Now only a few lines earlier in scene xiv we find a passage which exhibits exactly the same misuse of pronouns:

(Hor.) He will relate the circumstance at full.

2ueene. Then I perceiue there's treason in his lookes

ro

That seem'd to sugar o're his villanie:

But I will soothe and please him for a time,

For murderous mindes are alwayes jealous,

But know not you Horatio where he is?

"He" in line 9 is Hamlet: "his" in lines IO and I I and "him" in line I2 refer to the King: and "he" in line I4 is Hamlet again. The meaning is quite clear, but the sequence of pronouns objectionable.

Again, consider what immediately follows the passage with which we have been dealing:

Things fell not to his minde.

Hor. He being set ashore, they went for England, And in the Packet there writ downe that doome To be perform'd on them poynted for him:... 30 "His" in line 26 refers to the King, but "he" in line 28 is Hamlet: and the unexpressed subject of the verb "writ" is not the immediately preceding pronoun "they" but Hamlet. Just as "he" in line 28 leaps over "his" in line 26 and refers to "Hamlet" in line 25, so the subject of "writ" is not "they" in line 28 but, leaping over that, the "he" at the beginning of line 28 .

We have discovered the misuse of personal pronouns in two passages in this scene where conditions of metre and line-division are perfect, and where consequently there 
can be no suspicion of interference by the interpolating reviser. It appears, then, that in reconstructing the reporter-versifier's original text in lines $23-6$ we have actually produced a version which exemplifies a technical flaw found elsewhere in the same scene in the same versifier's original text. This is a mark in favour of our reconstruction.

I have, then, advanced the hypothesis that the text of QI xiv 23-6 is composite, that the original stratum read as follows:

I thinke by this the news be come to court $\mathrm{He}$ is arriv'de, and he shall quickely finde,

Hamlet being here, things fell not to his minde,

and that a reviser inserted "obserue the king" (an interpolation) and changed "he" to "you" in line 24 (an emendation).

If it were pointed out that this hypothetical original is far worse than the other examples cited of the abuse of pronouns, I should agree, and claim that this extreme awkwardness was precisely the reason for the reviser's interference. In the case of the previous interpolation which we considered in this scene we found a motive for the reviser's pains; here there is an equally good motive. Some faults of pronominal sequence he could and did pass, but not such a bad one as this. Just as we rejected two possible conjectures of original readings here on the ground that they would be so good as to present no reason for a reviser's tinkering, so we may accept the present one because it gives an excellent reason for it. Our reconstruction has therefore these two merits-it involves a technical defect found in other portions of the same stratum of the text of the scene, and that defect (exemplified to extremity) constitutes a motive for alteration on the part of the reviser. No other hypothetical reading for the original can be found which fulfils these conditions.

As in the previous case, we can detect the sources of the 
wording of the interpolation. The reviser seems to have thought that the reporter-versifier had perpetrated a blunder as well as a syntactical howler, but in his alteration he did not take into account the full context of the offending passage. Instead of realizing the point, viz. that the news of Hamlet's return would reveal to the King the failure of his project, he decided that it should be the Queen who should make this discovery by observation of the King's behaviour after receiving the message. As we have noted, this produces inconsistency in the scene, but it is the situation envisaged by the reviser. Now there is an exactly similar situation to this at a previous, very important, point in the play. The whole object of the planning of the playscene is that Hamlet and Horatio, by observing the King's reaction, will discover his guilt in the successful murder of the late King. Here in scene xiv, in the final version, the Queen, likewise by observation of the King's conduct, is to discover his guilt in the projected murder of Hamlet himself. Moreover, at two previous points in the genuine Shakespearian texts we find phraseology from which unquestionably the wording of the interpolation-"obserue the king" - is memorially derived: and at both points Hamlet is speaking of the planning of the play-within-theplay. In II ii $598 \mathrm{ff}$. he says, in soliloquy:

I'll have these players

Play something like the murder of my father

Before mine uncle, I'll observe his looks,

I'll tent him to the quick, if a' do blench

I know my course.

And in IIr ii $73 \mathrm{ff}$. he says to Horatio:

There is a play tonight before the king, One scene of it comes near the circumstance Which I have told thee of my father's death. I prithee when thou seest that act afoot, Even with the very comment of thy soul Observe my uncle. 
In the first passage Hamlet is exhorting himself to do what in the second he instructs Horatio to do. The words run parallel, thus:

\section{II ii $598 \mathrm{ff}$.}

I'll have these players play... before mine uncle

something like the murder of my father

I'll observe his looks
III ii $73 \mathrm{ff}$.

There is a play tonight before the king

One scene of it comes near the circumstance/Which I have told thee of my father's death

I prithee when thou seest that act afoot. . observe my uncle

Such parallel phraseology used in connection with the same dramatic situation might easily cause confusion of the two passages in the memory. In particular we may notice that Hamlet refers to Claudius indifferently as "the king" or "my (mine) uncle". Within the later of the two passages we have the variation "before the king" and "observe my uncle": and between the two passages there is the variation "before mine uncle" and "before the king", where the identical initial word would assist in promoting confusion in a reporter's mind. In both passages the word "observe" occurs, and in the latter we have "observe my uncle". In view of the probability of confusion between the two passages, ${ }^{\mathrm{I}}$ and particularly the confusion between "the king" and "my uncle", this could with the greatest of ease have been transmuted in the interpolator's mind to "observe the king", the phrase which in my belief he inserted in scene xiv.

In the case of the other interpolation with which we

I Such a confusion actually occurs in $Q_{\mathrm{I}}$ ix 60, where Hamlet says to Horatio "doe but obserue his lookes". This directly corresponds to III ii 78 , "Observe my uncle", which has, however, been confused with II ii 600 , "I'll observe his looks". 
dealt we found that part of its phrasing was suggested by words in the original stratum itself. The present case is not dissimilar in this. The Queen's first speech in scene xiv begins

Then I perceiue there's treason in his lookes...

(i.e. Claudius's looks). Perhaps this was enough to remind the reviser of the situation in the play-scene where the King's looks were all-important, and to suggest to him that later in scene xiv a similar situation should be delineated, a situation turning on observation of Claudius's looks. In particular we remember the phrase "I'll observe his looks" in II ii 600. "His lookes" in QI xiv ro seems to have constituted a link in the interpolator's mind with the planning of the play-within-the-play, whence by the processes described he evolved the words of his addition. ${ }^{\mathrm{I}}$ He altered the "he" of the earlier stratum of xiv 24 to "you" because that was the source of his dissatisfaction with the construction of the original, and because in one of the Shakespearian passages present at the back of his mind (III ii $73 \mathrm{ff}$.) Hamlet had exhorted Horatio to observation so that he, the observer, should make a certain discovery. Once the insertion had been made, the emendation had to follow in order to make the sense of the passage conform with it.

As for the manner in which the insertion was made in the manuscript, the reviser probably wrote the phrase "obserue the king" above the original line, indicating exactly where it was to be inserted, thus:

$$
\begin{aligned}
& \text { obserue the king } \\
& \text { He is arriv'de, Land the shall quickely finde, } \\
& \text { Hamlet being here, things fell not to his minde. }
\end{aligned}
$$

I Probably the reporter-versifier had derived "his lookes" (xiv ro) from II ii 600 . If so, it would appear on our hypothesis that these words led the interpolator back to their source in the full play and to another passage closely connected with it. 
The compositor was therefore faced with what was apparently a single line too long to set up as such, and resorted to line-division of his own.

There is more to be said elsewhere about this scene peculiar to QI. Meanwhile we may assemble the conclusions which concern us here. (I) There are two strata of text: the first, comprising the bulk of the scene, was written in metrical verse, doubtless the work of the reporter-versifier whose complicity in the production of the QI text was demonstrated in chapter IV. He was prone to leave inconsistency in his version, and also to misuse personal pronouns. The other stratum consists of two small interpolations, one of which involved a slight alteration of the original: these additions, made without regard to metrical propriety, forced the compositor to disrupt the line-division of the earlier stratum in their neighbourhood, in the manner described. (2) The two interpolations are similar in the following respects: (i) both were made to cover up glaring errors in the original stratum, in one case an inconsistency, in the other a syntactical blunder; (ii) both were made without assistance from any document; (iii) in both cases the phrasing was partially suggested by words in other parts of the original stratum of this same scene; (iv) in both cases the interpolator was indebted to his recollection of other passages earlier in the play.

\section{II}

\section{(Scene vi)}

I have argued for the existence of an interpolating reviser who attempted to remove certain absurdities from a scene in QI not directly related to anything in the authentic Shakespearian texts. There are other passages in QI where to my view his handiwork is also visible, passages which are directly related to material in $Q_{2}$ and $F_{1}$. Here another motive appears for the reviser's activity, viz. his recollection 
of matter from the full play which had been omitted by the person or persons primarily responsible for the QI text. It happens that in certain places where he amplified the original which he was revising he failed to join his insertion neatly to the earlier stratum, so that actual textual dislocation in QI gives him away.

A good example of such dislocation occurs in scene vi lines 95-106, where QI reads as follows:

(Cor.) And if this be not true, take this from this.

King. Thinke you t'is so?

95

Cor. How? so my Lord, I would very faine know

That thing that I haue saide t'is so, positiuely,

And it hath fallen out otherwise.

Nay, if circumstances leade me on,

100

Ile finde it out, if it were hid

As deepe as the centre of the earth.

King. how should wee trie this same?

Cor. Mary my good lord thus,

The Princes walke is here in the galery,

There let Ofelia, walke vntill hee comes:...

This passage is a fairly close approximation to Ir ii $15 \mathrm{I}-62$ in the accredited texts, and it is not of its metrical deficiencies that I wish to speak. For in straining to reproduce Shakespearian passages the QI reporter often loses all sense of structure: his attention is concentrated upon a desperate effort of the memory. This is not a passage where the reporter-versifier has launched out independently, and where accurate metre might reasonably have been looked for. What I wish to stress as significant is two small peculiarities in the passage - the question-mark after "How" in line 97 , and the small initial letter at the beginning of line 103 .

There can be no doubt that after the King has said hesitantly "Thinke you t'is so?" Corambis's quick indignant rejoinder is meant to run "How 'so', my Lord?" Did the compositor simply misplace a question-mark? We 
cannot say that it is impossible that he should have done so, but it is certainly a remarkable error-he has heavily separated two obviously connected words. And a close examination of the passage suggests a more credible explanation. I would associate the two irregularities - the misplaced question-mark and the line which begins with a small letter. I believe that here also the copy before the compositor was composite, and that the original stratum read as follows:

(Cor.) And if this be not true, take this from this.

King. Thinke you t'is so? how should wee trie this same?

Cor. How? Mary my good lord thus,

The Princes walke is here in the galery,...

Here the isolated interrogative ejaculation "How?" has real point, and the sequence is perfect. Through the clumsiness of the interpolating reviser of the reporter's manuscript, this word is in QI not only separated from the line which gives it point, but actually precedes it by six lines. I would suggest the following reconstruction of the copy for QI at this point: ${ }^{I}$

King. thinke you t'is so? King. how should wee trie this same?

Cor. how? nay, if circumstances leade me on,

so my Lord, I would very faine know

that thing that I have saide $t$ 'is so, positively, and it hath fallen out otherwise. Ile finde it out, if it were hid as deepe as the centre of the earth.

Cor. mary my good lord thus,

the Princes walke is here in the galery, etc.

In changing the simple "how?" into the connected phrase "how so" the interpolator forgot to delete the question-

$x$ The diagram is put forward simply as an illustration of what the manuscript may have looked like at this point: it would certainly have been more cramped and less tidy. It is also possible to produce 
mark, which the compositor, faithful to his copy, reproduced. A further tentative suggestion may be made. Copy of this sort may well have given the compositor some difficulty. As he saw it in the manuscript itself, Claudius's second question formed the latter half of a line; he reproduced the transference indicated by the interpolator, but in straining to do so he momentarily forgot that the question now required the initial capital which he would normally have supplied at the beginning of a line. If this last point is tenuous, I would nevertheless say that the "How?" reads so very naturally in our reconstruction of the original stratum of text, that we may consider it in the last resort sufficiently likely. It explains the question-mark much better than the simple assumption that it is an extraordinary compositorial error.

The motive for the reviser's interference was the desire to supply material from the full play which the writer of the original stratum had omitted. The whole passage runs as follows in the authentic text:

King.

Do you think 'tis this?

I

2ueen. It may be, very like.

Pol. Hath there been such a time, I would fain know that, That I have positively said "Tis so", When it proved otherwise?

King. Not that I know.

Pol. Take this from this, if this be otherwise;

If circumstances lead me, I will find

Where truth is hid, though it were hid indeed Within the Centre.

King. How may we try it further?

Pol. You know sometimes he walks four hours together Io Here in the lobby....

(II ii I 5 I ff.)

other diagrams which, if representing the $Q_{\mathrm{r}}$ manuscript, would have resulted in the same conditions in the printed text. But the reasons for the separation of "how should wee trie this same?" and the rejoinder "how?" would necessarily be the same as indicated here. 
Of this passage, the reporter responsible for the earlier stratum of the QI text remembered, and imperfectly reproduced, lines I, 6, 9 (the second half), and IO-II: he also remembered the words "'tis so", which he substituted for "'tis this" in the first line. The interpolating reviser recollected a good deal more of the passage in the full play, and inserted it in the manner described.

There is at least one other passage in the neighbourhood of this one where I suspect the hand of the reviser; but it will be convenient to mention it at the end of the next section.

\section{III}

(Scene ix \& scene vi)

As soon as the court has assembled for the Gonzago play the following conversation takes place between the King and Hamlet in QI :

(a play?

King. How now son Hamlet, how fare you, shall we haue

Ham. Y faith the Camelions dish, not capon cramm'd, feede a the ayre.

I father: My lord, you playd in the Vniuersitie.

(ix 69-72)

With this compare III ii 90-6 in the authentic texts.

The person responsible for reporting Hamlet's quibble in QI has understood it only partially. He realizes that the chameleon's dish is the air, but he does not remember that Hamlet refers to the King's empty promises-in the full texts he says "I eat the air, promise-crammed". A vague recollection of this and of the words "you cannot .feed capons so" results in the nonsensical conflation "not capon cramm'd", while "feede" is substituted for "eat". In QI the writer fails to grasp that Hamlet talks of himself as the capon which the King should be fattening against its destruction. That such a complex quibble should be but imperfectly appreciated by a memorial reconstructor is easy 
to understand: in "bad" Quartos we continually find reporters missing the point of a pun or joke. Here, however, despite these misunderstandings, one thing is fully understood - the genesis of the quibble in the King's use of the formula "how fare you?". This is highly interesting in the light of what follows.

In the QI passage comment is aroused by three separate facts, which singly might well seem insignificant, but which taken together seem to me to point directly to a certain conclusion. First: the King asks Hamlet two questions, one immediately after the other; Hamlet answers these in order, and the structure of the passage is consequently extremely clumsy - the first answer is separated from the relevant question by the second question, and the second answer is separated from the relevant question by the first answer. Thus the quibble is separated from the phrase which gives rise to it and which gives it point, so that the quickness of the repartee is lost: and after the complex witticism, which would fully occupy the attention of audience or reader, Hamlet baldly says "ay, father", by which time the query he is answering is probably forgotten. We might not regard all this as beyond the incompetence of a reporter, but it must be considered along with the second fact, which is that Hamlet's reply to the King's second question, "I father", begins a line right at the margin, while his quibbling reply to the first question ends the preceding line only a short space from the margin. The whole passage appears to be prose: why then do the words "I father" not follow in the same line as "feede a the ayre"? If it be argued that this might simply be an artifice to soften the abruptness of the transition to the eye, though it could not do so to the ear, I should still suggest that a better explanation is forthcoming if the point is considered in relation to the first one. The third fact is that if the words "how fare you" are excised from the first line the result is a metrically regular pentameter. This might be 
regarded as fortuitous, but it is the third link in a chain of circumstantial evidence which in my opinion warrants the hypothesis of composite copy once again.

I suggest that the quibble, and also the phrase "how fare you" which evokes it, constitute an interpolation, and that the original stratum ran:

King. How now son Hamlet, shall we have a play?

Ham. I father: My lord, you playd in the Vniuersitie. etc.

Again the interpolator's motive was to supply material from the full text which had been omitted by the original reporter. The quibble was probably an interlinear insertion; since it was too long for a single line, the reviser had to finish it with four words occupying a line by themselves. "How fare you" was doubtless inserted above the first line, between that and the preceding stage-direction, with a mark to show where it was to be fitted in. The manuscript may be reconstructed thus:

enter King, Queene, Corambis, and other Lords. how fare you,

King. how now son $\mathrm{Hamlet}, L$ shall we have a play? yfaith the Camelions dish, not capon cramm'd, feede a the ayre.
Ham. I father: My lord, you playd in the Universitie.
etc.

A passage which has one characteristic similar to this occurs in QI vi 77-82; Corambis finishes reading out Hamlet's letter to Ofelia:

Thine euer the most vnhappy Prince Hamlet.

My Lord, what doe you thinke of me?

I, or what might you thinke when I sawe this?

$K$ ing. As of a true friend and a most louing subiect.

Cor. I would be glad to prooue so.

Now when I saw this letter, thus I bespake my maiden :. . . 
Of the two successive questions put by Corambis the King answers only the first: the second is disregarded altogether. That the latter is a rhetorical question does not in the least diminish the awkwardness of the sequence. The King's answer is closely bound to Corambis's first question by its corresponding structure just as in the "good" texts where there is no interruption:

Pol. What do you think of me?

King. As of a man faithful and honourable. (II ii r 29-30)

:erial ginal tion; id to lves. line, th a cript I suggest that the line " $I$, or what might you thinke when I sawe this?" is an interpolation, and that the sequence of the original stratum was good.

That in the case of the "Camelions dish" insertion the interpolator was working from memory is sufficiently clearly indicated by the garbling. There are no less positive indications that he was working from memory here also, and further that, as in other passages with which we have dealt, his phraseology was influenced by that of the original stratum. In vi 82 the original reporter had written "Now when I saw this letter". This reminded the interpolator of the following passage in the full play:

(Pol.)

But what might you think

When I had seen this hot love on the wing,

As I perceived it (I must tell you that)

Before my daughter told me?

(II ii I $3 \mathrm{I}-4$ )

this out

His recollection stopped at the word "this", which, influenced by QI vi 82 , he applied to the letter; influenced by the same line he substituted "sawe" for "had seen" in the authentic version. We may note finally that in making the interpolation he linked it to what went before by beginning " $\mathrm{I}$, or..." " he did not however link it to what followed, and the tell-tale wrench remains. 


\section{IV}

(Scene vi \& scene ii)

It is mainly upon the passages treated in the foregoing sections that I would rest the case for the existence of a reviser responsible for interpolations in the original textbasis of QI. This hypothesis seems to me to be called for by the condition of the printed text at these points. But I should add that nowhere does that call appear to me more imperative than in a passage cited by Professor Dover Wilson, ${ }^{\mathbf{x}}$ viz. Ophelia's first speech to Hamlet in the "nunnery" scene:

My Lord, I haue sought opportunitie, which now I haue, to redeliuer to your worthy handes, a small remembrance, such tokens which I haue receiued of you.

(QI vi I40-2)

Embedded in this are three metrical pentameters:

My Lord, I haue sought opportunitie,

To redeliuer to your worthy handes

Such tokens which I haue receiued of you.

I have not the slightest doubt that this passage of verse, intended as such, originally stood in the text behind QI. According to Professor Dover Wilson's hypothesis, it was regarded as "a piece of 'ur-Hamlet' verse"; according to our hypothesis, it is the work of the reporter-versifier. The interpolator has added two phrases, destroying the metrical structure of his original.

I would finally consider a passage of which I can only say that I have suspicions. I would certainly not use it as a positive indication of composite copy behind $\mathrm{Q}_{\mathrm{I}}$ : but that hypothesis, based on other evidence, suggests what seems to me the best explanation in this case also.

At I ii 2I4-20 of the authentic Shakespearian texts, where Horatio and his fellow-watchers are describing to

I The Library, 1918, p. 235. 
Hamlet the appearance of the Ghost, we have the following passage:

Ham. Did you not speak to it?

Hor.

My lord, I did,

But answer made it none, yet once methought

It lifted up its head, and did address

Itself to motion like as it would speak:

But even then the morning cock crew loud,

And at the sound it shrunk in haste away

And vanished from our sight.

Ham.

'Tis very strange.

The corresponding passage in QI runs thus (ii $\mathrm{I}_{3}{ }^{8-45}$ ):

Ham. Did you not speake to it?

Hor. My Lord we did, but answere made it none,

Yet once me thought it was about to speake,

And lifted vp his head to motion,

Like as he would speake, but euen then

The morning cocke crew lowd, and in all haste,

It shruncke in haste away, and vanished

Our sight.

Ham. Indeed, indeed sirs, but this troubles me: etc.

Three irregularities coincide in this passage: (i) the double repetition - "it was about to speake" and "like as he would speake", and "in all haste" and "in haste"; (ii) the structural clumsiness of Horatio's speech, with the last two words awkwardly pushed into a line by themselves; (iii) the odd mixture of masculine and neuter pronouns in reference to the Ghost.

Now not one of these irregularities is beyond the power of a single reporter. Defective structure is only too common in QI, and in the other "bad" texts. In the full Shakespearian versions the Ghost is referred to as both "he" and "it", though not in this confused fashion, each pronoun always being used with a subtle underlying purpose: but we should not be surprised to find a reporter failing to 
appreciate this. Again, there are at least two lines elsewhere in QI which embody repetitions equally absurd:

and

Shee as my childe obediently obey'd me.

An eye, at which his foes did tremble at.

But even so, I cannot help feeling that in the passage with which we are concerned the double repetition within as few as five lines is significant, especially when taken in conjunction with the metrical irregularity: for in the two lines just quoted the repetitions are undoubtedly the result of a painful striving after metrical regularity which is achieved by their aid: this is not true of our passage.

I would hazard the conjecture that here again composite copy underlies the QI text, and that the original layer read as follows:

Ham. Did you not speake to it?

Hor. My Lord we did, but answere made it none,

Yet once me thought it was about to speake,

But euen then the morning cocke crew lowd,

And in all haste it vanished our sight.

Ham. Indeed, indeed sirs, but this troubles me: etc.

The interpolator again remembered more of Shakespeare's words than did the writer of the earlier stratum. He inserted this material without troubling to accommodate it properly to the text which he already had before him (hence the repetitions) and without care for metrical consistency. The manuscript which came into the compositor's hands probably looked something like this:

my Lord we did, but answere made it none,

yet once me thought it was about to speake,

like as he would speake, but even then the morning cocke crew lowd, shruncke in haste away, and and in all haste, it $\lambda$ vanished our sight. 
Here the words "like...lowd" appear to constitute a single line, far too long to be set up as such. As in previous cases which we have considered, I believe that the compositor began with "like" and counted out a pentameter, and so on until he was left with two extra words which he was forced to put into a line by themselves.

Mainly from a vague recollection of the Shakespearian "like as it would speak" the writer of the first stratum produced "it was about to speake", and in his hands the Shakespearian "in haste" became glorified into "in all haste". The interpolator remembered these two Shakespearian phrases almost accurately ${ }^{\mathrm{I}}$ - with only one word varied-and inserted them (with other material), omitting to notice, or at any rate unperturbed by, the extraordinary double repetition thereby brought about, just as he was unconcerned by the metrical fault he was causing. And as the coping-stone of the argument it is interesting to note that in the above reconstruction of the QI manuscript the Ghost is referred to as "it" by the writer of the first stratum and as "he" by the writer of the second. Thus everything falls neatly into place.

In conclusion I would say that the passages discussed in re's this chapter are not put forward as the only instances of the interpolator's work in the QI text: they are simply given as what appear to me the clearest examples. There are other places where I think he may have been involved; and it is even possible that he may on occasion have inserted material sufficiently carefully to avoid the textual dislocation which would have given him away.

$$
\text { POSTSCRIPT }{ }^{2}
$$

In chapter v I expressed agreement with Signor Ramello, suggesting that the "actor-reporter" and the "reporter-

"He remembered "in haste" exactly in its context ("it shrunk in haste away").

2 Written after Dr Greg had sent me his Foreword. 
versifier" may very well have been the same person. We may for the sake of convenience refer to this agent simply as the reporter. Now in this chapter I have argued for the existence of both this reporter and an interpolator. I am perfectly prepared to admit, however, that here too we have to do with a single agent - that the reporter revised portions of his own work, making insertions in what he had already written without troubling to work these in very carefully. This view is supported by the fact that the insertions are made up of recollected material in the same manner as the rest of the text. ${ }^{I}$ The main point which I wish to make in this chapter is that there are insertions: these may have been made by a second hand or by the reporter himself, correcting and amplifying his own handiwork. I am quite ready to accept this latter view. In his Foreword Dr Greg says "That there has been revision in the way of afterthoughts may be conceded". Should this be granted, I would press my case no further.

I I have claimed as an interpolation the words "obserue the king" in QI xiv 24. The source of the word "obserue" is probably III ii 78 in the authentic texts. It also occurs in II ii 600 in the phrase "I'll observe his looks" and the words "his looks" are found in QI xiv ro, which is not an interpolation. This suggests single identity for reporter and interpolator $-a$ much less cumbersome explanation than that which I suggested when working on the theory of two separate agents. 
WHAT STAGE OF THE HAMLET TEXTHISTORY UNDERLIES QI?

I have said that behind the reported text of QI there lies a version of the play either identical with or at least extremely close to that given in $\mathrm{Q} 2{ }^{\mathrm{I}}{ }^{\mathrm{I}}$ We must now attempt to discover which of these alternatives is the correct one, reviewing in some detail the arguments which have been advanced in support of the proposition that the QI text represents a version of the play distinct from those of $\mathrm{Q}_{2}$ and FI. It must be borne in mind throughout that the Q $I$ text is a memorial reconstruction, and that the reporter was able to use his invention when his memory failed. This has an important bearing on the subjects with which we are concerned in the present chapter, as has also the fact that in an actor's reconstruction confusion between entirely different plays is not only possible but likely.

\section{THE KYD QUOTATIONS IN QI}

Several close parallels between passages in QI Hamlet and passages in the works of $\mathrm{Kyd}$ have been pointed out by Widgery, Sarrazin, Boas, and Robertson. ${ }^{2}$ These are as follows:

I. QI Leartes. And remember well what I haue said to you. exit. Ofelia. It is already lock't within my hart,...

(iii 43-5)

I See p. I33.

2 See Widgery, Harness Prize Essay (1880); Sarrazin, Thomas Kyd und sein Kreis (1892), pp. 94-122; Boas, Works of Kyd (1901), pp. xlv-liv; Robertson, The Problem of "Hamlet" (rgrg), pp. 33-4r. 
Cf. Ist Part of Feronymo: ${ }^{1}$

Bellimperia. Farewell, my lord,

Be mindful of my love and of your word.

Andrea. 'Tis fixed upon my heart.

(Dodsley's Old Plays, and ed. iii 70)

2. Qr (Leartes.) Reuenge it is must yeeld this heart releefe,

For woe begets woe, and griefe hangs on griefe.

Cf. Spanish Tragedy:

(xv 54-5)

Isabella. O where's the author of this endless woe?

Hieronimo. To know the author were some ease of grief,

For in revenge my heart would find relief.

(II $v 39$ ff.)

3. QI (2ueene.) I will conceale, consent, and doe my best,

What stratagem soe're thou shalt deuise.

Cf. Spanish Tragedy:

(xi $106-7$ )

Bellimperia. Hieronimo, I will consent, conceal, And aught that may effect for thine avail, Join with thee to revenge Horatio's death.

Hieronimo. On, then; and whatsoever I devise,

Let me entreat you, grace my practices.

(Iv i $46 \mathrm{ff}$ )

4. QI (Leartes.) Therefore I will not drowne thee in my teares,... .

Cf. Spanish Tragedy:

To drown thee with an ocean of my tears.

(II $v$ 23)

5. QI (King.) He might be once tasked for to try your cunning.

Cf. Spanish Tragedy:

(xv 13 )

You mean to try my cunning, then, Hieronimo?

(Iv i 178 )

I This play is not itself by Kyd, but may possibly be founded upon a play by him; see Boas, op. cit. pp. xxxix-xliv and Robertson, op. cit. p. 34 note 2 , and pp. 53 ff. 


\section{QI: KYD QUOTATIONS}

6. QI Leartes. And how for this?

King. Mary Leartes thus:... .

Leartes. T'is excellent,... .

$(\mathrm{xv}$ I $4-15,37)$

Cf. Spanish Tragedy:

Lorenzo. And how for that?

Hieronimo. Marry, my good Lord, thus....

Lorenzo. O excellent....

(Iv i 74, I 26)

7. QI Hamlet. And if the king like not the tragedy,

Why then belike he likes it not perdy. (ix I 85-6)

Cf. Spanish Tragedy:

Hieronimo. And if the world like not this Tragedy,

Hard is the hap of old Hieronimo.

(Iv i r 96-7)

8. QI (Hamlet.) I neuer gave you cause.

(xvi I 64)

Cf. Spanish Tragedy:

Lorenzo. Hieronimo, I never gave you cause.

(III xiv I48)

9. QI King. ...wee'l have Leartes, and our sonne,

Made friends and Louers, as befittes them both,... .

Cf. Spanish Tragedy:

(xvii 8-9)

ff.)

Castile. But here, before Prince Balthasar and me, Embrace each other, and be perfect friends. ${ }^{I}$

(III xiv I 54)

ı. QI Leartes. You haue preuail'd my Lord, a while I'le striue, To bury griefe within a tombe of wrath,...

Cf. Spanish Tragedy:

(xiii I 22-3)

Bellimperia. Thou hast prevailed; I'll conquer my misdoubt,

And in thy love and counsel drown my fear.

(II iv 20)

I Boas points out the similarity of situation here, and the fact that in both cases the reconciliation is the prelude to the catastrophe. 
I I. QI (Player-Duke.) Thou maist (perchance) haue a more noble mate, ...

(ix I I I)

Cf. Spanish Tragedy:

Ay, but perhaps she hopes some nobler mate. (II i 26)

Boas notes also a few more general similarities: (i) the similarity between the dialogue of the Duke and Duchess on the subject of second marriage in the play-within-theplay in Qr and Cornelia's self-reproaches for having taken a second husband (Cornelia, II, 3I-54); (ii) that between the King's moralizings to Hamlet on the loss of fathers as a general law of nature in Qr scene ii and Cicero's similar reflections addressed to Cornelia (Cornelia, II, 2I4-16, 252-7); (iii) that between the King's outburst in the $\mathrm{Q}_{\mathrm{I}}$ prayer-scene:

The earth doth still crie out vpon my fact,

Pay me the murder of a brother and a king...

(x 4-5)

and The Murder of Fohn Brewen: "Albeit there was none in the world to accuse Caine for so fowle a fact... yet the blood of the iust Abel cried most shrill in the eares of the righteous God for vengeance, and reuenge on the murderer" (ed. Boas, p. 287).

A few of these parallels are so vague that we may wonder whether anything is gained by citing them: and in Boas's own words "Elizabethan writers were fond of ringing the changes on a stock of current phrases, and... verbal coincidences here and there may be purely accidental". B But admittedly some of the parallels are extraordinarily close. It is this very closeness which is the strongest argument against the interpretation put upon them by Boas and Robertson. "The series of parallels quoted", says Boas, "point to the survival in the First Quarto of traces of Kyd's play", i.e. the Ur-Hamlet. Robertson is even more emphatic: ${ }^{3}$

${ }^{1}$ Op. cit. p. liii. $\quad=$ Ibid. $\quad{ }^{3}$ Op. cit. p. 4 r. 
To refuse to see in this string of verbal coincidences a proof of the survival of portions of Kyd's original text in Hamlet is to evade phenomena which can be explained in no other way.... If we are to suppose Shakespeare... composing a play of his own, we conceive him as parroting in the weakest way... his contemporaries who were incomparably his inferiors in literary power. A tag or a poetic trope he might and did echo from other poets, as they so constantly echoed each other; but here we have many phrases which are not current tags, and tropes not worth repeating. If Shakespeare penned them he was simply copying other men's humdrum dialogue, as if for lack of power to make his own independently. The conception only needs to be put clearly in order to be rejected. The young Shakespeare was not more but less likely than other men to plagiarize thus weakly and slothfully.

The passages from QI Hamlet quoted above cannot, Robertson thinks, be by Shakespeare; they are closely paralleled in $\mathrm{Kyd}$; and as "in the parts of our play under notice there is no question of the intervention of any other hand" the evidence suggests that we have to do with survivals from the alleged Kydian Hamlet. But there most certainly is another hand to be reckoned with - that of the reporter responsible for the QI text $-a$ hand which Robertson and Boas completely ignore. The very closeness of some of the parallels makes infinitely more probable the hypothesis that in the process of memorial reconstruction the reporter has confused similar situations in different plays of the same type. Either that, or he has deliberately borrowed from other plays in reconstructing Hamlet. There are passages in QI which similarly echo other Shakespearian plays. To give only one example, at iv $86 \mathrm{ff}$. we find the following:

Ghost. Reuenge his foule, and most vnnaturall murder:

Ham. Murder.

Ghost. Yea, murder in the highest degree,

As in the least tis bad,

But mine most foule, beastly, and vnnaturall. 
Embedded in this passage is an unmistakable (though inaccurate) echo of Richard III, v iii I96-7:

Perjury, perjury, in the highest degree;

Murder, stern murder, in the direst degree; ...

We need not suppose that Shakespeare here, and Kyd in the other cases, duplicated themselves in the extraordinary fashion implied by Boas and Robertson. These critics ignore the nature of the transmission of the QI text and the bearing of that upon the inference to be drawn from these close parallels between QI and plays by Kyd. ${ }^{\mathrm{I}}$ A memorial reconstructor, reproducing Hamlet as best he could, has, deliberately or involuntarily, borrowed passages from other plays altogether, often setting them down incorrectly since he had only his memory to aid $\operatorname{him}^{2}$

\section{HAMLET'S VOYAGE}

In support of the theory that $Q_{1}$ represents, or misrepresents, a Hamlet play anterior to that of $Q_{2}$, Widgery 3 pointed out that the description of Hamlet's voyage in

I See pp. 43-4.

2 Robertson quotes two parallels between Kyd's Soliman and Perseda and the full texts of Hamlet, where there are no corresponding lines in Qr :

Soliman and Perseda:

(i) Importing health and wealth of Soliman.

(ii) Fair locks resembling Phoebus' radiant beams, Smooth forehead, like the table of high Jove.

Hamlet:

(i) Importing Denmark's health and England's too.

(ii) Hyperion's curls, the front of Jove himself.

Robertson takes these two lines in Hamlet to be survivals from the Ur-Hamlet, omitted in Qr. But the parallels are quite general and do not in my opinion point to that conclusion at all. General similarities of diction are found in different writers throughout the Elizabethan period.

3 Harness Prize Essay (1880), p. I r 9. 
QI scene xiv contains a line not paralleled in the texts of $\mathrm{Q}_{2}$ and $\mathrm{F}_{\mathrm{I}}$ but present in Der Bestrafte Brudermord:

Being crossed by the contention of the windes,...

(Qr xiv 5)

Nun begab es sich, dass wir eines Tages contrairen Wind hatten,...

(Brudermord, $\mathrm{v}$ ii $\mathrm{I} 3$ )

There is no mention of unfavourable weather in the version of the genuine Shakespearian texts, and the tale of the fight with the pirates is absent from both Q $I$ and the Brudermord. But a close examination of all the versions of the story reveals as unacceptable a hypothesis so simple as that $Q_{1}$ here represents a version anterior in date to that of Q2. Let us then consider in turn each account of Hamlet's adventure-first, that of the Brudermord, then that of $\mathrm{Q}_{2}$ and $\mathrm{F}_{\mathrm{I}}$, and finally that of the "bad" Quarto.

In the German play we find the relevant events both represented (IV i) and later described in a scene ( $\mathrm{V}$ ii) between Hamlet and Horatio, as in $\mathrm{Q}_{2} \mathrm{v}$ ii, not between Horatio and the Queen, as in QI xiv. Thus, although $Q_{1}$ agrees with the Brudermord against $Q_{2}$ in mentioning contrary winds, the Brudermord agrees with $\mathrm{Q}_{2}$ against $Q_{I}$ in placing the narrative in a Hamlet-Horatio scene and QI is isolated. This last fact raises an extremely difficult problem; ${ }^{I}$ but we are concerned here only with the narrative itself. According to the Brudermord, Hamlet, accompanied by two ruffians, embarks for England; contrary winds force them to anchor by an island not far from Dover; Hamlet and his two escorts land on this island in order to enjoy the fresh air; Hamlet proposes that the three of them should have a meal, whereupon the two ruffians inform him that they have orders from the King to take his life; Hamlet pleads with them, but they do not heed; he attempts to seize a sword from one of them, but is prevented; one of the intended assassins says to his I See p. 27 i infra. 
fellow: "You fire from this side, I from the other." Hamlet now resorts to trickery; he asks to be permitted to pray: when he is ready to die, he will raise his hands: they are to shoot simultaneously. They agree to humour him; but when Hamlet raises his arms he falls forward, so that the two ruffians kill each other. Hamlet gives them the coup de grâce with their own swords, and then searches them and finds a letter from the King to an English hangman (Erzmörder), commanding that, should the first attempt on Hamlet's life have miscarried, he is to be put to death forthwith. Hamlet resolves to return to Denmark; but, fearing that the captain of the ship may likewise be treacherous, he decides not to go by sea, but to proceed to the first "Platz" and take post-horses, ordering the sailors back to Denmark- "Ich will den ersten Platz suchen", he says, "und die Post nehmen; den Schiffer will ich nach Dännemark wieder zurück commandieren" (IV i 80). This is on the whole a clear and coherent story, ${ }^{\mathrm{I}}$ quite independent of that in $\mathrm{Q}_{2}$ and FI.

In Shakespeare's play Hamlet, aboard the ship bound for England, finds that he cannot sleep. Suspicious of his escorts, Rosencrantz and Guildenstern, he goes up on deck where they are sleeping, feels their pockets, finds the "packet" which they are bearing from Claudius to the King of England, discovers Claudius's treachery, substitutes a new commission enjoining the execution of the bearers, and seals it with his father's signet which he has in his purse. Next day pirates attack the ship; during the fight Hamlet boards their vessel; just at that moment the

I In order to get to the nearest post-station Hamlet must, since he is on an island, travel by sea. Presumably, then, he means that he will dismiss the ship on arrival at the nearest point on the mainland. As his reason for deciding to return home by land is fear of treachery on the part of the captain, he must have had qualms about going even so far in the ship, especially as he would return to it without his two companions. In this particular the story in the Brudermord is defective; but this in no way affects the argument. 
pirates get clear of the Danish ship, so that Hamlet alone becomes their prisoner. They treat him well, obtaining from him an assurance that he will do them a good turn later. They set him ashore in Denmark, and he returns to the court. This is a completely coherent account of a story quite different from that in the Brudermord, except inasmuch as both versions have a written commission found by Hamlet in the possession of his treacherous attendants.

In striking contrast with these two versions, no coherent account at all can be constructed from the material supplied in QI scene xiv. Consider the content of that scene. Horatio begins:

Madame, your sonne is safe arriv'de in Denmarke,

This letter I euen now receiv'd of him,

Where as he writes how he escap't the danger,

And subtle treason that the king had plotted,

Being crossed by the contention of the windes,

$\mathrm{He}$ found the Packet sent to the king of England,

Wherein he saw himselfe betray'd to death,

As at his next conuersion with your grace,

$\mathrm{He}$ will relate the circumstance at full.

The Queen comments on the King's treachery, and declares that she will "soothe and please him for a time" because "murderous mindes are alwayes jealous". She asks Horatio where her son is, and he tells her that he has an appointment with him next morning "on the east side of the Cittie". The Queen asks him to tell Hamlet to be careful, and he reassures her. Then she asks what has become of Rosencrantz and Guildenstern, and Horatio tells her:

He being set ashore, they went for England, And in the Packet there writ downe that doome

To be perform'd on them poynted for him:

And by great chance he had his fathers Seale,

So all was done without discouerie.

Then the Queen takes her leave. 
All that QI tells us of Hamlet's adventures is that contrary winds beset the ship, that he found the packet with his own death-warrant in it, that he was set ashore, that he had altered the commission and sealed it with his father's signet, and that his companions went on to England to their death. This tale is riddled with gaps. We may pass over the impression conveyed by the text that the "contention of the windes" and the finding of the packet were connected in some way not indicated. But there are other difficulties. First, why was Hamlet "set ashore"? Apparently Rosencrantz and Guildenstern allow him to disembark, and proceed on their journey without him, although the reason why they were going to England at all was to escort Hamlet by the specific order of the King. Secondly, where was he set ashore? It is quite clear that the voyage had already started when the ship was "crossed by the contention of the windes"', ${ }^{1}$ and Hamlet must have been set ashore somewhere not in Denmark; furthermore, he must have found his way back to Denmark by himself, in some unspecified manner. ${ }^{2}$ Is it not clear that, in this, QI presupposes a story similar to, if not indeed identical with, that given in the Brudermord? From the version of the story underlying the German play the person who concocted the text of QI scene xiv has grasped two points - first, the fact that during the voyage the ship was impeded by the weather, ${ }^{3}$ second, the fact that sometime after the voyage had started Hamlet went ashore: and the Brudermord tells us where he went ashore-on an island near Dover. But in other respects QI agrees with the account given in $\mathrm{Q}_{2}$ and the Folio. Hamlet finds the

${ }^{1}$ Had the ship been prevented by a storm from leaving harbour at all Horatio would not have said that Hamlet was "safe arriv'de in Denmarke".

${ }^{2} Q_{I}$ is even more defective in this than the Brudermord.

3 In the Brudermord by contrary winds, in QI by "contention" of the winds, i.e. presumably a storm. Despite this slight difference the two are obviously related. 
packet while still on the ship, alters it to ensure the doom of his escorts, and avoids discovery of the substitution by using his father's seal. These details do not fit into the Brudermord story. ${ }^{\mathrm{I}}$

It appears, therefore, that whoever constructed the text of QI scene xiv trumped up an incomplete and incoherent account of Hamlet's voyage, drawing details from each of two quite distinct versions of the story - that underlying Q2, and that underlying the German Hamlet (or one similar to that). QI presupposes both of these, but gives neither properly. ${ }^{2}$ Now it would be absurd to suppose that the person responsible for QI drew directly upon the Brudermord itself. What he relied upon must have been a recollection of details from the version of the episode from which the German play derived it. This was not the prose sources (Saxo and Belleforest) any more than it was $\mathrm{Q}_{2}$ or F $\mathrm{I}$. It must then have been the old Hamlet play, mentioned by Nashe in 1589 . I cannot see what else it can have been. What lies behind the story told in QI xiv, then, is neither the Shakespearian nor the pre-Shakespearian version, but a garbled confusion of both.

One critic has voiced a general opinion of QI with which my conclusion in this particular instance agrees. In his monograph Shakespeare's "Hamlet" A. CluttonBrock refrains from any detailed discussion of $\mathrm{Q}_{\mathrm{I}}$; but in a parenthetical note 3 he gives an admirably succinct state-

${ }^{1}$ Note also that in $Q_{I}$ Horatio receives the news of Hamlet's adventures in a letter, as in $Q_{2}$ and $F_{1}$ (IV vi): there is no such letter in the Brudermord.

${ }^{2}$ To suppose that the episode in the Brudermord is based on $\mathrm{Qr}$ xiv would be as absurd as to suppose that the episode in $Q_{2}$ was based upon this same Qr xiv: we should have to maintain that, $Q_{1}$ giving a string of details which cannot be integrated into a consistent story, both Shakespeare and the person responsible for the Brudermord selected different details from it, and that each worked his set of details into a quite distinct fluent version of his own.

3 P. Ir. 
ment of what I regard as the true explanation of the pirated text as a whole. He says that QI "seems to consist partly of Shakespeare's work garbled and partly of fragments of the older play.... There is no reason to suppose that it gives us a version of the play which was at any time Shakespeare's own version. It seems rather a hotch-potch of Shakespeare and the older play, put together perhaps by some one who got Shakespeare's part of it furtively as well as imperfectly." I should add that he also got imperfectly the parts derived from the old play: in both cases he was relying solely on his memory.

The theory that in the old Hamlet the story of the hero's adventures during the voyage was similar to that in the Brudermord is supported by Mr F. T. Bowers, ${ }^{1}$ who finds that the play Alphonsus, Emperor of Germany, written probably between I 597 and I 599, was influenced by a Hamlet containing this episode, or one very like it. Now one point remains. Shakespeare's account of the voyage owes more to Belleforest than does that of the Brudermord, since the substitution of a new commission ordering the execution of the bearers is in Belleforest, where also Hamlet's escorts are two courtiers as in Shakespeare, not two hired ruffians as in the German text. ${ }^{2}$ On our hypothesis, therefore, we should have to suppose that Shakespeare reverted to a feature of the prose source which had been rejected by the author of the old Hamlet. This is quite possible. It may well be that the author of the old play wanted an episode which could be acted before the audience, an episode full of suspense and excitement. The actual alteration of the commission would take very little

I Modern Language Notes, vol. XLVIII (1933), pp. ror-8.

2 According to Belleforest, Amleth, during the voyage, reads the commission while his two companions are asleep, and alters it so that it orders not only the death of the bearers but also that Amleth should be allowed to marry the English king's daughter. They all arrive in England, where Amleth's escorts are put to death, and whence he himself subsequently returns to Denmark. 
time to perform, and it would be difficult to build a scene round it. Probably, therefore, the writer of the old play substituted a scene of action, invented by himself, and as a concession to his source made Hamlet discover the commission after the death of the two villains. Then Shakespeare, rejecting the notion of a scene of action and adopting the method of narration (inventing the story of the pirates' attack), reverted to the treatment of the commission found in Belleforest. ${ }^{\mathrm{I}}$

\section{THE CHARACTER OF THE QUEEN}

One of the most important arguments employed to support the theory that $Q_{I}$ represents a version of the play anterior to those of $\mathrm{Q}_{2}$ and $\mathrm{F}_{\mathrm{I}}$ is based on alleged differences of characterization between QI and the authentic texts. The. difference most heavily stressed is in the character of the Queen and her relationship to the other characters. Herford ${ }^{2}$ and $\mathrm{F}_{\text {urnivall }}{ }^{3}$, for example, use this as part of the evidence upon which they found their view that QI represents, though imperfectly, Shakespeare's first draft of the play. Robertson, 4 on the other hand, thinks that the Gertrude of $\mathrm{QI}_{\mathrm{I}}$ is the Gertrude of the old Hamlet.

There are two main points. First, in the Closet-scene in QI the Queen explicitly asserts that before Hamlet's revelation of the truth she had had no knowledge of the fact that her first husband was murdered; there is no such denial in the full play. Second, in the same scene in QI she offers Hamlet direct assistance in whatever plan he shall form for revenge; there is no such offer in the authentic texts. In the scene peculiar to QI (scene xiva conversation between the Queen and Horatio) she resolves to "soothe and please" the murderer for a while,

I See Bowers, op. cit. p. 107, footnote.

2 Harness Prize Essay (1880), pp. 33-5.

3 Introduction to Griggs's facsimile of $Q_{1}, \mathrm{pp}, \mathrm{v}-\mathrm{vi}$.

4 The Problem of "Hamlet", p. 73. 
presumably to lull his suspicions and thus help Hamlet to surprise him. In that scene she outspokenly condemns the King's treachery in his dealings with Hamlet, and lines herself up with him and Horatio against Claudius in a much more unequivocal fashion than either $Q_{2}$ or $F_{I}$ give us any warrant for supposing.

Comparing the "bad" and "good" texts in this connection we must try to discover first how great the difference really is, and second whether any difference there may be is necessarily to be referred to the reason advanced by Herford and Furnivall on the one hand or Robertson on the other.

The Queen's outright denial of all knowledge of the murder previous to Hamlet's disclosure occurs in QI xi 92-3:

But as I have a soule, I sweare by heauen, I neuer knew of this most horride murder.

Now Herford speaks of "the veil" which in $\mathrm{Q}_{2}$ is studiously drawn over Gertrude, concealing "the precise measure of her complicity in the murder", and Furnivall quotes this approvingly. ${ }^{\mathrm{I}}$ But granting that in $\mathrm{Q}_{2}$ she does not directly deny knowledge of the crime, it cannot be maintained that Shakespeare leaves her total innocence in doubt. Bradley's analysis of the character in the second Quarto is extremely acute:

... she was not privy to the murder of her husband, either before the deed or after it. There is no sign of her being so, and there are clear signs that she was not. The representation of the murder in the play-scene does not move her; and when her husband starts from his throne, she innocently asks him, "How fares my lord ?" In the interview with Hamlet, when her son says of his slaughter of Polonius,

"A bloody deed!" Almost as bad, good mother, As kill a king and marry with his brother,

I Introduction to Griggs's facsimile of $Q_{2}$, pp. xii-xiii. 
the astonishment of her repetition "As kill a king!" is evidently genuine; and, if it had not been so, she would never have had the hardihood to exclaim:

What have I done, that thou darest wag thy tongue In noise so rude against me?

Further, it is most significant that when she and the King speak together alone, nothing that is said by her or to her implies her knowledge of the secret. ${ }^{I}$

Dover Wilson re-emphasizes these points, ${ }^{2}$ noting also that before the Play-scene Gertrude and Claudius are alone together for only a moment: their conversation runs:

King. $\mathrm{He}^{3}$ tells me, my dear Gertrude, he hath found The head and source of all your son's distemper.

2ueen. I doubt it is no other but the main, His father's death and our o'erhasty marriage.

King. Well, we shall sift him.

(II ii $54-8$ )

Of the Queen's speech here Dover Wilson says that "she would surely not have phrased the matter thus had she entertained any suspicion at all of the real facts". 4 I agree: her innocence is quite clear.

Thus in making the Queen explicitly deny her knowledge of the murder the person responsible for the QI text is only putting more directly and crudely what is implicit in $\mathrm{Q}_{2}$ itself. $\mathrm{Q}_{1}$ being a pirated text, and there being ample room for adulteration by the reporter, there is no need to suppose that this denial ever stood in any Hamlet play. And when we find that it is embedded in a passage which is full of indications of memorial reconstruction, as has been shown at length in section VI of chapter IV, our suspicions of its value as evidence of the

I Shakespearean Tragedy, p. 166.

2 What Happens in "Hamlet", pp. 248, 252-3.

3 I.e. Polonius. $\quad 4$ Op. cit. p. $25^{2}$. 
dependence of QI upon an earlier Hamlet than that of Q2 are immeasurably increased. The denial is in all probability to be attributed solely to the reporter-versifier with whose handiwork we were concerned in chapter IV; and he has simply stated specifically what is inherent in the genuine text.

At the end of the Closet-scene in QI the Queen offers Hamlet her active assistance in his duty of revenge:

Hamlet, I vow by that maiesty,

That knowes our thoughts, and lookes into our hearts,

I will conceale, consent, and doe my best,

What stratagem soe're thou shalt deuise.

(xi $104-7$ )

As has already been noted, ${ }^{\mathrm{Y}}$ the last two lines here contain the words not of Gertrude in any authentic version of Hamlet but of Bellimperia in The Spanish Tragedy, Iv i 46 , with which is combined material from Hieronimo's rejoinder to her in Iv i 49. Boas and Robertson believed that the lines were a trace of the old Hamlet; on the contrary they are substantially an importation from another play. In view of this no inference can be drawn from QI xi 106-7 relative to the part played by Gertrude in the plot of Hamlet at any stage of its text-history, apart from the question whether the reporter would have confused the two characters Gertrude and Bellimperia had not the former at some stage of the Hamlet text-history acted in the same manner as the latter and so suggested the latter's words to his mind.

Robertson is certainly wrong when, with Sarrazin, Widgery, and Boas, he maintains that the presence in $Q_{I}$ of virtual quotations from $\mathrm{K} y d$ 's works indicates that these passages are survivals from the old Hamlet. But he has one very powerful argument for his position with regard to the part played in QI by the Queen. He and others point out that in those respects in which QI differs from I See p. I82. 
$\mathrm{Q}_{2}$ and $\mathrm{F}_{\mathrm{I}}$ it agrees with the prose story of Belleforest. ${ }^{\mathrm{I}}$ We must therefore examine Belleforest's account of the interview between Hamlet and his mother, and compare it with QI and with the authentic texts of the play.

After Amleth's harangue the Queen replies in Belleforest's tale with an admission that she did wrong in marrying Fengon, who corresponds to Claudius. But she claims a certain amount of justification, for the courtiers were all loyal to Fengon, and he had overwhelming power to turn against her if she resisted him. So Amleth should excuse her fault, rather than condemn her for licentiousness:

...quand tu considereras le peu de moyen de resistence, et la trahison de ceux du Palais, le peu de fiance que nous pouvons avoir aux courtisans tous faits à sa poste, et la force qu'il preparoit, là où j'eusse faict refus de son alliance, tu m'excuseras plustost que accuser de lubricité, ny d'inconstance, et moins me feras ce tort que de soupçonner que jamais Geruthe ait consenty à la mort de son espoux, te jurant par la haute majesté des Dieux, que s'il eust esté en ma puissance de resister au tyran, et qu'avec l'effusion de mon sang, et perte de ma vie, j'eusse peu sauver la vie de mon seigneur et espoux, je l'eusse fait d'aussi bon coeur, comme depuis j'ay plusieurs fois donné empeschement à l'accourcissement de la tienne, laquelle t'estant ravie, je ne veux plus demeurer en ce monde, puis que l'esprit estant sain, je voy les moyens plus aysez de la vengeance de ton pere. Toutesfois, mon filz, et doux amy, si tu as pitié de toy, et soin de la memoire de ton pere: et si tu veux rien faire pour celle qui ne merite point le nom de mere en ton endroict, je te prie de conduire sagement tes affaires, n'estre hasté, ny trop boüillant en tes entreprinses, ny t'avancer plus que de raison à l'effect de ton dessein. ${ }^{2}$

She goes on to say that they have none whom they can trust. Everyone at court is a potential spy for Fengon, who himself dissembles, pretending to love Amleth so that

I The Problem of "Hamlet", p. 73.

2 The Sources of "Hamlet" (Gollancz), pp. 220-2. 
he may continue to have his pleasure of her. He suspects that Amleth is not really mad, and if the latter should do anything which belies his pretence of idiocy Fengon will be informed. She fears that already Fengon has been told of what has passed between them during this very interview. Amleth's murder of the eavesdropper may be the undoing of them both, but for her part she will keep it secret as well as his sanity, praying the Gods to protect him and prosper his plans for vengeance, and looking forward to the time when he shall come into possession of the throne which is his by right. She will rejoice in the courage with which her son will take revenge upon the tyrannical murderer of his father and upon those who abetted him.

It is true that here Geruthe does not deny that she knew of the murder before her conversation with Amleth. She merely speaks of the wrong he does her in suspecting "que jamais Geruthe ait consenty à la mort de son espoux". Nor does she explicitly offer him her active assistance in the execution of his plans. But in Belleforest as in QI she unequivocally identifies her interests with those of Hamlet, against her husband whom she outspokenly condemns. She gives Amleth advice as to how to proceed, and she expresses the hope that he will succeed in overthrowing Fengon:

Now let us again consider QI scene xiv, the scene peculiar to that edition. Here the Queen gives Horatio a message for Hamlet:

\section{bid him a while}

Be wary of his presence, lest that he

Faile in that he goes about.

(xiv I9-2I)

I have already shown that this passage combines words recollected from two earlier passages in the $Q_{2}$ text"be wary" from I iii 43, "of (his) presence" from I iii I 2 I. So much for the phrasing, doubtless the work of our 
reporter-versifier. But it is highly significant that the purport of these lines of QI is exactly that of a passage quoted above from Belleforest: the Queen says to Amleth je te prie de conduire sagement tes affaires, n'estre hasté, ny trop boüillant en tes entreprinses, ny t'avancer plus que de raison à l'effect de ton dessein.

The conclusion is inescapable that the passage in $\mathrm{Q}$ is ultimately based on that in Belleforest; the two are remarkably close, and there is nothing to correspond in the texts of $\mathrm{Q}_{2}$ and $\mathrm{F}_{\mathrm{I}}$.

We must now look once again at the following passage towards the end of the QI version of the Closet-scene:

(Ham.) And mother, but assist mee in reuenge,

And in his death your infamy shall die.

2ueene. Hamlet, I vow by that maiesty,

That knowes our thoughts, and lookes into our hearts,

I will conceale, consent, and doe my best,

What stratagem soe're thou shalt deuise.

(xi $102-7$ )

We have noted that in the last two lines here the reporter has borrowed from The Spanish Tragedy. But consider the second line, where Hamlet speaks of his mother's "infamy". This very word appears in Belleforest in the chapter corresponding to the Closet-scene in the play, also in a speech by Amleth to the Queen:

$\mathrm{Au}$ reste, Madame, ne plourez point pour l'esgard de ma folie, plustost gemissez la faute que vous avez commise, et vous tourmentez pour celle infamie qui a souillee celle ancienne renommee, et gloire qui rendoit illustre la Royne Geruthe. ${ }^{\mathrm{I}}$

Here "infamie" refers to the same conduct as does the word in QI.

Consider also the next line in our extract from $\mathrm{Q} r$ : it too contains a remarkable parallel to a passage already quoted from Belleforest. Having denied complicity in the

I The Sources of "Hamlet", p. 216. 
murder of her first husband, Geruthe continues, "jurant par la haute majesté des Dieux" that had it lain in her power she would have saved his life. QI echoes the words of the oath, the Queen swearing "by that maiesty".

Faced with the fact that in certain features peculiar to itself among the dramatic texts of Hamlet $Q_{1}$ agrees with the prose source of the play, and arguing for the proposition that QI owes nothing to any Hamlet drama anterior to the version of $Q_{2}$, Signor Giovanni Ramello concludes that the compiler of the QI version himself consulted Belleforest's text. ${ }^{2}$ This is not impossible, but it seems rather forced. And there is something positive to be said against it.

In the very much attenuated version of the Closetscene given in Der Bestrafte Brudermord there are certain passages to which there is nothing corresponding in the other texts of the play but which present interesting parallels to passages in Belleforest.

Hamlet having left her, the Queen in a soliloquy blames herself for his evident madness:

Ach Himmel, wie hat doch die Melancholie diesen Prinzen so viele Raserey zugebracht! Ach, mein einziger Prinz hat seinen Verstand ganz verloren! Ach, ach, ich bin viel Schuld daran! Hätte ich meinen Schwager, meines vorigen Gemahls Bruder, nicht zu der Ehe genommen, so hätte ich meinem (Sohn) nicht die Krone Dännemark aus der Hand gespielt. (III vi I 5 ff.)

In neither the $Q_{1}$ nor the $Q_{2}$ and $F_{I}$ versions of the Closet-scene is there anything resembling this; but in the chapter which corresponds to this scene Belleforest has a passage which is parallel in certain respects. After Amleth's departure with the corpse of the murdered eavesdropper, Queen Geruthe's conscience is affected by the spectacle of his wild behaviour: she is grieved

I The Sources of "Hamlet", p. 216.

2 Studi sugli Apocrifi Shakespeariani: Hamlet, 1603, pp. 174-6. 
voyant que ce seul fils qui luy restoit ne luy servoit que de mocquerie, chacun luy reprochant sa folie, un trait de laquelle elle en avoit veu devant ses yeux: ce qui luy donna un grand elancement de conscience, estimant que les Dieux luy envoyassent ceste punition, pour s'estre incestueusement accouplee avec le tyran meurtrier de son espoux. ${ }^{\text {I }}$

Both here in Belleforest and in the German text the Queen blames herself as the ultimate cause of Hamlet's supposed insanity. It is true that they differ as to the immediate cause which she adduces: in Belleforest she thinks that her son's madness is a divine punishment imposed on her for her incestuous second marriage; in Der Bestrafte Brudermord she apparently thinks that Hamlet's insanity is the result of his intense disappointment at having been robbed of the Danish crown - a deprivation which followed from her marriage with the late King's brother. It is also true that in quite another part of the full Shakespearian play there is a speech which could be regarded as parallel to these: in Q2 II ii 54-7 Claudius tells the Queen that Polonius claims to have discovered the reason for Hamlet's indisposition, and she replies

I doubt it is no other but the main,

His father's death and our o'erhasty marriage.

Here, however, her conscience is not aroused; she is not thinking of the marriage as wrong, nor is she emphasizing her own responsibility for Hamlet's condition. In these particulars the passage in $\mathrm{Q}_{2}$ disagrees with those in the French and German texts, which agree with each other not only in them but in placing the passages in question in the Closet-scene, in each case immediately after an exit of Hamlet (though not directly corresponding exits).

Creizenach pointed out another parallel between Belle-

I The Sources of "Hamlet", pp. 206-8. 
forest and the Brudermord in the Closet-scene. ${ }^{\mathrm{I}}$ In the latter the Queen declares that she can hardly restrain her tears when she thinks of her dead husband, and Hamlet rejoins: "Weint ihr? ach, lasts nur bleiben, es sind doch lauter Crocodillsthränen." Similarly in Belleforest, at the beginning of Amleth's harangue to his mother, he says of her and her like that "souz le fard d'un pleur dissimulé vous couvriez l'acte le plus meschant, et le crime le plus detestable, que homme sçauroit imaginer, ny commettre". Creizenach regarded this as pure coincidence. One may rather agree with Corbin, who thinks that Hamlet's words in the Brudermord read like "a right Elizabethan version" of those in Belleforest. ${ }^{2}$

Again, in both the Brudermord and Belleforest Hamlet expresses a desire to exact vengeance from the $\mathrm{King}$ in such a way that it will be for ever famous. In the former he says to Horatio at the end of I vi: "Ich will mich an diesen Kronsüchtigen, an diesen Ehebrecher und Mörder also rächen, dass die Nachwelt der Ewigkeit davon nachsagen soll." This closely parallels two passages in Belleforest: (i) "Mais le galant les marquoit avec intention de s'en venger un jour avec telle effort, qu'il en seroit à jamais memoire", 3 and (ii) — spoken by Amleth — "Car les desirs de le venger sont tellement gravez en mon coeur, que si bien tost je ne meurs, j'espere d'en faire une telle et si haute vengeance qu'il en sera à jamais parlé en ces terres". 4 There is absolutely nothing in the texts of QI, $\mathrm{Q}_{2}$ or F I to correspond to this.

In Der Bestrafte Brudermord, then, there are passages which closely resemble passages in Belleforest, and these

I Berichte über die Verhandlungen der königlich-sächsischen Gesellschaft der Wissenschaft zu Leipzig: Philologisch-Historische Classe, I887, p. 30 .

${ }^{2}$ Harvard Studies and Notes in Philology and Literature, vol. v (1896), pp. 256-7.

3 Gollancz, Sources of "Hamlet", p. 194.

4 Ibid. p. 216. 
passages in the German text are not paralleled in QI. Nor does the German text parallel the passages in the QI version of the Closet-scene which I have quoted as closely resembling other passages in Belleforest. Signor Ramello would be forced to propound the theory that two memorial reconstructors had recourse to Belleforest independently. This seems a truly desperate attempt to avoid the obvious hypothesis that where QI (and the Brudermord) parallel Belleforest closely against the other English dramatic texts they preserve traces of passages in the old Hamlet which had been based upon those in Belleforest. Despite all that has been said to the contrary, I believe that this remains the most probable view. When he wrote Qi xi 103-4, the reporter, on this hypothesis, remembered material from the Closet-scene in the old Hamlet, material based on two separate passages in the corresponding chapter in Belleforest-one in which Amleth speaks of his mother's "infamie", the other in which the Queen swears "par la haute majesté des Dieux"; he then immediately proceeded, intentionally or involuntarily (by memorial confusion), to borrow a passage from The Spanish Tragedy, IV i 46-50. Similarly, when he wrote QI xiv I9-2I, he remembered a passage in the old Hamlet directly based on that in Belleforest where the Queen pleads with Amleth to exercise caution; ${ }^{\mathrm{I}}$ but, though remembering the tenor of this, he used words of his own finding, words derived by him from I iii of Shakespeare's play $\left(Q_{2}\right)$. Thus at both points in this scene where Belleforest is echoed ( $e x$ hypothesi indirectly) there is independent evidence of

I There is a similar passage in Der Bestrafte Brudermord, where, at the end of II ix, Horatio says to Hamlet "Ihro Durchlaucht sehen sich aber wohl vor, dass Sie nicht auch zu Schaden kommen". If in the old Hamlet play the hero was warned to be careful, it would seem more likely that the warning was issued by the Queen, as in Belleforest and $Q_{I}$, than by Horatio as in the German text, which is also obviously a memorial reconstruction of some sort and which need not therefore be taken to represent any source with exactitude. 
memorial transmission. This again suggests that the words which we have traced to Belleforest were also echoed by memorial confusion and not as a result of direct consultation of the work; and it is very much more likely that the reporter responsible was echoing words from a play based on Belleforest than that he was remembering phraseology from the prose tale directly. For throughout QI we can see the handiwork of someone connected with the theatreeven in the blank verse peculiar to that text, where the tissues of fragments of this and even other plays indicates a former intimacy with them. Again, if the purveyor of the QI text had had access to a copy of Belleforest (which would then be his only document, apart from Voltemar's manuscript part), we should expect that greater use would have been made of it.

I am inclined, therefore, to accept the theory that in certain passages bearing on the part taken by the Queen in the drama the reporter or reporters were influenced by recollection of the old Hamlet play. The question of the extent of this debt (apart from the isolated verbal reminiscences which I have suggested) is a hazardous one. In Belleforest the Queen neither offers nor is asked for active assistance in Hamlet's plans for revenge: in this QI is at variance with the prose source. Again, in making her deny knowledge of the murder before the interview with Hamlet in the Closet-scene QI disagrees with Belleforest, in whose account she appears to know of the murder all the time and in the Closet-scene simply deny complicity. ${ }^{\mathrm{I}}$ But in any case we cannot assume that the old play followed Belleforest slavishly; and, on the other hand, we have to

I After Amleth has departed with the body of the murdered eavesdropper, but before his harangue to his mother, the latter, in a passage of conscience-stricken reflection already quoted, considers that his madness is a divine punishment imposed on her for her incestuous marriage with "le tyran meurtrier de son espoux". Here Belleforest is obviously giving in oratio obliqua the Queen's own thoughts. It follows therefore that she knows of the fact of the murder. 
reckon with the possibility of the reporter using his invention in passages unique in it. It would not, however, be unreasonable to suppose that in the old Hamlet the Queen adopted in general a much more definite position with Hamlet and Horatio against the King than in Shakespeare, and that in this matter the QI reporter followed the old play at the end of the Closet-scene and in scene xiv, ${ }^{\mathrm{I}}$ but not elsewhere. We would in that case posit contamination of what is essentially a reported version of Shakespeare's final play by occasional reminiscences of the character-relationships of the old play. There is no question that in general throughout $Q$ I the Queen represents the Queen of Shakespeare (Q2); and although at certain points she may have been confused with the Queen of the old Hamlet (just as she also was with Bellimperia), it must be noticed that the character-relationship peculiar to QI among the extant texts is dramatically useless and otiose in that version itself. ${ }^{2}$ For in QI the Queen does not assist Hamlet actively, nor does her unequivocal siding with him have the slightest effect upon the plot. Moreover, it renders her conduct during the fencing-scene inexplicable, since she does not appear to have the slightest suspicion of the King's good faith (although from scene xiv we should expect her to have) and acts indeed exactly like her counterpart in $Q_{2}$. One might say that in this she is executing her resolve to "soothe and please" the King (QI xiv I 2), but even so this artifice would be dramatically supererogatory. Her position as a direct adversary of the King, aware of all his crime, a position she takes up in QI in the Closet-scene and in scene xiv, if it is indeed based upon the old play,

I I am here concerned only with her expressed attitude to Hamlet and to the King in scene xiv, not with the question of whether such a scene ever stood in any Hamlet text other than $Q \mathrm{r}$.

2 See E. E. Stoll, “'Hamlet' and 'The Spanish Tragedy' Again”, Modern Philology, vol. xxxvII (1939), p. 183 . 
is not assimilated to her characterization in the remainder of QI : so, even if the derivation of this material from the early drama be accepted, the most probable explanation is that QI is essentially a report of the full Shakespearian play, at certain points in which that play is confused with the earlier one. Just as two incompatible versions of Hamlet's voyage have been forced together absurdly, without integration, so two separate rôles of the Queen towards the end of the play have been wrenched together without fusion.

IV. THE POSITION OF THE "NUNNERY" SCENE There is an important difference in scene-sequence between QI and the authentic Shakespearian texts. In QI the meeting between Hamlet and Ofelia (preceded by the soliloquy "To be or not to be") occurs immediately after it is planned by Corambis and the King. In Shakespeare the formation and execution of the plan are separated by a number of episodes - the "fishmonger" dialogue (II ii I68-222); Hamlet's conversation with Rosencrantz and Guildenstern (223-383), during which they mention the arrival of the players; Polonius's announcement of the players' arrival, and the "Jephthah" dialogue (384-425); Hamlet's conversation with the players, including the "Pyrrhus" speech (426-55I); the soliloquy "O what a rogue and peasant slave am I" (552-609); Rosencrantz's and Guildenstern's report to the King and Queen about Hamlet's mental condition and their inability to probe it to its roots (III i $\mathrm{I}-28$ ). All these episodes are represented in $\mathrm{Q}_{\mathrm{I}}$ in that order, but after the soliloquy "To be or not to be" and the "nunnery" scene. The question before us is whether the scene-sequence of QI is that of a Hamlet earlier than that of $Q_{2}$, or whether it is an alteration of the sequence of $\mathrm{Q}_{2}$ and $\mathrm{F}_{\mathrm{I}}$, made deliberately or involuntarily. 
Gustav Tanger, ${ }^{\mathrm{I}}$ maintaining that $\mathrm{Q}_{1}$ imperfectly represents the play as contained in $\mathrm{Q}_{2}$, and no other at any point, attributes what he regards as a structural alteration to the reporter's carelessness. Compare the two versions of Corambis-Polonius's plan:

Q2: Pol. You know sometimes he walks four hours together Here in the lobby.

2ueen. So he does indeed.

Pol. At such a time I'll loose my daughter to him.

Be you and I behind an arras then,

Mark the encounter, if he love her not,

And be not from his reason fall'n thereon,

Let me be no assistant for a state,

But keep a farm and carters.

King.

We will try it.

Qr: (Cor.) The Princes walke is here in the galery,

(II ii $160-7$ )

There let Ofelia, walke vntill hee comes:

Your selfe and I will stand close in the study,

There shall you heare the effect of all his hart,

And if it proue any otherwise then loue,

Then let my censure faile an other time.

(vi 105-ro)

Here the QI version is, according to Tanger, a clumsy attempt at rendering that of $Q_{2}$, but the reporter has made some mistakes which get him into trouble. The lines in $\mathrm{Q}_{1}$ do not state, as do those of $\mathrm{Q}_{2}$,

that the Prince walks only sometimes in the gallery, but "The Princes walke is here in the gallery", i.e. he walks there regularly. They do not say that Polonius is going to "loose his daughter to him 'at such a time"', but they show Corambis's intention of carrying out his design without delay:

There let Ofelia walke vntill hee comes. I $72-4$.

I Transactions of the New Shakspere Society, I880-2, Part I, pp. 
$\mathrm{X}$ [i.e. the reporter] was thus driven into a corner by his own improvidence and had to transpose, or rather insert, the scene in question (together with a portion of the dialogue between the King and Corambis consequent upon it), so as to make it follow immediately after Corambis's proposal. ${ }^{\mathrm{I}}$

There are two powerful objections to this explanation, which is far too simple; and Tanger seems aware of both, though not apparently of their force. He points out ${ }^{2}$ that Grant White was in error in supposing that Ofelia was not on the stage in QI when she was wanted for her encounter with Hamlet. Actually her entry is noted in QI at the point corresponding to II ii 39 of the authentic text (i.e. at vi I 8), although she is utterly ignored for no less than 96 lines, until her father says, at vi I I 5-16,

And here Ofelia, reade you on this booke, And walke aloofe, the King shal be vnseene.

The only reason for Ofelia's entry at vi i 8 is that she shall be ready at vi I 5 for the part she is to play. Thus the reporter's misrepresentation of II ii $160-7$ cannot have been the precipitating cause of the alteration in scene-sequence, which is carefully prepared for nearly a hundred lines earlier - unless indeed he went back and inserted Ofelia's name in the stage-direction at vi I 8 after having been forced "by his own improvidence" into making the alleged structural alteration. And that this did not happen there is fairly clear evidence, which will be noted below. The second objection to Tanger's hypothesis is his own analysis of the extremely careful adaptation of the text to the new sequence. It is scarcely reasonable to hold that a reporter who clumsily "drives himself into a corner by his own improvidence" will have the great technical skill necessary to effect the adaptation which Tanger postulates and describes.

$$
\text { I Op. cit. p. I73. }
$$


William Poel ${ }^{\mathrm{I}}$ also maintained that the scene-sequence of $Q_{1}$ post-dates that of $Q_{2}$, but he does not share Tanger's inconsistency. He argued that the text of QI is a reported version of a very careful stage-adaptation of the playhouse copy which later became the basis of the Folio text. $\mathrm{He}$ visualized a practical purpose for the alleged structural alteration which we are considering. By the time the "nunnery" scene is enacted in the full version, the average audience may well have forgotten Polonius's plan, ${ }^{2}$ and may therefore fail to understand what is even apart from this an extremely difficult scene. The greater lucidity and dramatic simplicity of the QI sequence has not infrequently been noted, most recently by Mr Harley GranvilleBarker. ${ }^{3}$

Both Tanger and Poel ignore an inconsistency present in the text of $\mathrm{Ir}$ in $\mathrm{Q}_{2}$ and $\mathrm{F}_{\mathrm{I}}$. Ophelia enters to tell Polonius her agitated tale of Hamlet's queer behaviour in her boudoir. Polonius immediately takes this as a proof of his thesis that Hamlet's madness is caused by "the very ecstasy of love", and determines that the King shall hear of it at once. "Come go with me", he says in line 98, "I will go seek the king"; and then in line I I4 "come, go we to the king". This last is inconsistent with the subsequent action, for at II ii 39 Polonius alone enters. In QI, on the other hand, II i 98 is ignored and II i I I 4 reproduced in modified form as "Lets to the King" (v 65 ): and accordingly, as we have seen, both Corambis and Ofelia enter at the point corresponding to II ii 39 , though Ofelia

I The Athenaeum, 1900, p. 316; Notes and 2ueries, Series 12, vol. XI (1922), pp. 30I-3; The Bookman's Fournal, vol. xIr, no. 43 (April 1925), pp. 3-5.

2 In the full text the plan is hatched nearly 500 lines before its execution (this leaves out of account the possibility of abridgement in performance). It is of course to be remembered that the audience is reminded of the plan immediately before it is put into effect (III i 29-37).

3 Prefaces to Shakespeare, Third Series, p. 196.

D BQ 
is ignored for 96 lines. $^{\mathrm{I}}$ Sir Edmund Chambers, also holding that the QI scene-sequence is an alteration of that in $\mathrm{Q}_{2}$ and $\mathrm{FI}_{1}$, suggests as a possible reason for the change that "it was an attempt to remove an original inconsistency, characteristic enough of Shakespeare, by which Ophelia is bidden to accompany her father to the King in II $\mathrm{i}$, but left out in II ii". ${ }^{2}$. He apparently believes that the inconsistency in II i was the result merely of momentary negligence on Shakespeare's part, and this is a reasonable view. Others regard it as evidence of careless revision: this is the view taken by Professor E. E. Stoll, 3 and, more tentatively, by Mr Granville-Barker.4 According to this view, we have in $Q_{2}$ and $F_{I}$ a revision of a version in which the planning of the encounter between Ophelia and Hamlet and the execution of the plan were contiguous; Shakespeare has separated them, but has accidentally left in his text a trace of the older arrangement, viz. the words "come, go we to the king" in II i I I 4. Professor Stoll considers this to be a trace of the pre-Shakespearian play; $\mathrm{Mr}$ Granville-Barker inclines rather to refer it to a Shakespearian version anterior to that of $Q_{2}$, that is to a "first sketch".

In view of the possibility that the inconsistency in $\mathrm{Q}_{2}$ II $\mathrm{i}$ may be the result simply of momentary carelessness on Shakespeare's part, or of a momentary hesitation as to how the plot was to continue, we cannot regard it as evidence that the QI scene-sequence is that of a Hamlet earlier than that of $\mathrm{Q}_{2}$. Meanwhile there emerges a very strong point in favour of the opposite theory, a point first made by Richard Grant White. ${ }^{5}$ The point itself is important, although one may not entirely agree with the use which Grant White makes of it.

I This point completely destroys Tanger's case.

2 William Shakespeare, vol. I, p. 4I7.

3 Modern Philology, vol. xxxv (1937-8), p. 36.

4 Prefaces to Shakespeare, Third Series, pp. 194ff.

5 The Atlantic Monthly, vol. XLvirr (I88r), pp. 475-6. 
In the authentic Shakespearian play, immediately after Polonius has enunciated his plan for Ophelia's encounter with Hamlet, the latter enters reading a book. This is specifically stated in the text: the Queen directs attention to his approach by saying

But look where sadly the poor wretch comes reading.

(II ii I68)

Polonius sends the King and Queen away, and the "fishmonger" dialogue ensues, in the course of which further reference is made to the fact of Hamlet's reading:

(Pol.) What do you read, my lord?

Ham. Words, words, words.

Pol. What is the matter, my lord?

Ham. Between who?

Pol. I mean the matter that you read, my lord.

Ham. Slanders, sir....

(II ii I 9 I-6)

Later, when Polonius sets the scene for the execution of his plan, he instructs Ophelia to "Read on this book" (III $\mathrm{i}$ 44): a few lines further on Hamlet enters, soliloquizing, "To be or not to be"-he is not reading.

Now let us consider the corresponding circumstances in Q1. Immediately after Corambis has formulated his plan Hamlet enters reading. Just as in the genuine texts the Queen draws attention to this, so does the King in $Q_{1}$ :

see where hee comes poring vppon a booke.

(vi I I I)

But the "nunnery" scene is to follow now, so Ofelia too must perforce be reading her book-the book which is mentioned in the full play at III i 44 . Corambis gives her her instructions:

reade you on this booke,

And walke aloofe....

(vi I I 5-I6) 
In QI, then, both Hamlet and Ofelia are reading at the beginning of the "nunnery" scene. But whereas the fact that Ofelia is reading has the same dramatic value as in IIr i 44 in the authentic version, no use whatever is made of the fact that, according to the King, Hamlet is reading. Now let us turn to the end of the "nunnery" scene in QI. At vi 200 Hamlet storms out in frenzy with his reiterated exclamation "to a Nunnery goe". Twelve lines later, for no appreciable reason, he returns, and the "fishmonger" dialogue follows, during which there occurs a tolerably accurate reproduction of the conversation already quoted from In ii I 9 I ff.: at vii I4-I9 QI has

Cor. What doe you reade my Lord?

Ham. Wordes, wordes.

Cor. What's the matter my Lord?

Ham. Betweene who?

Cor. I meane the matter you reade my Lord.

Ham. Mary most vile heresie:...

But how can Hamlet be reading here in QI ? He has just finished his violent interview with Ofelia, and rushed out practically demented with passion. Are we to suppose that only a dozen lines later he returns reading a book? Surely this absurdity is the result of the reporter having followed the authentic Shakespearian text, while altering the sequence of the episodes. When in vi I I I the King draw attention to the approach of Hamlet "poring vppon a booke", Hamlet enters, not reading but meditating upon suicide-a subject surely suggested to him by his own sorrows and difficulties; ${ }^{\mathrm{I}}$ when at vii I4 Corambis asks

${ }^{1}$ W. H. Widgery (Harness Prize Essay, 1880, pp. 128-9) admits the awkwardness in both Hamlet and Ofelia having books in their hands at the beginning of the nunnery-scene in Qr. But he upholds the order of episodes there as that of a first sketch, supposing that in it the soliloquy was suggested to Hamlet by a passage in the book he was reading. He does not, however, appreciate the absurdity of making Hamlet read just before vii $\mathrm{I}_{4}$, and this vitiates his argument. 
him what he is reading, he cannot in fact be reading at all except with the grossest dramatic absurdity (which I should not care to attribute to a Shakespearian first cast, or even to the old play). Retain the Q I text and restore the $\mathrm{Q}_{2}$ sequence: then, and then only, will consistency be achieved in the former, and QI vi I I and vii I4 will fall neatly into place. I am in confident agreement with those who regard the QI scene-sequence as an alteration of that in $Q_{2}$ and the Folio - an alteration which has resulted in an inconsistency.

The fact that in Q1 Ofelia's entrance is noted in the stage-direction at vi 18 results in another dramaturgical weakness, inasmuch as she is present as a silent auditor of a discussion of her relations with Hamlet, a discussion conducted exactly as if she were not there (vi 64-99). We are reminded of this by Fitzgerald, ${ }^{I}$ who gives another interesting example of imperfection consequent upon the QI sequence being improperly accommodated to the text, which implies the sequence of $Q_{2}$. In vi 58-95 Corambis gives the King what he regards as proof positive that Hamlet's madness is caused by love of Ofelia. The King remains doubtful, however, thereby considerably dashing the counsellor's spirits. ${ }^{2}$ In QI, as well as in the accredited texts, it is clear that the latter's plan for the meeting between Hamlet and Ofelia is formulated in order to convince the King of a theory which Corambis-Polonius had thought would be plain to him from the evidence just submitted - the evidence of Hamlet's love-letter and his reaction to Ofelia's avoidance of him. It is the King's hesitant reception of his information which prompts him to form a further plan. Now in QI the "nunnery" scene immediately follows its conception in Corambis's mind; yet not only does Ofelia have the necessary apparatus, but

I The First 2uarto of "Hamlet": a Literary Fraud (rgro), pp. 29-36.

${ }_{2}^{2}$ See $Q \mathrm{r}$ vi $96 \mathrm{ff}$., and, in the full play, Ir ii ${ }_{5} \mathrm{Iff}$. 
quite uninstructed she knows what to do with it-she tries to restore to Hamlet the "small remembrance", the "tokens", which he had given her. In QI the only opportunity for Ofelia to receive instructions to return the tokens is while vi $\mathrm{I}-\mathrm{I} 8$ are being spoken on the stage: yet here, if I am right, the plan has not yet occurred to Corambis. And it is inconsistent with the character of Ofelia in QI as well as in the other texts to suppose her capable of leading Hamlet on without specific directions. No such difficulty appears in $\mathrm{Q}_{2}$ or $\mathrm{F}_{\mathrm{I}}$, whose sequence is again necessary to render the QI version coherent.

Now let us return to the inconsistency left by Shakespeare in the text of II $\mathrm{i}\left(\mathrm{Q}_{2}\right.$ and $\left.\mathrm{F} \mathrm{I}\right)$. While upholding as reasonable the view that it is simply a characteristic piece of Shakespearian negligence indicating a change of plan made during the composition of the scene, I would not deny great plausibility to the theory that it indicates careless revision, Shakespeare retaining in II i I I 4 a trace of an earlier version in which the planning and staging of the "nunnery" scene were in juxtaposition. But I would say that if this is so the QI reporter has, in altering the sequence of $Q_{2}$, reverted to this earlier juxtaposition: I would not say that he had reverted to the scene-sequence of the old play, for, accepting the revision theory of $\mathrm{II} \mathrm{i}$, all that we could say would be that the planning and the carrying out of the test were contiguous. We could not say whether the old play contained anything to correspond to the material which intervenes in $\mathrm{Q}_{2}$ and $\mathrm{F}_{\mathrm{I}}$, and which is represented in QI, out of position. To sum up: $Q_{1}$ here presupposes the text and sequence of $Q_{2}$; the sequence has been altered in $\mathrm{QI}$; and the altered sequence may in one particular agree with an earlier version of the play.

Despite the inconsistency consequent upon the alteration, QI is not without indications of a careful attempt to fit an imperfect representation of the $Q_{2}$ text to the new 
sequence. After the "nunnery" scene in Q2 the King and Polonius sustain a conversation (III i I 65-9I), with two passages of which we are concerned. The King repudiates Polonius's theory that Hamlet is mad for love (lines 165-70), and Polonius suggests that the Queen interview her son after the Gonzago play (lines 183-8). In QI these two passages are neatly separated. The former is sketchily represented in the corresponding position, immediately after the "nunnery" scene:

\section{King Loue? No, no, that's not the cause, Some deeper thing it is that troubles him.}

(vii $\mathrm{I}-2$ )

The latter is represented at the end of scene viii (lines 24-40), that is immediately after the material corresponding to III i I-28 where Rosencrantz and Guildenstern deliver Hamlet's invitation to the King and Queen to attend the Gonzago play. This occurs just before the "nunnery" scene in $\mathrm{Q}_{2}$ and $\mathrm{Fr}_{1}$; and inasmuch as that scene has already been enacted in QI, the result of the addition to scene viii of a passage corresponding to III $\mathrm{i}$ I $8_{3}-8$ is that the current of the scene-sequence of $\mathrm{Q}_{2}$ and $\mathrm{F}_{\mathrm{I}}$ is cleverly regained.

The link between the "nunnery" scene and the "fishmonger" dialogue in QI is very well managed:

King. Loue? No, no, that's not the cause,

Some deeper thing it is that troubles him.

Cor. Wel, something it is: my Lord, content you a while,

I will my selfe goe feele him: let me worke,

Ile try him euery way: see where he comes,

Send you those Gentlemen, let me alone

To finde the depth of this, away, be gone.

Now my good Lord, do you know me?

Ham. Yea very well, y'are a fishmonger.

exit King

Enter Hamlet

(vii $\mathrm{I}-9$ )

Here Corambis gives a satisfactory explanation of why he should accost Hamlet immediately after the "nunnery" 
scene: this test of Hamlet having failed, another is at once to be undertaken. In addition to this, his speech also prepares for the following of the "fishmonger" scene by the meeting of Hamlet with Rosencrantz and Guildenstern; for Corambis dispatches the King to send them. The passage provides an extremely successful link, adapting the text to its altered sequence.

This link-passage was composed in the same way as those which we examined in chapter IV. Many of the phrases employed can be traced to various passages in the genuine texts. The King's exclamation "Loue?" is taken direct from In i 165 . The word "cause" is used in connection with Hamlet's alleged madness in II ii 49 and IOI, III i 6, and III ii 338. In the King's statement that it is something deeper which "troubles him" there is probably a debt to $\mathrm{I}$ ii 224 where, speaking of the reported appearance of the Ghost, Hamlet says "this troubles me". Corambis answers with the words "something it is": here the reporter was probably influenced by a vague recollection of $\mathrm{mI}$ i $167-8$ :

there's something in his soul,

O'er which his melancholy sits on brood,... .

The phrase "content you a while" may well be a vague anticipation of IV v 209, where the King says to Laertes

Be you content to lend your patience to us. ${ }^{\mathrm{I}}$

Here the King is saying in effect "leave this to me", just as Corambis is saying in our passage. When he gave Corambis the words "let me worke" the reporter may have been drawing on a dim memory of II ii I 39, where, describing his efforts to keep Ophelia and Hamlet apart, the same speaker says "I went round to work". Then Corambis says "Ile try him euery way" (i.e. test him):

I Cf. the corresponding line in Qr (xiii Ir7) "Content you good Leartes for a time." 
the verb "try" is used in the same sense in II ii I 59. "Send you those Gentlemen" echoes the phrasing of II ii 37 where the Queen directs attendants to "bring these gentlemen where Hamlet is". Corambis proceeds with "let me alone to finde the depth of this". These two words, used here in reference to Corambis's testing of Hamlet, were derived by the reporter from the passage in the authentic version where the Queen's testing of Hamlet is planned: in IIr i $185-6$ Polonius says "Let his queenmother all alone entreat him/To show his grief", and a line or two later he continues "If she find him not,/To England send him". Finally, in QI vii 7 Corambis exclaims "away": the source of this is II ii 169 , in which Polonius says to the King and Queen "Away, I do beseech you both, away".

It seems, then, that our reporter-versifier has devised this neat link between the "nunnery" and "fishmonger" scenes, employing his characteristic method of composition. If it were not for the inconsistency with which we dealt earlier, his adaptation of the Shakespearian text (or rather a reported version of it) to the altered sequence would be perfect. Even as it is, it is skilful enough for us to suppose that it was deliberate and not simply the result of bungling. ${ }^{\mathrm{I}}$

But what was the reason for the alteration? There is more than one eligible answer, and no final pronouncement is possible. We have noted Tanger's solution. That of Grant White is not dissimilar. He points out that in the authentic text Hamlet has a book at II ii I $68 \mathrm{ff}$., and Ophelia has a book at III i $44 \mathrm{ff}$. According to his hypothesis, the reporter, confused, transferred Ophelia and her book to the scene which involved Hamlet and his. ${ }^{2}$ If we accepted the theories of either of these critics we should have to suppose that, having made a bad initial blunder,

${ }^{I}$ A point already made against Tanger.

2 Op. cit. p. 475 . 
the reporter made conscious and partially successful efforts to annul its effect. I incline much rather to the theory of deliberate alteration from the very first. The reporter may, as Sir Edmund Chambers suggests, have been anxious to remove the Shakespearian inconsistency in Q2 Ir i. But if so, he has adopted an unnecessarily troublesome way of achieving his object. It would have been perfectly simple to write "I'll to the King" in v 65 , instead of "Lets to the King", copying In i 98 instead of II i I 4 . No structural alteration would then have been called for. The most reasonable hypothesis is probably that of Poel, postulating behind QI a stage-version in which this sequential change has been made of set purpose.

Though differing in certain respects, Der Bestrafte Brudermord contains essentially the same scene-sequence here as does $\mathrm{Q}$. Corambus comes in to tell the $\mathrm{King}$ and Queen that Hamlet is mad; Ophelia enters and tells the three of them that Hamlet is plaguing her; Corambus suggests that the King and he should watch a meeting between Hamlet and Ophelia; the Queen is sent away and the "nunnery" scene immediately follows; then the King dismisses Corambus and in a soliloquy declares that Hamlet's "insanity" is pretence and that he must be got rid of; then follows a short scene between Hamlet and Horatio, to whom presently Corambus enters with news of the arrival of the players; Hamlet resolves to stage the play-scene, and his interview with the players then takes place; after their exit he instructs Horatio to watch the King during the performance, which then follows. It will be seen that there are certain differences here between the Brudermord and all the English texts: the total absence of the "fishmonger" dialogue is only one of these. But Tanger was certainly correct in calling attention to the essential identity of sequence in $\mathrm{Q} I$ and in the German version-the "nunnery" scene occupies the same position in both. 
Different theories might be advanced to explain this substantial identity of sequence in these two texts, thus:

(I) If it is held that, though the QI sequence is certainly a subsequent alteration of that of $\mathrm{Q}_{2}$, it reverts to the sequence of an earlier version of Hamlet, it might be supposed that the Brudermord independently preserves the sequence of that earlier version.

(2) It might be supposed that as far as the sequence here is concerned, the Brudermord is actually based on that of the $Q_{1}$ version (in which the alteration of the $Q_{2}$ sequence had been made probably for acting purposes), although the "fishmonger" dialogue is omitted and other changes made.

(3) It might be supposed that both the Qr text and that of the Brudermord are independently based on a stageversion in which the $Q_{2}$ sequence had been altered.

Of these explanations the first is by far the least probable. It depends entirely on the assumption that the inconsistency in II i 98 and II 4 of the authentic texts is the result of imperfect revision; and as we have seen there is no proof of this and it may be a simple Shakespearian inconsistency. The second and third explanations are not essentially different: we shall find in chapter viII that although the Brudermord as a whole is certainly not based on the QI text, it is indebted to it in certain places. But it is immaterial whether the change of sequence was made when the QI text was compiled, and then reproduced when the Brudermord text-basis ${ }^{I}$ was compiled, or whether the change was made in a version (subsequent to the $\mathrm{Q}_{2}$ text) on which in this respect both the QI text and the Brudermord text-basis were independently founded. In either case both texts here represent the same altered version -and we may well say the same altered stage-version.

I I say "text-basis" because the extant text of the Brudermord, going back only to a manuscript of 17 ro, probably does not faithfully represent the text originally taken to Germany by English actors. It has been debased. 


\section{THE NAME "CORAMBIS".}

Throughout QI the name "Corambis" is found instead of "Polonius". In the scene corresponding to II i I $\rightarrow$ I the name "Montano" is found for the "Reynaldo" of the authentic editions. In Der Bestrafte Brudermord the counsellor is called Corambus; Montano-Reynaldo does not appear. The name "Corambus" occurs in All's $W_{\text {ell }}$ that Ends $W$ ell, and it seems highly probable that the suffix "-is" of QI is an error.

Critics who maintain that QI owes nothing to any version of the play prior to that given in $Q_{2}$ are placed in a difficult position by these two names, Corambis and Montano. Gustav Tanger ${ }^{\mathrm{I}}$ states that the name Polonius occurs only four times in the received text: actually it occurs five times. ${ }^{2}$ Tanger suggests that at each of these points the reporter, taking notes in the theatre, missed what was spoken on the stage. He either omitted the sentences containing the name Polonius, or, having only brief disconnected notes, wrote them up "rather independently":

...X [i.e. the reporter], in the hurry of taking down his notes, failed to hear the name of Polonius distinctly enough to note it down in its correct form. If we consider that to X, Polonius must have seemed a subordinate character as compared with Hamlet, Ophelia, the King, the Queen, and Horatio, and that we meet with partial distortions in the names of Gilderstone, Rossencraft, Voltemar, and Cornelia, and Leartes; that the name of Ostrick, - (which occurs twice in the text of $Q_{2}$ (v ii I 96 and 257) and once only in that of $\mathrm{F}_{\mathrm{I}}$, the former passage (the dialogue with the Lord) not being represented on the stage,)-is entirely wanting in $\mathrm{QI}$; that in like manner the name of Francisco, which also occurs only once in the opening of the piece, has not been caught

I Transactions of the New Shakspere Society, I880-2, Part I, pp. I 5 6-9:

${ }^{2}$ I ii 57 ; IV i 34 ; IV iii 16 and 3 r ; IV v 82 . 
by $\mathrm{X}$, we may safely infer that Corambis is nothing but a distortion of the true name of Polonius. And indeed at some distance from the stage, $\mathrm{X}$ could easily misunderstand Corambis for Polonius, especially as he was busy taking down his notes. Observe that both words are trisyllabic, that both have an "o" in the first syllable, followed by a liquid consonant, that both accent the second syllable containing a nasal consonant, and that both names have an "s" for their final consonant. ${ }^{\mathrm{I}}$

Quite apart from the firm belief that we have to deal not with a stenographer in the theatre but with memorial reconstruction, I find this completely unconvincing. I cannot see how it could be suggested that "Corambis" or "Corambus" is a mishearing of "Polonius". Despite the phonetic similarities noted by Tanger the two words sound entirely different. He has convinced no one: indeed, the suggestion is patently nonsensical. He would have done much better to advance a solution such as that of Dr B. A. P. Van Dam, who suggests exactly similar circumstances but who avoids the absurdity of Tanger's theory of mishearing. "We know", says Dr Van Dam, "how difficult it sometimes is to catch a name unknown to us which is only pronounced a few times upon the stage; it is thus quite possible that the reporter did not understand the name Polonius and left a blank in his stenograph. QI could not be sent to the printer without a name for the player of the part of Polonius; a name had to be found, and, as Sir Israel Gollancz says, 'the old popular name Corambis' was found perfectly suitable." Advocates of the theory of memorial reconstruction, however, will find difficulty in readily supposing that an actor who had taken part repeatedly in performances of the full play could be totally ignorant of the name of one of the principal characters. If the names Polonius and

I Op. cit. pp. I $57-8$.

2 The Text of Shakespeare's "Hamlet", p. 45. 
Reynaldo are indeed earlier than Corambis and Montano, it would seem more reasonable to suppose that in the memorial reconstruction the change was made deliberately.

Creizenach, maintaining the complete dependence of the $Q_{1}$ text upon that of $Q_{2}$, put forward the suggestion that the names Polonius and Reynaldo contained allusions to definite personages (presumably personages of importance), and that the players did not dare to use the names on the stage, altering them instead to Corambis and Montano. ${ }^{\mathrm{I}}$ Creizenach simply throws this out as a conjecture, admitting the impossibility of being more specific.

Sir Edmund Chambers also holds that Polonius and Reynaldo were the original names, and that they were altered in an acting-version which underlies Q1. ${ }^{2}$ This theory of Creizenach and Chambers involves at least one difficulty, inasmuch as the names in FI (printed from a transcript of the Globe prompt-copy ${ }^{3}$ ) are those which they regard as the earlier. If the alteration were made only in a provincial acting-copy, underlying $\mathrm{Q}_{\mathrm{I}}$, we should be compelled to enquire why a country company should be afraid to use names which a London company did not scruple to employ. If on the other hand the change of names was made in the official acting-version and in the performances of Shakespeare's company itself, we must suppose that at some time prior to 1623 the company reverted to the original names. This seems a rather cumbersome hypothesis. It would be much easier to suppose that the alteration was the other way about and that the names

I Shakespeare Fahrbuch, vol. xLII (1906), p. 84. "Man könnte wohl vermuten, dass in den Namensformen Polonius und Reynaldo Anspielungen auf bestimmte Persönlichkeiten enthalten sind, und dass die Schauspieler deshalb es nicht wagten, diese Namen auf der Bühne auszusprechen, etwas sicheres lässt sich über die Ursache des Namenswechsels jetzt nicht mehr sagen."

2 William Shakespeare, vol. I, pp. 417-8.

3 See J. Dover Wilson, Manuscript of Shakespeare's "Hamlet", vol. I, pp. 22 ff. 
Corambis and Montano existed in a version of the play anterior to that of $Q_{2}$. Furthermore, we have already discovered in the QI text isolated traces of such a version.

Throughout $Q_{I}$ the speeches of Corambis (and also those of Montano, who appears only in scene $v$ lines $\mathrm{I}-3 \mathrm{I}$ ) are quite close to those in the accredited editions. There are no discrepancies which cannot be accounted for as perversions made in the course of imperfect memorial transmission. Thus if there was a Shakespearian revision between the text published in $Q_{1}$ and that of $Q_{2}$, it involved, as far as these characters are concerned, only a change of names, and no textual alteration. Furnivall suggested that in revising his first draft Shakespeare made the change simply because he "fancied one pair of names better than the other". ${ }^{\text {I It }}$ is possible, however, that here the compiler of QI, reproducing as best he could the text of Shakespeare $\left(\mathrm{Q}_{2}\right)$, reverted for some obscure reason to the names of the old Hamlet.

An important contribution to this discussion is that of Sir Israel Gollancz, ${ }^{2}$ who suggested that the name Corambus was the creation of the author of the pre-Shakespearian Hamlet, and who proposed a derivation for it. The Latin word "crambe" (borrowed from Greek) signified a kind of cabbage, and there was a proverbial expression "crambe repetita", meaning "cabbage warmed up again", i.e. something repeated, an old story, tedious and unpleasant iteration. ${ }^{3}$ A popular variant of "crambe" was "Crambo"; and "Corambe" and variants are found in Latin-English dictionaries of the sixteenth century. Thus " Corambis'

I Introduction to Griggs' facsimile of $Q_{2}$ Hamlet, p. xi.

2 A Book of Homage to Shakespeare (1916), pp. 173-7; see also Proceedings of the British Academy, 1903-4-summary of a paper on "Shakespeariana, 1598-1602" delivered by Gollancz, April 27, I904.

3 Cf. "Occidit miseros crambe repetita magistros", Juvenal, Satire VII, I54. 
or 'Corambus", says Gollancz,', "was merely, as it were, 'old Crambo', an excellent name for the inherent characteristics of the Counsellor, who in the original of the story, as told by Saxo Grammaticus in the Danish History, had exalted ideas of his own profound astuteness, for which he paid the heavy penalty." Gollancz goes on to suggest that "the possibilities of the character were effectively developed by the earlier dramatist", and that possibly "the character was so set forth as to portray some marked characteristics of Elizabeth's aged counsellor, the great statesman Burleigh, for whom contemporary men of letters had but scant reverence". Burleigh died in 1598 , and his son Robert Cecil became one of the most important men in England. "We may certainly assume", says Gollancz, "that the change of the name from 'Corambis' to 'Polonius' was made by Shakespeare soon after I 598 when he was still transforming the older play; and that he was anxious to make it clear that his Counsellor... was not to be associated in the public mind with the earlier caricature of the great statesman who had gone to rest." 2

Here, then, is a not unreasonable conjecture: in the old play Corambus is drawn as a caricature of Burleigh; Shakespeare, writing his play sometime after Burleigh's

${ }^{x}$ Book of Homage, p. 173 .

2 Book of Homage, p. 174. Gollancz also suggests a derivation for the name Polonius. He refers to a manual for counsellors, popular in England at the end of the sixteenth century, by the great Polish statesman Laurentius Grimalius Goslicius, Bishop of Posen (published in Venice in 1568 ). An English version appeared in 1598 , the year of Burleigh's death. On the title-page it is "consecrated to the honour of the Polonian Empire". "We may feel sure", says Gollancz (op. cit. p. I75), "that it was this translation that Shakespeare looked into, and, to the honour of the 'Polonian' name, dubbed the counsellor of the King of Denmark by a name which could only mean the Polonian, or the Pole." Gollancz produces evidence of the popularity of the work in England, and points in it to suggestive parallels to the words and character of Polonius and to the speech "What a piece of work is a man". 
death, very properly alters the name, substituting another which also had some topical significance. But probably the character in the old play was a popular one: and in the acting-version underlying $Q_{I^{I}}{ }^{I}$ the players reverted to the old popular name in order to curry favour with their audiences (in the provinces?), but retained the full Shakespearian text as far as memory would permit. $^{2}$ It is all extremely hazardous; but some explanation must be found, and we have little or no evidence upon which to go.

As an alternative to the above (but not, I think, quite so likely) I would mention a most interesting suggestion made by Professor H. D. Gray in a short study of the rôles sustained by the actor William Kemp. ${ }^{3}$ Professor Gray points out that Kemp had begun his career with such "merriments" as are advertized on the title-page of A Knack to Know a Knave. 4 This play contains little scope for a comedian in the dialogue, and probably Kemp relied on his facility for improvisation. We know that one of his favourite tricks was to take off his slipper and throw it at some other member of the cast. We also know from a stage-direction in $\mathrm{Q}_{2}$ Romeo and Fuliet 5 that he took the part of Peter in that play: here there are opportunities for clowning in the scene with the musicians ( $\mathrm{IV} \mathrm{v} \mathrm{IO} 3 \mathrm{ff}$.), and for mimicry and by-play when Peter is attending the

I And also the Brudermord. See Chapter virr.

2 Cf. Gollancz, Book of Homage, p. 174: he suggests that possibly "the old popular name 'Corambis' was attached to the character, instead of Polonius, by the unauthorized purloiners answerable for the publication of the First Quarto".

3 Modern Language Review, vol. xxv (1930), pp. 261-73.

4 "A most pleasant and/merie nevv Comedie,/Intituled,/A Knacke to knowe a Knaue./Newlie set foorth, as it hath sundrie/tymes bene played by Ed. Allen/and his Companie./VVith Kemps applauded Merrimentes/of the men of Goteham, in receiuing/the King into Goteham./(Device.)/Imprinted at London by Richard Iones, dwelling/ at the signe of the Rose and Crowne, nere/Holborne bridge, ${ }_{5} 594$.

5 At the top of sig. $\mathrm{K}_{3} \mathrm{v}$ the S.D. reads "Enter Will Kemp", and Peter enters. 
Nurse. But later we find Kemp taking the part of Dogberry in Much Ado About Nothing. ${ }^{\mathrm{P}}$ His art must have developed in an extraordinary fashion meanwhile. Dogberry is no clown who throws slippers about. Professor Gray suggests that by this time Kemp was the principal "character-actor" in Shakespeare's company rather than a mere clown. And he would assign to him the part of Corambus in Hamlet.

There is evidence that Kemp left the company in I 599, possibly as the result of a quarrel of some sort. ${ }^{2}$ Suppose that in a Hamlet prior to that date he had played the part of Corambus so effectively that the actor had become identified in the public mind with the character: suppose that to the average audience Corambus was William Kemp. Then Kemp leaves the company. Would it not be advisable for Shakespeare to change the name of the character in his play? Audiences might resent the imposition upon them of a Corambus who was not Kemp: but if the name was altered there would be less ground for complaint-at least they would not have been lured to the theatre on false pretences. In writing the version underlying $\mathrm{Q}_{2}$ Shakespeare might have been influenced by such considerations: but the person responsible for concocting the QI text might, nevertheless, have decided to revert to the old popular names.

I cannot see that it is possible to leave this problem in any other than a profoundly unsatisfactory state. Explanations for the difference in names may be found to accord with any general hypothesis of the relationship to each other of the extant Hamlet texts. One might, however, mention Montano again in conclusion. He has a very small part indeed, and we could readily suppose that a memorial reconstructor simply forgot the name and supplied another of his own choosing. And this may have been so. At the same time, it is remarkable that the only

${ }^{x}$ See Introduction, pp. 7-8.

2 See $\$$ vII of the present Chapter. 
appearance of this character is in a scene in which the counsellor is also involved. It certainly looks as if the considerations which led to the alteration of the counsellor's name also demanded the alteration of his servant's name. Was Montano originally a pen-portrait of a friend or servant of Burleigh, and was his name changed by Shakespeare to break the association just as in the case of the statesman himself? Or was the part at one time associated with an apprentice-actor attached to Kemp, who left the company along with him, the change being made for the same reason as the other? It is quite impossible to say. But whatever the reason for the double alteration, Shakespeare used both of the rejected names again-Corambus in All's Well (IV iii I 85), Montano in Othello. The trouble in Hamlet, then, may have been the names as attached to certain characters: attached to quite other characters they were apparently acceptable.

I confess to being tolerably certain of only one thingthat the speeches of Corambis and Montano are based on those of the corresponding characters in $\mathrm{Q}_{2}$ and $\mathrm{F}_{\mathrm{I}}$, and that the names, and these only, may have their foundation in an earlier version of the play. And inasmuch as the $\mathrm{Q}_{\mathrm{I}}$ reporter may simply have attached the names of the old play to his version of the text of Shakespeare, it may not be necessary to enquire how a change of names could be of any use without a change of character as well. ${ }^{\mathrm{X}}$

\section{HAMLET'S AGE}

$\mathrm{Mr}$ R. Crompton Rhodes, calling attention to chronological differences in the graveyard scene between $Q_{1}$ on the one hand and $Q_{2}$ and $F_{I}$ on the other, expresses the opinion that QI represents an acting-version (post-dating the $\mathrm{Q}_{2}$ text) in which Hamlet's age had been altered so that the part might be played by a youthful actor. ${ }^{2}$

${ }^{2}$ Cf. Chambers, William Shakespeare, vol. I, p. 418 .

2 Shakespeare's First Folio (1923), pp. 79-80. 
In $\mathrm{Q}_{2}$ the facts given are these:

Ham. How long hast thou been grave-maker?

I Clown. Of all the days i'th'year I came to't that day that our last king Hamlet overcame Fortinbras.

Ham. How long is that since?

I Clown. Cannot you tell that? every fool can tell that. It was that very day that young Hamlet was born: he that is $\mathrm{mad}$ and sent into England.

Then, later,

I Clown. ...I I have been sexton here man and boy thirty years. And

I Clown. ...Here's a skull now: this skull hath lien you i'th'earth three-and-twenty years... this same skull, sir, was, sir, Yorick's skull....

According to all this very exact information, Hamlet was seven years old when Yorick died, and he is now thirty. I would, however, stress a point which $\mathrm{Mr}$ Crompton Rhodes does not mention: if we insist on making this mathematical calculation, we find that young Fortinbras must be at least thirty years old at the time of the action of the play, since his father had been killed thirty years before. That he was killed is explicitly stated in Horatio's narrative of the same combat as that to which the Clown refers:

...the combat; in which our valiant Hamlet

(For so this side of our known world esteemed him)

Did slay this Fortinbras.

This point is significant, as we shall see.

Turning to the QI version of the graveyard scene, we are given the following information by the Clown:

Looke you, heres a scull hath bin here this dozen yeare,

Let me see, I euer since our last king Hamlet

Slew Fortenbrasse in combat, yong Hamlets father,

Hee that's mad.

(xvi 85-8) 
In QI, then, Yorick has been dead for about twelve years (for the word "dozen" may simply be used as an approximation). In calculating Hamlet's age from the QI data, $\mathrm{Mr}$ Crompton Rhodes takes one detail from $\mathrm{Q}_{2}$, viz. that Hamlet was seven years old when Yorick died. By adding these seven years to the dozen that have passed since the jester's death, he concludes that in the version of 1603 Hamlet was a youth of nineteen. But the fact that Hamlet was seven when Yorick died is deduced from the dating of the combat and of Yorick's death in $\mathrm{Q}_{2}$ (respectively thirty and twenty-three years before the action of the play): and these dates are different in QI, which gives us no information as to Hamlet's age at the decease of Yorick. We know from QI that he was alive when Yorick died, since according to that text also the latter had carried him on his back (xvi 107). All that we are told in the Q1 graveyard scene is that the elder Fortinbras was killed a dozen years before the supposed date of the action, and that the younger Fortinbras, and also Hamlet, must be over twelve. It is therefore possible, according to the QI chronology, to regard young Fortinbras and Hamlet as just arrived at manhood.

Now consider the character of young Fortinbras in $\mathrm{Q}_{2}$ and FI. If we turn back to Horatio's narrative in the first Act (r i $80 \mathrm{ff}$.), we cannot avoid believing that Fortinbras has made the avenging of his father and the reclaiming of his lost dominions the first task of his manhood. He is "young Fortinbras,/Of unimproved mettle hot and full"; he has the support of a band of "lawless resolutes". The picture is indubitably one of an impulsive youth, burning for revenge, and aided by a "list" of reckless young adventurers. It would be totally inconsistent with this characterization to suppose that he would deliberately wait until he was thirty before embarking on his ardent bid for vengeance and re-instatement. Yet we must make this supposition if we claim the right to deduce 
Hamlet's age from the figures given in the graveyard scene in $\mathrm{Q}_{2}$ and $\mathrm{F}_{\mathrm{I}}$, as $\mathrm{Mr}$ Crompton Rhodes does. Clearly it is the figures given in the QI version of that scene which are consistent with Shakespeare's own drawing of the character of young Fortinbras. Nor is there anything in $\mathrm{Q}_{2}$ or $\mathrm{F}_{1}$ (apart from this scene) which precludes the possibility of regarding Hamlet as quite a young man: on the contrary, there is much that positively suggests it.

If we give full weight to the "evidence" of the graveyard scene in the different texts, then we find that we have two distinct chronologies, one of which is consistent with the remainder of the full play, the other of which is not. Under these circumstances we are, I think, almost bound to conclude that the former was the original chronology, while the latter represents an alteration made at one point for a particular reason. If Shakespeare, in the $\mathrm{Q}_{2}$ version, meant us to accept the Clown's evidence that Hamlet was thirty years old, it must surely be clear that he has altered the conception of Hamlet from that of a youthful figure to that of a mature man. That is to say, the chronology given in the QI version of the graveyard scene is consistent with an earlier characterization of the hero, not a later one as $\mathrm{Mr}$ Crompton Rhodes suggests.

Finally, however, there is more than a little doubt that Shakespeare ever meant us to take literally the figures given by the gravedigger in $\mathrm{Q}_{2}$ and $\mathrm{F}_{\mathrm{I}}$. This point is made by Hr. V. Østerberg in a brilliant little pamphlet entitled Prince Hamlet's Age. ${ }^{\mathrm{I}} \mathrm{He}$ reminds us that "an author does not make himself responsible for the correctness of the words he puts into the mouths of his characters. They may make mistakes, lie, blaspheme, boast, indulge in set phrases, etc., according to their several natures and, as it were, at their own risk.... Who says that the Clown was meant to speak the objective truth in boasting of his thirty 
years' sextonship? Why may we not as well suppose that the phrase was intended by the author as a humorous and palpable exaggeration on the Clown's part?"I I believe that there is a good deal in this, and that we should not make too much of the exactness of the Clown's information in Q2. After all, had Shakespeare intended to force Hamlet's age upon our attention, he would surely have done so more effectively. No audience would make the computation necessary to discover the hero's age from the data supplied by the Clown, and in any case the alleged information is given far too late in the play to be of any dramatic utility. As an alternative to Hr. $\varnothing$ sterberg's suggestion we might suppose that Shakespeare, putting a list of numerals into the mouth of the Clown, simply made a mistake or two-giving some which by diligent search can be found to conflict with other things in the play, but which the average audience would not notice. As for QI, with so much room for bungling and failure of memory, it would be foolhardy to over-emphasize any detail contained in it. The final point is, however, that there is no foundation for Mr Crompton Rhodes's theory of the alteration of $\mathrm{Q}_{2}$ for performance by a young principal actor; on the contrary, he can be controverted on his own ground.

VII. HAMLET'S DIRECTIONS TO THE PLAYERS: THE CLOWN

We could hardly have expected to be able to leave the first Quarto of Hamlet without encountering one or more apparently insoluble problems. One of the most tantalizing of these is provided by the passage in which Hamlet speaks to the Players about pitfalls to be avoided by their Clown. The passage runs as follows (QI ix 26-44):

I Op. cit. p. I9. 
Ham. And doe you heare? let not your Clowne speake

More then is set downe, there be of them I can tell you

That will laugh themselues, to set on some

Quantitie of barren spectators to laugh with them,

Albeit there is some necessary point in the Play

Then to be obserued: $\mathrm{O}$ t'is vile, and shewes

A pittifull ambition in the foole that vseth it.

And then you haue some agen, that keepes one sute

Of ieasts, as a man is knowne by one sute of

Apparell, and Gentlemen quotes his ieasts downe

In their tables, before they come to the play, as thus:

Cannot you stay till I eate my porrige? and, you owe me

A quarters wages: and, my coate wants a cullison:

And, your beere is sowre: and, blabbering with his lips,

And thus keeping in his cinkapase of ieasts,

When, God knows, the warme Clowne cannot make a iest

Vnlesse by chance, as the blinde man catcheth a hare:

Maisters tell him of it.

Players. We will my Lord.

Lines $I-7$ are directly based upon III ii $37-43$ in the "good" texts, which, however, contain absolutely nothing corresponding to the remainder of the speech quoted. Where then did this come from? Answers have been given in accordance with all general hypotheses advanced for the QI text as a whole, and direct evidence pointing in itself to a positive conclusion is wanting.

Professor Dover Wilson has found sources for two of the vapid jokes peculiar to the QI version. ${ }^{\text {I }}$ In Tarlton's Fest-Book, published in $16 \mathrm{I} \mathrm{I}^{2}$ there occur two anecdotes containing similar witticisms. In one of these Tarlton "counterfaited a drunkard" for the Queen's entertainment, and called for beer, which was brought to him. But "Her Majestie, noting his humor, commanded that he

I The Library, 1918, pp. 240-1.

2 There may have been an earlier edition; see Chambers, Elizabethan Stage, vol. II, p. 344 . 
should have no more; for, quoth shee, he will play the beast, and so shame himselfe. Feare not you, quoth Tarlton, for your beere is small enough."I In the other Tarlton was in an eating-house, and on his left was an important gentleman with a very red face. Tarlton "presently in great haste called his host, Who doe I serve, my host, quoth Tarlton. The Queenes Majestie, replied the good man of the house. How happens it then, quoth Tarlton, that to her Majesties disgrace, you dare make me a companion with servingmen, clapping my Lord Shandoyes cullisance upon my sleeve, looking at the gentleman with the red face." ${ }^{2}$ Here, then, are two feeble jests attributed to Tarlton (who died in 1 588) and carrying a certain mild resemblance to two of those found in the passage peculiar to QI which we are examining.

In his directions to the players in both "bad" and "good" versions Hamlet has in mind the forthcoming performance of the Gonzago play. But there is no clown in that play. It is quite clear, then, that in putting these strictures on the Clown into Hamlet's mouth Shakespeare must be expressing his own views, presumably with a real clown or clowns in mind. Arguing that the $Q_{1}$ text depended basically upon an abridged transcript of the old Hamlet only partially revised by Shakespeare, Professor Dover Wilson dated this passage to before 1588 , and regarded it as an attack on Tarlton himself. ${ }^{3}$ Not only is his general hypothesis invalid, however: I very much doubt whether in any case we could comfortably assume that Shakespeare was indebted to the old play for the fact that Hamlet issues advice to the players before the performance of the "Mouse-trap". In general, the Dover Wilson hypothesis shares with that of the Clarendon editors the disadvantage of postulating in Shakespeare a quite slavish

I Tarlton's Fests, ed. Halliwell (Shakespeare Society, I844), p. 5 .

${ }^{2}$ Ibid. p. I2.

3 The Library, 1918, p. $24 \mathrm{r}$. 
dependence on the old Hamlet after the earlier scenes. ${ }^{\mathrm{I}}$ It is much more likely that the writer of this passage in QI was satirizing a clown or clowns who, after Tarlton's death, still repeated his jokes and no others. He is in fact castigating the Tarlton tradition which had become outworn in the hands of his successors. ${ }^{2}$

Is the passage Shakespearian or not? Furnivall is quite emphatic: "whose but Shakespeare's is the 'cinkapase of ieasts', etc.?"3 On the assumption that the lines we are considering were part of Shakespeare's first draft, and that he excised them later, Brinsley Nicholson would identify the objectionable clown with William Kemp, who is known to have been absent from Shakespeare's company between 1599 and 1602.4 This suggestion is so interesting that it must be carefully considered.

Nicholson calls attention to the following facts: (I) Kemp played in Every Man in his Humour in 1598 but not in Every Man out of his Humour in I 599; (2) he performed his morris-dance to Norwich in I 599; (3) in his account of this escapade (the Nine Days' Wonder), entered in the Stationers' Register on 22 April 1600, he warns the public to take no notice of rumours of his having gone abroad: "it is improbable that these would have arisen," says Nicholson, "had he been still playing and likely to play with his company"; (4) despite the warnings referred to, he announces at the end of the Nine Days' $W$ onder that he is about to go abroad; (5) in The Return from Parnassus, performed in I602, he is twice saluted as having come from the continent; (6) in the same play Kemp and

I See pp. I32-3.

2 Nicholson suggests that Yorick is Tarlton (see reference in note 4). This is not necessarily the case; but if so, Shakespeare apparently remembered Tarlton affectionately. But there is no necessary inconsistency, since he is here depreciating his posthumous imitators.

3 Griggs' facsimile of QI, p. vii.

4 Transactions of the New Shakspere Society, I880-2, Part I, pp. $57 \mathrm{ff}$. 
Burbadge are represented as going to Cambridge together in search of recruits- "a thing almost impossible if they belonged to rival companies", says Nicholson, "and wholly impossible if we read the scene" (Iv iii). There is evidence, then, that Kemp was absent from Shakespeare's company between 1599 and 1602 , in which latter year, according to Nicholson, he rejoined it.

Now Nicholson suggests that the reason for Kemp's departure was a quarrel between him and the other members, including Shakespeare. He argues that Shakespeare, angry with $\mathrm{Kemp}$, satirized him in his first draft of Hamlet, but reduced the passage in question when $\mathrm{Kemp}$ returned to the company (presumably with a reconciliation effected). This is admittedly a pretty theory, but I would say two things. First, even if we accepted it outright it is no evidence for what could be termed a Shakespearian revision of a first sketch: it is simply an isolated cancellation of a few lines. But secondly, even allowing a Shakespearian cancellation here, he has nevertheless retained part of the attack upon the clown-he has retained the complaint about improvisation. The clown is still satirized in $\mathrm{Q}_{2}$ and Fi. Can the feeble jests which, in Nicholson's view, Shakespeare expunged have really represented in 1602 the hall-mark of the man for whom the part of Dogberry had been specially written ${ }^{1}$ about $1598-9,{ }^{2}$ to such an extent that their excision made all the difference between a contemporary audience recognizing or not recognizing him? Surely not. If there is indeed an allusion to Kemp here in $Q_{1}$, then there would seem to be the remnant of an

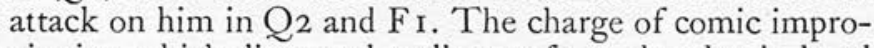
visation which distracted audiences from the play in hand was not one to which Kemp could have pleaded guiltless in the earlier years of his career-though we may doubt whether he maintained this habit later, when, for example,

I See pp. 7-8.

2 See Chambers, William Shakespeare, vol. I, p. 270. 
he played Dogberry. But in any case can we suppose that after his return to the company in 1602 such an attack would continue to be made from the stage, so that it appears in the Folio, printed from a transcript of the prompt-book? We may doubt whether Kemp lies behind the attack on the clown in either QI or Q2: it is quite possible that in both cases it is simply prevalent stage practices which are satirized.

If we confine our attention to the dozen lines peculiar to QI, we must remember the distinct possibility that they are, as Sir Edmund Chambers believes, ${ }^{\mathrm{X}}$ a theatrical interpolation. He says that the witticisms, two of which resemble jokes in Tarlton's Fest-Book, "were doubtless traditional, and their introduction here of the nature of 'gag"," The clown or clowns referred to are simply accused of repeating stale jests again and again: it is quite possible that the reporter simply added a passage of his own to what was essentially a report of the text of $Q_{2}$. As for the alleged Shakespearian tone of the passage, it hardly suggests his best manner and it is certainly not beyond the imitative powers of the reporter who reproduced the rest of the advice to the players. Alternatively, if the QI text was used for acting in the provinces, like that of Orlando Furioso, the passage may have been added to it at some time during its provincial stage-history.

In the last resort we are left with nothing surer than a balance of probabilities: the passage may have been struck out of Shakespeare's play before the appearance of the $\mathrm{Q}_{2}$ text, or it may have been inserted into that of $Q r{ }^{2}$ The

I William Shakespeare, vol. I, pp. 418-19.

${ }^{2}$ Two of the passages found in FI but not in $Q_{2}$ may have been cut out deliberately when $Q_{2}$ was printed, viz. II ii $242-72$ and $340-65$. And $F_{I}$ gives an abridged version of the play. Thus the $Q_{I}$ passage with which we are concerned may represent a passage cut in both $\mathrm{Q}_{2}$ and $\mathrm{F}_{\mathrm{I}}$. But its fairly poor quality conduces somewhat to the other theory. 


\section{QI: THE CLOWN}

latter hypothesis is at least as probable as the former. And even the former postulates no more than a simple cancellation; we have found no clear evidence in QI for the existence behind it of anything that might be called a Shakespearian first draft, and this passage does not entail that general conclusion. 


\section{DER BESTRAFTE BRUDERMORD}

The text of this German version of Hamlet is known to us only from a manuscript, now lost, which bore the date "den 27. Oktober 1710 ". Extracts from this manuscript were published in the Theater-Kalender auf das $7 \mathrm{ahr}$ I779 (Gotha), pp. 47-60; and in 178 I H. A. O. Reichard, the editor of the Theater-Kalender, published the full text in his periodical Olla Potrida (Berlin); in which it occupies pp. 18-68 of Part II of the volume for that year. The manuscript being lost, it is upon this reprint that we rely as the earliest extant text of the German play.

There is not the slightest doubt that Der Bestrafte Brudermord represents an English play, carried over to Germany by English travelling actors about the end of the sixteenth or the beginning of the seventeenth century. We know that English actors went to Germany as early as 1586; ${ }^{\mathrm{I}}$ and we know that a play called Tragoedia von Hamlet einen Printzen in Dennemark was performed by English actors at Dresden in $1626 .^{2}$ Furthermore, an examination of the German text shows that it stands in close relationship to Shakespeare's Hamlet as contained in Q2, though a definition of the exact nature of this relationship is extremely difficult. It is clear that while the text of the Brudermord represents an original of the late sixteenth or early seventeenth century, the fact that our earliest text is of 1710 leaves room for a century or so of alteration in the German stage-history of the play. It is not at all likely that the text which we possess is a faithful

I See Albert Cohn, Shakespeare in Germany (1865), pp. xxiiff.

2 See E. K. Chambers, Elizabethan Stage, vol. II, p. 286, and William Shakespeare, vol. I, p. 422. 
reproduction of the text which the English players carried to the continent, however they had come by that.

One of the most notable characteristics of the Brudermord is that, while it contains many features peculiar to itself among Hamlet texts, it also contains parallels with $\mathrm{Q}_{2}$ and $\mathrm{F}_{\mathrm{I}}$ where $\mathrm{Q}_{\mathrm{I}}$ disagrees, and parallels with $\mathrm{Q}_{\mathrm{I}}$ where $\mathrm{Q}_{2}$ and.FI disagree. This was pointed out by Creizenach, ${ }^{\mathrm{I}}$ who elaborated an ingenious hypothesis to explain these circumstances. He argued that the Brudermord was based upon a stage-version of the $Q_{2}$ text, and that this stage-version contained certain alterations, some of which also appear in the pirated text of Qr. Gustav Tanger disagreed. ${ }^{2}$ He thought that the Brudermord was founded upon the QI text itself, and he tried, not very successfully, to brush aside Creizenach's imposing list of instances in which the German text agrees with the second Quarto against the first. Where he was compelled to admit the force of a parallel with $Q_{2}$, he explained it as a subsequent infiltration from the full Shakespearian play.

Here, then, we have two hypotheses. A third is presented by John Corbin, Ashley H. Thorndike, M. Blakemore Evans, and Charlton M. Lewis, ${ }^{3}$ who argue that the German text is based upon the so-called Ur-Hamlet. This involves the corollary assumption that the first Quarto represents Shakespeare's first revision of the play

I See Berichte über die Verhandlungen der königlich-sächsischen Gesellschaft der Wissenschaften zu Leipzig: Philologisch-Historische Classe, 1887 , pp. 1-43. Also Die Schauspiele der englischen Komödianten (1889), introduction, pp. 127-45; and Modern Philology, vol. II (1904-5), pp. 249-60.

2 Shakespeare Fahrbuch, vol. XxIII (1888), pp. 224-45.

3 See Corbin, Harvard Studies and Notes in Philology and Literature, vol. v (1896), pp. 245-60; Thorndike, Publications of the Modern Language Association of America, vol. XVII (1902), pp. I2 5 ff.; Evans, Modern Philology, vol. II (1904-5), pp. 433-49; Lewis, The Genesis of Hamlet (1907). The theory was first presented by R. G. Latham in his Two Dissertations on the Hamlet of Saxo Grammaticus and of Shakespeare (1872). 
and the second his final version. Then, where the Brudermord agrees with $\mathrm{Q}_{\mathrm{I}}$ against $\mathrm{Q}_{2}$, it is easy to assume that it presents features of the Ur-Hamlet retained by Shakespeare in his first sketch but altered by him in revision: and where the German text agrees with $Q_{2}$ against $Q_{1}$ it is assumed that it presents features of the old play preserved by Shakespeare in both his first draft and his final version, features which are, however, omitted or altered by the person or persons who pirated his first draft (for $Q_{I}$ is unquestionably a reported text).

These are the principal hypotheses in the field, along with that represented by Sir Edmund Chambers, who holds that the Brudermord is derived from the full Shakespearian text. ${ }^{\mathrm{I}}$ This theory, and that of Creizenach, neither of which explain every difficulty, have nevertheless the great merit of taking into account the frequency of agreement between the Brudermord and the texts of $Q_{2}$ and $F_{I}$. In reopening the discussion it will be impossible to indicate the whole extent of this agreement. I shall simply set out a number of cases where the German text agrees with the accredited Shakespearian texts against that of Q1. In considering the list which follows it is important to remember that in all probability the text which the English actors took to Germany was itself a memorial reconstruction of some sort: accordingly, there may be cases of parallel phrases in different positions. Again, there is room for the slight divergence of originally identical phrases in translation. Nevertheless, there are definite parallels, the most striking of which follow: ${ }^{2}$

(I) In B.B. I iv 36-7 Hamlet, having been told that it is midnight, says "Eben recht, denn um dieselbe Zeit

I See William Shakespeare, vol. I, p. 4r2.

2 Needless to say many of these parallels have been pointed out before, notably by Creizenach. In the list I have used the abbreviation "B.B." to signify the Brudermord. References to it are to the reprint in Cohn's Shakespeare in Germany. 
pflegen sich die Geister sehn zu lassen, wenn sie wandeln". In the authentic Shakespearian texts, at exactly the same point, Horatio says "it then draws near the season,/ Wherein the spirit held his wont to walk" ( $\mathrm{r}$ iv 5-6). The statement is general in B.B., particular in Shakespeare; but the passages clearly correspond, and there is nothing similar in QI.

(2) In B.B. I v I6-1 8 the Ghost says to Hamlet " . . . die Zeit kommt bald, dass ich mich wieder an denselben Ort begeben muss, wo ich hergekommen". This instantly recalls I v 2-4 in the accredited Shakespearian texts, where the Ghost says "My hour is almost come,/When I to sulph'rous and tormenting flames/Must render up myself" - a passage not represented in Qr.

(3) The opening of I vii in B.B. is very close to the beginning of $\mathrm{r}$ ii in the full Shakespearian texts (lines II6); QI entirely omits this passage. The closest verbal parallels are: (i) B.B. "Obgleich unsers Herrn Bruders Tod noch in frischem Gedächtnis... ist", Q2 "Though yet of Hamlet our dear brother's death/The memory be green": (ii) B.B. "und uns gebietet...", $Q_{2}$ "and... it us befitted".

(4) After the meeting between Hamlet and Ophelia, the King says (B.B. II iv 29) "uns dünkt aber, dass es keine rechte Tollheit, sondern vielmehr eine simulirte Tollheit sey". This directly corresponds to III i I 66-7 in the authentic Shakespearian texts, where Claudius's verdict is that "what he spake, though it lacked form a little,/Was not like madness". The corresponding passage in QI (vii $\mathrm{I}-2$ ) has nothing of this.

(5) Again, in the same speech in B.B. the King says "es möchte. . w was Uebels daraus entstehen". This corresponds to the words "And I do doubt the hatch and the disclose/Will be some danger" (IIr i I69-70 in the genuine Shakespearian texts), again unrepresented in the $Q$ I version. It must be remembered that we are concerned not only 
with exact verbal parallels, but also with passages which correspond in B.B. and $Q_{2}$ and which are totally wanting in QI.

(6) In B.B. II vii 62 Hamlet, speaking of the Players' art, says "man kann in einem Spiegel seine Flecken sehen". This parallels III ii $2 \mathrm{I}$ in the authorized texts, where Hamlet declares that the purpose of the drama is "to hold as 'twere the mirror up to nature". The mirror is not mentioned in QI.

(7) In B.B. In vii I I 4 Hamlet refers to the King as "mein Vater und Vetter". Compare, in the authentic Shakespearian texts, "my uncle-father" (II ii 379). There is nothing corresponding to this appellation in QI.

(8) Just before the entry of the Court to see the play Hamlet says to Horatio "ich werde simuliren" (B.B. II vii I I 7). This directly corresponds to "I must be idle" in the "good" texts (III ii 88), omitted in QI.

(9) After the King has left, discomposed by the entertainment, Hamlet asks Horatio "Sahet ihr....?" (B.B. II viii 50). Compare in the full Shakespearian texts "Didst perceive?" (III ii 287), not found in QI.

(10) On the appearance of the Ghost in the Closetscene Hamlet addresses him as "werther Schatten meines Vaters" and proceeds to ask "was ist dein Begehren?" (III vi I-2). At the corresponding point in the "good" texts we have "What would your gracious figure?" (III iv I04). There is nothing similar in QI. It should also be noticed that in B.B. I v I 5 Hamlet asks the Ghost "Was begehrest du?" This is probably an anticipation of the question in the Closet-scene.

(I I) In B.B. III vi 4 (the Closet-scene) the Queen asks Hamlet "mit wem redet Ihr?" This is closely parallel to her question in the authentic texts- "To whom do you speak this?"'(III iv I 3I)-omitted in QI.

(12) In B.B. III ix 22-3 the mad Ophelia exclaims "Siehe da, mein Kütschchen, mein Kütschchen!" This 
exactly parallels $\mathrm{Q}_{2}$ and $\mathrm{F}_{\mathrm{I}}$, where she says "Come, my coach!" (IV v 70). All mention of her coach is wanting in QI. This is one of Creizenach's clearest instances of agreement between B.B. and $\mathrm{Q}_{2}$ against $\mathrm{Q}_{1}$, and even Tanger was compelled to admit its cogency and regard it as an infiltration into the German version from the final Shakespearian play.

(13) In B.B. III x 6-7 the King says "Gehet hin, und lasset ihn (i.e. the dead Corambus) wegtragen". Compare IV i 36-7 in the full Shakespearian texts, where the King says "Go... bring the body/Into the chapel". Both versions definitely direct the removal of the body. In QI we find only "inquire the body out" (xi I 22).

(14) In B.B. III x I Iff., the King explains to his nephew that the murder of Corambus may result in a movement of the nobles against Hamlet himself; for this reason, as well as for considerations of health (B.B. III x $25 \mathrm{ff}$.), he is to go to England. In the "good" Shakespearian texts (IV iii 39) Claudius says that he has decided that Hamlet must go to England "for thine especial safety", words which must carry some such implication as that of the passage in B.B. In QI, however, we hear nothing of this excuse of possible danger to Hamlet: the King professes concern only about his health (xi I 55), as in earlier passages in both QI and the "good" texts (QI xi I 29, full text In i r 74 ff.).

(15) In B.B. Iv iv 6-7 the King says to Leonhardus "wir sind unschuldig an deines Vaters Tod". This is an exact translation of IV V I49 in the authentic texts: "... I am guiltless of your (i.e. Laertes's) father's death . . .". There is no such verbal parallel in QI.

(I6) In B.B. Iv v $36 \mathrm{ff}$. the King tells Leonhardus that he cannot proceed openly against Hamlet, and gives two excuses for this: (i) his mother supports him, (ii) the King's own subjects love him. In the accredited Shakespearian texts (IV vii I I ff.) Claudius likewise gives two 
excuses: (i) the Queen loves Hamlet inordinately, and he, the King, cannot bring himself to hurt her, (ii) the "general gender" love Hamlet. In the two versions the first pair of excuses, though not identical, correspond: the second pair are identical. ${ }^{I}$ But the whole passage is wanting in $Q_{1}$.

( 17 ) Although in B.B. and $Q_{2}$ the versions of Hamlet's voyage are different, the two texts agree against $\mathrm{Q}_{\mathrm{I}}$ in that Hamlet tells his story to Horatio (see $\mathrm{v}$ ii in both). In QI the story is told by Horatio to the Queen (scene xiv), and we find no corresponding scene between Hamlet and Horatio.

(I 8) In B.B. v vi $18-20$ Hamlet excuses himself to Leonhardus for being out of practice in fencing: Leonhardus replies "Sie scherzen nur". Similarly in the full Shakespearian texts, v ii 253-5, Hamlet depreciates his own ability, and Laertes replies "You mock me, sir". Neither Hamlet's disavowal of skill nor Laertes's reply is found in QI.

(I9) After they have been fencing for a time, Hamlet hits Leonhardus and exclaims "Nun das war eins" (B.B. v vi 23). This parallels his exclamation "One!" in the "good" texts (v ii 278) which is wanting in QI.

(20) On the point of death Leonhardus says to Hamlet "ich bin von dem König zu diesem Unglück verführt worden" (B.B. v vi 40). At the corresponding point in Q2 and FI Laertes tells Hamlet that "the king's to blame" (v ii 3I8). In QI Laertes does not give Hamlet any such information: Hamlet simply divines it.

(2I) Immediately after the Queen's death, Hamlet, about to kill the King, cries "Und Du, Tyranne, sollst

I If the Queen gave Hamlet positive support against the King in the $U r$-Hamlet we may say that while basing this whole passage on $\mathrm{Q}_{2}$ the compilers of the Brudermord text-basis were influenced in their phrasing of part of it by a reminscence of this motif in the old play. 
sie (i.e. the Queen) in dem Tode begleiten" (B.B. v vi 55 ). Similarly in the authentic Shakespearian texts Hamlet despatches Claudius with the exclamation "Follow my mother" (v ii 325), not found in QI.

(22) At the end of B.B. Hamlet directs Horatio to take the crown to Fortinbras. Similarly, at the end of the full Shakespearian play, he prophesies that the election will alight on Fortinbras and says "he has my dying voice" (v ii 354 ). At the end of the QI version, however, Hamlet does not mention the succession.

These are perhaps the most striking instances of agreement between the Brudermord and the full Shakespearian play against the Ist Quarto. But there are other instances, which I shall also give:

(23) In B.B. I i 8 the 2nd Sentinel says "es ist ja nun so kalt nicht": in the "good" Shakespearian texts, I i 8, Francisco says " tis bitter cold". Thus the cold is mentioned in both, at corresponding points, though in contrary senses. But it is not mentioned at all in the corresponding passage in Qr.

(24) In B.B. r i 29 the 2nd Sentinel says to the Ist "Gehe du nur hin"; in the "good" texts, r i 7, Barnardo says "Get thee to bed, Francisco". The texts agree in having the relieving sentry give a direction dismissing the other. There is nothing to correspond in QI.

(25) In B.B. r iv 43-5 Hamlet says to Horatio "Ach! Horatio, ich weiss nicht, warum nach meines Herrn Vaters Tod ich allzeit solche Herzensangst gehabt". This is distinctly similar to II ii 299-300 in the "good" texts, where Hamlet says to Rosencrantz and Guildenstern "I have of late, but wherefore I know not, lost all my mirth". The phrases "ich weiss nicht warum..." and "but wherefore I know not" make it clear that this is a genuine parallel. The passage is not reproduced in QI. I have mentioned the probability that the text underlying B.B. is itself a reported text: where B.B. parallels a Shake- 
spearian phrase which does not occur at the directly corresponding point in the play, we may suppose that the reporter has recollected the phrase out of context, as often happens in QI.

(26) In B.B. I v Io and 20 Hamlet says to the Ghost "Rede". In the corresponding scene in the full Shakespearian texts we have the imperative "Speak" also (I V I), a word absent from the QI version of the encounter.

(27) Just before the meeting between Hamlet and Ophelia (B.B. Ir iii 24) the King says to the Queen "Liebste Gemahlin, Sie lasse sich belieben, in Ihr Gemach zu gehn". Similarly, in the "good" texts (III i 28) he says "Sweet Gertrude, leave us too". In QI, on the other hand, the corresponding speech is given to Corambis"Madame, will it please your grace/To leaue vs here?" (vi I I 2-I 3).

(28) In B.B. II ix 30 Hamlet, summoning up his resolution after the revelation of the King's guilt in the play-scene, makes this declaration to Horatio: "von dieser Stund an will ich darnach treten, wo ich den König allein finde, ihm das Leben zu nehmen". There is an interesting parallel here to words used by Hamlet at the end of his last soliloquy in $Q_{2}$ : "O, from this time forth,/My thoughts be bloody, or be nothing worth" (Iv iv 65-6). Not only is there a verbal parallel, but the import of the two passages is the same though they occur at different points in the play. ${ }^{\mathrm{I}}$ The soliloquy, found in $\mathrm{Q}_{2}$, is omitted not only by QI but also by FI. Note however that QI also contains a trace of this speech: compare $Q_{1}$ xii 3 and $Q_{2}$ rv iv I4. Presumably, then, the whole of IV iv (as found in Q2) was at one time spoken on the stage, even though most of it is absent from $F_{I}$ which represents a transcription of a prompt-copy.

(29) In B.B. III v I9 Corambus, having been stabbed by Hamlet, exclaims "Ich sterbe". Similarly in the I See no. 25 above. 
"good" texts he cries "I am slain" (IIr iv 24), a detail omitted by $Q$ r.

(30) In B.B. III x I 7 ff. Hamlet expresses regret for his murder of Corambus. In the genuine Shakespearian texts we learn from the Queen that Hamlet "weeps for what is done" (IV i 27). QI has nothing to correspond.

(3I) The "Becher" of B.B. IV v 55 is the "chalice" mentioned in the corresponding speech in the "good" texts, IV vii I59. In the corresponding passage in QI (xv 33-6) there is no mention of the vessel.

(32) In B.B. v vi 60-I Hamlet admits that Leonhardus is innocent ("unschuldig"): in the accredited Shakespearian texts ( $v$ ii 329) Laertes himself declares his innocence of Hamlet's death. In QI the question of his innocence is not touched upon at the corresponding point in the play.

(33) In his last speech in B.B. Horatio lists the troubles that have come upon Denmark-"innerliche Unruhe, Regier- Streit- und Mordsucht". In the full Shakespearian versions, v ii 378-8I, Horatio summarizes the subject of his forthcoming oration over the dead bodies: "so shall you hear," he says, "Of carnal, bloody and unnatural acts,/Of accidental judgements, casual slaughters,/ Of deaths put on by cunning and forced cause,...". Admittedly the components of each list are different: but they occupy corresponding positions in the play, and there is no such catalogue in $\mathrm{Q}_{\mathrm{I}}$.

(34) In B.B. II iv $I-2$ Ophelia says to Hamlet "Eure Durchlaucht, nehmen doch das Kleinod wieder...". Similarly, at IIr i 95 in the authentic Shakespearian texts she says "I pray you now receive them (i.e. the 're membrances')". There is no direct parallel in the corre sponding passage in QI (vi I 40-2).

(35) In his last speech in B.B. Iv i Hamlet, having escaped from his would-be murderers, expresses his gratitude for heaven's protection. He likewise speaks of this 
in the "good" texts during the narration of his adventures to Horatio ( $\mathrm{v}$ ii $\mathrm{ro}, 48$ ). There is nothing to correspond in $Q_{I}$.

(36) In B.B. Iv v 30 Leonhardus refers to Hamlet as a "geübter Fechtmeister". In the "good" texts (v ii 209) Hamlet tells Horatio that since Laertes went to France he (Hamlet) has been "in continual practice" at fencing. QI has nothing to correspond.

Having noted the main points in which the Brudermord coincides with $Q_{2}$ and $F_{1}$ against $Q_{1}$, let us turn to the points in which it coincides with $Q_{1}$ against $Q_{2}$ and FI :

(I) In B.B. I vii 16 the King says to Hamlet "bleibt bey uns am Hofe". This parallels QI ii 3 I - "let mee intreat you stay in Court". There is no parallel in the authentic Shakespearian texts (cf. I ii I I 5-I 7).

(2) At II vii $92-4$ in B.B. Hamlet says "Horatio, gieb wohl acht auf den König: wo er sich entfärbt oder alterirt, so hat er gewiss die That verrichtet". This is much closer to the corresponding passage in $Q_{1}$ than to that in $Q_{2}$ and FI. The words "wo er sich entfärbt oder alterirt" parallel with remarkable closeness QI ix 62- "if he doe not bleach, and change at that" (cf. also the word "alteration" in line 66). The corresponding passage in $Q_{2}$ and $F_{I}$ is quite different- "if his occulted guilt/Do not itself unkennel in one speech..." (III ii 78-9): note, however, that at In ii 60I these texts have "if a' do blench". The "good" texts contain nothing corresponding to the word "alterirt". With the words "gieb wohl acht auf den König" in the passage quoted from B.B. cf. QI ix 60"Marke thou the King" and $Q_{2}$ and F I mi ii $78,82-$ "Observe my uncle...give him heedful note".

(3) In the first speech in B.B. II viii the King begs the Queen to be merry and says that they are going to have a play and a ballet: the Queen replies "Ich will solche Lust gar gerne sehn". Although there are circumstantial 
differences, this reminds one of $Q_{I}$ viii $2 \mathrm{I}-2$, where the King says "Gertred you'l see this play", and she answers "My lord I will...". There is nothing to correspond in the "good" texts.

(4) In B.B. II viii I4 Hamlet addresses the King as "Herr Vater": similarly in QI (ix 72) he calls him "father". Nowhere in the genuine texts does Hamlet employ this mode of address to Claudius.

(5) In B.B. III i the King says "Ich fürchte, dass meine Missethat so gross ist, dass sie mir nicht wird können vergeben werden". This closely resembles QI x 7, where the King says "O these are sinnes that are vnpardonable". There is no such explicit statement in the corresponding speech in the authentic Shakespearian texts.

(6) Standing over the praying King Hamlet says in B.B. IIr ii 8-9 "(er) hat ihn (i.e. the elder Hamlet) vielleicht in seinen Sünden schlafend nach der Hölle geschickt". This is much closer to the corresponding passage in QI than to that in the other texts: cf. QI x I6-"he tooke my father sleeping, his sins brim full", "good" texts III iii 80-I - "A' took my father grossly, full of bread,/ With all his crimes broad blown...". But cf. I v 74-6 in $Q_{2}$ and $F_{1}$.

(7) In B.B. III v I 5 (the Closet-scene) Hamlet asks if the doors are locked. This is peculiar to the German text, but in QI xi 7 he says "first weele make all safe", which must surely refer to some such action as locking the door. There is nothing to correspond in the other texts.

(8) On the appearance of the Ghost during Hamlet's interview with his mother, the hero cries out in B.B. "forderst du Rache?" (III vi 2). In the corresponding speech in QI (xi 62-70) the word "revenge" occurs twice, while in the version of $\mathrm{Q}_{2}$ and FI (III iv IO3-4, 106-9) the word does not appear.

(9) In B.B. III X 5 the King uses the phrase "Es ist leid uns...", and it is a favourite formula in the German 
text. Very similar phrases appear twice in $Q_{I}$ (vi 3, xiii 58) but not in the "good" texts.

(Io) Announcing to Hamlet his plan for sending him to England the King says "Wir aber aus väterlicher Vorsorge haben ein Mittel erfunden..." (B.B. III x I4). In the corresponding speech in QI (xi 1 55) he says "we in care of you..." where the word "care" is in all probability a borrowing from Henry $V$, Ir ii 57 . There is nothing corresponding to "Vorsorge" or "care" in the corresponding passage in the full Shakespearian texts (Iv iii 39-45).

(I I) B.B. III $\times 25-7$ presents an interesting parallel to a passage peculiar to QI among English texts. Speaking to Hamlet, and enlarging on his decision to send him to England, the King says "als könnt Ihr Euch eine Zeit, weil eine gesundere Luft allda, in etwas refrigiren, und zu Eurer Genesung besser als hier gelangen". Compare with this QI xi r 29-30, where the King says that he has sent letters to the King of England "For Hamlets welfare and his happinesse" and proceeds "Happly the aire and climate of the Country/May please him better than his natiue home". The corresponding passage in the "good" texts is III i I 74-8, not nearly so close to the German: "Haply the seas, and countries different, $/$ ith variable objects, shall expel/This something-settled matter in his heart...".

(12) In B.B. III x 45-6 the King tells Hamlet's two attendants that "er nimmer wieder aus England kommen soll". Compare Q1 xi I68, where the King says in soliloquy "To England is he gone, ne're to returne". There is no verbal parallel in the other texts.

(13) B.B. and QI agree in making the King suggest the poisoning of the rapier that is to kill Hamlet: in the "good" texts this suggestion is Laertes's (see B. B. IV v 23-7, QI xv 2 I-4, full Shakespearian text IV vii I 39-47).

(14) In B.B. Iv vi 3 the King calls the Queen "liebste 
Seele". Similarly in Qr xiii 9 he calls her "deere heart". There is no parallel in the other texts.

(I 5) In B.B. Iv vi the Queen tells the King that Ophelia has gone mad before Ophelia herself appears. This is also the case in QI (see xiii 6-8). In the authentic Shakespearian texts, on the other hand, the King enters while the mad Ophelia is on the stage with the Queen (IV V 35 S.D.).

(I6) In B.B. IV vii, after the mad Ophelia has gone out, Leonhardus states his griefs-"Mein Vater ist todt, und meine Schwester ist ihres Verstandes beraubt". Similarly in QI, at exactly the same point, Laertes cries "...my father murdered,/My sister thus distracted" (xiii I I 4-I 5). The QI passage is based on IV vii $25-6$ in the authorized texts, but B.B. and QI agree against these as regards the position of the passage.

(I 7) In B.B. v iii $26 \mathrm{ff}$. Hamlet says "Phantasmo, gehe wieder hin zum Könige, und sage ihm, dass ich ihm bald aufwarten werde". This is a close parallel to QI xviii 33"Goe tell his maiestie, I wil attend him", spoken to the character corresponding to Osric (the "braggart gentleman"). There is nothing so close to B.B. in the received text of Shakespeare's full play (see vii I 74-5, 179-80, and, in Q2 only, 196-7).

(I8) On the point of death, Hamlet says in B.B. "Ich werde ganz matt, meine Glieder werden schwach, und meine Beine wollen nicht mehr stehn; meine Sprache vergeht mir,..." (v vi 8I-3). In the same way in QI he speaks of his physical symptoms, one of which is the same as in B.B.- "O my heart sinckes Horatio,/Mine eyes haue lost their sight, my tongue his vse" (xviii I06-7). No corresponding list is found in $\mathrm{Q}_{2}$ or $\mathrm{F}_{\mathrm{I}}$.

Three other agreements have been mentioned in earlier chapters:

(ig) In B.B. v ii 13 Hamlet tells Horatio that one day, during his voyage, "wir... contrairen Wind hatten". 
Similarly in QI xiv 5, Horatio tells the Queen that Hamlet's ship was "crossed by the contention of the windes". There is nothing of this in the genuine Shakespearian texts.

(20) Throughout B.B. the King's counsellor is called Corambus, the same name as in QI, where however it is spelt Corambis, probably through error.

(2I) B.B. and QI agree against the other texts in the position of the "nunnery" scene.

These are the main respects in which the Brudermord agrees with the $Q_{I}$ text against those of $Q_{2}$ and $F_{1}{ }^{I}{ }^{I}$ e must now attempt to account for the co-existence of these two sets of parallels.

\section{THE CONSTRUCTION OF THE GERMAN TEXT}

I am convinced that one episode in the Brudermord is derived from the Ur-Hamlet, namely, the hero's adventure with the two "banditen" on the island near Dover. I have already given my reason for this opinion, ${ }^{2}$ and also my reason for believing that one or two other passages in the German play are probably based upon corresponding passages in the pre-Shakespearian version. 3 And some critics have placed yet other passages in the same category: with these we shall deal later.

It by no means follows, however, that the Brudermord as a whole is based upon the Ur-Hamlet. At one or two points in the QI text, which is essentially based upon the Q2 version (or upon a version very close to it), we have detected traces of an earlier version, probably the preShakespearian play; and we have suggested that at these points the reporter has contaminated what is basically a reconstruction of the final Shakespearian version by borrowing from that earlier version-that is to say, we have

I There are others, which may however be simply coincidence.

2 See p. r 91 .

3 See pp. $200 \mathrm{ff}$. 
suggested that at certain points the QI text is a conglomeration of material drawn from two separate stages in the Hamlet text-history. In view of the fact that the text of the Brudermord may be analogous, we cannot jump to the conclusion that it is based directly upon the UrHamlet even although it contains certain traces of the latter.

One of the most striking features of the German text is its frequent closeness to the full Shakespearian version of $\mathrm{Q}^{2}$. It is a curt and perfunctory prose piece, with little or no poetic content. ${ }^{\mathrm{I}}$ Furthermore, as has already been said, the text we have is separated from its own original state by about a century of German stage tradition, and was initially in all likelihood concocted from memory. Yet despite all this, and not leaving out of account decided differences, such as the story of Hamlet's voyage, the treatment of Ophelia's madness, the content of Hamlet's advice to the players, etc., it is remarkably close to the $\mathrm{Q}_{2}$ play, not only generally in outline but also in numerous phraseological and other details. The list of agreements between the Brudermord and $Q_{2}$ against $Q_{1}$ was drawn up to show that the German text was not based directly upon that of QI as Tanger thought. It also provides in certain verbal parallels specimens of the closeness of the relationship at certain points between the Brudermord and the $\mathrm{Q}_{2}$ text. But if we compiled a list to show all the coincidences, verbal and otherwise, between the two texts irrespective of whether QI agreed or not, we should find it an extremely lengthy catalogue. If in the main the Brudermord represents the old Hamlet, then the latter resembled Shakespeare's full play very much more than I should be prepared to suppose was the case.

I want to maintain as the most reasonable working hypothesis the supposition that, when the play to be taken to the continent was compiled, the $Q_{2}$ text-or a text I Except in the Prologue. 
close to it-was already in existence, ${ }^{\mathrm{I}}$ and that the compiler or compilers relied mainly upon their recollection of that, from which however they deviated at certain points, incorporating in their version material taken in some cases from the $Q_{I}$ text and in others from the Ur-Hamlet. These deviations from the full Shakespearian play may have been either involuntary - the result of memorial confusion-or, in some cases, intentional.

\section{THE BRUDERMORD AND Q $\mathrm{r}$}

In discussing the QI account of Hamlet's voyage we noted certain details which must have been taken from a version closely resembling that of the Brudermord, and we were led to suppose that this must have been the version of the Ur-Hamlet. But it was not simply the coincidence between QI and the Brudermord which led to this conclusion; it was the fact that the QI account of the story was quite incoherent, mixing elements from the Brudermord and Q2, whereas that of the Brudermord was on the whole coherent. This being so it was reasonable to suggest that the latter was derived from a source earlier than Q $\mathrm{r}$, and this can only have been the old play since it was neither Saxo nor Belleforest. Mere agreement between the Brudermord and QI is no criterion of derivation from the $U r$ Hamlet. Indeed, certain parallels between these two texts point to a quite different conclusion. For in quite a number of the instances listed above, the Brudermord closely parallels passages in QI which almost certainly owe their existence or form to the reporter responsible for the latter, and which in all probability never stood as they do in $\mathrm{Q}_{\mathrm{I}}$ in any authentic Hamlet text, pre-Shakespearian or otherwise.

I The $\mathrm{Q}_{2}$ edition cannot yet have been published, however, since, had it been so, we should expect the travelling players to have used a copy of it instead of going to the trouble of constructing a version for themselves. 
Take the first item in the list of agreements between the Brudermord and $\mathrm{Q}_{1}$ against $\mathrm{Q}_{2}$ and $\mathrm{F}_{\mathrm{I}}$. The King's words to Hamlet, "bleibt bey uns am Hofe", closely parallel those in QI, "let mee intreat you stay in Court". The corresponding passage in $\mathrm{Q}_{2}$ and $\mathrm{F}_{\mathrm{I}}$ is different:

And we beseech you, bend you to remain Here in the cheer and comfort of our eye,...

(I ii I I 5-I6)

But the QI reporter has simply confused this passage with a later speech delivered by the King to Rosencrantz and Guildenstern in the authorized texts:

I entreat you both,

That you vouchsafe your rest here in our court

Some little time,...

(II ii IO-I 4)

The confusion is proved not only by the words "in Court" in the line quoted from QI, but also by the word "intreat" in that line (not paralleled in the Brudermord).

Passing to the second item in the list, we note the close parallelism between "wo er sich entfärbt oder alterirt" and the line in QI which runs "if he doe not bleach, and change at that", a line not found at the corresponding point in the true Shakespearian texts. But in writing the first part of this line the QI reporter was simply recollecting out of place Hamlet's words in his soliloquy at the end of Act Ir in $Q_{2}$ and $F_{I}$ - "if a" do blench/I know my course" (II ii $60 \mathrm{I}-2$ ).

A similar explanation is forthcoming for no. 6 in our catalogue. In the Brudermord Hamlet says that the King "hat ihn (i.e. the elder Hamlet) vielleicht in seinen Sünden schlafend nach der Hölle geschickt", which is closely parallel to the corresponding passage in $\mathrm{Q}_{1}$ - "he tooke my father sleeping, his sins brim full" - as opposed to the $\mathrm{Q}_{2}$ and $\mathrm{F}_{\mathrm{I}}$ version, " $\mathrm{A}$ ' took my father grossly, full of 
bread". The QI reporter has confused this with the Ghost's own narrative away back in Act I of the full play:

Thus was I sleeping by a brother's hand,

Of life, of crown, of queen at once dispatched,

Cut off even in the blossoms of my sin,... (I v 74-6)

Another case in point occurs in no. 16 of the list we are considering. The Brudermord parallels a passage found in QI at exactly the same point in the play, but based upon a passage in a different part of the $\mathrm{Q}_{2}$ text. The phrasing of the QI passage can be confidently attributed to the reporter: it is therefore reasonable to attribute its position to him also. The passage runs thus in $\mathrm{Q}_{\mathrm{r}}$ :

Lear. Griefe vpon griefe, my father murdered, My sister thus distracted:...

(xiii I I 4-I 5)

This is founded on the following passage from the "good" texts:

And so have I a noble father lost,

A sister driven into desperate terms,... (Iv vii 25-6)

The QI reporter has confused this with two other passages in the full Shakespearian text-first, II ii 587 where Hamlet talks of himself as "the son of a dear father murdered"; and second, IV v 2 where it is said of Ophelia that "she is importunate, indeed distract".

Again, consider no. Io in our list. In the Brudermord the King declares that he has arranged for Hamlet's voyage out of paternal solicitude-"aus väterlicher Vorsorge". This phrase parallels words used at the corresponding point in $\mathrm{Q}_{1}$ :

Well sonne Hamlet, we in care of you: but specially in tender preseruation of your health,...

(xi $155-6$ )

But as has already been pointed out the word "care" here was appropriated by the reporter from Henry $V$, Ir ii 57 . 
That this is indeed the source of the word in $\mathrm{QI}$ is proved by the fact that the reporter has also lifted (with modification) the next line in Henry $V$ :

\section{.... in their dear care \\ And tender preservation of our person.}

Thus the Brudermord parallels a word which the QI reporter had filched from another play. ${ }^{\mathrm{I}}$

Also of interest here are nos. 3, 5, 9 and II in the list of parallels between the Brudermord and $\mathrm{Q}_{1}$ against $\mathrm{Q}_{2}$. In these cases the German text agrees with lines in passages which I have shown in Chapter IV to be without doubt the original work of the reporter-versifier who was implicated, whether alone or with others, in the transmission of the "bad" text. There is not the slightest reason to suppose that in the relevant four passages in $\mathrm{Q}_{\mathrm{I}}$ this reporter-versifier was indebted to the old play. It should also be mentioned that in nos. 8, 1 2, I 4, I 5, I 7 and I 8 in the same list the Brudermord parallels words from passages in QI which agree in style with those specimens of the reporter-versifier's work which we examined, and which may therefore be assigned to his invention.

We are now faced with this position: (I) since the Brudermord parallels $\mathrm{Q}_{2}$ against $\mathrm{Q}_{1}$ in over thirty particulars ${ }^{2}$ it cannot have been directly based upon the text of QI ; but (2) in a certain number of passages the Brudermord is indebted to passages in QI which owe their existence, form, or position in that text to the blundering of the reporter-that is to say, of the parallels between Q $I$ and the Brudermord these at any rate are not the result of

${ }^{1}$ Cf. also no. 5 in the list of parallels between the Brudermord and $Q_{1}$ against $Q_{2}$; here the Brudermord parallels a line in $Q_{1}$ which may have been derived by the reporter-versifier from 3 Henry VI, as pointed out on p. II 2 .

${ }^{2}$ A more impressive number than that of the instances in which it parallels $Q_{1}$ against $Q_{2}$.

D B $Q$ 
dependence upon a common original, whether the old Hamlet, a Shakespearian first draft, or, as Creizenach thought, a stage-version of the $\mathrm{Q}_{2}$ text. ${ }^{\mathrm{I}}$ The question now arises, were these borrowings from the QI text made from memory or by actual consultation of that text in manuscript or in print? Of the alternatives I regard the first as certainly the more probable. At most, the provable indebtedness of the Brudermord to QI is comparatively slight, mainly restricted to isolated words and phrases scattered throughout the play; and these look much more like sporadic reminiscences than anything else. I would suggest the following hypothesis as co-ordinating the two facts of the indebtedness of the Brudermord to the $Q_{2}$ text on the one hand and to the text of QI itself on the other (remembering that the indebtedness in the first case is much greater than in the second). It is by no means rash to suppose that the QI text was botched up from memory in order to furnish a group of actors in the provinces with prompt-copy - that is, to suppose that this text is essentially of the same class as Orlando Furioso. We know that actors were sometimes driven to try their fortunes abroad by lack of success in England. ${ }^{2}$ It is likely that such actors would be forced to employ a similar method to procure acting copy, and that the Brudermord is basically a memorial reconstruction made for this purpose. A journey overseas

${ }^{1}$ As for the remainder of the agreements between the Brudermord and $Q_{1}$ against $Q_{2}$ : we have already said that their agreement in the position of the "nunnery" scene may be due either to direct borrowing in the German version or to dependence on a common source (possibly a stage-version of the full text). Their agreement as to the adverse winds which Hamlet's ship encountered is certainly due to dependence on a common source, viz. the Ur-Hamlet. The other items in the relevant list which I have not specifically claimed as direct borrowings in the Brudermord from the QI text may in fact be such borrowings or on the other hand derived from a common source. What I wish to emphasize here is that the Brudermord contains some passages which were certainly taken from the Qr version itself.

${ }^{2}$ See Cohn, Shakespeare in Germany, introduction. 
may well have been in the nature of a last resort, and we may regard it as not improbable that players who undertook such a journey would already, at least in some cases, have failed in the English provinces. Suppose that a group of actors, about to travel abroad, set themselves to trump up a memorial reconstruction or summary of what they could remember of the full Shakespearian text, one or more of their personnel having played minor parts in it. Suppose also that one or more of this group had taken part in a version which had been illicitly compiled for performance by a company in the English provinces (the QI text). This would account admirably for the fact that reminiscences of this QI text are found in the Brudermord, which is not however directly based on it. The group of actors which went abroad is not likely to have been identical with that which toured the English provinces with the QI version: for in that case surely they would simply have taken their manuscript of that version to the continent with them. My hypothesis is that one or two members of the English provincial group in question broke away and joined other destitute players in a foreign tour. The manuscript of the QI text presumably remained in the hands of the rest of the provincial group, who were ultimately forced by poverty to sell it to the publishers Ling and Trundell. What we may call the continental group proceeded to a communal attempt at reconstructing, or summarizing, the full Shakespearian version, or one close to it (e.g. a stage-version): and during the process these ex-members of the provincial group were responsible for introducing some traces of the $Q_{I}$ text which they happened to remember. Furthermore, during the said reconstruction, some traces of the pre-Shakespearian Hamlet appear also to have been introduced. 


\section{THE BRUDERMORD AND THE UR-HAMLET}

I have claimed that the episode of Hamlet and the two "banditen" in the Brudermord is based upon the preShakespearian play. I have also claimed as traces of this early play passages in which the Brudermord, and no other dramatic Hamlet-text, closely parallels Belleforest: in this category I would confidently place (i) the passage at the end of $\mathrm{I}$ vi in the German text where Hamlet declares that he will exact from the King a vengeance which will be renowned among posterity for ever, and (ii) the passage in the German version of the Closet-scene where the Queen holds herself responsible for her son's apparent insanity (III vi $15 \mathrm{ff}$.). As another possible case in point I would mention Hamlet's gibe at his mother's "crocodile tears" (Brudermord, III v 6). I have already quoted these passages, and the corresponding passages in Belleforest. ${ }^{\mathrm{I}}$ We must either believe that these parallels are coincidences, which would, at least in the first and second cases, be most remarkable; or that the compilers of the text taken to Germany consulted Belleforest, a suggestion which I have already discounted as in my opinion extremely unlikely; ${ }^{2}$ or that these compilers were here indebted to their recollection of passages in the old Hamlet which were based on these passages in the prose source. The last seems by far the likeliest hypothesis. The introduction of these passages into the text-basis of the Brudermord was probably involuntary, through memorial confusion of two different stages of the play's history. But the episode of the "banditen" was probably reintroduced as being more exciting in action than the recital in the $\mathrm{Q}_{2}$ text of events not presentable on the stage - that is, it was reverted to as a measure of stageadaptation.

${ }^{I}$ See pp. $200 \mathrm{ff}$.

${ }^{2}$ See p. 203. 
The above are the only portions of the German text for which we have in my opinion anything approaching positive indications of derivation from the pre-Shakespearian Hamlet. There may be other traces, though none can be proved to be so. But even if there are, our hypothesis remains unaltered; we have simply a larger measure of indebtedness to the old play on the part of the compilers of the Brudermord text-basis instead of a smaller.

The name Corambus may belong to the old play, but even if it does it may simply be retained in the German version because it had been used in that given in Q1. It is even possible that the old name was reverted to in a stageversion subsequent to the $\mathrm{Q}_{2}$ text-a stage-version in which the position of the "nunnery" scene had been altered: and it is possible that in these respects QI and the Brudermord are indebted to this version. Did the King suggest the poisoning of the rapier in the old Hamlet, as in QI and the Brudermord, or is this simply a blunder (or deliberate alteration) by the QI reporter, retained by the compilers of the text carried to Germany? Did Hamlet address the King as "father" in the old play, as in QI and the Brudermord, or is this also the invention of the QI reporter, repeated in the German text? There is no way of telling.

Among the passages peculiar to the Brudermord for which derivation from the Ur-Hamlet has been plausibly suggested, though not proved, is that in which, the King having told Hamlet that he is to go to England, the latter replies: "Ja, ja, König, schickt mich nur nach Portugall, auf dass ich nimmer wieder komme, das ist das beste" (III x 30-I). Latham ${ }^{I}$ suggested that this is an allusion to the disastrous expedition to Portugal, undertaken in 1589 by Drake and Norris, and joined by Essex, for the purpose

I Two Dissertations on the Hamlet of Saxo Grammaticus and of Shakespeare (1872), pp. 100-4. 
of placing on the Portuguese throne the illegitimate Don Antonio who had taken refuge in England. The proportion of casualties was enormous. If the allusion is to this event, and if as would then seem most likely the passage is derived from the Ur-Hamlet, one might fairly assume that the latter was written in 1589 and that in his epistle to the Menaphon Nashe was referring to a new play. But Appleton Morgan ${ }^{\mathrm{I}}$ mentions another possibility. The Ur-Hamlet may have been written before 1589 and Hamlet's allusion to Portugal may have been a "gag" inserted by actors in 1589 . The English actors in Germany may then have remembered and used it, though it would have little point after the turn of the century, over ten years after the disaster, and none at all outside England. Creizenach attempts to refer the allusion to other later historical events in which German audiences would take an interest: Sir Edmund Chambers points out that "Germany had been interested in Portugal, for example, during the war of Portuguese independence in I66I and that of the Spanish succession in 1704 " 2 -the allusion may be an insertion made during the stage-history of the play in Germany before 1710 . Though we cannot tell to what event the allusion refers, it seems obvious that it is indeed an historical allusion. Attempts to deprive it of any allusive intent do not carry conviction. Creizenach suggested alternatively that Hamlet is merely uttering meaningless ravings in accordance with his assumption of the disguise of madness. Furnivall pointed out that "a good many of us have made non-contemporary allusions to "Go to Jericho, Coventry, or Bath': such phrases live long after the days in which they rose." 3 Admittedly, but there is no other evidence for the existence of the phrase "to go

I Shakespeariana (Shakespeare Society of New York), vol. viII (189r), pp. 5-6.
2 William Shakespeare, vol. I, p. 423 .
3 Introduction to Griggs's facsimile of $Q$,, $\mathrm{p} . \mathrm{x}$. 
to Portugal". I Furnivall is right, however, in declaring that if this Portugal allusion is the only strong point in the case for the derivation of the Brudermord from the $U_{r}$ Hamlet then "we need not trouble ourselves with that case much further". ${ }^{2}$ But he states that it is the only strong point, and here I disagree: the strongest point is the episode of Hamlet and the "banditen".

What of the Prologue to the Brudermord? It is thoroughly Senecan in style, and we know from Nashe that this was true of the old Hamlet as a whole. This is not sufficient, however, to warrant the assumption that in the Brudermord we have the Prologue of the old play. There is no possibility of a conclusion on the matter. Even the fact that the Prologue does not in all respects fit the play is susceptible of more than one explanation. The allegorical figure of Night instructs her minions to spoil the marriage of the King and Queen by creating jealousy between them: she also tells them to kindle a fire of revenge which will scatter its sparks throughout the entire kingdom. No motif of jealousy figures in the Brudermord, nor is the kingdom as a whole involved in the exaction of

I Another attempt to deprive the passage of any particular historical reference is made by Dr A. S. Cairncross. In The Problem of Hamlet: a Solution, p. 121, he writes: "In The First Part of Ieronimo, Don Horatio is informed 'He meanes to send you to heauen, when you returne from Portugale' (II iii 42-43). Service in Portugal was so severe and dangerous that there was little chance of his return, and it was for that reason that he was being sent. This is a scene that the pirate would naturally associate with the sending of Hamlet to England, on a similar errand." But this is utterly inaccurate. The words quoted from I Ieronimo are addressed to Andrea, in a letter to him dictated by Ieronimo to Horatio: Andrea was sent to Portugal on a bona fide embassage: the danger to which he was exposed lay not in Portugal but in the fact that Lorenzo had planned to murder him on his return to Spain. There is no analogy whatever to Hamlet's words in the Brudermord, and no reason for suggesting any connection.

${ }^{2}$ Op. cit. p. x. 
vengeance from the $\mathrm{King}$. Is this the Prologue to the Ur-Hamlet, prefixed to a text only fragmentarily derived from that play? Or is it, as Creizenach suggested, the Prologue to some other German play, employed for Hamlet but insufficiently adapted for the purpose? Or is it a Prologue specially written for the German Hamlet by someone who did his work inefficiently inasmuch as he introduced themes not in every case appropriate to the play itself? We cannot say. Sarrazin regarded the Prologue as based on that of the Ur-Hamlet, but believed that the Brudermord itself represented a Shakespearian first draft. ${ }^{\mathrm{I}}$ Professor H. D. Gray suggests that the group of actors which took the play to Germany included one who had taken the part of Night in the Prologue to the old play, that he reconstructed this Prologue, and that it was prefixed to a debased version of Shakespeare's play of I 600-I. ${ }^{2}$ The theory that the Brudermord Prologue is based on that of the pre-Shakespearian play, while the main part of the German play is not directly based on that, is quite possible, and would fit the hypothesis by which I am seeking to explain the Brudermord as a whole. But in this particular there is nothing approaching proof, although the Prologue approximates more nearly than any other part of the German text to the style of Kyd who may have been the author of the old play.

Alleged agreement with Belleforest against $Q_{1}, Q_{2}$, and $\mathrm{F}_{\mathrm{I}}$ has been pointed out at the beginning of II $\mathrm{V}$ in the Brudermord, where Hamlet tells Horatio that since the $\mathrm{King}$ is always surrounded by guards his attempt to exact vengeance may fail. It has been claimed that this circumstance is paralleled in Belleforest, and this is so to a certain extent, though not entirely. In Belleforest it appears that practically the entire court is on the King's side against Amleth, and that there is no one whom he can trust. For

I Anglia, vol. XIII (1890), pp. $122 \mathrm{ff}$.

2 Philological 2uarterly, vol. vII (1928), p. 258. 
this reason he himself says that he must tread warily in his quest for revenge, ${ }^{\mathrm{I}}$. and for the same reason the Queen warns him to act circumspectly. ${ }^{2}$ It is possible, therefore, that in the Ur-Hamlet the hero's delay was caused largely by purely objective hindrances, and that the Brudermord preserves a trace of this. ${ }^{3}$

Nothing is proved by Blakemore Evans's citation of passages and motifs in the Brudermord which closely resemble passages and motifs in extant works of Kyd. ${ }^{4}$ Even granting that the Ur-Hamlet may have been written by $\mathrm{K} y \mathrm{~d}$, there is no reason to suppose that in the Brudermord these are derived from that play (in which case we should have to convict $\mathrm{K} y \mathrm{~d}$ of flagrantly repeating himself in different plays). The case is here the same as with regard to the quotations from $\mathrm{Kyd}$ in the Ist Quarto.5 As in several passages in that text, so also in the Brudermord we find at least one parallel with The Spanish Tragedy so close that we must suppose that the compilers of the former appropriated it from the latter. At the end of II vii in the German text Hamlet instructs Horatio to watch the King's behaviour during the play, and Horatio replies "Ihro Durchlaucht, ich werde meinen Augen eine scarfe Aufsicht anbefehlen". This is clearly a direct adaptation of The Spanish Tragedy, III xiii 39-40, where Hieronimo says to himself "thou must enjoin/Thine eyes to observation". The matter is complicated by the fact that at exactly the same point in QI there is a sort of parallel: Horatio says "My lord, mine eies shall still be on his face" (ix 65). The obvious explanation is that the compilers of

I See Gollancz, Sources of "Hamlet", p. 2 i6.

2 Ibid. pp. 220-2.

3 But the Brudermord has the "Pyrrhus-scene" and the playscene. The first shows Hamlet "lapsed in time" and the second shows him desirous of corroboration of the Ghost's narrative, just as in $Q_{2}$ upon which, in my opinion, the German version is mainly based.

4 See Modern Philology, vol. II (1904-5), pp. $433 \mathrm{ff}$.

5 See Chapter vII, $\$$ I. 
the text taken to Germany remembered the purport of this line in QI, but reproduced it in words borrowed from The Spanish Tragedy. We have certain knowledge that those responsible for the Brudermord were indebted to other plays. For, in planning the play-scene, Hamlet illustrates the effect upon a criminal of a re-enactment of his misdeeds by relating the story of a woman who was thus induced to confess a murder committed nine years before (II vii $96 \mathrm{ff}$.): this is directly borrowed from $A W$ arning for Fair Women (Q I 599, sig. $\mathrm{H}_{2}$ recto).

Unanswerable problems multiply. In the Brudermord we are explicitly informed that Ophelia committed suicide by throwing herself down from a mountain top ( $v$ vi 5 ): in $Q_{1}, Q_{2}$, and $F_{1}$ she is accidentally drowned, yet the Church treats her as a suicide. Does the German version preserve the original manner of her death, incompletely altered by Shakespeare? Or did the compilers of the Brudermord simply make her kill herself because they remembered that there were passages in $\mathrm{Q}_{2}$ which indicated this, and did they evolve the nature of her suicide by a conflation of the passage in The Spanish Tragedy where we hear that the Bashaw

moved with remorse of his misdeeds, Ran to a mountain top and hung himself,

and that in Antonio and Mellida ${ }^{\mathrm{I}}$ where we are told Antonio's fate:

Distraught and raving, from a turret's top

He threw his body in the swollen sea.

It is fully as possible to believe that in this respect the compilers of the Brudermord text-basis altered the $\mathrm{Q}_{2}$ text as to suppose that their account antedates that of $\mathrm{Q}^{2}$. There is nothing to tip the balance either way.

1 Entered in the Stationers' Register on October 24, $160 \mathrm{r}$. 
Finally, let us consider an argument originally put forward by Latham. ${ }^{\mathrm{I}}$ At II ii 395 in the full Shakespearian play Hamlet says "When Roscius was an actor in Rome...". Q1 corrupts the name to "Rossios" (vii 97). But in the Brudermord the reference is to "Marus Russig". Latham suggested that this form is the result of a confusion between the actor Quintus Roscius and another person altogether-Sextus Roscius Amerinus, the subject of Cicero's speech Pro Roscio Amerino, and not of course an actor. "Now this is a blunder," says Latham, "that requires as much scholarship to achieve as to avoid; being one that a learned man might make from inadvertency whereas an unlearned one could not make it at all. It was certainly not made by Shakespeare. This we know from his text, where Roscius stands alone. It could scarcely have been made by the supposed adapters who came after him." Again, Latham suggests that the passage in the Brudermord which corresponds to $\mathrm{v}$ ii $98-105$ in the authentic texts and xviii II-I4 in QI, is nearer to Juvenal ${ }^{2}$ than either. Here, as in the other case, Latham would attribute the requisite classical learning to the author of the pre-Shakespearian Hamlet, two traces of which are, he suggests, preserved here in the Brudermord. But I do not think that the argument is very strong. In the first case it is by no means necessary to suppose that "Marus" is a corruption of "Amerinus". It may well be a simple error for "Marcus", or even "Marius". Some ignoramus may simply have inserted a Latin name he happened to know in order to give Roscius a praenomen, even though it was the wrong one (if Marcus was intended) or an impossible one (if Marius). In the second case it seems to me quite easy to suppose that the relevant passage in the German text was based directly upon that found in $Q_{2}$. It is admittedly closer in one detail to Juvenal: in the Brudermord we have:

I Two Dissertations, pp. 96-9.

2 Satire III, lines roo-3. 
Hamlet. But now there's a great heat.

(Wipes his face.

Phantasmo. O what a horrible heat! (Also wipes away the sweat. and in Juvenal:

...si dixeris "Aestuo", sudat. ${ }^{\mathrm{X}}$

The only respect in which the Brudermord is closer to the Latin is the detail in the second stage-direction, which provides for stage by-play which might well be implied in Shakespeare's own text and which might have been indulged in during performances by Shakespeare's own company. The whole Shakespearian passage may have had a prototype in the old Hamlet, and this may have been based upon the Juvenal passage. But there is no need to suppose that the compilers of the Brudermord text-basis had the old Hamlet in mind.

Summing up the position quite briefly, I should say that in the Brudermord there are some traces of the preShakespearian Hamlet. On the other hand, not a few passages which have been placed in this category by certain critics and which may indeed be proper to it cannot be proved to be so and may be otherwise explained. Indebtedness to the old play is a fact, but the extent of that indebtedness is not determinable.

\section{GERMAN STAGE-ADAPTATION}

It has been pointed out that approximately a century of stage-history intervenes between the creation of the text originally taken to the continent and the emergence of the text which we possess. During this time various changes have been introduced, most notably in one direction. One of the most characteristic features of our text is the low comedy which it contains. At the beginning of the play the uneasiness of the second sentinel is presented in a comic light. Even more striking is the coarse treatment of the

$$
\text { I Line ro3. }
$$


madness of Ophelia, furthered by the introduction of the character Jens. I see no reason to doubt the correctness of the general view that these are alterations effected during the continental stage-history of the play, and they will serve as excellent examples of an element in the extant text which must certainly be reckoned with. It is of course impossible to determine the extent to which our text differs from that originally taken to Germany: Dr Greg points out the possibility that the latter was even superior to the text of $Q_{1}$, and that "the degradation of the extant text may be entirely due to theatrical conditions in Germany".

\section{CONCLUSION: THE HYPOTHESIS}

In the extant Brudermord text, which is basically a memorial reconstruction, material is drawn from four distinct sources:

(I) It is chiefly based upon Shakespeare's play as contained in $\mathrm{Q}_{2}$, or upon a version close to that (e.g. a stageversion).

(2) Elements are introduced, doubtless involuntarily, from the text found in QI, which is probably an illegitimate provincial acting-version.

(3) Elements are introduced from the pre-Shakespearian Hamlet. These may in some cases have been introduced involuntarily; but at least one was probably deliberate.

(4) Alterations and additions have been made during the continental stage-history of the play prior to 1710 . We may of course add that alterations may have been made initially by the original compilers. ${ }^{2}$

I See Foreword, p. xi.

2 I have said that it is impossible to determine the extent of this last category. For example, I would include in it the content of 
Thus the German text is a conglomerate, and does not represent the Hamlet play as it stood at any authentic stage in its development.

Hamlet's advice to the players-in the Brudermord he is concerned with the question of costume. It is probably an alteration of Shakespeare. There is no proof: but neither is there proof of any other explanation. 


\section{THE FIRST QUARTO: CONCLUSIONS}

We have found that in considering the first Quarto text of Hamlet we do not escape some unanswerable problems. Did the old play, or a Shakespearian first draft, contain a dialogue between Horatio and the Queen corresponding to that in QI scene xiv? I have claimed that in this scene the dialogue embodies material taken from the full Shakespearian play incoherently confused with material taken from the old play. Was the staging taken from the old play? In my opinion the Brudermord preserves the UrHamlet version of the episode described in Q1 scene xiv, and in the Brudermord the story is related by Hamlet to Horatio as in $\mathrm{Q}_{2}$ and $\mathrm{F}_{\mathrm{I}}$. But according to my hypothesis this does not necessarily mean that it was related by Hamlet to Horatio in the pre-Shakespearian play: the persons responsible for the text-basis of the Brudermord may have retained the $\mathrm{Q}_{2}$-text staging in this respect, while reverting to the Ur-Hamlet story. The QI staging may preserve a trace of the old play. But on the other hand it is equally possible that this QI staging was the invention of the reporter, or of a stage-adapter of the full Shakespearian play. I can see no evidence on either side; we are left with only a balance of probabilities.

Again, consider the question of abridgment. Is the fact that the $Q_{1}$ text is so much shorter than those of $Q_{2}$ and $F_{I}$ due in any measure to abridgment in the version underlying it, as well as to defective memorial transmission? And if so, in what measure? Mr Crompton Rhodes thinks that the brevity of the QI text was "less deliberate than determined by...f failure of memory" on the part of the reporter: $\mathrm{Mr}$ Alfred Hart attributes it in part to deliberate 
abridgment. ${ }^{\mathrm{I}}$ I can find no evidence either way. There is no omission in the text which could not be the result of simple failure of memory on the reporter's part; on the other hand, nothing would surprise me less than that a fairly drastic stage abridgment of Hamlet was made, legitimately or otherwise, for provincial performance.

These are examples of problems which cannot positively be answered. There is another question, to which the $Q_{I}$ text itself gives no answer, but to which, as we have seen, a solution is suggested by Der Bestrafte Brudermord. Was the memorial reconstruction given in $\mathrm{Q}_{\mathrm{I}}$ undertaken to provide some band of actors with a prompt-copy-a prompt-copy to which they were not entitled? Or was it undertaken at the instigation of the publishers? I have suggested that the first of these answers is the correct one. The Brudermord is not directly based upon the QI text, but it contains echoes of passages in it which, as I have shown, owe their form or their very existence to the reporter and to no one else. It seems to me on the whole more likely that these echoes of the QI text were introduced into the Brudermord text-basis from memory than that consultation of the QI text itself-in manuscript or print-was a factor in the production of that text-basis. For the debt of the Brudermord to QI is mostly confined to a phrase or two scattered here and there throughout the play. Accordingly I have suggested as the most probable solution that the QI text was acted, presumably in the English provinces, before its publication, and that one or more of the players who compiled the text-basis of the Brudermord had taken part in it. In the Introduction we traced the establishment of the Orlando class of memorial reconstructions - that is, reconstructions made for acting in the provinces. It looks very much as if the first $Q$ uarto text of Hamlet was essentially a member of this class of text. And so is the Brudermord. 
Let me state briefly in conclusion the general hypothesis which I would advance to explain the condition of the QI text and its relationship to the authentic Shakespearian texts published later. The QI text post-dates these, and practically everything in it depends upon the full Shakespearian text of $Q_{2}$ or upon a stage version of that. ${ }^{x}$ It is a memorial reconstruction, made for provincial performance by an actor who had taken the part of Marcellus and perhaps another part or parts in the full play, and who was able, when his memory failed, to write blank verse of his own in which he often incorporated reminiscences and quotations of countless passages scattered throughout the full text. The only document to which he had access was the manuscript part of Voltemar, or a copy of that. The reporter's work was revised and to some extent amplified by himself or by a second agent (perhaps an actor too). In at least one particular (the position of the "nunnery" scene) QI represents an alteration of the texts published later in $\mathrm{Q}_{2}$ and $\mathrm{F}_{\mathrm{I}}$ : the reporter may himself have been responsible for this, or it may have appeared in a previous stage version of the $\mathrm{Q}_{2}$ text. At other points the reporter incorporated the phraseology and characteristics of the pre-Shakespearian Hamlet, for the existence of which there is good evidence: he may have done this deliberately or involuntarily. But the debt of the QI text to this old Hamlet is infinitesimal when compared with its debt to the $\mathrm{Q}_{2}$ text. Furthermore, QI does not represent the play as it stood at any stage, preShakespearian or Shakespearian, in its development: it is a conglomeration of elements from quite distinct versionsfrom the pre-Shakespearian play and from that given in $\mathrm{Q}_{2}$ - and for this conglomeration the reporter is entirely responsible. In short, while basing his text essentially upon that of $Q_{2}$, the $Q_{1}$ reporter has introduced both material

I But the reporter's knowledge extended beyond the $F_{I}$ text, since in $Q_{1}$ xii 3 there is a quotation from a line in IV iv omitted by $F_{I}$ as part of a theatrical cut.

$\mathrm{DB} Q$ 
274

THE FIRST QUARTO

from the old play and alterations of the final Shakespearian version. Finally, this conglomerate type of memorial reconstruction is exemplified in both the "bad" texts of Hamlet-that of the first Quarto and that of Der Bestrafte Brudermord. 


\section{INDEX}

Abridgment, 32, 34-5, 49 n. I, 53, $88,94,236$ n. 2,27 I- 2

Actors' names in stage directions, 6-8

Adams, J. Quincy, I4 n.I, 22, 24-5

Admiral's Men, 76

Albion's England (Warner), 80-1

Alexander, P., 37, 39, 4r-6

Allen, J. C., 86

Alleyn, Edward, 33

All's Well that Ends Well, 9 n.2, 220, 227

Alphonsus, Emperor of Germany, 1 92

Aminta (Tasso), 80

Anatomy of Absurdity (Nashe), 73

Anatomy of Abuses (Stubbes), 73

Antonio and Mellida, 7, 266

Arden of Feversham, II 3

Ariosto, see Supposes

Armin, Robert, 77 n. 3

"A.S." (stenographer), 2 I

Autographs, Shakespearian, 4-9,

3I, I 44

"Axiophilus", 81, 83

"Bad" Quartos, List of, I I n. I

Bales, Peter, 22 n. I, 24

Believe as you List, 6

Belleforest, 61, $19 \mathrm{I}-3,197-204$, $254,260,264$

Bernard, John, 36-7

Bibliographical links, between QI and $\mathrm{Q}_{2}$ Hamlet, 145-9; between $Q$ and $F$ Henry $V, 30-1$; between $Q_{1}$ and $Q_{2}$ Romeo ${ }^{\circ}$ Fuliet, $149 \mathrm{n} .2$

Boas, F. S., 43-4, 56, 65-70, 79$81,83,86,90,124,132,181$, 183 n., $184-6$, I96
Bond, R. Warwick, $45 \mathrm{n.2}$

Bowers, F. T., 192, I93 n. I

Brackets in Qr Hamlet, $145^{-8}$

Bradley, A. C., 194

Bright, Timothy, see Characterie Brudermord, Der Bestrafte, xi, I22 n.2, 161-2, 187-92, 200 ff., $218-20,225$ n. I, 238 ff., $271-2$, 274; Prologue, 253 n., 263-4

Bunbury, Sir Henry, 85

Burbadge, Richard, 235

Burleigh, Lord, 79, 224, 227

Cairncross, A. S., 263 n. I

Caldecott, 85

Capell, $2-3$, ro n. I

Carew, Richard, 80

Cecil, Sir Robert, 82-3, 224

Chambers, Sir E. K., 22, 45-6, 80,88 , II 7 n. $2,135,210,218$, 222, 227 n.I, 232 n.2, 235 n.2, $236,23^{8}$ n. $2,240,262$

Character-designations in "good" texts, 9

Characterie (Bright), $14,16 \mathrm{ff}$.

Civil Wars (Daniel), 8I

Clark, W. G., 86, 88, 132-3

Claudius, character of, $5^{\mathrm{I}-2}$

Clifford (in Henry VI), 44

Clutton-Brock, A., 191

Cohn, A., 238 n.1, 240 n.2, $25^{8} \mathrm{n} \cdot 2$

Collier, J. P., 87

Comedy of Errors, $A, 9$ n.2

I Contention, 3, 4 n.2, if n.I, $37 \mathrm{ff}$.

"Corambis", derivation of name, 223-4

Corbin, J., 86, 202, 239

Cornélie (Garnier, Kyd), 7r, 184 
Courthope, W. J., 40-I, 44

Cowley (actor), 7-8

Craig, Hardin, $46-7,86$

Creizenach, W., $38-9,45-6,87$, 92, 201-2, 222, 239-40, $25^{8}$, 262,264

Cunliffe, J. W., 64 n. 2

Daniel, Samuel, 8I

Davies, Sir John, 80

Dekker, Thomas, I I n. I, 77 n. I

Delius, N., 85

Dewischeit, C., I4 n. I, I6

Dictation, II, I6, 34

Donne, 80

Doran, M., 18 n. I, 23-5

Dowden, E., 86, $9 \mathrm{r}$

Drake, Sir Francis, 26r

Duenna, The, see Sheridan

Dyce, A., 85

Dyer, Sir Edward, 8o

Edward I (Peele), I I n. I

Egerton, $2 \mathrm{I}$

Elder Brother, The, 23

Eliot, Sir Thomas, 59

Elze, 85

"English Seneca", 55, 58, 61-2, 64 n. I

Erasmus, 59

Essex, Earl of, 80-I, 26r

Evans, M. Blakemore, 239, 265

Every Man in his Humour, 234

Every Man out of his Humour, 234

Exeter (in Henry V), 29-30, 32

Fair Em, Ir n. I

Fairfax, Edward, 80

Famous Victories of Henry $V$, The, II n. I

Fitzgerald, J. D., I 32, $^{2} 5^{2}, 2 I_{3}$

Fleay, F. G., 44 n.I

Förster, M., 14 n.r

Fortinbras, character and age of, 228-30
Foss, see Payne

Fraunce, Abraham, 8o

Friedrich, P., I4 n. I

Fruitful Sermon, $A$ (H. Smith), I9-20

Furnivall, F. J., 52, 86, 9r, 106, II $4,193-4,223,234,262-3$

Garnier, $7 \mathrm{I}$ n. I

Gascoigne, see Supposes

George a Greene, II n. I

Gericke, R., I 49 n. 2

Gerusalemme Liberata, 80

Gervinus, 85

Giordano-Orsini, G. N., I3, $32 \mathrm{n} . \mathrm{I}$

Gollancz, Sir I., 221, 223-4, 225 n. 2

Goslicius, Laurentius Grimalius, 224 n. 2

Governor of Harfleur (in Henry V), 29-3 I

Gower (in Henry $V$ ), 29-3r, $32 \mathrm{n}$. I

Granville-Barker, H., I33, 209ro

Gray, H. D., 7, 28-9, 77 n. 2, 87, 9r-2, I $37-40,142-3,225-6$, 264

Greene, Robert, 39-42, 55, 60, 69 Greg, W. W., IO, I2 n. I, I3, I 6 n. I, I 8 n. I, 22-3, 24 n. I, $27,32-3,37,47$, г16 n. 2, I 36 , I 39 n. 4, I 40, I 49 n. 2, I 80, 269

Grierson, Sir H. J. C., 79-81, 83 Groatsworth of Wit, A (Greene), 39

Groot, H. de, 86 n.2, I3I

Hamlet, character of, 52

Handwriting, Shakespeare's, 5

Harris (of Covent Garden Theatre), 35

Harrison, G. B., I4 n. I, 86

Harrison, W. A., 25

Hart, A., 53, 88, 27 I 
Hart, H. C., 27

Harvey, Gabriel, 78-84

Harvey, Henry, 82

Hatcher, O. L., 57

Heminge and Condell, $1,3-4$, ro Henry V, 93, 120, 256-7; "bad" Quarto, 2-4, $11,14-15,18-19$, $22,24,29,32,34-5,48,53$ n.2, I $20 \mathrm{n}$. I

2 E' 3 Henry VI, Ir n. I, 37 ff.

3 Henry VI, I1 2,257 n. $\mathrm{r}$

Henslowe, Philip, 76

Herford, C. H., $5^{\mathrm{I}-2}$, 86, $193-4$

Heywood, Thomas, 4 n. 2, I2-I 4 , 22

Hickson, S., 44 n. 1, 45-6

Historie of Hamblet, The, $6 \mathrm{I}$

Hjort, G., 149 n. 2

Hoppe, H. R., 5 I

Host (in Merry Wives), 27-8, I 39

Householders Philosophie, The (Tasso, Kyd), 67

Hubbard, F. G., 70 n.2, 86 n.2, I $3 \mathrm{I}$

Hubler, E., 22-3

Hughes (of Exeter Theatre), 36

Hunter, 85

I If You Know Not Me (Heywood), II n. I, 12, 22, 29, 32 n. I

Inverted commas in Qr Hamlet, I 6,145

I Suppositi, see Supposes

Jack, A. E., 57-9, 6i-3, 64 n. 2 , 66,67 n. $2,68,70$ n. 2,71 n. 2 , 72,75

I Feronimo, 182,263 n. I

Johnson, Samuel, 2

Juvenal, 223 n. $3,267-8$

Kemp, William, 7-8, 225-7, 234-6

"Kid in Aesop, The", 55-6, 65, 7 I 6
King Fohn, 128

King Lear Q1, Ir n. I, 22-6

Kirschbaum, L., II n.I

Knack to Know a Knave, $A, 225$

Knack to Knorw an Honest Man, $A$, II n. I

Knight, Charles, 85

Koeppel, 70-1, 75

Kyd, Thomas, $x, 43,56 \mathrm{ff}$., 90-I, I8r ff., 196, 264-5

Latham, R. G., 239 n. 3, 26r, 267

Lawrence, W. J., 86

Lee, A. C., 77 n. 3

Lee, Sir Sidney, 79-80

Lewis, C. M., 239

Lodge, Thomas, 76-7

Love's Labour's Lost, 9 n. 2

Lucianus (in Hamlet), 29, 87, I40

MacCallum, M. W., 67 n.6, 69, $7 \mathrm{I} \mathrm{n.2}$

MacDonald, G., 86

McKerrow, R. B., 6-9, 66-70, $72-3,75$

Maid's Tragedy, $A$, I I n.I

Malone, Edmond, 3, ro n. I, 37$4 \mathrm{r}, 43-4,78-80$

Marcellus (in Hamlet), 28, 87, I 37-40, 273

Marlowe, 4r, 44 n. I, 57

Mar-Prelate pamphleteers, 59-60

Massacre at Paris, The (Marlowe), in n.I

Matthews, W., I6, 19-21, 22 n. I

Melanchthon, 59

Menaphon (Greene), 55, 262

Merchant of Venice, The, 9 n.2

Meres, Francis, 83 n. 3

Merry Wives of Windsor, The, Quarto, 2-4, II I I , 19, 22, 24, 27, 34, 47, I 39-40; Folio, 9 n. 3 Midsummer Night's Dream, $A$, $9 \mathrm{n} .2$

Mishearing, I6 
Mislineation, $19,22-3,139,156$

Mommsen, Tycho, 4 n. 2, 26, 28 , $38,42-3,51,87,92,140$

Moore Smith, G. C., 78, 8I

More, Sir Thomas, 5

More, Sir Thomas, 59

Morgan, Appleton, 262

Mountjoy, Lord, 8r

Much Ado About Nothing, 7, 226

Murder of Fohn Brewen, The (Kyd), 184

Nashe, Thomas, 55 ff., $191,262-3$ Nest of Ninnies (Armin), 77 n. 3 Never Too Late (Greene), 42

Nicholson, Brinsley, 48-50, 234Nine Days' Wonder (Kemp), 234 Norris, 26I

Olla Potrida, 238

Omission in "bad" texts, 50, $52-3,272$

Orlando Furioso (Greene), II n. I, $32-4,37,44-5,47,236,258,272$

Ostend, English defence of ( $160 \mathrm{I}-$ 2), 84

$\emptyset$ sterberg, V., 57, 73-5, 88, 230-I

Othello, 3 n.2, 227

Owen, John, 79

Palladis Tamia, see Meres

Parrott, T. M., 86

Parts, actors', 2, II , I3, 28-32, $34, \mathrm{I}_{34-5}, \mathrm{I}_{39}, 204,273$

Payne and Foss, 85

Peele, George, 39-4I, 57

Pembroke's Men, 4I

Percy, Bishop, 78-9

Pericles, II n. I

Philaster, II n. I

Plantine, 59

Player-Duke (in Qr Hamlet), 27

Pleasant Dialogues and Drammas (Heywood), I2
Poel, W., 88, 209, 2 I 8

Pollard, A. W., I, 4-6, 8-9, Ir, I $3,25-6,43$

"Polonius", derivation of name, 224 n. 2

Pope, I

Portugal (Brudermord), 26I-3

Preston, Thomas, 82

Price, H. T., 14 n. $1,{ }_{5}, I_{8-20}$, 29-3I

Prompt-copy, 4, 6-II, 3I, 34, I $34-5,222,236,25^{8}$

Provinces, performances in, $\mathrm{II}$, $33-5,37,44-5,88,222,225$, $236, .25^{8}-9,269,272$

Punctuation, 23, 30 n. 3, 3r, I 35

Queen's Men, The, 33

Quiller-Couch, Sir A., 44 n. I

Raleigh, Sir W., 80

Ramello, G., 88, 140, 142, I79, 200, 203

Rape of Lucrece, The (Heywood), I 2

Reichard, H. A. O., $2{ }_{3} 8$

Reporting, definition of, ro

Return from Parnassus, The, 234

Rhodes, R. Crompton, $34-7,88$, II, $227-3$ I, 27 I

Richard II (Parliament Scene), II n. I, 25-6

Richard III, I I n. I, I 86

Ridley, M. R., 45, 89

Robertson, J. M., 43-4, 86, II 3 , I 8 r, I84-6, I93-4, I96

Romeo \& Fuliet, Q I, 3-4, I I, I4, I9, 22, 34, 38, 42, 51; Q2, 9, 149, 225

Roscius (Brudermord), 267; (Greene), 42

Sadolet, 59

Salmon, D., 20 
Sarrazin, G., 56-7, 65-6, 68, 70$2,75,181,196,264$

Satiromastix (Dekker), 77

Saxo Grammaticus, 191, 224, 254

Schick, 65, 68, 70

School for Scandal, The, see Sheridan

Schottner, A., I4 n.. I

Seneca, 55, 58, 6I-5

Shepherd's Calendar, The, 72

Sheridan, piracy of, $35-7$

Singer, 85

Smart, J. S., 37, 39, 4r, 45

Smith, Henry, I9

Soliman and Perseda, r 86 n. 2

Spanish Tragedy, The, 66, 68-71,

77 n. 3 , I $13,124,182$ ff., I 96 , I $99,203,265-6$

Speght, 78,83

Spenser, 72, 74, 78-9

Staunton, 85

Stenography, 2, 4 n.2, roff., 34, 87-8

Stoll, E. E., 86, 205 n. 2, 2 10

Stopes, Mrs C. C., $5^{8}$ n. 2 , 6 r

Strange's Men, Lord, 33, 4I

Stubbes, Philip, 73

Suffolk (in Henry VI), 44

Supposes, 46

Swinburne, 86

Taming of a Shrew, The, 3, II n. I, 44 n. I, 45-7

Taming of the Shrew, The, 45-7

Tanger, G., 88, r6on., I62, 207-

9, 2 10 n. I, 21 7-I 8, 220-I, 239 , 253

Tarlton, Richard, 232-4

Tarlton's Fest Book, 232-3, 236

Tasso, 67, 80

Ten Brink, B., 46-7

Theater-Kalender (Gotha), 238
Theobald, 2

Thompson, Sir E. M., 5

Thorndike, A. H., 239

Timmins, 85

Titus Andronicus, 9 n. 2 , 128

Troublesome Raigne of Fohn, King of England, The, 2, 3 n. I

True Tragedy of Richard Duke of rork, The, 3, 4 n.2, II n.1, $37 \mathrm{ff}$.

True Tragedy of Richard III, The, II n. I

Turner, William, 64

Twelfth Night, I 15

Two Gentlemen of Verona, The, 9 n. 3

Trwo Noble Kinsmen, The, 6

Van Dam, B. A. P., I5, 45, 88, 221

Van Norden, L., 9I

Voltemar (in QI Hamlet), 26-7, $1_{34}, 1_{3} 6,204$

Warner, William, 8I

Warning for Fair Women, A, 266

Wars of the Theatres, 84

Warwick (in Henry VI), 44

Watson, Thomas, 79

Westenholz, F. P. von, 88, I $3 \mathrm{r}$

White, R. G., 40, 88, 208, 2 10, 217

Widgery, W. H., 26-7, 86, 134, I8 I, 186, 196, $212 \mathrm{n}$.

Wild Goose Chase, 6

Wilkinson, Tate, 35,37

Willis, John, 22, 26

Wilson, J. Dover, 5, 8 n. 2, 45, 75 , 84 n. I , 86, 94 n. I, I I 5, I $3 \mathrm{I}-2$, I $34, I_{35}$ n. $3, r_{3} 6, r_{3} 8-9$, I $44-$ $50,176,195,222$ n. $3,232-3$

Wright, W. Aldis, 86, 89, $\mathrm{I}_{32-3}$

Wyatt, Sir Thomas, II n. I

CAMBRIDGE: PRINTED BY W. LEWIS, M.A., AT THE UNIVERSITY PRESS 